RONALD DE FIGUEIREDO E ALBUQUERQUE

\title{
A IGREJA CATÓLICA NO PROCESSO DE FORMAÇÃO DA CLASSE TRABALHADORA
}

Tese apresentada à Banca Examinadora da Universidade Federal do Ceará, como exigência parcial para obtenção do título de Doutor em Educação Brasileira, sob orientação da Professora Dra. Sonia Pereira Barreto.

Fortaleza

2012 


\section{A IGREJA CATÓLICA NO PROCESSO DE FORMAÇÃO DA CLASSE TRABALHADORA}

Esta Tese foi submetida como parte dos requisitos necessários á obtenção do título de Doutor em Educação Brasileira, pela Universidade Federal do Ceará - UFC, aprovada no dia 16/08/2012.

Dr ${ }^{\mathrm{a}}$. Bernadete Beserra

Dr. Cesar Baneira

Dra . Eliane Dayse

Dr. Geovane Jacó

Dr. Jouberth Max Maranhão

Dr. Piorsky Aires

Drª . Sônia Pereira Barreto (orientadora) 
Aos meus filhos e às minhas netas, Inaiê, Dandara e Cecília, rebentos que nasceram durante os cinco anos de esforço concentrado, alegrando a vida com suas graças e brincadeiras. São elas que me alegram e suavizam a vida. 


\section{AGRADECIMENTOS}

Finalmente conclui este trabalho. Foram cinco anos, um ano a mais do que o tempo regulamentar. Minha esposa, Maria da Conceição, e eu receávamos não chegar a termo nesse trabalho que me propunha realizar, foram muitos percalços, mas com ela, juntos, conseguimos superar e estamos agora nesse momento colhendo o resultado, para nós, eu e ela, suficiente, conseguimos no percurso enxergar um pouco mais.

Agradeço a Sônia, minha orientadora, pessoa que com sua calma e segurança pôde conduzir o processo de realização deste trabalho ao final. Não sei se o trabalho consegue satisfazê-la completamente, mas acredito que ela concorda sobre a importância de se voltar o olhar sobre as Comunidades Eclesiais de Base, principalmente as de Crateús, que por sua precocidade e destemor, conviveram muito proximamente da repressão e da prepotência dos militares do Batalhão de Engenharia situado em Crateús.

À Emanuel e Kátia agradeço o carinho e cuidado que sempre me devotaram. Foram eles que estiveram sempre me incentivando ao longo desse curso de doutorado para que não recuasse diante das dificuldades que encontrei no meu caminho. Agradeço a Sergio a disponibilidade e a paciência com que sempre me recebeu na secretaria do doutorado, mesmo quando vinha com os prazos apertados.

Ao longo do período conheci pessoas com as quais pude conviver e aprender a gostar pela disponibilidade que demonstraram ao relatar a história das Comunidades Eclesiais de Base de Crateús, e a história de D. Fragoso. Como gostaria de ter conhecido padre tão dedicado e tão voltado para os problemas que afligia os pobres. No seu voltar-se para os segmentos mais pobres da sociedade, para os trabalhadores, não se encontrava nenhum resquício de "piedade", entre aspas, mas sem nenhuma intenção de menosprezar a piedade; quero apenas chamar a atenção para 
uma palavra gasta ao longo do tempo, mas apenas a certeza de que para eles, por tudo que são, a sociedade deve humanidade.

Portanto, agradeço primeiro a Eunice. Ex-freira, hoje assentada, que, sem me conhecer, colocou-se à minha disposição, apresentando pessoas, conseguindo documentos, sempre disposta a conversar atendendo a minha curiosidade. Ao pessoal do Instituto D. Fragoso que sentou comigo para papearmos sobre D. Fragoso, as Comunidades, os sindicatos e os personagens, padres e leigos, que se propuseram a fazer história.

Agradeço também ao pessoal do Assentamento de Palmares, ao casal Luis Antonio e Maria de Jesus, juntos na vida, mas que ao longo do movimento sindical estiveram em campos às vezes opostos. Agradeço, também, a Tchesca que me disponibilizou documentos e o seu trabalho sobre o processo educacional nas CEBs. Manuel e Ariosvaldo, dirigentes sindicais, juntamente com seu Enoque, também alunos meus no curso de Licenciatura do Campo, curso ministrado pela Universidade Regional do Cariri. Agradeço a todos, inclusive aos padres Machado, Eliésio, falecido recentemente, Elênio, Maurízio, Osmar. Este último, companheiro das lutas no Cariri quando era assessor da Delegacia da FETRAECE para o Cariri. Hoje padre em Ipueiras, possibilitou minha conversa com Pe. Eliésio.

Gostaria de agradecer a Banca, constituída dos professores Max Maranhão, Eliane Deisy, Bernadete Beserra e Cesar Barreira, que com cuidado examinaram o trabalho em apreço apontando as deficiências para as devidas correções. Por fim, agradeço de modo especial ao professor Gil Jacó que sendo rigoroso não deixou de apontar possibilidades e indicar soluções para algumas questões, melhorando sensivelmente o trabalho final. Os erros que persistirem são fruto da minha teimosia.

Agradeço, ainda, à minha cunhada, Simone, por nos ajudar a enfrentar os percalços que enfrentamos nesses cinco anos. Finalmente, agradeço a todos que de uma maneira ou de outra contribuíram para que eu realizasse 
esse trabalho. Não sei se esta Tese vai contentá-los como a mim, afinal pude conhecer, mesmo que não completamente, o processo de construção dos trabalhadores rurais de Crateús como sujeitos da história. Essa construção é inacabada, mas as bases estão consolidadas. 


\section{RESUMO}

O presente trabalho expõe o processo pelo qual passou a Igreja Católica ao voltar-se para a sociedade e nela comprometer-se com os mais pobres. Sua inserção entre os segmentos populares propiciou a organização desses, ao mesmo tempo, que permitiu refletir sobre a ação da Igreja Católica. Essa reflexão mudou a práxis política de religiosos e leigos que passaram a ver a Igreja como instrumento privilegiado de mudança social e política, já que ela é uma instituição presente em todos os recantos conformando a população de modo geral. Relevo também, o papel dos segmentos populares, que não apenas sofrem a ação da Igreja, mas que exercem sobre ela um papel crítico, capaz de contaminar setores da Igreja Católica, fazendo-os rever posições e definir ações mais pertinentes com a realidade dos segmentos populares. Nesse trabalho, analiso do percurso da igreja Católica no Brasil, quando, paulatinamente, alguns segmentos de sua hierarquia vão se inserindo nas lutas do povo, revelando os processos de dominação e submissão em vigor, forçando uma tomada de posição da Igreja que acaba por repercutir no Vaticano II. A partir dele abre a Igreja para sua inserção histórica comprometida com os pobres, é a Igreja dos pobres como bem define a Teologia da Libertação e que se faz presente na organização das Comunidades Eclesiais de Base. Friso que as comunidades se colocam de forma mais expressiva e política principalmente, a partir, dos anos da ditadura militar. Essa peculiaridade faz com que alguns intelectuais acreditem que a presença política das comunidades é uma consequência do fechamento dos espaços políticos formais, sindicatos e partidos políticos. A tese que defendo, a partir da Diocese de Crateús, é que são espaços de encontro, e por serem espaços de encontro se transformam em espaços de inserção social e política que a Igreja vem assumindo desde os anos de 1950. Crateús é uma demonstração clara de que as comunidades são espaço de encontro e, por isso mesmo, políticos, espaços da fala ativa e crítica em função de uma Igreja que se coloca aberta à fala do povo, estimulando-o à participação nas ações definidas nas Comunidades. São as 
CEBs, em função disso, espaços de educação política que ainda hoje repercute na ação dos segmentos populares. A metodologia utilizada foi contato direto com os trabalhadores, que participaram de CEBs, com a Igreja, padres, religiosas, agentes de pastoral, coordenadores e sindicalistas, através de entrevistas individuais e coletivas, da análise de documentos escritos e livros, da participação em reuniões e visitas a algumas instituições criadas a partir da ação dos membros das CEBs.

Palavras chaves: Igreja Católica; Teologia da Libertação; Comunidades Eclesiais de Base; Sujeito Histórico; Política. 


\section{ABSTRACT}

The present work describes the process by which the Catholic Church turns its attention to society and commits itself to the poorest. This commitment helped organize the popular segments, while at the same time, it allowed a reflection on the action of the Catholic Church itself. This reflection has changed the political praxis of religious and lay people who came to see the Church as a privileged instrument of social and political change, since it is an institution present in every corner shaping the population in general. I stress also, the role of popular segments, which not only suffer the action of the Church, but exert back on it a critical role, capable of influencing sectors of the Catholic Church, causing them to review positions and define actions more relevant to the reality of the popular segments. In this work, I analyze the trajectory of the Catholic Church in Brazil, when, gradually, some segments of its hierarchy take part in the struggles of the people, revealing the processes of domination and submission in place, forcing an official position of the Church that ultimately impacts Vatican II. Afterwards, the Church, historically, becomes committed to the poor--it is the Church of the poor, as well defines the liberation theology. This commitment leads to the organization of the Basic Ecclesial Communities (BECs). These communities become more expressive politically, primarily, from the years of military dictatorship. This peculiarity makes some scholars believe that the political presence of the CEBs is a consequence of the closure of formal political spaces such as unions and political parties. The thesis that I defend, based on studies of the Diocese of Crateús, is that the BECs are meeting spaces that are transformed into spaces of social and political activities that the Church has taken control of since the 1950s. Crateús is a clear demonstration that communities are gathering spaces and, therefore, political spaces of active and critical speech in a church that stands open to talking to the people, encouraging them to participate in the actions defined in the communities. BECs are, as a result, spaces of political education that still reverberate in the action of popular strata. The methodology used was based on direct contact with the workers who participated in BECs with the 
Church, priests, nuns, pastoral workers, union members and coordinators, through individual and group interviews, analysis of documents and books, participation in meetings and visits to some institutions created through the action of BEC members.

Keywords: Catholic Church; Liberation Theology; Basic Ecclesial Communities; Historical Subject; Politics. 


\section{LISTA DE SIGLAS E ABREVIATURAS}

ACO - Associação Católica Operária

ANCAR - Associação Nacional de Crédito e Assistência Rural

CEB - Comunidades Eclesiais de Base

CNBB - Conferência Nacional dos Bispos do Brasil

CONTAG - Confederação Nacional dos Trabalhadores na Agricultura

CPT - Comissão Pastoral da Terra

ELERUR - Escola de Líderes Rurais

FALTAC - Federação dos Agricultores, Lavradores e Trabalhadores Agrícolas do Ceará

FETRAECE - Federação dos Trabalhadores Agrícolas do Estado do Ceará.

FPI - Fundação Padre Ibiapina

LEC - Liga Eleitoral Católica

AC - Ação Católica

JUC - Juventude Universitária Católica

JEC - Juventude Estudantil Católica

JOC - Juventude Operária Católica

JAC - Juventude Agrícola Católica

ACO - Ação Católica Operária

PC DO B - Partido Comunista do Brasil

PCB - Partido Comunista Brasileiro

PT - Partido dos Trabalhadores

MDB - Movimento Democrático Brasileiro

MST - Movimento dos Sem-terra

PMDB - Partido do Movimento Democrático Brasileiro

STR - Sindicato dos Trabalhadores Rurais 


\section{SUMÁRIO}

INTRODUÇÃO

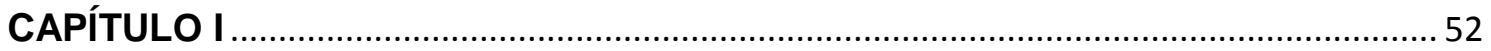

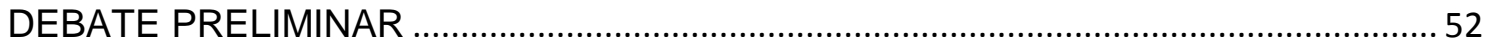

1.1. Trabalhadores rurais e Igreja, as razões da minha escolha ....................... 52

1.2. A Diocese do Crato e o Sindicato de Trabalhadores Rurais. ..................... 54

1.3. Crateús, a Igreja Progressista e os Trabalhadores..............................................60

1.4. As Comunidades Eclesiais de Base: uma nova forma de inserção política da

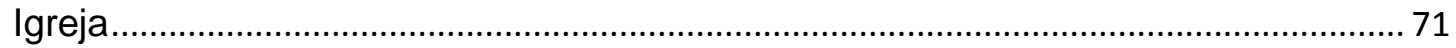

1.5 Igreja, CEBs e Sindicatos dos Trabalhadores do Campo ....................................... 84

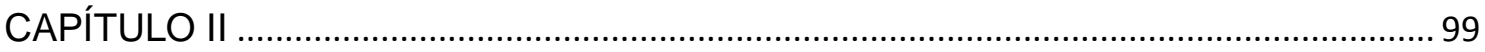

DESENVOLVIMENTO DE COMUNIDADES E RENOVAÇÃO DA IGREJA................ 99

2.1. A Ação Modernizadora da Igreja Católica.................................................... 107

2.2. A Inserção da Igreja na Sociedade: construindo uma nova Igreja .......... 115

2.3. Os Leigos da Ação Católica Especializada ................................................... 121

2.4. O Movimento de Educação de Base e os Camponeses................................. 131

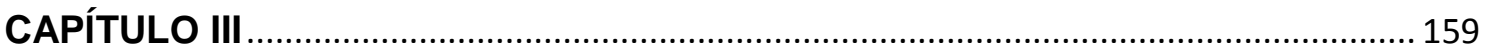

D. FRAGOSO E O PROCESSO DE CONSTRUÇÃO DOS NOVOS SUJEITOS DA

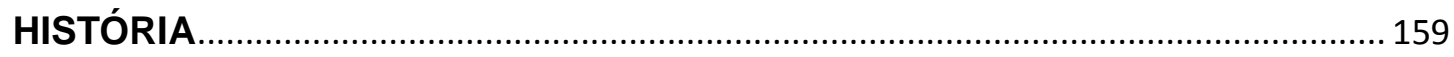

3.1. D. Fragoso e a Igreja Católica Progressista .................................................. 170

3.2. D. Fragoso chega à Crateús e Afirma Compromisso da Igreja com os Pobres177

3.3. Construindo uma Nova Forma de Ser Igreja ............................................... 185

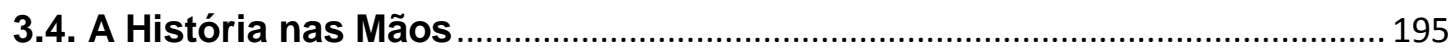

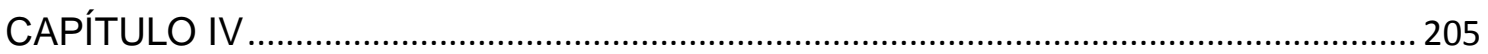

AS COMUNIDADES ECLESIAIS DE BASE E A POLÍTICA EM CRATEÚS ............. 205

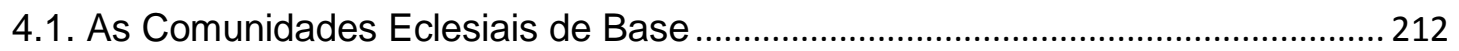

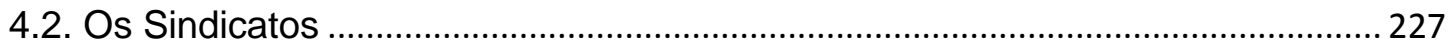

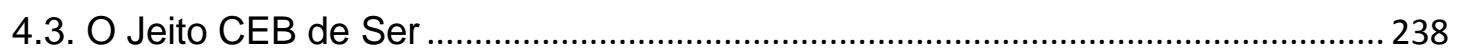

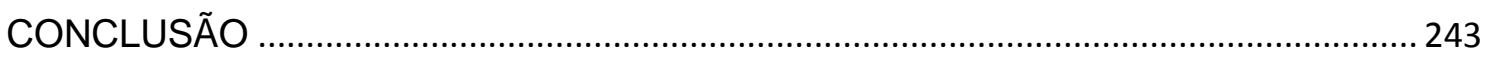

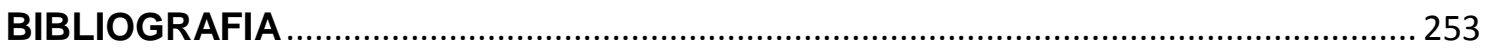

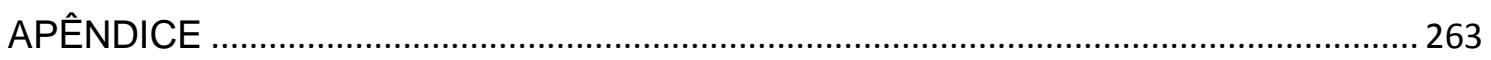




\section{INTRODUÇÃO}

O presente trabalho é uma investigação acerca do papel da Igreja Católica no processo de formação da classe trabalhadora a partir dos anos setenta, do século XX, enfocando a ação das Comunidades Eclesiais de Base e dos religiosos ligados à Teologia da Libertação, com o intuito de apreender suas possibilidades educativas político-transformadoras.

Escolhi como objeto de trabalho a Diocese de Crateús ${ }^{1}$. O motivo da escolha é a repercussão que o trabalho de CEBs de D. Fragoso, primeiro Bispo Diocesano de Crateús, diocese criada em 1964, na linha da libertação, teve nacionalmente e, depois por ser essa Diocese majoritariamente rural. Como diz Libânio: "Essas novas linhas, ainda fazendo parte dos desejos do que da realidade, tinham sido, de certo modo, antecipados na experiência de Crateús." (LIBÂNIO, 2005)

É conveniente lembrar que a ação dos religiosos que trabalhavam com a organização das Comunidades Eclesiais de Base em suas dioceses se dava em dois sentidos: na modificação da concepção do Ser Igreja e, a partir dessa visão, uma ação sobre a sociedade que comportasse a construção de uma nova sociedade com base nos novos princípios da Igreja reconstituída.

Essa minha preocupação com os trabalhadores e pequenos produtores rurais decorre, primeiro, de uma leitura de Marx e do marxismo, que priorizam os trabalhadores urbanos, o proletariado, desprovido dos meios de produção e, portanto, são obrigados a vender a força de trabalho ao capitalista para assim suprir, via mercado, as suas necessidades básicas. Em segundo lugar, decorre, também, da minha prática política voltada para a organização dos trabalhadores e pequenos produtores rurais. Acredito que estes são capazes de construir sua história e perceber-se, como o proletariado urbano, como classe espoliada pelo capital que se apropria do

\footnotetext{
${ }^{1}$ A Diocese de Crateús compreende treze municípios: Nova Russas, Ipueiras, Poranga, Ipaporanga, Ararendá, Tauá, Parambu, Quiterianópolis, Crateús, Tamboril, Mons. Tabosa, Independência e Novo Oriente (Alder Júlio. As Comunidades Eclesiais de Base. In Fragoso, D. Antonio. Igreja de Crateús.
} 
seu excedente. Deles pode partir a iniciativa transformadora que, inclusive, contamine as outras classes sociais.

A ação da Igreja de Crateús é também educativa, como é educativa qualquer ação que implique numa percepção ampliada da realidade. Primeiro, como a Ação Católica, usou o método Ver, Julgar e Agir, em que os agentes tendiam a desvelar a realidade num processo dialogal com o intuito de uma práxis transformadora. Essa práxis se radicaliza num segundo momento com as CEBs, que se apropria do método de Paulo Freire, como revela Frei Beto em diálogo com Freire, em entrevista simultânea cedida ao jornalista Ricardo Kotscho (KOTSCHO, 1986).

O marco teórico que será utilizado, como consequência, para a apreensão do objeto acima determinado, será o materialismo histórico. Isto, porque, acredito, como Löwy (1994), que esta concepção de conhecimento possibilita uma visão não apenas mais ampla como também mais profunda da realidade ao pôr em evidência as contradições do capitalismo. No caso presente as contradições que emergem do desenvolvimento do capitalismo que usa o pequeno produtor como produtor de excedentes para o capital, sem, no entanto, espoliá-lo dos meios de produção, como faz com o proletariado.

Nesse modo de produção, como nos ensina Marx, existe duas classes fundamentais: burguesia e proletariado. A primeira contém os proprietários dos meios de produção e a segunda agrega os desprovidos dos meios de produção. Mas, essa visão não exclui outros segmentos sociais que de maneira diferente são também submetidos à lógica do capital, como os camponeses de diversos matizes ${ }^{2}$ (MARTINS, 1986). Os interesses, portanto, são antagônicos provocando conflitos que implicam no processo de organização sindical e política dos trabalhadores, tornando-os conscientes

\footnotetext{
${ }^{2}$ Quando me refiro aos camponeses o faço a partir da leitura que dele faz Martins (1995). Para esse autor, a categoria camponês apreende as características mais gerais, unificando os diversos segmentos do homem do campo (pequenos produtores, parceiros, moradores, posseiros) que trabalham a terra com sua família, produzindo alimentos para sua manutenção e, só esporadicamente, comercializando os excedentes.
} 
da necessidade de superação deste modo de produção econômico e de suas representações justificadoras da exploração e espoliação dos trabalhadores.

No Cariri, até os anos cinquenta do século passado, os trabalhadores e pequenos produtores rurais viviam espalhados, sem contatos, a não ser aqueles mediados pelos proprietários das terras, seus patrões, ou pela Igreja Católica, nas festas religiosas. Em tempos normais, a dependência dos agricultores era tal que inviabilizava qualquer processo de organização que pusesse em questão as relações de dominação e a necessidade de transformá-las. Apenas nas condições de expulso da terra, como aconteceu com os posseiros de Parambu, a reação acontecia como iniciativa dos camponeses.

Assim, muitas vezes, na maioria das vezes quando era quebrada a normalidade das relações em função do desenvolvimento do capitalismo, a sua organização somente poderia ocorrer através de um processo de intervenção externo. Não quero com isso afirmar que Lênin (1979, p. 24) ao analisar as relações de produção capitalistas, na Rússia, tinha razão quando dizia que os trabalhadores, envolvidos no processo de trabalho, eram incapazes de ir além da luta econômica, necessitando, portanto, da intervenção política dos intelectuais.

A forma de organização dos pequenos produtores rurais, com base no trabalho familiar, dificultava a interação entre os membros dessa categoria social. Como proprietários dos seus meios de produção, não sentiam a relação de exploração presente entre os assalariados (MARX, 1976, p. 22).

Assim, a organização desse segmento dependeria, naquele momento, da ação de instituições externas como os partidos políticos, sindicatos e a Igreja Católica. Em função de suas relações históricas com as classes dominantes a ação da Igreja Católica se torna mais fácil. Portanto, não encontraria 
resistência como aquela que encontraram as Ligas Camponesas e o Partido Comunista (MARTINS, 1995, p. 82).

Quando da elaboração da minha dissertação de mestrado, no início dos anos oitenta do século próximo passado, uma questão, no entanto, me inquietava: qual o interesse da Igreja Católica com a organização dos sindicatos? Por que ela, temerosa às revoluções e aos movimentos sociais, fundou sindicatos rurais?

Sabia apenas que ela, nas décadas de cinquenta e sessenta do séc. $X X$ havia criado vários sindicatos rurais. Como, me perguntava na ocasião, se era ela um instrumento de dominação a serviço da classe dominante? E, instigado por estas indagações, fui procurar as razões desse envolvimento.

Minha dissertação de mestrado traz todo o resultado desta pesquisa e minhas conclusões, concordando com Follmann (1985), apontam na direção de que a Igreja não é absolutamente conservadora e nem absolutamente progressista. É uma instituição social e, como tal, perpassada pelas contradições que existem na sociedade.

Nas décadas de cinquenta e sessenta do século passado, na Igreja, em função da correlação de forças internas, predominava a posição conservadora, mas o seu conservadorismo permitiu, nacionalmente, uma intromissão social que, para o Brasil, foi progressista.

Maduro (1983), por exemplo, é categórico em afirmar que a Igreja é dinâmica e multifacetada. A Igreja é uma instituição múltipla que se reproduz e é reproduzida num contexto social e não fora dele, apesar de ultrapassar os limites de um país ou de uma sociedade.

Nesta dinâmica, a Igreja organiza os sindicatos para diminuir os espaços das esquerdas. No seu processo de formação, porém, foram levantadas algumas bandeiras, que não se apresentavam com clareza no horizonte dos 
trabalhadores rurais do Cariri, como a reforma agrária, os direitos trabalhistas, dentre outras. Estas reivindicações criaram um clima de mobilização intensificado com a ditadura, motivando, inclusive, a repressão. Com a repressão alguns religiosos são perseguidos, fazendo com que segmentos expressivos da lgreja reagissem e entrassem em confronto com os militares no poder. Neste momento começou o trabalho de CEB e das pastorais.

Tal processo de radicalização, inclusive respaldado pelo Concílio Vaticano II (COMBLIN, 1996, p. 32), fez aparecer toda uma reflexão teológica que compromete cada vez mais o catolicismo no Brasil com as lutas democráticas e com a organização revolucionária dos segmentos excluídos, excluídos dos direitos sociais, políticos e jurídicos (MARTINS, 1984, p. 105).

Com a redemocratização do país e com as mudanças que ocorreram na Igreja, na década de 1980, a evidência político-social da Igreja parece diminuir. Ela parece não mais atuar na mesma dimensão das décadas anteriores. Segundo Perani (1990), este retraimento da Igreja era justificado pelo aparecimento de novos canais de expressão popular, como os partidos políticos e o novo sindicalismo. Para Comblin (1996), no entanto, foi a ação do Vaticano que interferiu nas dioceses, nas ordens religiosas, cerceando a ação dos padres chamados de progressistas. Mas, será que por si só esses elementos seriam responsáveis pelo aparente refluxo da ação progressista da Igreja? Não haveria outros elementos explicativos para este fenômeno?

Se olharmos para a Ação Católica nos anos de 1950, vemos sua inserção entre os universitários, os secundaristas e os operários. Depois, entre os trabalhadores rurais levantando as bandeiras da reforma agrária e da ampliação dos seus direitos trabalhistas. Mas, com os marginalizados, sua ação era assistencial, sem a pretensão de incluí-los num processo de organização política. Naqueles anos, o contingente de excluídos também não era tão significativo como hoje, o que havia era um processo de migração em direção aos centros urbanos que preocupava a Igreja Católica. 
Após 1964, com o desaparecimento das liberdades políticas, a Igreja passa a ser, segundo as análises até aqui verificadas, o grande canal da organização política. Talvez, substituindo os partidos extintos e postos na ilegalidade. Depois, já nos anos de 1990, com a nova realidade inaugurada com o neoliberalismo da era Collor, sua preocupação se volta, prioritariamente, para os marginalizados e excluídos que se multiplicam nos espaços urbanos ${ }^{3}$. A luta das associações sindicais restringe-se à garantia do emprego, os desempregados não são acompanhados, a estrutura sindical não o permite, cresce a miséria e a marginalidade.

Neste sentido questiono se a mudança da realidade política brasileira, com a adoção do modelo neoliberal, não teria, também, uma parcela de responsabilidade sobre as mudanças, aparentes, da ação da ala progressista do catolicismo no país. Afinal, o movimento sindical é impactado. Com o desenvolvimento tecnológico, são fechados postos de trabalho, há reformulação do Estado, com o esvaziamento de algumas de suas atribuições, terceirização dos serviços, etc. (LESBAUPIN, 1996; p. 11).

Além dessas, algumas situações indicam outras barreiras à ação organizativa dos trabalhadores a partir da ação da Igreja, como o aumento dos excluídos. Os partidos e sindicatos parecem não saber como lidar com os marginalizados (PERANI, 1990). São instituições voltadas para os incluídos institucionais como os trabalhadores formais e cidadãos plenos, ou seja: aqueles que têm emprego e inserção produtiva na sociedade.

Dessa forma, a Igreja Católica é chamada a atuar entre estes segmentos, talvez a partir de uma postura tradicional assentada na piedade cristã, sem os questionamentos próprios à sua fase libertadora, já que não pode

\footnotetext{
${ }^{3}$ Perani justifica o foco nos mais pobres e marginalizados como uma opção provocada pelo retorno dos partidos à legalidade. Para ele também os sindicatos passam a gozar de maior autonomia. As lutas encontram então os seus canais de expressão. Mas, sobra sem canal e sem expressão os marginalizados, os moradores de rua, os desempregados, as prostitutas etc. Justifica-se assim a opção da Igreja no final dos anos de 1980. (PERANI. 1990)
} 
considerar os excluídos como sujeitos históricos, a fala marxista voltada para o proletariado, para o operariado, marcava ainda sua visão de história. . Mas sua atuação com os excluídos, a partir dessa perspectiva, repercute na sua ação sindical e política, mesmo que ainda atuando nos movimentos sociais a partir das pastorais. Mas sua radicalidade, sua visão transformadora e crítica com relação ao capitalismo, não são mais as mesmas.

A análise da atuação da Igreja Católica junto aos segmentos populares não deve ficar apenas entre os que fazem parte de sua hierarquia, padres e bispos. Mas, também, junto aos leigos que participaram da ação católica especializada e das comunidades eclesiais de base, ou seja, a população sobre a qual recaía a sua ação pastoral.

Neste trabalho, verifico, também, se a população atingida pela ação da Igreja, através das Comunidades Eclesiais de Base, mudou sua inserção na sociedade civil, deixou de ser política para ser assistencial. Até que ponto deu continuidade a sua participação política, inserindo-se em outros tipos de organização, cobrando mudanças substanciais nas estruturas de poder vigente. Afinal, os novos sujeitos das falas de Martins (1984) e Sader (1995) não se colocam como sujeitos apenas enquanto membros das CEBs; sua postura política deve ter se ampliado, sua necessidade de mudança deve ter se expressado através dos instrumentos político-partidários e sindicais, pelo menos assim aconteceu em Crateús como o afirmam os entrevistados citados adiante.

Sader, em seu livro clássico, vai afirmar que os novos espaços políticos e os novos sujeitos são uma aparição decorrente do fechamento dos espaços institucionais, abertos novamente, deslocariam, em parte, sua atividade política para esses canais institucionais, aliviando a Igreja da pressão política a que estava submetida.

Do mesmo modo, avalio a inserção desses segmentos dentro da instituição Igreja Católica. Afinal, a Teologia da Libertação enquanto nova compreensão 
do ser Igreja e das Comunidades Eclesiais de Base, enquanto forma de organização social e política, não pode ter desaparecido. Talvez, o trabalho contra-hegemônico ocorra na organização dos excluídos, organização que pode resultar numa compreensão mais ampla do modo de produção capitalista, de suas contradições e limites. A compreensão da luta de classes ganharia uma dimensão maior do que a afirmada pela ortodoxia marxista. Não seria apenas os trabalhadores formais, urbanos e industriais, 0 segmento responsável pela a revolução. Para mim, parece ser essa a compreensão de Gramsci ao trabalhar com o conceito de hegemonia. Nessa direção caminham também as análises de Martins (1984) e de Sader (1995). O primeiro quando faz sua reflexão sobre as categorias rurais e o segundo quando enxerga uma práxis libertadora nos movimento urbanos da periferia de São Paulo.

Quais segmentos e instâncias da Igreja ainda refletem essa visão libertadora? Em que espaço político-social eles se inserem? O que aconteceu, ao longo dos anos, com a Teologia da Libertação? Ela continua como força renovadora da Igreja Católica? Essas questões são fundamentais se queremos analisar o papel histórico do catolicismo e de seus agentes. Maduro, nos ajudar na compreensão da Igreja enquanto instituição, portanto portadora de conflitos internos, que acabam por ser externalizados na ação de seus membros na sociedade.

Apesar dos espaços da política institucional estarem fechados, nos anos de 1970-1980, a experiência das CEBs configurou-se como espaço político, espaço de debate, de discussão, de diálogo, de opinião. Nele se intercruzavam várias opiniões que conformavam a política, estabeleciam visões e concepções que geravam novos consensos ampliando o senso comum (ARENDT, 2008), colocando-o em novos patamares.

Escolhi a Diocese de Crateús para realização da minha pesquisa porque aí as CEBs tiveram vida mais ativa no Ceará (LESBAUPIN, 1997). Além disso, o trabalho de CEB continua nessa Diocese. Até que ponto o estágio em que 
a Diocese se encontra hoje reflete a expressividade política atribuída às CEBs, nacionalmente? Esta é uma pergunta central porque D. Fragoso, primeiro bispo de Crateús e ligado à Teologia da Libertação, responsável por uma visão da Igreja libertadora, ao aposentar-se foi substituído, por um religioso, segundo depoimentos atuais de religiosos ligados ainda hoje às CEBs, vinculado à linha conservadora emanada de Roma?

Outras perguntas se colocam: as CEBs, ainda existentes, atuam no contexto da sociedade local? Discutem sua inserção no mundo do trabalho como explorados e excluídos? Elaboram pautas políticas, cobram do poder público um maior compromisso com seus pleitos e carências? O papel que os padres e bispo exercem no interior das CEBs é de abertura para a discussão sobre a condição da Igreja enquanto instrumento de libertação? Como se articulam nacionalmente? Sua atuação tem em vista a luta por uma sociedade democrática e socialista?

Estas são questões que pautaram também a análise das CEBs nacionalmente. Ainda se promovem encontros nacionais e a grande questão é sobre o nível de participação dos leigos, das questões que são levantadas, dos temas centrais e sua contribuição para uma inserção do leigo na vida da sociedade.

Considerando os elementos até aqui problematizados, proponho como objetivo geral analisar a inserção da Igreja Católica na sociedade, a partir dos anos de 1970, na Diocese de Crateús, tendo como elemento de reflexão a ação das CEBs e dos religiosos ligados à Teologia da Libertação e sua ação educativa na formação da classe trabalhadora.

Entendemos por Comunidade Eclesial de Base todo um movimento nascido na Igreja Católica com o objetivo de discutir a fé e a justiça a partir dos injustiçados, daqueles que reclamam por justiça a partir da opressão a que estão submetidos. Opressão que se revela econômica, política e socialmente, marginalizando grande parte da população mundial. 
Identificando a CEB como pastoral popular, afinal ela o é, pois atua prioritariamente entre os segmentos populares, Perani diz:

\begin{abstract}
Entendemos por pastoral popular todas as iniciativas da Igreja no âmbito das classes populares, nas quais o povo encontra um espaço para assumir sua responsabilidade na vivência de uma fé comprometida com os problemas da justiça... $\mathrm{Na}$ medida em que as comunidades de base iam surgindo, logo se apresentavam - além das intenções - como um espaço, não somente de reivindicação social, mas também político, quer dizer como um espaço de contestação do poder da Igreja, seja do Estado, seja do Capital. (PERANI. CEAS, № 82, p. 7)
\end{abstract}

A ação das CEBs se assenta sobre uma nova postura de Igreja, nascida no Concílio Vaticano II, na sua relação com as populações mais pobres da África e da América Latina. É toda uma reflexão que se faz a partir da situação de pobreza dos povos do chamado terceiro mundo decorrente de relações colonialistas que os submeteram aos interesses dos países centrais da Europa e da América do Norte. Nesse sentido conforma e é conformada por uma nova visão de Igreja, igreja voltada para os pobres, para sua realidade de oprimidos e necessitados, carentes de justiça.

Essa visão centrada na realidade sócio-cultural do povo pobre, que tem como exemplo Jesus, que sofreu o martírio, que se identificou com os pobres do mundo e, por isso, nasceu pobre embasa o que, a partir de então, passou a ser chamada de Teologia da Libertação, implica dois momentos fundamentais: um voltado para a sociedade e suas contradições e o outro para a Igreja criticando a sua existência histórica e comprometendo-a com a história e com os pobres do mundo. Na fala de Pablo Richard fica clara essa relação dialética Igreja-povo de Deus ou as comunidades eclesiais de base enquanto espaço de existência de uma nova igreja:

As comunidades eclesiais de base são os pólos onde se acumula consciência, conhecimento e capacidade de julgar; memória, história e criatividade teórica. É ali também onde se manifesta o melhor da santidade na luta pela justiça; onde abundam os testemunhos e se geram os mártires. (...) Esta teologia tão simples, constituída sobre estes três elementos 
que temos mencionado (Reino, História e Igreja), corresponde à vivência espiritual das Comunidades Eclesiais de Base no interior do movimento popular. O movimento popular não é somente um espaço social e político, mas também o lugar do encontro com Deus. (RICHARD, 1984)

No início dos anos cinquenta do século XX aumenta a preocupação da lgreja com o campesinato. Ela se preocupava com a expansão do Partido Comunista Brasileiro, que através dos sindicatos e associações de lavradores se tornava mais presente no meio rural. Deste modo, ela intervém. E sua intervenção, segundo Martins (1995), era preponderantemente conservadora por temer uma revolução social em bases marxistas. Sendo assim, para estabelecer sua atuação na relação com a população rural ela reúne proprietários de terra, professores e outros profissionais, menos os próprios trabalhadores do campo.

A preocupação da Igreja com a questão agrária começa a expressar-se, de modo mais consistente, por uma carta pastoral do bispo de Campanha, uma diocese do interior de Minas Gerais, D. Inocêncio Engelke, de setembro de 1950. Ela resultou de um encontro de 60 párocos, 250 fazendeiros e 270 professores rurais. Neste encontro não esteve presente nenhum trabalhador rural, nenhum camponês... A carta pastoral de D. Inocêncio é de teor nitidamente conservador. Sintomaticamente, o documento surgiu poucas semanas após - Partido Comunista do Brasil ter lançado um manifesto a favor de uma reforma agrária radical. (MARTINS, 1994, p. 100)

Nos vários encontros promovidos, antes dos anos de 1960, a Igreja revelava a mesma preocupação: evitar que os comunistas entrassem no campo. A proposta, aventada por ela, era melhorar as condições de vida dos trabalhadores, minorar o processo de exploração no campo, ampliar a escolaridade e, inclusive, reformar a estrutura fundiária, gerando uma classe média proprietária capaz de resistir à influência marxista.

Foi então que se conheceu uma Igreja mais agressiva em termos de defesa dos interesses da classe trabalhadora rural, colocando-se como intermediária de suas reivindicações e até numa postura de frente, no que diz respeito à sua organização e às mudanças das condições de miséria e de exploração desse segmento da sociedade. Com esse propósito, 
promovem reuniões, estudos e discussões sobre as questões que afligiam o campo brasileiro e se lançou na execução de programas de assistência sócio-educativa e até de mobilização e organização política, como no caso do Nordeste, onde desenvolveu um trabalho de mobilização, organização e fundação de sindicatos. (CRUZ, 1985, p. 64)

Mesmo sabendo ser esta a orientação da Igreja, não se pode afirmar que ela, como um todo, em todas as suas instâncias, partilhava da mesma perspectiva. Nem todos temiam os comunistas ou compartilhavam do reformismo social da igreja. Alguns segmentos preocupavam-se com a construção de um modelo de sociedade baseado na igualdade. É claro que não era um segmento predominante, nem poderia sê-lo. Concordo com Maduro quando afirma que a Igreja é uma instituição social perpassada pelas contradições inerentes à sociedade, predominando, no seu interior, aqueles que eram, ideologicamente, associados aos segmentos dominantes.

Em outras palavras, uma estrutura objetivamente conflitiva de dominação social - que é a que preside as sociedades de classe - condicionará, de maneira peculiar, quais ações religiosas são, nela, impossíveis, quais são possíveis mais indesejáveis, quais são toleradas e toleradas até certo ponto, quais são admissíveis, mas em plano subordinado, quais são convenientes e quais ações religiosas são primordiais e/ou urgentes (independentemente da consciência e da vontade dos agentes religiosos). Quer dizer, a estrutura conflitiva de dominação de qualquer sociedade de classes estabelece de uma maneira específica - ligada à diferenciação de classe em seu seio e às relações assimétricas de poder entre elas- os limites dentro dos quais uma religião pode operar em seu seio e as tendências que atravessarão e orientarão a atividade de tal religião nessa sociedade. (MADURO,1983, p. 82)

Após 1964, o próprio processo ditatorial instalado no País acaba por provocar entre a igreja e os segmentos dominantes uma ruptura que permite a emergência dos mais radicais dentro desta instituição. $O$ modelo reformista, reformar para não entregar, proposto pelos conservadores, no interior da Igreja, cai, na medida em que as elites agrárias percebem a possibilidade de acabar com os conflitos, no campo, através dos aparelhos repressivos do Estado. A própria igreja passou a ser vista como instrumento desta instabilidade (MARTINS, 1994, p. 104). 
A partir dos anos de 1970, o aprofundamento das divergências entre setores da Igreja Católica e os militares chegou ao seu ponto mais alto. Em primeiro lugar, pela opção dos agentes pastorais, por um modelo de sociedade mais igualitária. Depois, como uma consequência natural, a Igreja é transformada no canal natural das reivindicações da sociedade civil, na ausência de um aparato partidário que comportasse a insatisfação popular.

\begin{abstract}
Após 64, essa análise crítica assumiu uma importância maior. Quando os generais se apoderam do governo, todos os demais grupos que trabalhavam por mudanças sociais foram sufocados. As CEBs, que pareciam inócuos grupos para estudo da Bíblia, puderam continuar existindo, tornando-se assim o único espaço para expressar dissensão durante os anos mais repressivos do regime militar (ADRIANCE. $1996 \mathrm{p}$. 178).
\end{abstract}

A Igreja passou a organizar os segmentos populares, multiplicando as comunidades de base. Inicialmente, associações de católicos voltadas para os serviços religiosos, para depois agregar os incomodados pela ação do estado autoritário. (ADRIANCE, 1996)

Essas comunidades de base se espalhavam no campo e nas cidades, principalmente entre os chamados excluídos: excluídos da terra, do trabalho, dos serviços públicos fundamentais, da moradia, dos direitos. No processo de organização desses segmentos, a Igreja se transformou no grande agente de articulação entre eles, gerando o que Martins chama de novos sujeitos da história. (MARTINS, 1984)

É interessante frisar que a Igreja não participou apenas como elemento aglutinador, mas, também, é ela, através de seus agentes, sujeito do processo de transformação conforme Maduro (1983, p.158). É uma guinada substantiva que imprime uma direção inteiramente nova ao catolicismo somente possível após o Concílio Vaticano II. Aliás, não se pode ignorar que este Concílio é uma exigência de modernização que há muito se fazia necessária ao catolicismo. 
Para fazer frente ao crescimento das esquerdas marxistas na América Latina e em todo o mundo, a Igreja Católica não pôde ignorar as transformações dos dois últimos séculos. Apesar do crescimento da indústria, que provocou o crescimento das cidades, o aumento dos empregos e a modernização do campo, que aumentou a produção de alimentos e baixou seus preços, a distribuição da riqueza se deu de forma desigual. $O$ resultado das transformações, provocadas pela emergência do capitalismo, foi a acumulação do capital.

Este processo de acumulação revolucionou as relações de produção originando nova divisão internacional do trabalho, beneficiando os países da Europa Ocidental e os Estados Unidos em detrimento do resto do mundo. Como resultado, emergiram organizações sindicais e partidárias opostas ao capitalismo, que estabeleceram como objetivo a superação do mesmo como forma de produção da riqueza. Eram organismos sociais laicos e em oposição à igreja católica que, ignorando sua mensagem fundadora (FOLLMANN, 1985), associava-se aos segmentos dominantes.

$\mathrm{Na}$ América Latina, os princípios vitoriosos no Concílio Vaticano II, permitiram a organização do clero e dos leigos numa pastoral comprometida e articulada, que, em Medelin, estabeleceram o marco de sua ação continental (COMBLIN, 1996). Neste contexto, poderia ser explicada a atuação da Igreja Católica no Brasil, como instrumento de resistência e de discussão de alternativas de poder, que resultaram na ampliação da participação das populações excluídas e na redemocratização do País.

Da ação dos agentes e das bases das comunidades eclesiais, surgiram, no processo de redemocratização, dois instrumentos de organização e luta contra o capitalismo e sua estrutura de poder: o Partido dos Trabalhadores (RODRIGUES, 1990, p. 12) e o Movimento dos Sem-terra (FERNANDES, 1996, p. 68). 
Para Martins, os agentes pastorais, ligados às CEBs, acreditando que estas tinham limitações estruturais, que a transformação das relações de produção somente poderia ocorrer através dos partidos e dos sindicatos, optaram por estes. Com isso, segundo o autor, a ação da igreja diminuiu sua eficácia e sua inserção mais direta na sociedade, deixando para estas instituições sociais e políticas o papel de sujeitos da história.

As tendências e os grupos de esquerda acabaram tendo êxito em convencer agentes de pastoral de que de nada adiantava todo o trabalho que faziam se sua proposta não fosse além dos limites da esquerda e da religião... Em consequência, também, os sobrepostos objetivos políticos impuseram a forma de mediação que viabilizaria o processo: a organizaçãoo sindicato e o partido político. Finalmente, a própria mediação passou a definir a identidade do sujeito (o trabalhador genérico), que devia enquadrar-se no estereótipo, assumir sua ideologia e projeto. E a natureza do projeto e das necessidades históricas de que decorria. (MARTINS. 1994 p. 161)

É claro que as mudanças no comportamento da igreja católica não se explicam apenas pelas mudanças internas, ocorridas com a redemocratização e o fortalecimento dos instrumentos institucionais de luta, até porque estas mudanças não provocaram, de imediato, mudanças nas políticas de exclusão. Pelo contrário, em algumas instâncias, aumentaram. Como explicar então o retraimento da igreja e dos seus agentes, que deixaram de atuar como sujeitos ativos no processo de construção de uma oposição às elites dominantes?

Para alguns autores, dentre eles Beozzo (1996) e Comblin (1996), a ausência da igreja hoje, no contexto político nacional, deve-se a mudanças que ocorreram em Roma com a eleição de João Paulo II. A política do Vaticano, instituída a partir daí, preocupava-se com o crescimento do movimento leigo e na importância que este assumia na determinação das ações pastorais, escapando ao controle da hierarquia.

Tais movimentos sociais encetados pelos agentes pastorais acabavam por provocar conflitos, aumentar as áreas de atrito entre a instituição e os 
estados nacionais latino-americanos e ameaçar a sobrevivência da Igreja como instituição multinacional. Para continuar como tal, precisava manter a unidade e, ao mesmo tempo, respaldar-se nos, e através, dos governos nacionais. Caso contrário, desapareceria como igreja mundial, transformando-se em várias igrejas nacionais e locais, de acordo com as conjunturas e as correlações de forças postas a serviço da sociedade civil.

Essa perspectiva preocupava, por um lado, os progressistas, que viam esta unidade como necessária para a penetração da Igreja, principalmente na América Latina, em todos os segmentos sociais. Por outro lado, preocupava os conservadores que viam a influência da Igreja respaldando um modelo de sociedade assentada na reprodução ampliada do capital. Como aparelho ideológico do Estado, ela seria responsável pela reprodução do poder instituído e, ao mesmo tempo, se beneficiária dele. Miguel Pressburger e Maria Tereza de Araújo, reproduzindo fala de D. Tomás Balduino dizem:

O Vaticano e a casa Branca podem formar suas alianças, unidos nas suas preocupações e interesses. A frase é do bispo de Goiás, D. Tomás Balduino, comentando as últimas decisões da Santa Sé em relação a Igreja do Brasil. ...O continente latino-americano é uma constante preocupação da Casa Branca, Pentágono e de Wall Street, onde os credores temem explosões sociais em larga escala. Os estrategistas do Pentágono têm estudado o fenômeno da presença da Igreja nos movimentos sociais e criaram o Instituto de Religião e Democracia. "Consta que foi a partir de 1979, quando João Paulo II sobrevoou a América Central e saudou o então presidente Ronald Reagan, que foi dinamizada a ação deste Instituto para a América Latina. (PRESBUGER e ARAUJO,1989, p.45)

Martins, discutindo as questões acima, diz não haver, na realidade, um retorno do conservadorismo, sua tese é que os bispos sempre foram conservadores mesmo quando, em determinados momentos, portam-se como progressistas:

Neste sentido, eu diria, concluindo, que os bispos, de fato, não se converteram e não havia porque fazê-lo. Sua interpretação da realidade e sua ação pastoral é que se tornaram profundamente transformadoras porque, na 
sociedade brasileira, o desenvolvimento capitalista dissemina a pobreza e não a riqueza e o bem - estar; e também porque, nessa sociedade, as instituições da justiça fundamentalmente disseminam a injustiça. (MARTINS, 94, p.144)

Sua análise, no entanto, entra em choque com aquela feita por Gómez de Souza. Este afirma que a Igreja, como instituição social, é progressista, quando evoluem as forças sociais neste sentido e conservadoras quando são conservadoras as sociedades ou aos segmentos dominantes nestas sociedades. Diz o autor:

A Igreja, como expressão organizada de uma atividade religiosa, está inserida na sociedade e seus membros pertencem simultaneamente à estrutura de classes desta sociedade. Eles levam, pois, para o interior da Igreja os conflitos e as alianças da própria sociedade.

Claro está, de maneira semelhante, que assim como a ideologia dominante na sociedade é a ideologia da classe dominante, a expressão religiosa principal está também vinculada a esta classe. Mas é relativamente fácil perceber como sobrevivem e nascem outras expressões ideológicas, tanto nas antigas classes dominantes em decadência, como nas novas classes que emergem na sociedade. O mesmo acontece com as práticas religiosas. "Podem-se descobrir diferentes expressões religiosas que são contraditórias entre si e que correspondem a lugares sociais diferentes. (SOUSA. 1984, p. 25)

Mas a fala de Martins talvez esteja apoiada na compreensão de que esses bispos, de nacionalidade européia, sejam oriundos de sociais-democracias. Nesse caso, faltaria a eles a visão crítica que vê o capitalismo como uma totalidade que se faz e se dissemina de forma desigual em seu processo de expansão. Acredito que no contato com as realidades do terceiro mundo, acabaram por perceber a natureza excludente do capital como sendo uma característica própria do capitalismo latino-americano.

Para Perani, o engajamento político da Igreja teve como resultado a diminuição da participação de inúmeros católicos nos movimentos promovidos por ela. 
A pastoral deveria apresentar-se como espaço aberto onde as propostas e a atuação concreta das várias organizações e correntes possam ser analisadas, deixando a seus membros maior responsabilidade de escolha, sem impor algo a partir da instituição pastoral. Deveria ter uma atitude de discrição política, não porque deva ocupar-se só do aspecto religioso da luta do povo, mas porque seu serviço/anúncio, ao tempo que se concretiza em experiências sempre mais políticas, deveria perder aquele dogmatismo que provém da fé, para diluir-se numa pluralidade de forma que dificilmente podem coincidir com o próprio anúncio. (PERANI. 1989, p.16)

Segmentos dentro da Igreja levantam que a politização dos movimentos ligados a ela acabou por descaracterizá-la, deixando de lado o aspecto salvacionista. Deste modo, atacam o trabalho de CEB e retomam uma concepção de igreja alheia aos problemas sociais. Mas, a visão de Perani, apesar de preocupado com o possível esvaziamento da Igreja, não indica que esta esteja ausente da questão política; pelo contrário, apenas indica uma possibilidade de ação política que não resulte exclusiva, como única opção da ação pastoral. São nuanças que acabam, ao longo da discussão da hierarquia, a justificar uma guinada conservadora.

Com o pontificado de João Paulo II, houve uma preocupação em frear o radicalismo das comunidades eclesiais de base e voltar-se para a questão efetivamente religiosa. Seus pressupostos estão vinculados a uma concepção de igreja e de salvação que a diferencia da igreja como espaço privilegiado de libertação pregado pelas CEBs e pastorais. Afinal, estas entendem que o papel da Igreja Católica no Brasil é fundamental para a inclusão do povo marginalizado na vida política.

Mas, se de um lado alguns teóricos, inclusive aqueles que são ligados à Igreja Católica, como Comblin (1996, p.78), Beozzo (1996, p. 210) e Dussel (1999, p. 103) atribuem a crise ou o retraimento das CEBs à ação conservadora assumida por Roma, outros enxergam nesse retraimento, uma consequência do retorno da democracia e de suas instâncias de participação, como os partidos e os sindicatos. 
Martins (2003), numa visão mais ampla, propõe como fundamento do recuo dos movimentos sociais, dentre eles as CEBs, como uma consequência, também, da posição das lideranças ou agentes de pastoral. Comprometidos com partidos de esquerda e com uma visão estreita do marxismo, fechavam as possibilidades de compreensão da realidade multifacetada do campesinato, de suas contradições internas, de subsunção ao capital, e dos horizontes que desenhavam para superar suas dificuldades. Diz ele:

\begin{abstract}
Populações que no passado se expressavam politicamente através das relações de dependência pessoal e de clientelismo político passaram a se expressar também através desses novos grupos, sob uma nova modalidade de sujeição ideológica e de clientela. De certo modo, essa novidade assinala a fragilidade dos partidos políticos e do sistema partidário, como meios de expressão da vontade política da sociedade, ainda dependentes de mediadores extrapartidários para o exercício da função partidária. $O$ fato revela, também, um problema que não pode ser ignorado no trato da questão das demandas sociais. A ação desses grupos de mediação responde em boa parte pelo esvaziamento e instrumentalização partidária dos movimentos sociais e pelo declínio do espaço que lhes é próprio na sociedade contemporânea. Esvaziamento, também, da vitalidade que Ihes assegura inovação e criatividade tanto nas demandas quanto nas soluções dos problemas que os motivam. A provável novidade política do cenário contemporâneo no Brasil está no surgimento de agências de mediação política das demandas sociais que, entre o cidadão e o partido, interpõe uma rede de canalização e, sobretudo, de tradução de demandas populares em demandas político-partidárias. (MARTINS, 2003, p. 28)
\end{abstract}

Para mim, o importante é que o fenômeno CEB existiu e existe, existiu e existe de forma plena em determinado momento da nossa história recente e que teve papel fundamental no processo de redemocratização, que, no meu entendimento, não se colocava como fim, não como de fato aconteceu. Não podemos de antemão decidir sobre os acontecimentos futuros, eles são uma consequência do momento presente, mas um momento em que forças diversas atuam resultando em uma realidade diferente daquela desejada pelos atores sociais. 
Se, como afirma Martins (2000), os agentes das pastorais, como também os das CEBs, eram oriundos da classe média, militantes das mais diversas agremiações de esquerda; se em função disso tinham visões superficiais, distorcidas, distantes da realidade do campesinato brasileiro, mesmo assim sua inserção não pode ser ignorada, é um dado com o qual os analistas têm que lidar. A história, sempre é passado, não pode ser mudada; o que se pode fazer é verificar as consequências e as distorções que provocaram no processo de formação do campesinato como sujeito da história. A realidade social é complexa, como é complexa a questão do campo que, para Martins, os agentes desconheciam, ou não enxergavam, em função de suas posições (ou devaneios) políticas. O processo histórico ocorreu, o resultado foi aquele que estamos vivendo hoje e é com ele que devemos lidar. Avaliar os erros, mas sabendo que isso não é garantia de acerto no presente, cabe apenas avaliar como essas forças interagiram e como os segmentos sobre os quais agiam, reagiam ou reagem hoje. Acredito que - e essa crença deve operar aqui como hipótese de investigação - apesar de tudo a ação dos agentes de pastoral resultou em visões mais amplas, capazes de indicar um percurso histórico mais denso com resultados políticos que merecem maior reflexão.

Caberia apelar para Arendt (2008): foi criado um espaço público da fala, muitas "opiniões" expressadas contrapondo-se umas às outras, originando uma verdade que se afirma e eleva o senso comum. Feltran (2005) aproveita-se desse marco teórico arendtiano para observar com maior profundidade a atuação das associações de bairro da cidade de S. Paulo. Para ele, elas tiveram um papel fundamental na formação de uma consciência crítica e exigente, entre seus associados, que passaram a perceberem-se como sujeitos de direitos. Sem esses espaços públicos da fala, gerados por associações muitas vezes lideradas por indivíduos comprometidos com segmentos político-partidários e religiosos de matizes ideológicos diferentes, não haveria a emergência política dos sem-direitos.

Compreendendo que os sujeitos históricos são o resultado de muitas determinações, volto-me para a compreensão da classe a partir das CEBs, 
que são totalidades, não diretamente ligadas à produção, mas com ela mantendo um vínculo por manter uma identidade caracterizada pela carência, carência de terra, de emprego, de justiça, de cidadania.

Martins, em seu texto exemplar, Os Novos Sujeitos dos Direitos e da História (1984) analisa as categorias sociais do campo, apresentando suas diferenças, mas, a partir da teoria do desenvolvimento desigual, revela que, apesar das diferenças, são todas elas subsumidas pelo capital em seu processo de reprodução ampliada. Nesse ponto, afirma a inovação dos agentes de pastoral que elegem, na construção do sujeito coletivo, comunidades eclesiais, a categoria analítica pobreza.

As CEBs, enquanto instituição constituída por esses sujeitos e, ao mesmo tempo, construtora desses sujeitos sociais, na oposição a ordem capitalista ${ }^{4}$, tem um papel educativo que não se pode ignorar. Uma educação que não se dá na escola, mas que repercute na sociedade através da formação de sujeitos de uma nova práxis. Acredito ser pertinente a citação do Manifesto que segue:

Mas dizeis que abolimos as mais sublimes relações ao substituirmos a educação doméstica pela educação social.(...) A vossa educação, não é ela também determinada pela sociedade? Não é determinada pelas relações sociais nas quais educai vossos filhos, pela ingerência mais ou menos direta ou indireta da sociedade através das escolas, etc? Os comunistas não inventaram a influência da sociedade sobre a educação; procuram apenas transformar o seu caráter, arrancando a educação da influência da classe dominante. (MARX. 2002. 63)

\footnotetext{
${ }^{4}$ A referência que faço a "ordem capitalista" não se restringe apenas ao aspecto econômico. Com Marx, quero dizer que o capitalismo é mais que um modo de produção, é uma formação social com base no trabalho assalariado, mas que trás em seu interior resquícios de modos de produção anteriores, recria formas de produção e, nelas relações de produção, não propriamente capitalistas, com suas formas de representação, com estruturas e instituições que lhes são próprias que compõem ou entram em contradição com a forma capitalista de dominação. Para maiores esclarecimentos ver Marx quando se refere, no O Capital, a Saint-Simon, Gorender na introdução ao seu livro O Escravismo Colonial, Martins, quando no texto, Os novos sujeitos das lutas sociais... in Militarização da Questão Agrária. 1984, Löwy em seu livro As Aventuras de Karl Marx contra o Barão de Münchhausem , 2003, dentre outros.
} 
É nesse processo que acredito ser fundamental o papel das CEBs, um papel educativo, educação que se dá na luta a partir da construção dos seus membros em sujeitos sociais. Educação que, num primeiro momento, indica a identidade social dos sujeitos e, depois, articula esses segmentos com a classe fundamental dos trabalhadores assalariados. Na solidariedade que se constrói entre os segmentos explorados, unindo-os numa mesma perspectiva: a de construir uma nova sociedade.

Comentando a terceira tese sobre Feuerbach, Vázquez (1968) afirma a necessidade de uma práxis que envolva os diversos segmentos da sociedade, que em sua ação revolucionária educam as massas. Educação que exige um educador que assuma o papel de educando e um educando que assuma o papel de educador. Mudar as circunstâncias implica em mudar os homens e os homens mudados exigem circunstâncias diferentes, é um processo dialético em que a transformação do real implica, simultaneamente, a mudança daquele que atua sobre o real.

Na tarefa da transformação social, os homens não podem dividir-se em ativos e passivos; por isso não podem aceitar o dualismo de educadores e educandos. A negação desse dualismo - assim como da concepção de um sujeito transformador que fica ele próprio imune à transformação -, implica na idéia de uma práxis incessante, contínua, na qual se transforma tanto o objeto como o sujeito. Ao transformar a natureza - dirá Marx em outro trabalho - o homem transforma sua própria natureza, num processo de autotransformação que nunca pode ter fim. Por isso, jamais poderá haver educadores que não necessitem, por sua vez, ser educados. (VÀSQUEZ,1968, p.160)

Assim, a análise da ação das CEBs não pode deixar de verificar a relação entre os diversos sujeitos dessa prática político-religiosa. $O$ papel transformador somente poderia ocorrer se no processo educativo, os religiosos e os agentes de pastoral assumissem a postura de aprendizes. É interessante frisar que no processo de construção das CEBs, em Crateús, o método de Paulo Freire é utilizado, e o é por suas características libertadoras, por seu compromisso com o conhecimento da realidade e a necessidade de transformá-la. 
Nesses mesmos espaços, o processo formativo ia acontecendo na dimensão intelectual. Também entre os nãoletrados eram socializadas informações úteis. Informações sobre o mundo. Tão importante era essa dimensão, que, no caso de tantos e tantas que ainda não haviam se alfabetizado, antes mesmo de se aplicarem no aprender a ler letras, cuidavam de aprender a fazer a leitura do mundo, passo fundamental na pedagogia de Paulo Freire. (CALADO, 2005.p. 67)

É nesse contexto, da construção conjunta dos sujeitos, onde educadores se transformam em educandos, aprendizes na relação com os educandos, que Martins (2003) critica os agentes de pastoral e mesmo os bispos que atuaram junto às bases no campo como na periferia das cidades. Aliás, postura assumida por ele quando das análises que passou a fazer com relação ao percurso do MST. Até que ponto assumia sua função de mestreaprendiz, dialogando com o aprendiz-mestre, aquele que vivendo a realidade da opressão expressava essa realidade e os seus limites, impostos pela mesma.

Kosik (1985), interpretando Marx, irá acentuar o papel de construtores da realidade assumida pelos homens, mesmo quando a sua práxis é alienada. Sua situação de produtores da realidade é assumida apesar da separação dos produtores diretos do produto de sua ação e daqueles que se apropriam de seu produto sem uma contribuição direta na produção. Realidade que se constrói como realidade fora do homem, sem vínculo com ele, mas realidade é fruto de sua ação. Por isso a distinção entre a práxis alienada e a práxis revolucionária, que Kosik chama de trabalho e práxis.

No conceito de práxis a realidade humano-social se desvenda como o oposto do ser dado, isto é, como formadora e ao mesmo tempo forma específica do ser humano. A práxis é a esfera do ser humano. Neste sentido a concepção de práxis constitui o ponto culminante da filosofia moderna, a qual, em polêmica com a tradição platônico-aristotélica, colocou em evidência 0 autêntico caráter da criação humana como realidade ontológica. A existência não é apenas enriquecida pela obra humana; na obra e criação do homem - como em um processo ontocriativo - é que se manifesta a realidade, e de certo modo se realiza o acesso à realidade. Na práxis do 
homem advém algo essencial, que contém em si mesmo a própria verdade; não é mero símbolo de qualquer outra coisa, mas possui 'uma importância ontológica. (KOSIK. 1985, p. 202)

Compreender as CEBs é compreender até que ponto a sua ação, tanto no que diz respeito à Igreja Católica quanto ao Estado é revolucionária. 0 estado enquanto instrumento das classes dominantes ou no máximo uma instância mediadora em que os direitos são assegurados, via pressão, via sociedade civil, mas como estado liberal, só se reconhece os direitos individuais.

Há uma discussão em Nogueira (2001), como em Boaventura de Sousa Santos (2005) e outros, que sugerem que a sociedade civil ${ }^{5}$ conquistou os chamados direitos de terceira ou quarta geração, regulamentados por força dos movimentos sociais; mas não se trata de fato de "direito" na medida em que sua viabilização não foi ainda assegurada. Nesse caso, não se pode falar em direitos, já que não existem mecanismos para penalização dos "culpados", daqueles que os violam. Por isso, posso afirmar com base nesses autores o que anteriormente foi exposto: o estado em sua forma liberal só reconhece os direitos individuais.

Mas, a abertura para a discussão da realidade, das relações de produção que marginalizam, exploram, excluem, propiciada pelas CEBs, gerou sujeitos sociais que atuaram, como tais, em movimentos políticos e sociais. Sujeitos coletivos que colocaram em pauta reivindicações e 0 reconhecimento dos segmentos populares como sujeitos de direitos e de cidadania; que levantaram a necessidade da superação da ordem atual e desmantelaram alguns elementos básicos da ideologia liberal, principalmente o caráter de igualdade prevalente no direito.

\footnotetext{
${ }^{5}$ Quando me refiro a sociedade civil relaciono-a a formas de organização que não se constituem como classe, na medida em que a classe não aparece como categoria jurídica, ou de direito, mas categoria econômica e política.
} 
Kosik tem outra análise que revela a necessidade da luta coletiva para por fim as sociedades de classe. Para ele, e esse foi um papel por excelência das CEBs, a libertação somente é possível através da luta coletiva. Vejamos:

O homem liberta a si mesmo no trabalho servil só enquanto: 1) esse trabalho se desenvolve como trabalho de mais escravos e não de um único escravo, pelo que se torna potencialmente viável a solidariedade dos escravos; 2) a contraposição real do trabalho dos escravos é o não-trabalho dos senhores, e o trabalho dos escravos é realmente inserido na relação social senhor - servo; só nessa relação prática existe a possibilidade de confrontar, e, portanto de conhecer, as profundas diferenças de condições e de vida; 3 ) o trabalho do escravo é sentido e compreendido como trabalho servil, e como tal existe na consciência do escravo. Esta consciência constitui um incalculável potencial revolucionário... Sem o momento existencial, quer dizer, sem a luta pelo reconhecimento, que acomete todo o ser do homem, a práxis se degrada ao nível da técnica e da manipulação. (KOSIK, 1985, p.205)

Na minha análise, procurei identificar os diversos sujeitos, entendido assim em função das diversas categorias constitutivas das CEBs, sua ação, como sujeitos na sociedade local, na articulação com as demais entidades e instituições com inserção na sociedade global, na sua ação na reconfiguração da Igreja Católica, nas representações motivadoras de uma ação consequente por ampliar direitos e na percepção de sujeitos de direitos.

Sendo assim, procurei identificar, a partir da Diocese de Crateús, nas zonas rural e urbana, como se deu essa compreensão, a compreensão de que os não-proprietários tinham um destino comum. A superação do modo de produção capitalista é o fim, o objetivo do processo de organização e luta de todos os trabalhadores. A construção do socialismo o sonho que se quer construir. Mas naquele momento, há de se lutar pela redemocratização do país e, nessa luta se revelam as comunidades em seu papel conscientizador e político. 
Visitei e entrevistei professores e alunos da Escola de Ensino Fundamental e Médio D. Fragoso, no município de Independência. Nessa escola pude perceber a presença de princípios emancipadores emanados da Igreja de Libertação. São presenças ainda vivas de CEBs, questionadoras e críticas quanto à posse da terra, do seu uso e da sua relação com o mercado.

Para a realização da pesquisa sobre as Comunidades Eclesiais de Base em Crateús e sua inserção política e religiosa procurei identificar contatos que permitissem num primeiro momento perceber a importância das Comunidades na construção da Diocese de Crateús. Depois, que me permitissem a percepção do papel político que ela exerceu durante a ditadura militar na organização da população trabalhadora, nas lutas por direitos e mesmo a percepção dos direitos, direitos que os trabalhadores tinham, mas que não eram efetivados, faltava os instrumentos políticos que tensionasse as relações entre os trabalhadores organizados em CEBs e o Estado, faltava o partido, os sindicatos dos trabalhadores rurais, as associações de bairro e de produtores.

Dentre os contatos, contava inicialmente com o Padre Osmar Alves Flor, atuando no município de Ipueiras, na Diocese de Crateús. Osmar era, nos anos de 1970 e 1980, assessor da Federação dos Trabalhadores Rurais do Estado do Ceará, delegacia do município do Crato. Eu o conhecia desde então, o que facilitava meu trabalho de pesquisa. Através dele tive um primeiro contato com os padres Maurizio e Eliésio. O último acompanhou D. Fragoso desde os anos de 1960 e o primeiro desde os anos de 1980.

Depois, através do Curso de Licenciatura em Educação no Campo, conheci dois alunos que eram de Crateús e dirigentes do Sindicato dos Trabalhadores Rurais desse município. Através deles conheci um pouco da história das CEBs, seu papel na criação dos sindicatos de trabalhadores rurais nos diversos municípios da Diocese. Por meio desses dois alunos conheci outros dirigentes sindicais como Luís Antônio, Maria de Jesus, 
Enoque, Eunice etc. Todos pessoas que estiveram ligados aos sindicatos e as Comunidades Eclesiais.

Através deles cheguei aos assentados do Palmares I, Francisquinha, Antonio Gomes, José Alves e Flávio, professor no assentamento e assentado, Pastora do Assentamento D. Fragoso a dirigente do sindicato dos professores de Crateús, Tchesca. Eunice e Tchesca me aproximaram dos membros da direção do Instituto D. Fragoso: Ivânia, Rosali e D. Nenen. No ano de 2008, estive com outros professores da Universidade Regional do Cariri e com militantes de Organizações Não-Governamentais do Crato visitando a Escola Família Agrícola de Independência, município pertencente a Diocese de Crateús. Conhecemos a escola através do movimento de educação do semiárido. A nossa visita a essa escola foi motivada pela discussão sobre as escolas do campo, sobre a Pedagogia da Alternância e pela implantação da Licenciatura em Educação no Campo na Universidade Regional do Cariri com recursos do Governo Federal.

Nessa escola tivemos contato com professores e alunos. O curso nos foi apresentado com seus princípios norteadores, sua estrutura curricular e a metodologia utilizada: a Pedagogia da Alternância, com seu tempo escola e tempo comunidade. A escola tem como objetivo a fixação do homem no campo, o desenvolvimento de uma agricultura adequada ao semiárido, o uso de tecnologias que permitam o desenvolvimento agrícola. A escola objetiva desenvolver a agricultura familiar $^{6}$, uma agricultura voltada para a manutenção da família agrícola e, secundariamente, produzir alimentos para os mercados locais.

\footnotetext{
${ }^{6} \mathrm{Na}$ minha compreensão o conceito de agricultura familiar, que caracteriza as condições de produção do camponês, termo ainda hoje usado, passa, a partir dos anos noventa do século passado, a modificar seu significado: deixa de representar uma forma de produção que distingue a forma camponesa de produção, para indicar uma agricultura com base familiar mas articulada com o mercado, tendo mesmo a finalidade de produzir para atender ao mercado. A mudança de significado decorre do esvaziamento político revolucionário do conceito de camponês. Ao mesmo tempo a aceitação do conceito de agricultura familiar se deu ou ainda se dá via financiamentos dos bancos oficiais, de programas de governo para cultivos de novas culturas agregadas ao mercado como matérias primas. Assim, como agricultura familiar se institui, se organiza na normalidade da vida no capitalismo, se integra, sua ação política não mais pretende a reformulação do modo de produção capitalista, sua superação como modo de produção, sua ação política disputa sua inserção e os recursos financeiros necessários a essa inserção, procura, por fim, a melhor maneira de inserção na sociedade atual.
} 
Posteriormente, mantive contato com o Padre Elênio. Contato que se deu em primeiro lugar na sede da Diocese de Crateús, mais especificamente na biblioteca onde fui buscar documentos escritos sobre as Comunidades de Base. Padre Elênio era vigário ligado a Diocese de Sobral, com a criação da Diocese de Crateús ficou em Crateús, sendo um dos primeiros padres a assumir o trabalho de pastoral iniciado por D. Fragoso, permanecendo em Crateús até hoje.

O primeiro contato mantido em Crateús foi com o Padre Osmar que se encontrava em Encontro Diocesano juntamente com os padres Maurizio e Eliésio. Esse primeiro encontro resultou em conversa com os três padres sobre generalidades da Igreja, da Diocese e das Comunidades Eclesiais de Base. Lembro que conversamos sobre Padre Ibiapina e sobre a fundação dos sindicatos dos trabalhadores rurais do Cariri, todos eles criados pela Fundação Padre Ibiapina pertencente à Diocese do Crato. $O$ trabalho de CEBs foi enfocado como também a fundação dos sindicatos em Crateús.

Esse foi um primeiro passo, a conversa foi interessante, pois envolveu uma conversa com os padres sobre o tema Igreja e Comunidades de Base, Igreja e política, Igreja e história. As lembranças eram expostas, contrapostas, dando coerência ao que era dito, ao mesmo tempo, que me propiciava uma visão de conjunto clara o suficiente para sugerir os caminhos a percorrer na pesquisa.

No mesmo dia, entrevistei o Padre Osmar levantando seu percurso como assessor da Delegacia da FETRAECE em Crato, da Associação Cristã de Base e do Sindicato de Trabalhadores Rurais do Crato. Nesse período, leigo ainda, sustenta com os trabalhadores rurais sindicalizados e ex-assessores da Escola de Líderes Rurais da Fundação Pe. Ibiapina, o rompimento destes com a Diocese e a criação da Associação Cristã de Base que dará continuidade ao trabalho de formação de lideranças sindicais em oposição aos dirigentes sindicais ligados à Diocese do Crato. Depois, sobre o seu 
desejo, concretizado de ser padre militando na Diocese de Crateús, sua ação e a sua inserção na ação de D. Fragoso.

Depois, estive no município de Independência, como já me referi, conhecendo a Escola D. Fragoso, seus professores e alunos. Nessa estadia, em entrevista com um dos coordenadores do curso ouvi que a escola estava antenada com os princípios da Igreja renovada, com a visão de Igreja e de sociedade que norteavam a ação de D. Fragoso. Afinal, a ação desse bispo estava assentada em mudanças substanciais nas relações de produção, de submissão, de autonomia dos trabalhadores, rurais e urbanos, na observância de direitos legais, já instituídos mas não efetivados.

Para confirmar que os princípios norteadores da ação educativa da Escola D. Fragoso, conversei, sem gravar, com uma das fundadoras da Escola, a irmã Siebra, que confirma a vinculação da escola e de sua ação educativa aos ensinamentos e à ação pastoral e política de D. Fragoso e da Teologia da Libertação. A presença da escola, sua área de abrangência, a pedagogia norteadora da ação educativa, a Pedagogia da Alternância, são responsáveis por uma visão crítica e libertadora, legada por D. Fragoso e as CEBs . No comportamento de todos que fazem essa escola está a prática político-educativa de D. Fragoso. Ele se afastou, mas o trabalho de tantos anos permaneceu norteando as ações dos que conviveram com ele repercutindo nos mais jovens.

O padre Machado está ligado à fundação da Escola D. Fragoso e foi por mim entrevistado. Nessa entrevista ele acentua e a permanência entre as pessoas que conviveram com $\mathrm{D}$. Fragoso e nas pessoas que conviveram e convivem com os primeiros o que ele chama de jeito cebiano de ser, ou seja um comportamento religioso, social e político crítico, comprometido com a ação político libertadora. É isso que acontece na Escola, nos assentamentos, na ação sindical etc. 
Padre Maurizio, vigário de Tauá, foi entrevistado falando de sua trajetória na Diocese de Crateús. Ele chegou por volta de 1980 sendo encaminhado para a Paróquia de Parambu. Na entrevista procuramos falar sobre a sua inserção nas Comunidades, a receptividade que teve pela população de sua Paróquia. É interessante a recepção que teve: questionaram os motivos de sua vinda, seu comprometimento com a ação política das CEBs e exigiram dele a efetivação de seu compromisso no trabalho de reconstrução de cercas. Era padre, reconheciam todos, mas sua aceitação dependia de ser um entre muitos, igual sem regalias.

Sua análise, do tempo de sua chegada, é muito rica na percepção da situação sócio-econômica que envolvia os trabalhadores do campo, principalmente os posseiros. Sua percepção das diferenças políticas entre os posseiros e os Sem Terra, os primeiros reivindicam a propriedade da terra em que trabalham e os outros questionam a propriedade da terra, estes aparecem para os primeiros como usurpadores, igualando-os, portanto, aos latifundiários que questionam o direito à propriedade dos posseiros que a garantiam pelo trabalho de muitos anos. A partir dessa análise se pode abrir espaços para análise que não eram percebidos por mim até aquele momento, principalmente a relação dos trabalhadores e dos diocesanos com - MST, criado a partir da Pastoral da Terra envolvendo membros das Comunidades Eclesiais.

São entrevistas que possibilitaram questões, que indicaram caminhos que foram completados por formas de organização que se vão consolidando com o tempo, nas disputas, nos choques internos e externos às Comunidades, nas dificuldades encontradas pela vida em época autoritária e na relação com os proprietários latifundiários que não reconhecem direitos instituídos, mas não efetivados ou consolidados, usando de sua força para negar direitos adquiridos, assim afirmando o que todos já sabiam: nesse país os segmentos populares não constituem cidadania. 
Junto aos dirigentes sindicais e sindicalizados, fomos procurar os percursos, o compromisso da Igreja consolidado com a vinda da sindicalista francesa que irá discutir a necessidade da organização sindical, do conhecimento da legislação trabalhista, das formas de pressão sobre o judiciário e sobre os políticos para que os direitos sejam efetivados.

Nesse caminho, o caminho da organização e da efetivação dos direitos, vão se construindo novas percepções, ampliando outras formas de ver a realidade e as relações de poder e de trabalho. O mais interessante é perceber que nas áreas onde anteriormente era discutida a ocupação de propriedades improdutivas se afirma o MST e se coloca como justa a invasão e ocupação dessas propriedades, garantindo assim a transferência dessas propriedades para os ocupantes sem terra. A entrevista, na realidade na conversa gravada que tive com os assentados do Palmares I, pude perceber as dificuldades encontradas, inicialmente, pelos assentados que eram chamados de ladrões de terra, revelando que na década de 1990 ainda havia preconceito e incompreensão no tratamento político dos sem terra. Somente com o andar da questão, com a exclusão cada vez maior de parceiros e moradores, da dificuldade de encontrar terras para cultivo, é que passa a ser justificada a invasão.

Depois, em conversa coletiva mantida com os padres Osmar e Eliésio, fui despertado para algumas questões que considero fundamentais: a articulação do D. Fragoso com bispos, padres e ordens religiosas, segundo ele responsáveis pela permanência de D. Fragoso em Crateús e a reação do padres conservadores com as CEBs, a presença das CEBs democratizaria a Igreja retirando o poder à hierarquia, igualando leigos e o clero no trato com o sagrado.

São percursos que vão aparecendo e permitindo visões mais amplas da realidade, das relações construídas e mantidas que determinaram a ação das CEBs e seu significado político, social e econômico. As entrevistas foram um caminho para descoberta da CEBs em toda sua complexidade de 
entidades que enfeixavam percepções, cosmovisões a serem transformadas em veiculo de transformação sócio-política da realidade local e regional.

Mas, na minha visão, muito mais consequente foram as conversas que reuniram várias pessoas a discutir temáticas cebianas. As conversas se cruzavam, ampliavam as falas, costuravam sentidos e provocavam reinterpretações dos fatos e acontecimentos que envolveram e envolvem as CEBs. Nessas conversas pude perceber a reação as ocupações, os debates que geraram e as mudanças de percepção que provocaram. Flávio que no início assumia a crítica radical ao MST e as ocupações, achando que eram ilegais, portanto, injustas, pois iam contra o direito universal à propriedade, mudar sua visão, na medida em que rareavam as terras para cultivo familiar e essa realidade ameaçava a vida de muitas famílias de trabalhadores.

Com relação ao movimento sindical, criado pela Diocese com o apoio ativo da sindicalista francesa, em cima de bases radicais que criticavam a natureza das relações de produção no campo, poucos anos depois ser apropriado por dirigentes sindicais que usavam o movimento sindical em benefício próprio, aceitando inclusive a ingerência dos proprietários de terra e dos funcionários do aparelho estatal. Mudança que provoca reação dos sindicalizados e a organização de uma oposição sindical, construída em torno da liberdade sindical, contra o atrelamento ao Estado e a favor da luta pela efetivação do direito à cidadania.

Ao lado das entrevistas pessoais e coletivas, das conversas informais, procurei, junto a particulares e à biblioteca da Diocese documentos que me permitiram ter acesso a uma análise mais crítica, fruto de uma reflexão que levava em conta as nuanças da realidade vivida, experimentada, das contradições que emergiam ao longo do caminho das CEBs e da Diocese enquanto Igreja viva.

D. Fragoso fomentava as avaliações e a memória, escritas, porque serviam para a reflexão crítica dos percursos, para a correção de cada ação, para a 
avaliação e revisão dos caminhos e dos objetivos assumidos por todos. A memória servia também para se avaliar as motivações das pessoas envolvidas, as mudanças nessas motivações e apreciar os espaços abertos nesse caminhar que permitiam o amadurecimento de cada um e de todos através dos diálogos que se construíam.

Nesses cadernos aparecem discordâncias, ciúmes, mágoas que servem para rever posições, indicar correções etc. A leitura deles me permitiu enxergar nas análises o sentimento de todos e de cada um, dos percalços enfrentados, dos conflitos que emergiram como uma consequência da ditadura militar e da presença de um batalhão do exército em Crateús. Claro que os conflitos não são uma consequência apenas do regime militar, há de fato uma divisão na sociedade, de um lado os trabalhadores do campo em seus diversos formatos, como posseiros, parceiros, moradores, assalariados temporários e do outro os proprietários latifundiários, os comerciantes, a burocracia das instituições públicas e privadas associadas as elites e a seu serviço. Os interesses desses segmentos são díspares, são opostos e isso é percebido e colocado desde o início pelos religiosos e leigos ligados as Comunidades de Base como o direito à terra a quem nela trabalha, a questão dos posseiros em Parambu, na fronteira do Ceará com o Piauí, as indenizações para os moradores que estão sendo expulsos das terras em que trabalham na medida em que seus direitos são reconhecidos e os assalariados quando requerem melhores salários e uma regulamentação que evite sua demissão.

Neles se discute questões envolvendo a Igreja, seus compromissos com os mais pobres, a necessidade de inserção popular, de modificar a relação dos religiosos com os leigos, a participação mais efetiva no meio social e dos leigos na Igreja. São várias questões que envolvem dentre elas a formação de um conselho constituído por padres e leigos para gerir os negócios da Igreja, antes havia esse conselho constituído por religiosos sob a presidência do Bispo Diocesano, com a vinda de D. Fragoso o conselho pode ser presidido inclusive por leigos. 
Esses cadernos permitiram enxergar um movimento de base, incipiente, mas ativo em sua relação com os segmentos populares, constituindo-se em alicerce para as ações iniciais de D. Fragoso. Expressa os conflitos entre os segmentos renovados e conservadores, inclusive com os últimos denunciando o Bispo e seus auxiliares mais diretos como comunistas. Verifica-se a presença de grupos de esquerda em organização procurando 0 apoio de D. Fragoso por seu compromisso reconhecido com os pobres etc. A leitura desses cadernos permitiram uma visão mais ampla da inserção da Igreja de Crateús na região diocesana permitindo um olhar mais plural: a Igreja de Crateús não era assumida pelo Bispo de forma autoritária, lá se construía uma Igreja mais inserida e mais plural, com segmentos que discutiam e afirmavam caminhos, unificava lutas, superava as contradições e, com isso, inaugurava a atividade política como uma prática cotidiana.

O cuidado de D. Fragoso em ter dados, análises e avaliações sobre o trabalho que juntamente com leigos e religiosos realizava era uma constante. Para ele, esses dados coletados, sempre com rigor, ajudavam a rever, a repor caminhos, ajudava na reflexão, superava a visão ingênua para uma visão mais científica, garantindo a percepção dos movimentos e as escolhas mais adequadas à realidade. Em nome do rigor ele convidou a equipe do ISER, sob a coordenação de, para realizar pesquisa que indicasse - trabalho das Comunidades a partir da quantidade de CEBs, sua localização, as lutas que enfrentavam, o trabalho político e educativo que realizava, as vitórias e derrotas, a influência dos militantes de CEB nas organizações sociais, sobre o conjunto dos trabalhadores, nos partidos políticos e na denúncia da ditadura e, posteriormente, da redemocratização conservadora.

Através dos dados apresentados na análise do ISER pude verificar os focos das CEBs, as lutas desenvolvidas, as reivindicações, o envolvimentos dos membros de CEBs, a relação dos mesmos com os religiosos e com o Bispo. Pude constatar o trabalho de educação permanente, uma educação crítica que envolvia desde as crianças, passando pelos jovens e adultos, homens e 
mulheres. Nessa pesquisa ficou claro as afirmações de Frei Beto, de Perani, de C. Boff e do próprio D. Fragoso de que as CEBs são espaços políticos, espaços nos quais se organizaram e se organizam os segmentos populares.

A realidade é dinâmica, não é apenas a apreensão teórica da mesma que indica a compreensão do real. Para apreendê-la e mesmo verificar a sua adequação, é necessária a ação. Aliás, o conceito decorre do processo de construção mesmo do real através da ação cada vez mais qualificada. Neste caso, observação e o registro de informações sobre a participação dos membros de CEBs nos sindicatos, nos partidos políticos, na militância, em cargos eletivos foi fundamental. Procurei em algumas manifestações promovidas atualmente, exemplo disso foi a greve dos professores municipais de Crateús, ocorrida durante o ano de 2011, a presença de membros atuais e antigos das CEBs revelando sua importância como instrumento de educação política fundamental.

O trabalho que segue está dividido em quatro capítulos. No primeiro deles, intitulado Debate Preliminar, procuro situar melhor a Igreja Católica nas lutas do povo por libertação, contra a opressão e a favor da ampliação dos direitos ao conjunto da sociedade. Não se quer dizer que não existam direitos, todos os cidadãos brasileiros têm direito, mas sua efetivação se dá de maneira diferenciada, as elites os têm assegurados, os segmentos populares não conseguem assegurá-los nem mesmo nos tribunais. Faço essa análise em Crateús, mas situando Crateús no contexto mais amplo da sociedade brasileira principalmente nos anos da ditadura.

Dessa forma, vou clareando o objeto, o papel da Igreja Católica no processo de formação da classe trabalhadora a partir dos anos de 1960, focando a ação das Comunidades Eclesiais e os religiosos ligados à Teologia da Libertação; as hipóteses, centradas no autoritarismo e no fazer política numa sociedade autoritária; e os objetivos desse trabalho. e das minhas preocupações com o processo de mudança no Brasil e da constituição de 
uma cidadania plena. Preocupação que vem desde a década de 1980, quando fiz meu mestrado na Universidade Federal do Ceará.

Essa preocupação estava marcada pelas diferenças sociais e econômicas que marcavam a sociedade brasileira, não conseguia enxergar as possibilidades de constituir sujeitos a partir do processo político, afinal a história brasileira estava marcada por períodos autoritários que apareciam quando a população, principalmente os segmentos populares, procurava espaços políticos para sua ação. Mesmo quando da normalidade partidária, quando os partidos existiam livremente, eles mesmos não eram capazes de se fazer canais de expressão das camadas populares. A sociedade como um todo era autoritária e hierarquizada não permitindo senão a confirmação dos privilégios, nenhum partido se propunha a ampliar os espaços de expressão popular, apenas a Igreja Católica faz isso, e o faz em um momento em que achava pressionada pela esquerda marxista e por outras expressões cristãs, pelo menos assim me parecia quando iniciei minha análise sobre a emergência dos segmentos populares nos anos de 1980.

Nesse capítulo, portanto, tento ligar minha primeira análise, de uma Igreja que instrumentaliza com sua doutrina os segmentos populares na sua luta pela cidadania, mesmo nos contextos mais conservadores, a uma lgreja que se insere, estimula, motiva, a ação popular dentro de um contexto aberto na qual a própria Igreja se transforma.

No segundo capítulo, Desenvolvimento de Comunidades e Renovação da Igreja, procuro reconstruir os elementos que foram aos poucos conformando sujeitos à convivência comunitária, tanto elementos de uma prática comunitária, surgidos a partir da ação do Estado e de instituições ligadas ao mesmo, como elementos de uma prática religiosa que tenta recuperar o modo de ser das comunidades cristãs primitivas. Essas duas tendências objetivavam em sua ação ativar solidariedades que permitissem a resolução dos problemas vividos, principalmente pelas comunidades rurais. Discuto o caráter reformista das duas formas comunitárias, uma com 0 desenvolvimento de comunidades e a outra, com caráter religioso, mas, 
também, tendo em vista a promoção do homem em sua integralidade. Esta de cunho mais religioso do que leigo, procura o fortalecimento da família como um instrumento fundamental da ética nas relações humanas. São tendências que se encontram e se separam na medida em que a discussão religiosa no contexto da comunidade, com base na leitura bíblica, foca o pobre e a superação da pobreza, a exploração a que está submetido o pobre e as formas de superação da exploração.

Nesse capítulo, verifico também a ação da Igreja Católica em Crateús, procurando nessa ação a construção de uma nova prática católica que permita posteriormente a ação pastoral de D. Fragoso na criação e desenvolvimento das Comunidades Eclesiais de Base. Essa investigação tem como pressuposto de que se a história comporta rupturas, ela é também continuidade e nessa continuidade ela amplia horizontes de compreensão que reformulam ações e comportamentos.

No terceiro capítulo, D. Fragoso e o Processo de Construção dos Novos Sujeitos da História, procuro, a partir da retomada da trajetória de D. Fragoso, compreender sua ação em Crateús: até que ponto sua ação e suas opções foram fundamentais para a construção de uma Igreja comprometida com os pobres. Desde sua nomeação como bispo auxiliar de São Luiz, sua prática pastoral esteve voltada para os segmentos mais pobres. Nesse período coordenou a ACO (Ação Católica Operária), participou do Concílio Vaticano II e, durante o Concílio, articulou-se com os bispos e cardeais que priorizavam uma Igreja encarnada, comprometida com os pobres e os mais sofridos. Analiso, com Gonçalves (2005, p. 119), se a sua ação mais radical na diocese de São Luiz teria sido responsável por sua nomeação para Crateús. O natural seria sua nomeação para a Diocese de São Luiz, em substituição ao titular, D. José Medeiros Delgado, que estava para assumir a Arquidiocese de Fortaleza, mas sua postura de defesa dos pobres e de uma Igreja comprometida com as lutas sociais, o teria levado para Crateús. Como veremos nesse capítulo, sua nomeação para uma diocese do interior, recém-criada foi uma punição, o ostracismo para uma figura que começava a ser incômoda. Só que sua personalidade forte assentada em 
compromissos firmados ao longo de sua vida religiosa logo colocou Crateús como modelo de Igreja comprometida.

É interessante destacar a personalidade de D. Fragoso, uma personalidade forte, até certo ponto, intransigente, que afirma, desde o início, qual seria sua postura frente à Igreja de Crateús. Em vários momentos soube retomar seu caminho e se apoiar nos fiéis e nos seus auxiliares diretos para caminhar com os passos do povo e a partir das ansiedades, inseguranças e recuos do próprio povo dos movimentos e das CEBs, sem se entregar ao desânimo nem arredar do caminho traçado no primeiro momento. Seu governo, à frente da Diocese, foi inovador. Sua figura foi fundamental no processo de construção de solidariedades e de luta pela libertação e pelos direitos cerceados. Sem ele não sei se haveria uma Igreja de Crateús, se haveria uma Igreja encarnada na história, protagonista de lutas políticas e sociais. Nesse capítulo, portanto, procuro responder se haveria uma Igreja comprometida e assentada em comunidades eclesiais de base, comunidades constituídas de sujeitos, em Crateús, sem a figura carismática e forte de D. Fragoso.

No quarto capítulo, As Comunidades Eclesiais de Base e a Política em Crateús, faço uma análise das Comunidades Eclesiais de Base tendo como premissa que as mesmas são espaços públicos da política, espaços organizados pela Igreja Católica com a participação dos trabalhadores urbanos e rurais, com a preocupação de inseri-los no contexto nacional, como sujeitos que procuram definir pautas, afirmar direitos, participar nas definições das políticas públicas; tudo isso a partir de um processo de descobrimento do real, das contradições do real, do processo sociopolítico e econômico que marginaliza e cria a pobreza. As Comunidades Eclesiais de Base são espaços educacionais, espaços em que a educação dos seus membros se dá através de um processo de discussão aberta e democrática, mediada pela realidade que se descobre opressora por cercear aos segmentos populares a possibilidade de conhecer e atuar na definição de sua realização como homens e mulheres livres, autônomos, capazes de, por isso mesmo, definir seus destinos. 
O quarto capítulo estará focado no desenvolvimento das Comunidades Eclesiais de Base na Diocese de Crateús, nas dificuldades encontradas na instalação de um modelo de Igreja que incorpora a ação dos leigos, ação que não se conforma em reproduzir as relações de dominação existentes, mas que pretende romper com o conformismo que leva os pobres a se submeterem aos interesses econômicos e políticos das elites. É um caminhar pautado em dificuldades, em superações e no conflito constante com as elites e seus prepostos. Não se pode esquecer que a nomeação de D. Fragoso para Crateús ocorre no mesmo ano em que se instala a ditadura militar no País. Na medida em que a ação pastoral de D. Fragoso avança, na medida em que ela multiplica o número de Comunidades de Base, na medida em que em seu avanço descobre os mecanismos de dominação e reprodução da pobreza, na medida em que estes problemas são colocados e afrontados, a repressão procura coibi-lo com prisões e a instalação de inquéritos numa tentativa clara de calar as lideranças e os membros de CEBs, de restringir sua ação, de recolocar o trem nos trilhos do silêncio e do medo.

Não se pode esquecer que a ação de $D$. Fragoso acontece durante a ditadura, em um momento de suspensão dos direitos civis, numa cidade que tinha uma presença incômoda para uma ação dessa natureza, que era a existência em Crateús de um Batalhão de Engenharia do Exército Brasileiro. Nesse caso, a autoridade máxima, a autoridade que se sobrepunha as demais, civis e religiosas, era a autoridade militar, arbitrária tanto quanto 0 regime que instalou no País. No capítulo em pauta verificaremos que a presença do exército, amedrontava, mas não paralisava a ação dos católicos de CEBs e várias vezes o conflito se instalou e lideranças católicas, inclusive padres foram presos. Reconstruir esse percurso é revigorante como o é, também, perceber que as CEBs não são mais as mesmas, mas continuam como instrumentos que despertam e estimulam a presença política das camadas populares na Diocese de Crateús. Como diz Padre Machado: sobrevive o jeito de ser CEBs. É esse jeito de ser CEBs que sobrevive nos 
sindicatos, na Escola Família Camponesa D. Fragoso de Independência, nos assentamentos etc.

Nesse capítulo procurei, também, verificar a presença de lutas significativas por terra, trabalho e direitos, por espaços de organização e pressão, pela construção de espaços públicos da política já que a redemocratização, de modo brando em algumas situações e de maneira violenta em outras, tentando assim suprimir esses espaços inviabilizando, através de mecanismos institucionais, a organização livre e autônoma dos trabalhadores. 


\section{CAPÍTULO I}

\section{DEBATE PRELIMINAR}

\subsection{Trabalhadores rurais e Igreja, as razões da minha escolha}

No início da década de 1980 eu, entre outros, estávamos envolvidos com a organização do Partido dos Trabalhadores em algumas cidades do sul do estado do Ceará. Era necessário que conseguíssemos organizar 16 diretórios municipais no estado para que o PT pudesse ter reconhecimento legal. Cabia a mim e a alguns companheiros a tarefa de instalar pelo menos seis diretórios na região do Cariri. Assumi essa tarefa com alguns amigos ligados à diocese do Crato e ao movimento sindical dos trabalhadores rurais. Essa, se não era a única categoria organizada no Cariri, era a categoria organizada com maior inserção política e, portanto, aquela que procuramos para apresentar e discutir a proposta da criação do Partido dos Trabalhadores. Fomos bem recebidos e a organização dos diretórios municipais pôde ocorrer em seis dos nove municípios que contatamos.

A população rural ainda era significativa, o controle que era exercido pelo sindicato rural junto às bases rurais era abrangente na medida em que as aposentadorias passavam por ele, a assistência médica e odontológica da população rural era realizada através desses sindicatos da mesma maneira que a assistência jurídica, por menor que fosse, era prestada a partir dos sindicatos que mediavam as questões com os proprietários de terra e asseguravam direitos trabalhistas para esse segmento da população dos municípios.

Essa força dos sindicatos dos trabalhadores rurais tinha a ver, também, com as secas e as frentes de serviço, ou a "emergência" como se costumava chamar. Essas eram atividades que mantinham a população em seus locais de moradia e, desse modo, mantinham as relações de poder e de produção em condições de continuidade nos anos normais. Não se desarticulavam, 
não sofreriam com a falta de mão-de-obra necessária às atividades normais do campo. Os sindicatos eram importantes primeiro porque pressionavam os governos pelas frentes de serviço, garantindo desse modo a sobrevivência das populações rurais; em segundo lugar porque procuravam garantir vagas para a maioria dos trabalhadores, com isso renda; depois, por garantirem condições adequadas de trabalho; e, finalmente, pressionavam para que as obras de infraestrutura que eram realizadas pelos rurais se localizassem nas áreas em que se concentrava maior quantidade de famílias.

Períodos de seca sempre foram momentos em que a população rural ficou mais susceptível, mais fragilizada. Nessas condições, os proprietários de terra não tinham como atender às demandas urgentes dos trabalhadores, moradores e parceiros. A saída era sempre o sindicato que se transformava em canal de negociação e pressão sobre os políticos e os proprietários que receavam desorganizar a produção nos anos de inverno normais. Ainda havia as culturas do algodão, o gado e a cana de açúcar que precisavam ser tocadas.

Também se deve considerar que os sindicatos dos trabalhadores rurais possuíam uma rede de delegacias sindicais no campo que acompanhavam o dia-a-dia dos trabalhadores rurais e dos pequenos produtores. Através delas, eles se sentiam seguros, compartilhavam os problemas e buscavam soluções coletivas. Não se sentiam isolados, participavam de um conjunto que tinha força suficiente nos momentos das disputas e que os amparavam quando necessitavam de cuidados médicos, odontológicos e jurídicos. As categorias urbanas não dispunham de uma rede de assistência que se equiparasse a essa. Sendo assim os rurais se sentiam devedores dos seus dirigentes. É claro que a força política que esses detinham era fundamental nos processos eleitorais, decidiam que candidato de que partido assumiria a vaga de prefeito, vereador e de deputado, dentre outros cargos em disputa nas eleições oficiais. Desse modo, as disputas internas para a escolha das direções sindicais envolviam políticos e partidos políticos, equivaliam a uma prévia das eleições municipais. 


\title{
1.2. A Diocese do Crato e o Sindicato de Trabalhadores Rurais.
}

Mas a força dos sindicatos da região cearense do Cariri não estava apenas aí, estava também na Igreja. Foi a Diocese do Crato que em 1962 instalou os primeiros sindicatos na região, eram cinco sindicatos com base em vários municípios para fechar qualquer possibilidade de fundação de sindicatos que não fossem tutelados por ela. Esse comportamento da Diocese estava associado ao movimento nacional promovido pela Igreja Católica para organização dos trabalhadores rurais, ela não queria perder sua influência sobre a população rural como tinha, ou acreditava ter perdido sua influência sobre as populações urbanas. Havia uma disputa entre o Partido Comunista do Brasil, as Ligas Camponesas ${ }^{7}$ e a Igreja, essa disputa se acirra quando aparece, no horizonte, a criação da CONTAG.

Segundo Martins:

\begin{abstract}
"Parece que a partir de 1962 a Igreja começou a disputar também a possibilidade de ter o controle da Confederação dos Trabalhadores Agrícolas que viesse a ser fundada, passando a concorrer diretamente pelo controle do movimento camponês pela cúpula. Promulgada a legislação trabalhista em 1963 os diferentes grupos empenharam-se no reconhecimento dos seus sindicatos junto ao Ministério do Trabalho, tendo a Igreja, no segundo semestre de 1962, feito uma tentativa de criar e controlar uma Confederação para evitar que o Partido Comunista o fizesse." (1995, p. 87)
\end{abstract}

Criar federações estaduais se tornou uma meta dos movimentos sociais e das instituições (Igreja, Partido Comunista Brasileiro e Ligas Camponesas). Mas, para criá-las era necessária a existência de pelo menos cinco sindicatos, o que explica a urgência da Diocese do Crato para criar os cinco sindicatos que criou em 1962, no Cariri.

Essa preocupação faz com que a Arquidiocese de Natal, no Rio Grande do Norte, inicialmente crie o Serviço de Assistência Rural e depois mobilize a

\footnotetext{
${ }^{7}$ Elide Rugai Bastos fala das Ligas Camponesas como entidade de direito privado com o intuito de defender os trabalhadores do campo, especificamente os moradores e parceiros. O nome de Liga tem sua origem nas formas de organização dos trabalhadores do campo encontradas pelos comunistas para burlar as formas legais de representação.
} 
fundação de sindicatos de trabalhadores rurais. Da mesma maneira, em Pernambuco, começa-se toda uma mobilização para a criação de sindicatos rurais tendo à frente o Padre Crespo e outros religiosos. Nessa época, segundo Cruz (1985), além desses dois estados, a Igreja cria equipes de sindicalização nos estados da Paraíba, Bahia, Alagoas, Piauí, Sergipe, Maranhão. Fica de fora apenas o estado do Ceará. Neste caso, apenas na região do Cariri a Diocese do Crato se sente obrigada a fundar os sindicatos rurais, acredito, pela proximidade fronteiriça com os estado de Pernambuco e Paraíba, espaço privilegiado das Ligas Camponesas.

Foi através de Natal que o bispo diocesano do Crato, D. Vicente de Araujo Matos, espelhou-se para criar a Fundação Padre Ibiapina, entidade da diocese voltada para a ação diocesana principalmente no campo. Sua função era ministrar cursos profissionalizantes, cursos sobre sindicalismo, preparar lideranças para as atividades sindicais, acompanhar e coordenar as ações da diocese em seu trabalho pastoral, e nela a Escola de Líderes Rurais, principalmente voltada para o acompanhamento e assessoramento dos sindicatos de trabalhadores rurais. Através da Fundação Padre Ibiapina a ação da Diocese do Crato se intensifica, principalmente na zona rural. Sua ação era voltada para a melhoria das condições de vida do homem do campo, compreendia como toda a Igreja Católica no Brasil, que havia possibilidades de deter a propaganda anticapitalista dos comunistas. Como acentuou Martins:

"A Igreja entrou na questão agrária através da pastoral de D. Inocêncio, por uma porta extremamente reacionária. Aquela pastoral nasceu numa reunião de fazendeiros, padres e professores rurais e não numa reunião de camponeses e trabalhadores rurais. A preocupação era com a agitação que estava chegando no campo, com a possibilidade da Igreja perder os camponeses, como tinha perdido os operários. A questão era desproletarizar o operário dos campos, evitar o êxodo que levava os trabalhadores para a cidade e os tornava vulneráveis à agitação e ao aliciamento dos comunistas, como assinalaram outros documentos produzidos por outros membros do episcopado." (1995, p. 88) 
Para a Igreja, a melhoria das condições de trabalho e produção, a assistência à saúde, a efetivação de direitos trabalhistas e a educação para os trabalhadores rurais seriam elementos importantes para evitar que os camponeses se deixassem envolver pelos marxistas, defensores de uma sociedade de iguais, inteiramente laica, centrada no homem e nas suas necessidades.

Sendo assim, em oposição, a Igreja defende o liberalismo e a sociedade capitalista, acredita que nela existem as possibilidades de superação da pobreza absoluta através do trabalho e do esforço de cada um. $O$ investimento privado ou estatal é responsável pela criação de locais de trabalho, postos de trabalho que, ocupados, irão permitir a todos a capacidade de suprir suas próprias necessidades.

Essa ideologia disseminada no Brasil a partir do final dos anos de $1940^{8}$, apregoando que o capitalismo em si não era responsável pelas mazelas que atingiam as populações dos países periféricos, chegou através de organismos internacionais, principalmente norte-americanos, assentada na idéia de que maior participação da população poderia evitar as diferenças econômicas e a exploração sobre o trabalho. Afinal esse tipo de exacerbação da exploração não era uma característica própria do capitalismo, mas era fruto da ganância de alguns capitalistas, se alguns controles fossem desenvolvidos na sociedade esse perfil selvagem do capitalismo poderia ser controlado e ele poderia trazer melhoria para todos: trabalhadores e capitalistas.

\footnotetext{
8 "Institucionalizado pela ONU após a II Guerra Mundial o Desenvolvimento de Comunidades é postulado num momento histórico que as grandes potências - lideradas pelos Estados Unidos e Rússia - deflagram a chamada "guerra fria" pela conquista do primado político, econômico e ideológico de um mundo supostamente bipolarizado." (AMMANN, Safira. Ideologia do Desenvolvimento de Comunidade no Brasil. Editora Cortez, 2003, p. 29) Na apresentação Ammann, se referindo ao Brasil irá dizer: "Durante os anos 1950 adotam-se os modelos norte-americanos pautados em supostos de harmonia e equilíbrio, que objetivam solucionar 'o complexo problema de integrar os esforços da população aos planos regionais e nacionais de desenvolvimento econômico e social.' $O$ Desenvolvimento de Comunidades afirma-se como instrumento capaz de favorecer o consentimento espontâneo e a adesão das classes subordinadas às Políticas Sociais definidas pelo Estado." (idem, p. 9)
} 
Para aqueles que defendiam, como a Igreja Católica, essa ideologia de que o progresso chegaria para todos, trabalhadores e burgueses, o desenvolvimento das comunidades era fundamental. Somente através da organização das comunidades e dos controles que esse tipo de organização permitiria criar, poder-se-ia ter um capitalismo mais humano e progressista, o que significava emprego e renda para todos assentados na comunidade. Comunidade cooperativa de proprietários e trabalhadores mediada pelo Estado e a Igreja.

A partir daí, seguindo a linha de interpretação do processo histórico dos anos de 1950 e de 1960 adotada por Ammann (2003) e Ricci (1999), a Igreja Católica, financiada pelos governos brasileiros desde Getúlio Vargas, passando por Juscelino Kubitschek, Jânio Quadros e João Goulart, passou a atuar mais incisivamente na sociedade. A Igreja era uma instituição, talvez a única no Brasil, que estava presente em todos os estados da federação e em todos os municípios brasileiros por meio de suas paróquias, de suas dioceses, padres, religiosas e leigos. Sua preocupação era com a expansão comunista que ameaçava sua existência como instituição, pois pregava o marxismo ateu ao mesmo tempo em que apregoava a associação da Igreja com os interesses dos ricos, fez com que recebesse a incumbência de, aproveitando sua rede de padres e a fé do povo simples, atuar em favor de um capitalismo humano, menos desigual e capaz de suprir as necessidades do povo.

O desenvolvimento, apregoado, passava necessariamente pela constituição de comunidades, pois todos os brasileiros seriam beneficiados por ele e todos participariam de sua construção. O desenvolvimento deveria ter como base a comunidade, entendida como espaço de relações iguais entre trabalhadores e burgueses, afinal, como Ammann deixa entrever em sua análise, é nos pequenos burgos que ele deve começar, onde as relações são mais humanas, as pessoas se conhecem e sabem de suas carências comuns. 
Dessa forma, emergem conceitos fundamentais para justificar a ação da Igreja. Esta ação da Igreja junto aos programas de desenvolvimento de comunidades se justifica pela participação de todos na resolução dos problemas comuns e principalmente por objetivar a melhoria das condições de vida da população. Desenvolvimento humano significa, na doutrina da Igreja, educação, saúde, emprego, renda e cooperação entre os homens, irmãos na Igreja.

A Diocese do Crato, como tantas outras, assimila e assume essa postura que aparece como imbuída do espírito cristão da fraternidade e da caridade. Assim, através da Fundação Padre Ibiapina, procurava agir no meio rural discutindo os direitos trabalhistas, as condições de vida da população rural e promovendo discussões sobre a modernização do campo que permitisse aos trabalhadores salário e renda. Exemplo disso é o Seminário para o Desenvolvimento do Sul Cearense ${ }^{9}$ que ocorreu em 1961, com o patrocínio da Diocese. A partir dele, a Diocese cria a Faculdade de Filosofia do Crato, para formar professores capazes de melhorar o nível de educação do povo; cria os sindicatos dos trabalhadores rurais com o objetivo de competir com o PCB, mas também para criar canal através do qual os trabalhadores pudessem requerer direitos; fez cursos de liderança e sindicalismo; promoveu a instalação de mini-postos de saúde na zona rural; promoveu a educação de base através das escolas radiofônicas coordenadas pelo MEB; e tantas outras ações, inclusive na área profissional, como formação de costureiras.

Desse modo, a ação da diocese do Crato já chamava a atenção de todos. No entanto, sua ação era vista pelos segmentos de esquerda como conservadora, principalmente após o golpe militar. Era difícil, inclusive para os trabalhadores e suas lideranças formadas pela própria Diocese, o apoio que a mesma deu ao golpe militar. Anteriormente ela afirmava a democracia

\footnotetext{
${ }^{9}$ O Seminário para o Desenvolvimento do Sul Cearense, ocorrido no ano de 1961, tinha como objetivo promover o desenvolvimento do Cariri Cearense, para tanto fez um levantamento das carências e dos entraves ao desenvolvimento regional a partir do qual pleiteia a educação superior, investimento na modernização das usinas de beneficiamento de algodão, modernização dos engenhos de rapadura permitindo a produção de álcool etc.
} 
na medida em que promovia as comunidades a partir de processos de discussão e de tomadas de decisão sempre com a participação de todos os envolvidos. Ela discutia direitos, e os direitos foram suspensos, mas mesmo assim, continuava respaldando e justificando o Estado força da ditadura militar.

A minha preocupação com os sindicatos dos trabalhadores rurais aparece quando, na segunda metade de 1979 e início de 1980, estive à frente do movimento de criação de comissões provisórias pró-criação do Partido dos Trabalhadores no Cariri e, depois, na organização dos diretórios municipais do mesmo partido. Nessa época, eu contava com a ajuda de alunos da Faculdade de Filosofia do Crato que eram membros da equipe da Escola de Líderes Rurais da Fundação Pe. Ibiapina e de pessoas que eram ligadas à Delegacia da Federação dos Trabalhadores Rurais do Ceará - FETRAECE. Com eles, me aproximei dos sindicatos dos trabalhadores do Crato e de mais oito municípios (Milagres, Nova Olinda, Santana do Cariri, Barros, Brejo Santo, Assaré, Campos Sales e Potengi) e tomei conhecimento de que todos esses sindicatos haviam sido fundados a partir da ação da Fundação Padre Ibiapina, mais especificamente, a partir da Escola de Líderes Rurais ELIRUR.

Nessa escola eram discutidas as condições de vida dos trabalhadores rurais e havia a preocupação com a formação de lideranças rurais; cursos eram ministrados sobre a legislação trabalhista e sindical e dava-se acompanhamento ao trabalho desses sindicatos: suas lutas, sua organização interna, as questões trabalhistas mais freqüentes, questões que envolviam a terra e a formação política das lideranças e das bases.

O trabalho desenvolvido era interessante porque, mesmo se tratando de questões do homem do campo, não deixava de lado a questão da lgreja e do seu papel no processo de organização dos trabalhadores. Os membros da ELIRUR estavam preocupados com o papel político da lgreja e questionavam, juntamente com os trabalhadores rurais, as posições 
assumidas pela diocese do Crato. Esta questão, inclusive foi um dos pontos que gerou, já em 1981, o rompimento dessa equipe com a Diocese, possibilitando a criação da Associação Cristã de Base.

Quero, no entanto, esclarecer que me surpreendia a ação da Igreja. Aliás, o que me surpreendia não era propriamente a ação da diocese enquanto Igreja, mas a presença de jovens, homens e mulheres envolvidos em um trabalho político, trabalho que extrapolava a ação propriamente sindical, todos formados por essa Igreja reconhecida como tradicional e conservadora. Isso me inquietava e procurava respostas para a ação dos agentes da Diocese que ultrapassava os limites impostos por esta. Claro que eu conhecia, superficialmente, as teses discutidas no Concílio Vaticano II, de uma Igreja pobre e comprometida com os pobres, e a renovação que ele provocou no catolicismo, principalmente na América Latina.

Mas sabia também das características próprias do bispo diocesano, conservador e comprometido com a ordem capitalista e da autonomia que os bispos gozavam em suas dioceses. Como então esses jovens, homens e mulheres, se contrapunham à ação e aos princípios religiosos e políticos que a respaldavam e emanavam da Diocese? Como eles continuavam no interior da diocese se faziam um trabalho educativo junto às bases camponesas que criticavam a ação dessa Diocese? O que os respaldava nessa ação crítica e política? As diretrizes emanadas do Concílio Vaticano II? A presença em outras dioceses de religiosos imbuídos do espírito Conciliar? A própria repercussão que o Concílio Vaticano II teve na sociedade civil, entre religiosos e povo? E a ditadura?

\subsection{Crateús, a Igreja Progressista e os Trabalhadores.}

Com essas questões minha curiosidade voltou-se para as Igrejas que eram progressistas, como a de Crateús. Era minha intenção nessa época analisar a ação da Diocese do Crato tendo como parâmetro a Diocese de Crateús, trabalho que não foi possível realizar e que agora retomo, claro que a partir 
de outras questões que depois esclarecerei. De qualquer maneira restava a curiosidade com relação às Igrejas progressistas ${ }^{10}$, aquelas que se comprometeram com a causa dos mais pobres, que passaram a discutir a questão da pobreza no capitalismo, principalmente nas sociedades do chamado terceiro mundo, dentre elas os países da América Latina. Para tanto, recorreram à sociologia, principalmente a sociologia marxista como teoria que explicava as contradições inerentes ao modo de produção capitalista, e se aproximaram de segmentos da esquerda com os quais começaram a dialogar. Para eles, a pobreza somente poderia ser superada superando-se o capitalismo como forma de organização da produção e da sociedade.

No contexto da Igreja considerada de progressista, a questão da classe e da luta de classes se colocava de maneira bastante clara: os interesses eram antagônicos, não havia como superar o capitalismo sem acabar com propriedade privada e, consequentemente, acabar com as classes sociais. $O$ processo de organização dos trabalhadores deveria, portanto, resultar num processo de luta e de avanço da inserção dos trabalhadores na sociedade, deveria transformá-los, nesse caso, em protagonistas de sua própria história. Cabia à Igreja e às outras forças políticas e sociais de esquerda apoiar os trabalhadores em sua luta pela libertação, dando-Ihes, ou despertando-os para os instrumentos com os quais e a partir dos quais poderiam chegar à superação do modo de produção capitalista, com suas mazelas, dentre elas a pobreza, a ausência dos direitos e a falta dos canais institucionais que permitissem a participação de todos nas decisões políticas e administrativas.

Para compreender que a Igreja não era um todo, único e indivisível, conservadora por inteiro, foi necessário que me defrontasse com os agentes

\footnotetext{
${ }^{10}$ Utilizo, para distinguir os segmentos da Igreja entre progressistas e conservadores, a análise de Follmann em seu livro: Igreja, Ideologia e Classes Sociais. Para esse autor, são progressistas os religiosos e religiosas, que afinados com o Vaticano II, comprometeram-se com as lutas populares por direitos e cidadania, enquanto entende que os conservadores são aqueles que procuram manter a Igreja longe das questões políticas. Para estes, não é papel da Igreja intervir na sociedade, seu papel é eminentemente religioso. Essa visão é compartilhada por todos os religiosos e religiosas que estão envolvidos com o processo de organização dos segmentos populares. Para maior compreensão, veja Follmann, p. 29 e 30
} 
da Escola de Líderes Rurais que, com sua ação, demonstravam que mesmo na Igreja tida como conservadora há brechas para a discussão mais radical sobre o papel da Igreja e sobre sua inserção na sociedade em defesa dos mais pobres. Não havia teoria, havia uma ação que decorria da posição de origem desses jovens e adultos, na maioria de famílias camponesas, que por sua situação percebiam claramente a submissão de seus interesses aos interesses dos segmentos dominantes. Eles percebiam claramente que não havia como conciliar interesses de segmentos opostos por sua posição objetiva no processo de produção. A meação, a parceria, a moradia e o assalariamento temporário revelavam claramente que os interesses dos camponeses não poderia ser igual aos interesses dos proprietários de terra. Da mesma maneira percebiam que o processo de comercialização, dos seus produtos, os opunha aos atravessadores: sem meios de transporte para levá-los às feiras, sem espaço para armazenarem seus produtos e protegêlos dos insetos é motivo pelo qual acabavam por vender na safra para comprarem depois na entressafra, bem mais caros.

A fundação dos sindicatos, mesmo aqueles que foram criados pela Igreja considerada conservadora, reuniu trabalhadores do campo, colocava-os diante um dos outros, permitia a discussão tendo em vista a realidade de cada um que acabava por ser a realidade de todos, confrontava com outras realidades através de encontros regionais, nesses encontros confrontavamse visões e concepções de mundo e da realidade, fazendo-os perceber que a realidade que se vivia era opressora e que mudá-la era uma tarefa urgente a ser encetada por eles próprios.

A própria Igreja, a partir do Concílio Vaticano II, de Medellin () e Puebla (), levanta de maneira mais clara a situação do homem pobre do terceiro mundo e indica que os males de que padecem essas populações decorrem do modo de produção capitalista, do imperialismo e do colonialismo seus filhos diletos (), tão necessários ao processo de acumulação e concentração da riqueza nas mãos dos burgueses do primeiro mundo. A linguagem da Igreja aproximou-se da linguagem dos marxistas, não se podia questionar a 
situação dos países considerados subdesenvolvidos, conceito que se discute hoje, mas importante na época por colocar a questão fundamental da dependência e da submissão dos países periféricos em relação aos países centrais, sem levar em conta as relações estabelecidas mundialmente pelo capitalismo em expansão. Portanto, para a Igreja, principalmente a Igreja progressista, não havia mais como discutir 0 desenvolvimento e 0 desenvolvimento de comunidade sem levar em consideração a oposição de interesses e as contradições inerentes ao desenvolvimento do capitalismo. A questão não estava na forma como os capitalistas, alguns deles, usavam 0 capital em benefício próprio e em detrimento dos demais, não era o egoísmo inerente a alguns agentes do capital, mas era própria ao processo de desenvolvimento do capital, era da sua essência promover a concentração da riqueza de um lado e aumentar a pobreza do outro, acabar com a pobreza só era possível na medida em que se superava o capitalismo como modo de produção predominante.

A análise realizada a partir do Concílio Vaticano II, de Medellin e de Puebla, acabou por chegar aos católicos de todas as dioceses via cursos, documentos discutidos em reuniões e encontros regionais e nacionais. Chegou através do Movimento de Educação de Base (MEB), contagia o movimento sindical dos trabalhadores rurais e, a partir daí, se questionou a posição das dioceses e padres que ainda propagavam a complementaridade das classes sociais, dos interesses comuns e da formação de comunidades centradas nos interesses que são comuns e complementares, independentes da existência ou não de classes antagônicas em seu interior.

Analiso o processo de construção de uma visão mais à esquerda na diocese do Crato a partir dessa interação constante com outros segmentos das Igrejas Católicas alinhadas com o Concílio Vaticano II, no embate com os segmentos de esquerda, no processo de criação de uma estrutura sindical rural assentada nas federações estaduais e na confederação nacional. Também foram importantes para a formação mais crítica dos trabalhadores no Cariri a Ação Católica Especializada e as aulas radiofônicas promovidas 
pela diocese. A Diocese era afiliada ao Movimento de Educação de Base, MEB, que seguia a pedagogia de Freire para a qual educação e conscientização andavam juntas.

É interessante abrir um parêntese para posicionar o MEB no contexto da Igreja Progressista. Sua estrutura foi questionada pela Diocese de Crateús por não atender aos interesses dos segmentos sociais populares nos quais tinha inserção e por não representar, na sua estrutura centralizada, a posição de uma Igreja fermento do povo em sua caminhada em direção a libertação. Mas, não se pode ignorar a análise realizada por Emanuel de Kadt (2007) que posiciona o MEB como organismo que abriu, em sua ação educativa, espaço para os, chamados por ele, católicos radicais ${ }^{11}$, entre os quais as lideranças camponesas e sindicais do Cariri.

$\mathrm{Na}$ época, ao analisar o processo por que passou o conjunto das lideranças sindicais e os membros da equipe da ELIRUR da Fundação Pe.lbiapina, no questionamento da realidade camponesa e da ação da Diocese, longe dos novos princípios emanados do Concílio Vaticano II, Medellin e Puebla, posicionam-se à esquerda e passam a atuar através de novos mecanismos institucionais, como a Associação Cristã de Base, o Partido dos Trabalhadores e a Central Única dos Trabalhadores, assumindo a Igreja renovada pelo Concílio, a partir de uma nova visão do leigo, perguntava-me como deveria se encontrar o processo de organização dos trabalhadores numa diocese que assumia a Igreja chamada progressista.

Não se pode esquecer que a Igreja Católica é uma instituição com ampla penetração nos segmentos populares, com uma rede de paróquias, igrejas e capelas que se espalhavam em todo o território nacional, com a presença de padres, religiosos e religiosas, senão em todas elas, mas na maioria, com colégios e práticas catequéticas que abrangiam basicamente muito mais do

\footnotetext{
${ }^{11}$ Quando Kard se refere aos católicos radicais está, segundo ele mesmo, se referindo aos segmentos da Igreja, religiosos ou leigos, que atuam no meio popular a partir de uma concepção de Igreja comprometida e viva: uma Igreja encarnada nos meios populares, voltada para a inserção cidadã dos segmentos populares.
} 
que a metade da população brasileira, centenariamente com seu arsenal doutrinário absorvido através das missões por parte significativa da população rural $^{12}$, num país em que as instituições laicas eram insuficientes, incapazes de exercerem controles e promoverem mobilizações nacionais, a Igreja era talvez o único elemento de unidade, afinal através desses elementos apontados era ela que exercia a hegemonia e somente através dela pôde o Estado não-monárquico exercer sua hegemonia nacional.

O Estado republicano rompe com ela, mas dela se utiliza para manter a unidade e as populações sob controle, tanto que em nenhum momento conseguiu fazer valer nas instituições educacionais uma educação realmente laica. Portanto, acreditava-se, naquele momento, fazer mudanças nas estruturas econômicas, sociais e políticas no país passava necessariamente pela Igreja, pelas formulações e representações elaboradas por ela, afinal suas ramificações na sociedade civil, e o nível de aceitação que ela detinha permitiam que tais formulações e representações fossem assumidas pela sociedade. Sem ela não havia como mudar, sem seu papel educativo não haveria de se mudar facilmente as estruturas de poder vigente. A idéia era a de que sem a presença do Estado, a única via de acesso dos pobres do campo aos serviços era através dos senhores da terra, mas a Igreja, com sua rede de intelectuais próxima do povo poderia ser uma via de mudança política substancial. Diante disso, uma Igreja que rompesse com a estrutura de poder vigente, poderia e era uma força a combater, e foi combatida, pois sua presença, sua força popular, poderia levar ao rompimento da legalidade burguesa.

Supunha, portanto, que na Diocese de Crateús a organização dos trabalhadores estava mais avançada, acreditava que as lutas encetadas naquela Diocese fossem mais incisivas e que o processo de conscientização atingia todos os segmentos, a percepção do capitalismo com a exploração do trabalho estivesse mais clara. Que a leitura da mensagem fundadora do

\footnotetext{
${ }^{12}$ Ribeiro (...) faz uma análise das missões e de seu significado no processo de incorporação do cristianismo romano a partir de algumas figuras mais carismáticas da Igreja Católica no meio rural de predominância de um catolicismo popular livre das injunções da Igreja oficial.
} 
cristianismo $^{13}$ fosse um instrumento de libertação, que impulsionasse a população em direção a uma sociedade sem classes. Mas, era necessário que essa igreja se articulasse com as outras, se constituísse num elemento de mudança, que contaminasse religiosos e leigos das outras dioceses, que fomentasse o inconformismo, não que ela se transformasse em partido, que ela se laicizasse, mas que ela fosse 0 instrumento de educação libertadora até porque assentada numa mensagem de libertação agora entendida como social e política para ser religiosa. Da conscientização promovida pela Igreja Progressista, a partir da leitura que fazia da doutrina da revelação, se chegasse à doutrina da libertação política e social.

Isso não significa a criação de um partido religioso, católico, mas de fomentar, entre os leigos, a política, de modo a superar a ordem constituída. Não que ela voltasse a se posicionar como nos anos de $1930 \mathrm{com}$ a Liga Eleitoral Católica ${ }^{14}$, mas que ela formasse cristãos empenhados numa ação política de promoção do homem na direção de uma sociedade justa, sem explorados e exploradores.

Essa era aparentemente a opção expressada pelas ações e falas de D. Fragoso desde sua posse quanto confronta seu modelo de Igreja com aquele que predominava então e que emanava da ação de $D$. Tupinambá da Frota, bispo de Sobral, até sua aposentadoria. A Diocese de Crateús foi formada a partir de oito municípios oriundos dessa Diocese, portanto, ainda sob a influência da pastoral de D. Tupinambá. Segundo o próprio D. Fragoso, a população média e os ricos e poderosos de Crateús esperavam dele uma pastoral semelhante. Desde o início ela repudia o modelo de

\footnotetext{
${ }^{13}$ Para Follmann, a mensagem fundadora de uma religião é constituída por um conjunto de normas e crenças que estabelecem seu espaço e a distingue das demais, é a base sobre a qual e para qual se voltam os fiéis quando se afirmam ou afirmam uma religião. Para ele a mensagem fundadora que está na origem das religiões permitem visões diferenciadas, leituras diversas e práticas até mesmo opostas decorrentes da posição social que ocupam os seus membros na estrutura de poder em uma determinada sociedade. Veja as páginas 34 e seguintes.

${ }^{14}$ A Liga Eleitoral Católica - LEC - propunha reunir os católicos em torno de políticos que expressassem os interesses da Igreja Católica, que lutassem pela implementação do catolicismo como religião oficial, favorecida pela lei, pela obrigatoriedade de seu ensino nas escolas públicas. Veja a respeito Parente, Josênio: Anauê, os camisas verdes no poder.
} 
Sobral, que era também o modelo da diocese do Crato, e afirma um modelo consonante com o Concílio Vaticano II, de uma Igreja pobre, voltada para os pobres, uma Igreja que levantasse a bandeira da justiça social, da equidade e da libertação dos homens da opressão a que estavam submetidos pelo capital, da desumanização.

Em seu primeiro discurso, em praça pública, pronunciado na presença de autoridades políticas, religiosas e militares, em plena vigência da ditadura militar, D. Fragoso marcou sua posição deixando claro quais seriam as diretrizes que nortearam sua ação diocesana. Segundo ele, teria dito:

\begin{abstract}
Agradecia do fundo do coração a homenagem que me faziam. Ao mesmo tempo queria ser sincero e honesto com eles: o bispo de Crateús não seguiria, neste ponto, os passos do querido bispo de Sobral, D. José Tupinambá da Frota. Não seria um construtor de civilização. Não faria faculdade, colégio, hospital, ambulatório. Queria ser, acima de tudo, servidor da consciência dos cristãos de Crateús. A comunidade cristã de Crateús, movida e animada por sua fé, construísse todas as obras necessárias para o destino da cidade. (FRAGOSO, 1982, p. 14)
\end{abstract}

Este foi um momento importante, um momento em que D. Fragoso, diante das autoridades civis e militares, afirmava sua posição, sua visão de Igreja e de sociedade. Ao ler trechos de seu discurso de posse impressionaram-me a coragem, o destemor, o compromisso com os desvalidos e a sua visão de história, a clareza que tinha de que a libertação do homem, homem que era oprimido, só poderia vir através de suas próprias mãos e que a Igreja Católica tinha um papel fundamental nesse processo. Para ele, não era fazer uma Igreja para o povo, mas fazer uma Igreja com o povo e ao fazê-lo, construir uma sociedade justa. Igreja e sociedade não eram distintas.

Se antes já estava decidido a analisar a inserção social da Igreja reformada, agora, depois de verificar alguns textos escritos por D. Fragoso, minha vontade de apreciar uma diocese renovada aumentou. A importância da Igreja numa sociedade como a brasileira é grande na medida em que essa instituição perpassa toda a sociedade, na medida em que ela teve um papel 
fundamental na formação da nossa gente desde o período colonial, em seu nome se fez a colonização brasileira e em seu nome se submeteu os povos indígenas e negros, ela tinha um papel fundamental na colonização, na formação e na submissão do homem do novo mundo aos interesses coloniais europeus.

Sua rede de paróquias, seus padres e religiosos e religiosas estavam presentes no dia-a-dia das fazendas, das fábricas, das cidades e vilas, sua palavra, sua interpretação da Palavra Revelada, sua autoridade religiosa era capaz de conformar, submeter e também de libertar. O desenvolvimento da sociedade, o desenvolvimento das suas estruturas de produção acabou por gerar contradições, classes sociais e interesses que se opunham, pondo a nu todas as mazelas que esse mesmo desenvolvimento provocava gerando pobreza e riqueza, miséria e abundância, injustiças, desigualdades, permitiu que a Igreja, ou segmentos dela, começassem a questionar seus fundamentos doutrinários e rever ações, afinal a palavra fundadora era de amor, de igualdade, de fraternidade entre os homens.

Uma Igreja renovada, imbuída do espírito do Vaticano II não poderia ser igual a uma Igreja conservadora, que se não pregava a exploração do homem sobre o homem, não questionava as razões da miséria; que se pregava a caridade, não questionava a necessidade da mesma, que dizia que os homens, alguns são afortunados, eram diferentes porque Deus thes deu diferentes talentos e a possibilidade de usá-los em seu benefício, também ninguém era capaz de entender os desígnios divinos, o Plano de Deus somente ele era capaz de conhecer. São práticas diferentes, são visões que articulam práticas diversas com resultados diferentes. $O$ que as distinguia, que mudanças provocaram e quais as conseqüências delas? Essas eram questões que queria resolver, ao mesmo tempo, queria perceber a influência das mesmas na sociedade, na política, na economia. Qual a capacidade de organização que tinha as igrejas conservadora e progressista? Quais as consequências dessas formas de organização no quadro político brasileiro dos anos da ditadura militar e nos anos posteriores 
com a retomada da democracia no Brasil? Que mudanças provocou, o que ficou sedimentado, qual o patamar hoje da participação popular?

Enquanto no Crato se falava de promoção humana, sem defini-la num contexto de libertação, pois por promoção entendia melhorar as condições de existência dos trabalhadores, principalmente os rurais, com garantias de renda, aposentadoria, salários dignos para que uma família pudesse viver com dignidade, a Igreja renovada, em consonância com os princípios emanados pelo Concílio, falava de libertação, de conscientização, de autonomia, direitos, justiça social, sociedade de iguais. Os dois primeiros conceitos fundamentados na pedagogia de Paulo Freire, precisos em sua significação de uma libertação das amarras do capitalismo, do trabalho forçado pela necessidade, da superação da opressão a que o capital submetia o trabalho, da alienação e conscientização com o sentido de percepção da realidade e da ação simultânea pela superação dessa realidade alienante.

Da mesma maneira se apropriaram do método da Ação Católica Especializada, ver, julgar, agir, que a levava para um olhar sobre a realidade, verificar suas contradições, descobrir aquilo que se esconde por trás dessa realidade em consonância com a palavra revelada e agir segundo os princípios emanados dela. A realidade, a exploração, a pobreza, a alienação, a opressão como formas de subjugar o homem, submetê-lo aos interesses de poucos, essa realidade que é espaço de não-vida é matéria para o trabalho de educação que eleve as classes oprimidas, as classes populares, a partir da discussão e debate que envolve todos no desnudamento dessa mesma realidade. A Educação para Libertação de Paulo Freire, a Ação Católica Especializada, o Movimento de Educação de Base e a Ideologia do Desenvolvimento de Comunidades, são elementos para uma compreensão de Igreja diferente daquela dos anos de 1950, uma Igreja apartada da sociedade e da situação em que vivem as populações trabalhadoras. Uma Igreja que estava preocupada unicamente com a salvação dos indivíduos e que via na história apenas a realização da 
vontade divina, se era vontade divina não tinha como intervir, mas apenas consolar e conformar os pobres por sua situação objetiva de miséria, carência e pobreza.

A inserção da Igreja, com exceções oriundas de alguns segmentos que contrapunham à realidade opressora a condição do Cristo salvador, somente ocorre quando se acredita ameaçada pela pregação comunista ateia. Nesse momento, ela passa a disputar os vários segmentos sociais com os marxistas, construindo, no confronto, uma doutrina social que explique a realidade e aponte saídas para a pobreza. Para esses segmentos da Igreja, a pobreza é uma conseqüência do desenvolvimento do capitalismo. No confronto, não apenas começa a enxergar as raízes da pobreza como a procurar saídas para a mesma. Suponho que nesse embate, os católicos, religiosos e leigos, enxergam a necessidade de uma ação leiga que se faz através da Ação Católica, do processo de educação de base, do desenvolvimento de comunidades e da organização sindical. Sua ação não pode se restringir à fala da sua hierarquia, dos seus padres em suas homilias, é necessário, até mesmo como um instrumento de defesa de seus espaços, envolver os leigos nessa ação, educá-los no debate, na discussão, construir alternativas. Mas, mais do que leigos, ela procura agir na formação de quadros ligados aos segmentos que se acredita ameaçados pela pregação marxista: estudantes, operários, camponeses.

É interessante verificar que a ação dos instrumentos apontados acima se permite uma análise mais crítica da sociedade, também permite um olhar mais crítico para dentro da Igreja. Nesse processo, as posições da Igreja são revistas e a sua própria estrutura hierarquizada é discutida. Exige-se a presença do leigo e o leigo exige, em contrapartida, maior participação nas decisões tomadas pela Igreja. Não aceita determinações emanadas de um centro que não tem conhecimento da realidade social dos países, principalmente daqueles da periferia submetidos aos interesses do grande capital internacional. Não aceitam determinações sobre o modo de se viver a fé e, por isso, de acordo com a consciência que emerge dos contatos e 
embates com os demais segmentos políticos e sociais radicalizam a ação e lutam por mudanças estruturais.

Para mim, é nesse embate que são construídos espaços políticos e da política numa sociedade que se mantinha fechada aos segmentos populares. É no embate entre a Igreja e outros segmentos políticos progressistas (comunistas, esquerda do PTB, Partido Socialista, UNE, CONTAG, Ligas Camponesas, movimento sindical das diversas categorias de trabalhadores) que esses espaços políticos foram criados envolvendo a sociedade e promovendo mudanças substanciais na política nacional. É a partir daí que a burguesia nacional associada à burguesia internacional, percebendo a ameaça ao seu poder, apoia a instalação da ditadura militar no Brasil.

\subsection{As Comunidades Eclesiais de Base: uma nova forma de inserção política da Igreja}

É interessante frisar, e acredito que se possa confirmar essa assertiva, que a partir da ditadura e como uma consequência dos embates anteriores, a política como atividade da sociedade civil se sedimenta. Nunca se fez tanta política como no período ditatorial, política com a significação proposta por Hannah Arendt ${ }^{15}$. As Comunidades Eclesiais de Base são um demonstrativo dessa combatividade política, os movimentos sociais, os chamados de novos movimentos sociais, são outra forma de fazer política numa época em que os partidos políticos, como instrumentos da política, foram extintos.

\footnotetext{
15 A significação política a que me refiro remete ao espaço da fala como expressão de visões de mundo que se confrontam e afinam na construção de um senso comum mais elaborado e ampliado na medida em que comporta o outro, o diálogo com o outro. A ditadura militar no Brasil impediu a política a partir dos espaços institucionais (partidos políticos e sindicatos), mas a sociedade civil gerou novos espaços da política, gerou nesses espaços novas falas e novos falantes. Novos espaços da fala e novos sujeitos da fala criando novos mundos, mundos que necessariamente se impõem, se sobrepõem ao estado e a sociedade por ele normatizada. Ver Feltran $(2005$, p. 66, principalmente a nota de rodapé na p. 67) e Telles (1999, p. 65 e 67)
} 
Mas a disputa não ocorre apenas na sociedade como um todo. Os diversos segmentos que se veem representados na lgreja ou que a partir dela se expressam também mudam a visão de Igreja predominante até então. Novas leituras da Revelação são feitas adequando a mensagem da Igreja a este novo tempo da política como expressão dos oprimidos. Muda a Igreja, mas a mudança na Igreja não é simples, é envolta numa série de contratempos em função da força que os segmentos conservadores mantêm em seu interior, reforçada pela força das classes dominantes na sociedade. Mas, mesmo assim, as bases da Igreja conservadora são contaminadas no embate.

Minha hipótese é que, em primeiro lugar, a lgreja é contaminada no embate que trava na sociedade com os segmentos populares e os trabalhadores; depois, que a ditadura se instala para abafar os movimentos populares decorrentes dos embates políticos gerados pelos novos espaços da política, a Igreja se faz um desses espaços; em terceiro lugar, mesmo com a ditadura militar, novos espaços políticos são criados principalmente por se restringir, controlar ou se extinguir os espaços anteriores do fazer política, mas que esses novos espaços têm uma nova conformação por comportar segmentos da Igreja, dos partidos de esquerda e trabalhadores das mais diversas categorias. Martins (1984), ao apreciar as Comunidades Eclesiais de Base, o faz não as caracterizando como espaços da política de classes, não no sentido clássico, mas como espaços em que, se a política de classes está presente, não é ela que dá o tom, o que une e unifica a todos é a questão da justiça, da pobreza e da cidadania. Para dar conta de toda a riqueza explicativa de Martins esse espaço seria insuficiente, assim, ao escolher o trecho abaixo, o faço certo de que restringi a sua explicitação da ação das Comunidades Eclesiais de Base e da sua importância no contexto das lutas políticas e sociais que emergem nos anos de 1980. Martins fala da categoria explicativa pobre, eleita pelas CEBs para dar conta de todas as categorias que lutam por seu espaço político de expressão:

Ao invés de cada um se ver no isolamento de vítima irremediável das condições sociais e históricas iníquas, ele se descobre como vítima coletiva da opressão e da injustiça. Penso que é muito importante considerar que a categoria 
explicativa que organiza o pensamento dos membros dessas comunidades é a categoria de pobre. Mas, certamente errará quem julgar que para o cristão da CEBs pobre é quem tem pouco dinheiro. Se assim fosse, essas comunidades não teriam nenhum papel relevante nestes anos todos. A categoria pobre é ampla e abrange todo tipo de pobreza - desde a miséria da fome até a falta de justiça e direitos, a desigualdade, a opressão, a falta de liberdade, o comprometimento da fé pela degradação do homem. É diferente da situação de classe social, que se define por uma categoria econômica, como o salário ou a propriedade, que por isso fica centrada na produção. A categoria pobre, ao contrário, tem uma definição ética e histórica que implica em considerar os resultados da produção, não só a acumulação do capital, mas também a acumulação da pobreza que dela resulta. A realidade social passa a ser considerada não a partir da igualdade jurídica que sustenta as ficções básicas sobre os direitos, mas a partir das desigualdades econômica e social, que desmarcara e denuncia a falta de direitos. É por isso também que é outra a concepção e a prática das relações sociais. Não a concepção societária, abstrata e ideológica das relações de conteúdo contratual, que pressupõe a equivalência, a igualdade, a negociação, do eu e do outro. Mas a concepção comunitária, concreta e utópica, democrática, do nós. É comum na linguagem desses movimentos, grupos e entidades a palavra união e na sua prática a busca das condições para unir os pobres - os famintos, os injustiçados, os marginalizados. (MARTINS, 1984, p. 106)

As observações de Martins revelam que a luta de classes não se restringe ao espaço ou determinações econômicas, mas vai além ao incorporar a cultura, a ética, a política, ao incluir excluídos, ao incorporar segmentos do campo, não apenas os assalariados, mas, inclusive, os pequenos produtores familiares. Assim, as Comunidades Eclesiais de Base são uma novidade política que faz aparecer outros sujeitos, sujeitos que ficavam encobertos pela dicotomia burgueses e proletários. Essa postura me faz levantar questões com relação a Crateús. Afinal, Crateús, no Ceará, talvez seja a única região diocesana que inovou as práticas religiosas a partir da criação das Comunidades Eclesiais de Base. Meu interesse se volta para Crateús por isso, por ser espaço de CEBs, por ser espaço de uma nova Igreja, de uma Igreja popular e libertadora.

Ao me voltar para Crateús, após ter estudado a Diocese do Crato e seu impacto, intencional ou não, sobre os trabalhadores do campo, na 
organização dos sindicatos dos trabalhadores rurais, aparecem as seguintes questões: a atuação daquela Diocese estava realmente em consonância com o Concílio Vaticano II? Qual a repercussão que a repressão usada pela ditadura militar teve sobre a Diocese de Crateús? Quais os elementos da sociedade que a apoiavam e como se configurava esse apoio?

Analiso a ação da Diocese de Crateús sob o comando de D. Fragoso a partir das circunstâncias políticas que à época de sua criação estiveram presentes. A Igreja mudava, procurava abrir espaços para os leigos e para uma reflexão teológica mais radical, como mudava a sociedade brasileira e latino-americana. Os caminhos da Igreja levavam a uma abertura em suas estruturas hierárquicas e autoritárias e a uma inserção social e política mais radical, mais voltada para a crítica ao capitalismo e a definição mais clara de seu espaço sócio-religioso, isso repercutia na ação sobre os pobres para a superação da pobreza. Até que ponto essas circunstâncias religiosas e políticas, que definiram posições na sociedade e no interior da lgreja, conformaram a ação da diocese? Qual a experiência vivida por D. Fragoso que o faz avançar na linha de uma Igreja pobre e voltada prioritariamente para os pobres?

D. Fragoso compreendia que esses grupos eram fundamentais para uma ação mais engajada da Igreja na sociedade. Ele próprio era oriundo da Ação Católica Especializada, inclusive havia sido coordenador da Ação Católica Operária -ACO- para todo o Nordeste. Suas posições mais avançadas, na linha de uma Igreja encarnada e comprometida, segundo alguns autores, eram decorrentes de sua relação com os movimentos leigos. Segundo ele próprio, sentia falta em Crateús da Ação Católica Especializada, de jovens que não tinham, em sua formação, o peso da Igreja Hierárquica.

Nas visitas, perguntei se tinham ação católica especializada. Nenhum dos padres tinha experiência alguma de ação católica especializada. Ora, eu vinha de dez anos de trabalho como assistente regional da Juventude Operária Católica (JOC) do Nordeste. Em S. Luís do Maranhão, durante seis anos, com a benção e aprovação do meu velho amigo, o arcebispo D. José de Medeiros Delgado, consegui lançar a 
JOC, a Ação Católica Operária (ACO) e a Juventude Agrária Católica (JAC). Vinha com o desejo de encontrar, na diocese nova, alguma coisa. (FRAGOSO. O Rosto de uma Igreja, Edições Loyola, S. Paulo. 1982 p. 20)

Mas havia um núcleo da Juventude Estudantil Católica - JEC em Crateús. Apesar de não ser comentado por D. Fragoso, havia $\mathrm{JEC}^{16}$ e outros movimentos de jovens que atuavam a partir da Igreja nos bairros populares de Crateús. Até que ponto esse passado poderia indicar uma tentativa de encarnar a Igreja Católica local? Até que ponto D. Fragoso já contava com uma base, mesmo que pequena, para sua pastoral em favor dos pobres? Porque ele, em seus escritos não se refere às mesmas?

Percebem-se os compromissos de D. Fragoso com os segmentos mais pobres e oprimidos da sociedade brasileira. Sua ação junto à ação católica especializada indica abertura para o mundo, para a história, compromisso com os segmentos mais pobres e explorados e com todos aqueles que comungam com os ideais de uma sociedade mais justa. Essa sua postura, alheia aos dogmatismos e compromissos político-ideológicos da Igreja hierárquica o aproxima das esquerdas marxistas, que se sentem à vontade com os padres e leigos da Diocese de Crateús. Da mesma maneira que atuavam, em consonância com a Diocese, os estudantes ligados à esquerda clandestina ${ }^{17}$ que participaram inclusive dos encontros diocesanos de 1970 e 1971, questionavam a ação da Diocese, exigiam radicalidade e solicitavam a inclusão de temas. O testemunho de Masters (1970), que participou do primeiro dos encontros, é revelador dessa convivência entre segmentos político-religiosos aparentemente tão díspares. É interessante frisar as

\footnotetext{
${ }^{16}$ A Juventude Estudantil Católica existia em Crateús desde o início dos anos sessenta do século XX . Seu coordenador era o Padre Irismar e contava com vários jovens inseridos em ações sociais na periferia da cidade.

${ }^{17}$ Nos textos escritos por C. Boff(1981) e Mesters (1970), há referências aos grupos de esquerda, inclusive da dificuldade que era incorporá-los as reuniões diocesanas em função das questões que traziam, questões que não eram ainda postas para as bases. É interessante lembrar que a ação da Igreja em Iporanga, em área que lhe pertencia, tinha à frente membro bastante conhecido do Partido Comunista do Brasil. Nessa área rural foi implantada uma experiência de Reforma Agrária que resultou em problemas ainda não resolvidos. O caderno 25 anos de Caminhada, $\mathrm{N}^{\circ} 16$, é um relato dessa experiência feito por este membro do PCdoB, coordenador do projeto a pedido de D. Fragoso, que usa pseudônimo e nomeia seu texto com o título de: São Loganso, alguns passos de uma trajetória. 1997.
} 
questões colocadas para discussão nesses encontros como se era perdoável matar numa situação de luta como a que enfrentavam. Questão que somente poderia ter sido levantada pela possibilidade da luta armada. Nesse sentido, coloca-se em questão a visão de D. Fragoso, não quero dizer que ele compartilhasse dessa visão da luta armada, mas ela não estava fora do foco em Crateús.

A presença dos segmentos de esquerda em Crateús é motivo de análises e reflexões por parte de visitantes como Boff (1989), Comblin (1989) e Mesters (1989), da mesma maneira que são colocadas por remanescentes do movimento de Igreja de Crateús. Inclusive, em determinado momento, em entrevista cedida a mim por Ivânia ${ }^{18}$, ela se refere a este momento inicial, até o início da década de 1970, como sendo um momento de maior intensidade política. A presença comunista indicaria formas de luta diferentes daquelas propostas pelas Comunidades: trabalho político que amadurece ao longo da caminhada nos diversos enfretamentos com as forças locais e regionais da ditadura.

É interessante frisar que após os anos iniciais da década de 1970 já não se fala mais nessas pessoas da esquerda clandestina. Todo esforço da Diocese de organização dos segmentos populares se faz através das Comunidades Eclesiais de Base. Essa perspectiva organizativa se apoiava nas comunidades, chamadas por D. Fragoso de comunidades sociológicas, com o termo eclesial passam a se distinguir das anteriores por focar sua ação na promoção integral do homem. O seu objetivo, ao contrário das comunidades dos anos de 1950, não era atingir patamares de desenvolvimento econômico e social que repercutissem no povo trabalhador. Seu objetivo era promover mudanças que implicassem na superação das desigualdades econômicas, sociais e políticas associadas à Mística da Fé Cristã encarnada na Justiça e na solidariedade entre pobres e oprimidos.

\footnotetext{
${ }^{18}$ Ivânia é membro da Fundação D. Fragoso, fundação com sede em Crateús, em entrevista cedida ao autor.
} 
Esse trabalho com comunidades, apesar de acontecer no local de residência e trabalho dos envolvidos, revelava suas implicações e repercussões nos âmbito da sociedade regional e nacional. Da mesma maneira não escondia as diferenças sociais e econômicas que existiam, mas procurava desvelar a raiz dessas diferenças para superá-las. Eram espaços de educação e conscientização, de organização e luta. $O$ eclesial era básico nesse processo de organização comunitária por mostrar que a religião cristã não partilhava com a opressão, mas era antes de tudo libertadora por pretender a salvação integral do homem, salvação que não era pretendida apenas na outra vida, não havia separação entre a vida terrena e a vida no paraíso, esta última era consequência da primeira.

Com as Comunidades Eclesiais de Base desaparece a visão idílica do capitalismo, como um modo de produção capaz de promover a felicidade e o bem estar a todos os segmentos da sociedade. Nessa visão, a pobreza aparecia como uma consequência da inatividade da sociedade, principalmente dos setores produtivos, que não planejavam sua ação econômica nem social, que agiam movidos pelo egoísmo que deveria ser extirpado. Mas, na medida em que as ações decorrentes do debate começavam a ser implementadas e as prioridades estabelecidas, ficavam evidentes as diferenças que existiam entre os segmentos da sociedade local: os empregos não eram capazes de atender as demandas, os salários não eram suficientes, a modernização rompia com as relações de trabalho pré-existentes e a expulsão da terra se tornou corriqueira com a modernização do campo.

Da mesma maneira não era colocada em questão a situação geopolítica e econômica das comunidades. Nem sempre essas comunidades podiam associar-se ao desenvolvimento na forma como ocorria nacionalmente, ficavam isoladas, não conseguiam articular-se com as áreas modernas concentradas nos grandes centros e nas suas redondezas. Eram ilhas que não repercutiam nas demais áreas a não ser quando produtoras das matérias-primas necessárias à grande indústria. $O$ planejamento nacional 
observava essa lógica perversa do capitalismo que exigia a monocultura, a mecanização, o financiamento em escala, ao pequeno produtor cabia assegurar terra para produzir alimentos numa lógica que não podia ser igual, se assim fosse, acabaria por condenar parte de seus familiares ao desemprego e à fome. Mas interessava ao capital enquanto produtor de braços para o trabalho temporário nas grandes fazendas a preços baixos, pois, como diz Martins, o processo de reprodução da mão-de-obra se dava nas áreas de produção familiar.

Em sua análise das migrações temporárias do homem do campo no Brasil ele diz:

(...) Do outro lado, a empresa capitalista, que, no campo ou na cidade, utiliza a força de trabalho do migrante temporário, não despende todo o capital necessário à sua reprodução como trabalhador para o capital. É verdade que o salário recria, no operário, o camponês; que por sua vez recria o operário. Mas, para o migrante, o salário apenas complementa a sua reprodução e a de sua família como força de trabalho. Porém, enquanto camponês, se recria como operário para o capital, inteiro, pronto para trabalhar. O capital não paga, assim, o preço de formação da mão-de-obra de que necessita. Quem paga esse preço é a família camponesa. E, com isso, o capital não expande o mercado interno de que necessita para se expandir. (MARTINS, 1986, p. 54)

Deixando essas observações de lado, pelo menos por enquanto, devo destacar que as comunidades, no seu novo formato de comunidades eclesiais, surgem a partir dessa cultura das comunidades, que remonta a Pe. Ibiapina. Isso porque o isolamento em que viviam as populações rurais é rompido, o sindicalismo rural e os direitos trabalhistas são introduzidos e a cultura da fala, da expressão de sua realidade, é estimulada. Da mesma maneira, claro que por outro viés, o processo de modernização, a expansão da monocultura e da bovinização acabam por gerar vilas rurais nos arredores nas fazendas, aproximando os agricultores camponeses e confrontando-os com uma questão que não era evidente: a questão da terra para trabalho. 
Quando a Igreja nesse debate que diz respeito ao desenvolvimento de comunidades, se depara com a realidade do campesinato e das populações periféricas das grandes cidades, acaba por rever sua posição, pelo menos parte dela muda sua percepção da realidade e, com ela, do seu papel como Igreja. A pobreza é uma realidade que apenas se reproduz no mundo capitalista e com isso, em consonância com sua ação desde o início dos anos de 1950, espaço para a pregação de outras doutrinas que a ameaçam, como o ateísmo comunista. A Igreja, assim, parte para outro tipo de ação: uma ação que visa a promoção do homem, e nisso não tem novidade com a percepção anterior, mas uma promoção do homem que supere os mecanismos de reprodução da pobreza.

Nesse momento, a Igreja já encontra os instrumentos de percepção da realidade, o próprio marxismo the permite enxergar o funcionamento do capitalismo, o marxismo que combatia lhes dá as armas necessárias para discutir a realidade e perceber as contradições do capitalismo. A pretensão da Igreja, como antes, era a promoção do homem, mas não se pode promover o homem sem romper com as amarras que os fazem presos à miséria e à opressão. Sua doutrina afirma que todos os homens são iguais e que todos devem ser igualmente beneficiados pelo desenvolvimento.

Estimulados pelo Concílio Vaticano II, algumas dioceses passam a atuar na linha da libertação, libertação que somente se consegue de maneira coletiva num processo educacional que permita, já que mediado pela realidade, descobrir as razões da pobreza e da opressão. A instalação da ditadura militar em 1964 foi um marco desse novo tipo de ação por deixar claro que as mudanças propostas nos anos anteriores: reforma agrária, direitos trabalhistas, liberdade de expressão, dentre outros, não eram objetivos desejados pelos segmentos dominantes. Para estes, a exploração do trabalho pelo capital, a submissão política e social do trabalhador, era uma necessidade no processo de reprodução do capital. As perseguições a líderes políticos e sindicais que defendiam reformas mais profundas em consonância com as necessidades populares se tornaram frequentes e, 
membros da Igreja, religiosos e leigos, passaram a ser perseguidos por pleitearem mudanças que beneficiassem os trabalhadores. Nesse aspecto, a história da Diocese de Crateús está repleta de exemplos, padres foram mantidos presos, outros foram expulsos, lideranças sindicais ligadas à Igreja foram investigadas e retidas.

A Diocese de Crateús foi criada em 1964, seu primeiro bispo, foi D. Fragoso. $\mathrm{Na}$ sua posse na diocese, em discurso feito em praça pública, na recepção que thes deram as autoridades locais e estaduais, critica a maneira de fazer Igreja do bispo de Sobral, D. José Tupinambá da Frota assentada no desenvolvimentismo da Igreja dos anos de 1950. Deixa claro que sua ação pastoral estará voltada para os pobres, para a justiça, contra a opressão e a favor da organização política dos camponeses.

Da mesma maneira que não encontrou uma Diocese sem história, em Crateús já havia indícios de uma ação da paróquia local junto aos bairros populares, D. Fragoso vinha de uma experiência exitosa quando em S. Luiz do Maranhão, como bispo auxiliar, coordenava a ACO. Sua percepção de Igreja estava marcada por esse trabalho e pelo Concílio Vaticano II.

D. Fragoso estava, portanto, marcado por uma Igreja reformada e inserida no meio do povo, mas sua vontade de construir uma Igreja Nova, assentada nos princípios emanados pelo Vaticano II, não seria implementado se naquela cidade não houvesse uma base sobre a qual pudesse assentar seu trabalho. A adesão que seu projeto de Igreja obteve, significa que já existiam reflexões sobre a pobreza e sobre a exploração a que estavam submetidos os trabalhadores do campo, sobre a opressão e a inexistência de justiça social. Naquela Diocese já existiam padres e religiosos preocupados com as desigualdades sociais e leigos capazes de associar-se ao bispo nessa ação pastoral.

D. Fragoso não chega e se acomoda às ações paroquiais então em desenvolvimento. Ele tinha uma visão de Igreja e a partir dela uma 
pretensão: fazer uma igreja consonante o Concílio Vaticano II, voltada para a promoção do homem integral. Eram dez paróquias que constituíam a Diocese, oito oriundas da diocese de Sobral e duas recebidas da diocese de Iguatu. Ele visita cada uma e começa por conversar com os padres e religiosos, realiza as semanas catequéticas que na sua avaliação são fundamentais, agregando nesse trabalho os leigos, principalmente aqueles que já eram responsáveis pela catequese das crianças e dos adultos. A partir daí planeja suas atividades, com a presença de todos: religiosos e leigos. Ganha a confiança de muitos, demarca espaço, estabelece a presença do leigo numa Igreja que o tinha apenas suplementarmente.

Não era somente ele que chegava que tinha uma visão de Igreja renovada pelas discussões e decisões assumidas pelos bispos no Concílio Vaticano II. A nova visão da Igreja também repercute sobre muitos padres e leigos, principalmente naqueles que, como D. Fragoso, participavam das atividades educativas e políticas da Ação Católica Especializada. Padre Irismar era um deles. Portanto, para conhecer a Igreja de Crateús e a ação pastoral de D. Fragoso nesta mesma cidade, é importante refletir sobre a ação do padre Irismar, que já vivia em Crateús, e a ação dos jovens por ele acompanhados. Por isso, causa estranheza o silêncio que se faz em torno de sua prática pastoral e dos jovens que o acompanharam no desenvolvimento dessa ação mais social e mais condizente com os novos princípios que orientavam a Igreja Católica após o Vaticano II. Também, não se pode ignorar a influência de jovens estudantes da região de Crateús, que residiam e estudavam em Fortaleza, ou em outras capitais, onde eram intensas as atividades das agremiações políticas como a União dos Estudantes.

A Cáritas Diocesana foi um dos primeiros movimentos criados por D. Fragoso ao chegar em Crateús, em 1964. Contudo, antes mesmo de sua chegada, os alimentos americanos da 'Aliança para o Progresso' já chegavam a Crateús através da Diocese de Sobral. Excetuando o trabalho das 'Luízas de Marillac' nos bairros, que procurava dar uma outra conotação ao uso dos alimentos, o restante era simples distribuição de 
alimentos de forma assistencialista. (Caderno da Diocese de Crateús, № 14 . Sem referência aos autores, p. 9) ${ }^{19}$

Além dessa referência inicial a esse grupo de jovens chamadas de Marillac, a autora, cita a Casa da Juventude Betânia, a Sociedade dos Habitantes dos Bairros, alusão às sociedades de bairro que existiam em Crateús, as Sociedades Habitacionais, centradas, segundo ela, nos mutirões habitacionais, a Frente Social Cristã e a Juventude Estudantil Católica - JEC. São referências importantes que indicam haver uma base sobre a qual se poderia assentar toda a ação posterior da Igreja Libertadora de D. Fragoso. Mas essa não é a única relevância desse caderno, a citação acima foi mantida na íntegra por situar a distribuição de alimentos oriundos de doações norte-americanas dentro de uma perspectiva crítica. Aliás, na leitura desse caderno estão presentes algumas mágoas, já que ele foi escrito, pelo que entendi, por pessoas que dirigiram a Cáritas Diocesana de Crateús ${ }^{20}$.

Todas essas questões têm como foco a questão maior de que a história não se faz sobre vazios políticos e que, se ao mesmo tempo é ruptura, é também continuidade. Essa reflexão me leva, necessariamente, ao meu objeto que é se a ação de $\mathrm{D}$. Fragoso, a ação política e não só ela, mas, também, a ação religiosa, sedimentou uma cultura política crítica que embasa a luta dos trabalhadores da região fazendo-os elementos fundamentais de conscientização e luta no processo de construção da classe trabalhadora.

Na sua ação pastoral, D. Fragoso procurou a ajuda de padres, religiosos e leigos de outros países. Segundo os autores ${ }^{21}$ que fizeram, a seu pedido, a

\footnotetext{
${ }^{19}$ No caderno de número 14 , não há nenhuma referência a autor ou autores, no entanto, na página 8 deste caderno há um trecho que começa assim: "Eu, Leinad, tenho a consciência dos meus valores, mas sobretudo tenho a consciência dos meus limites." Que era alguém do sexo feminino a continuação do trecho em apreço confirma assim:"Saída do movimento estudantil ...." p. 8

20 "Fomos convidados por D. Fragoso para fazer um registro da experiência do Projeto Cáritas em Crateús. Alguns colegas recusaram-se. Com certeza, eles tiveram boas razões para isso. Outros, no entanto, pensaram ... por que sim? Por que não? ... e toparam. E aqui vai a tentativa! Até porque não é fácil escrever sobre isso ... Cáritas é careta! ... é leite em pó!... é, também, imperialismo!” (Caderno Fazendo a nossa História. 25 anos de caminhada. Diocese de Crateús, CAD. n 14, 1997)

${ }^{21}$ D. Fragoso tinha uma preocupação muito grande com a memória, afinal era fundamental que as ações pastorais fossem revistas, refletidas, discutidas, analisadas e lembradas sempre. Para ele a
} 
reconstituição e análise crítica de sua ação diocesana em Crateús, sem a ajuda externa ${ }^{22}$ teria sido quase impossível a atuação de uma Igreja reformada nessa Diocese. Com isso estariam diminuindo a base local? Não sei, alguns desses autores fazem questão de enfatizar a base local, talvez, e esta é outra questão, pela ênfase que se dá aos estrangeiros, mas com certeza, para D. Fragoso, que contava com número bastante reduzido de religiosos a serviço da Diocese, a presença de estrangeiros foi fundamental.

Nas entrevistas que realizei, um dos padres com quem falei chamou a atenção para outra leitura. Para ele, D. Fragoso teria se mostrado um grande político ao atrair os religiosos estrangeiros. Ainda segundo o entrevistado ${ }^{23}$, os contatos que fez ao longo de sua temporada em Roma, durante o Concílio Vaticano II, serviram para articular apoios a sua ação e ao mesmo tempo blindá-la contra a igreja nacional e contra a ditadura militar, qualquer ação coercitiva logo se tornaria conhecida e ações de defesa poderiam ser tomadas. Essa avaliação que aponta a necessidade de divulgação da ação repressora do Estado como uma forma de defesa daqueles que lutaram pelos direitos humanos durante os governos militares é também realizada por Maria Helena Moreira Alves (1989), quando aprecia a ação de D. Evaristo Arns nos anos setenta e oitenta do século passado. Para ela, a igreja articula com sua força uma rede de defesa dos perseguidos políticos quando usa sua força enquanto instituição internacional com amplas ramificações. Associa-se, também, a esse mesmo tema, Ana Maria Doimo (1995) quando afirma que os novos movimentos sociais somente puderam existir dado o aparato da Igreja Católica, como um todo.

memória ajuda as novas gerações a compreenderem a história e assim agir para sua continuação e consolidação. Nesse sentido ele estimula aos que participaram de sua ação pastoral a escreverem os cadernos Fazendo nossa História, assim vamos encontar cadernos escritos por Mesters, Comblin, Boff, Eliésio, Siebra, Maurizio, Leinad, Verdésio, Françuita, e tantos outros, religiosos, leigos, militantes de CEBs, sindicalistas, etc.

${ }^{22}$ Padre Eliésio dos Santos, em entrevista a este autor, afirma que: "sem a articulação externa, com as Igrejas de outros países, não teria sido possível o trabalho pastoral de Crateús, a repressão teria sido maior do que realmente foi."

${ }^{23}$ Padre Eliésio dos Santos, vigário de Ipueiras. 


\subsection{Igreja, CEBs e Sindicatos dos Trabalhadores do Campo}

O início da ação de D. Fragoso até mais ou menos o começo da década de 1970 é visto por alguns dos entrevistados, principalmente alguns leigos, como é o caso de Ivânia, como um momento de maior intensidade, isto porque a presença dos movimentos era maior. Segundo texto de Padre Eliésio (1989), esse era o momento de presenças significativas como fora o caso do Movimento de Educação de Base, da Cáritas, do movimento de organização dos sindicatos dos trabalhadores rurais.

Os objetivos propostos para esse primeiro momento da ação diocesana de D. Fragoso mostravam sua preocupação com a organização das comunidades. Para tanto, usou a Cáritas, a distribuição das doações oriundas dos Estados Unidos serviam para atrair a população e começar a discutir a necessidade de organização comunitária.

Essa forma inicial para agregar as populações, a partir das doações, foi depois criticada pelo próprio D. Fragoso (1982). Para ele, eram esmolas que serviam mais aos interesses norte-americanos do que aos pobres. Segundo ainda sua opinião, qualquer tipo de organização com base em "esmolas" estava fadada ao insucesso, no momento que elas cessassem os comunitários beneficiados por elas desapareceriam. Era necessário que a manutenção da organização comunitária tivesse como base os próprios recursos dos participantes.

Mas, verifica D. Fragoso, "que muitos não se ligavam diretamente à ação comunitária por um compromisso, por uma descoberta do valor da vida comunitária. A atração dos gêneros era mais forte. Quando estes faltaram, muitos se foram e houve uma crise das comunidades." (FRAGOSO, 1982, p. 25).

Em determinado momento, ele fala das comunidades chamadas por ele de sociológicas que seriam agrupamentos onde havia interação entre as 
pessoas sem que houvesse laços mais afetivos. Acredito que esta é uma questão importante para a análise de Crateús e das Comunidades Eclesiais: estas ao mesmo tempo que são políticas, são também comunidades afetivas, afinal o eclesial remete aos irmãos em Cristo. No meu entendimento, o processo de aglomeração das populações rurais era ainda recente, pois era recente o processo de expulsão das populações rurais, principalmente dos moradores. Desse modo, não haviam se firmado laços de amizade e de cooperação capazes de superar as distâncias a que estavam acostumados quando residiam nas grandes propriedades.

Reunidas as comunidades, confrontadas com as suas realidades, caberia às pessoas que as integravam, perceber essas realidades dentro do contexto maior, não apenas o contexto religioso, mas também o meio social e econômico do qual eram parte submetida e empobrecida. Assim, recorrem o bispo e seus agentes, religiosos ou leigos, ao Movimento de Educação de Base, para promover a educação, ensinar a ler e escrever, mas não da forma convencional. O MEB usava o método de Freire em que o ponto central estava centrado no aprender a ler, lendo a realidade envolvente de maneira crítica e dialogada. Conscientizar para libertar; esse era o foco, como também, no processo de educação formar grupos, que seriam a base das Comunidades Eclesiais, habituados à leitura da realidade a partir do diálogo com o outro. Mas, D. Fragoso também rompe com o MEB, sua justificativa é o excesso de centralização que impedia a autonomia das dioceses. $O$ MEB era ligado hierarquicamente à CNBB e financiado pelo governo federal, portanto sujeita a injunções da Igreja e do Estado.

O motivo mais imediato, no entanto, teria sido a demissão sumária da assistente social italiana Maria Teresa Nodari, como ele mesmo diz:

Um dia, fomos também forçados a fechar o MEB. Entre as sete pessoas permanentes do sistema local, tínhamos uma assistente social italiana, chamada Maria Teresa Nordari. Recebemos, do arcebispo-presidente do conselho diretor nacional do MEB, um telegrama que comunicava a demissão sumária de Maria Teresa. O bispo local, presidente do sistema diocesano por força do estatuto, não fora consultado. Maria 
Teresa, pessoa idônea, adulta e responsável, também não fora consultada. (FRAGOSO, 1982, p. 27)

A organização dos sindicatos, no começo orientada pela freira francesa Paulette, objetivava a organização dos trabalhadores por direitos trabalhistas, terra e melhoria nas relações entre proprietários e camponeses. Nesse caso, D. Fragoso, através da ação da irmã Paulette, procurava informar aos trabalhadores dos seus direitos, principalmente do direito a organização autônoma da classe, da legislação sindical e das leis de proteção ao trabalhador rural, para que, assim, pudessem assumir com independência, inclusive da Diocese, a direção dos sindicatos. Diferente da maneira como a Diocese do Crato atuava no meio sindical, procurando manter o controle dos trabalhadores e de suas lutas, foi necessário que os próprios trabalhadores, com prejuízo para as duas partes, tomassem a iniciativa de romper com essas amarras. Até que ponto essa autonomia foi promovida, coube a pesquisa mostrar, pois em entrevista com ex-dirigentes sindicais, ficou claro o interesse da Diocese e das CEBs, e esse é um ponto a destacar, em ter pessoas ligadas a ela na direção do Sindicato dos Trabalhadores Rurais de Crateús.

Nesse ponto levantei as seguintes questões: Por que esse interesse pela direção do sindicato de Crateús? O que ele revelava, já que entre os sindicalistas escutados havia a acusação de pelegos para aqueles que se situavam fora da esfera da Diocese e das Comunidades? Estas eram constituídas em sua maioria de camponeses, portanto, base do sindicato e, pelos diversos depoimentos prestados a esse autor, como também pelas diversas análises dos autores que consultei tais como Martins (1984), Doimo (1995), Sader (1995), Wanderley (2007) e outros, as CEBs são organismos da sociedade civil, espaços de discussão sobre a realidade sociopolítica do país, conscientizadoras e libertadoras, estimuladas e apoiadas pela igreja, mas autônomas nas suas decisões e lutas.

Mesmo nos questionamentos que fazem em direção à Igreja, mesmo quando consideradas Igreja, sua ação decorre das pessoas que nelas estão 
envolvidas, leigos, cidadãos, críticos, pois é a crítica que as alimentam, portanto, pode-se dizer, ainda discutirei essa questão ao longo do trabalho, que são pessoas inteiramente aptas a criticar e concorrer à direção dos sindicatos. Estes são instrumentos de luta dos trabalhadores, institucionais, legais, mesmo durante a ditadura permaneceram existindo, com limitações, mas não deixavam de ser referência, dos quais as CEBs, por suas características nuclear e local, necessitavam para repercutir suas lutas na sociedade e incorporar as lutas sindicais mais amplas ao dia-a-dia das Comunidades Eclesiais de Base.

Mas, até que ponto, entre a proposta e a realidade, entre o desejo e a efetivação do mesmo, as CEBs se mantêm independentes das dioceses e dos agentes religiosos e leigos ligados à lgreja? Martins, nos seus escritos de 1994, 2000 e de 2003, diferentemente das suas análises anteriores ${ }^{24}$, começa e avança numa crítica à Igreja, às CEBs, à Pastoral da Terra e ao MST que estariam impondo interpretações e visões sobre o rural a partir de concepções políticas atrasadas, equivocadas e autoritárias. Não chego a concordar com ele, pois sua premissa é que impediram a realização de políticas agrárias favoráveis à pequena produção rural por politizarem e partidarizarem o debate. De qualquer maneira, a presença da Igreja nas comunidades eclesiais através de seus agentes, culturalmente mais aptos para o discurso, ao mesmo tempo, que representam a lgreja, o que pesa muito na hora dos debates e da tomada de decisões, são também agentes políticos, não poderiam deixar de sê-los.

Essa é uma reflexão que será feita mais adiante quando analisarei o papel de D. Fragoso a partir das suas afirmativas de que a luta dos trabalhadores deve ser feita pelos próprios trabalhadores, cabendo à Igreja ação mais supletiva, de apoio, quando necessário.

\footnotetext{
${ }^{24}$ Lembro texto citado anteriormente neste trabalho onde Martins comemora as CEBs como um instrumento de luta que extrapola as limitações sindicais e partidárias. O Texto a que me refiro é: Os novos sujeitos das lutas sociais, dos direitos e da política no Brasil rural. In A Militarização da Questão Agrária no Brasil. Martins, José de Souza. Vozes, 1984, p. 75.
} 
No entanto, alguns autores, dentre eles destaco C. Boff (1981) apontam a necessidade da presença da Cáritas, mesmo que sua finalidade seja, como diz Fragoso, escoar o excedente da produção de grãos dos Estados Unidos com a finalidade de manter vendas e a lucratividade do campo norteamericano. Para eles, a origem do dinheiro e dos grãos é questionável, mas se poderia fazer o trabalho de organização a partir das doações norteamericanas alertando ou esclarecendo a origem e os motivos das mesmas. Seria também um instrumento de conscientização e seria uma ajuda fundamental na organização das populações rurais tão carentes.

Essa posição de D. Fragoso aparece como um elemento, que se não dificultava o processo de realização de uma ação conscientizadora e libertadora, gerava dificuldade dada à imensa pobreza das populações abrangidas pela Diocese. Questões como essa, somadas à forma própria de atuação de D. Fragoso, indicam-me uma personalidade forte e marcante que ao deixar a Diocese, deixou-a órfã. Compreendo que, esclarecerei melhor depois, o refluxo que sofre a ação da Igreja e das CEBs em Crateús, tem muito a ver com a saída de D. Fragoso, mesmo que ele não fosse centralizador, mesmo que ele tenha agido, na grande maioria das vezes, de forma democrática e sustentado a posição que emergia das bases. Como acentuam vários autores e entrevistados, D. Fragoso era um homem de posições fortes, destemidas, que se avantajava também por ser bispo da Igreja católica. Era um homem difícil de ser substituído e que passava força e coragem às bases, ao mesmo tempo em que provocava medo aos opositores. Mesmo que tenha sido perseguido pelas forças de segurança nacional, prendê-lo ou retirá-lo de Crateús, no caso de uma ação da lgreja, poderia causar repercussões difíceis de serem contidas e não apenas no nível local, mas nacional e internacionalmente.

Desde o início ficou claro que a ação de D. Fragoso não era apenas política, mas também religiosa. Sendo assim não poderiam ter um caráter apenas de movimento, de conjuntos que se formavam na luta e para a luta, nessa a 
derrota significaria refazer todo o percurso ${ }^{25}$. As comunidades eram vistas por parte do clero como igrejas vivas, de reforma da própria Igreja. Sua tentativa era sedimentar uma visão de igreja e sociedade que não permitisse recuo, que implicasse em andar sempre para frente no sentido da realização do homem em patamares sempre mais amplos. Com as Comunidades, o trabalho de conscientização alcançaria a grande maioria dos fiéis, portanto homens e mulheres que se tornariam, usando uma linguagem de Freire, cuja pedagogia foi amplamente utilizada em Crateús, cada vez mais homens e mulheres conscientes de sua importância e de sua humanidade.

Se tomarmos, como tomamos no decorrer do trabalho, a visão da história de D. Fragoso, verificaremos que ele via a história como processo de realização do homem, da ação do homem no processo de autoconstrução, ou ontocriativo como o quer Kosik (1976), cria o mundo e a si mesmo a partir de sua práxis. Ele via que esse processo era um processo de luta, luta de classes e ele em várias ocasiões se refere à classe social, mas de uma luta que não eliminava o opositor, como Freire, esse processo para ele era um processo de libertação também do opressor. Mas sua visão da história não era carregada pela luta, ou o grande confronto capaz de, a partir da direção segura da vanguarda, provocar a ruptura, gerando imediatamente o socialismo ou a ditadura do proletariado. Para ele, a história se faz ao longo das lutas cotidianas e aparentemente miúdas do dia-a-dia: luta pela terra, por justiça, luta pela representação profissional, luta pelo reconhecimento de direitos. Sua visão de história se aproxima daquela apresentada por Thompson (1987) que acentua as lutas cotidianas e permanentes das pessoas comuns, inicialmente sem coordenação nem direção, mas que no momento de sua emersão, vão possibilitando consciência e organização, como responsáveis pela superação de uma etapa histórica por outra. ${ }^{26}$

\footnotetext{
${ }^{25}$ Principalmente Ivânia, coordenadora da Fundação D. Fragoso, que nomeava a ação do MEB, da Caritas, do Sindicato, e acredito, principalmente pela conotação que teve ao ter à sua frente um membro do Partido Comunista do Brasil, a experiência de Reforma Agrária em Iporanga, como movimentos. Acredito que os mesmos levavam a manifestações amplas, não significavam trabalho de base, local e aparentemente restrito.

${ }^{26}$ São essas lutas, são as diversas formas de organização que vão se estruturando que permitem a percepção da classe. Thompson, assim se refere: "Por classe entendo um fenômeno histórico, que unifica uma série de acontecimentos díspares e aparentemente desconectados, tanto na matéria prima
} 
Por isso, acredito que o caminho das Comunidades Eclesiais tenha se tornado o caminho seguido por D. Fragoso. As comunidades são pequenos agregados humanos que se caracterizam por viverem próximos e conviverem com os mesmos problemas. Pessoas que se conhecem e que se sentem à vontade umas com as outras, pessoas que, por sua proximidade, são capazes de falar, expor e expor-se sem receios, que se fortalecem no conhecimento e na amizade, que são capazes de falar de suas dificuldades e agruras, de sua realidade. Como, no entanto, a consciência de pertencimento a uma comunidade, de se enxergarem como iguais e vivenciarem as mesmas contradições não surgem de imediato, aparecem conflitos, resistências, barreiras à inserção mais ampla das Comunidades Eclesiais nas comunidades sociológicas. Mas, mesmo no interior das Comunidades Eclesiais aparecem conflitos, existem dificuldades em construir uma visão de conjunto, mais profunda das causas de suas agruras, ultrapassando a relação com o proprietário de terra seu vizinho, para enxergar no desenvolvimento do modo de produção capitalista a razão de sua pobreza. A Igreja serve para fazer essa mediação entre o local e o regional ou nacional, e a faz a partir do método pedagógico de Freire.

Mesters (1971) chama a atenção para os diversos segmentos existentes no $1^{\circ}$ Encontro de Pastoral da Diocese de Crateús, acontecido em 1970 que revelam a presença de pessoas diversas, com leituras diversas e diversos graus de compreensão da realidade. Eram os agentes, que tinham outras vivências, grau de escolaridade maior, maior nível de compreensão da realidade, eram os padres, as freiras, os membros da esquerda revolucionária, eram os observadores. Para ele, isso era um complicador por inibir a fala das bases e por colocar questões que não estavam no horizonte de compreensão dos homens e mulheres do campo. A linguagem falada, as articulações durante os encontros, a necessidade de marcar posição, segundo ele, confundiam as bases e, suas falas, se tornavam

da experiência como na consciência. Ressalto que é um fenômeno histórico. Não vejo a classe como uma estrutura, nem mesmo como uma categoria, mas como algo que ocorre efetivamente (e cuja ocorrência pode ser demonstrada) nas relações humanas." (Thompson. A Formação da Classe Operária Inglesa. Paz e Terra, 1987, p. 9) 
incompreensíveis para elas. Mas será que essas diferenças precisam ser analisadas como elemento negativo no processo de organização das bases, ou poderia ser visto de maneira positiva na medida em que acrescentava, na medida em que colocava em presença percepções diferentes, que forçava o olhar por outro viés que não o comum? Para Mesters, poderia resultar na perda de interesse dos comunitários com as reuniões promovidas pela Diocese. Da mesma maneira, as resoluções tomadas poderiam não refletir as necessidades dos trabalhadores de Crateús. Mas é bom frisar, e isso o farei, que a fala dos demais focam e informam, coloca em pauta o que era ignorado.

Esse acento nas diferenças internas chamou a atenção de Comblin (1971) e de Boff $(1981)^{27}$, para eles a linguagem deveria observar a realidade do povo e está atenta às necessidades das comunidades. Da mesma maneira que chamam a atenção para as diferenças entre os agentes de pastoral e a base, não sendo assim, não havia democracia e não havia a real expressão dos trabalhadores, as comunidades se assim continuassem estavam fadadas ao insucesso. Será que essa distância era acentuada em função da urgência dos agentes em transformar a realidade, da impaciência que o ritmo do povo provocava ou era apenas uma consequência do nível educacional desses agentes? Mas, os autores dos cadernos sobre os vinte e cinco anos da Diocese de Crateús, levantam uma suspeita que me parece mais séria: os agentes pouco sabiam da cultura popular, do modo de vida e das relações que mantinham com as diversas instituições da sociedade abrangente. Desconheciam o povo e suas necessidades e transferiam para eles seus próprios sonhos e frustrações.

A utilização do método de alfabetização de adultos de Paulo Freire, nesse momento, foi fundamental, mas sua pedagogia implica em compromisso com os pobres antes do compromisso com ideologias. Necessário que aluno

\footnotetext{
${ }^{27}$ Os autores acima referidos escrevem textos diferentes em um mesmo caderno. No entanto, as datas dos dois textos são diferentes, um é de 1971 e o outro de 1981, o caderno data do ano de 1989. Mantenho as datas dos textos porque mostram reflexões diferentes, não opostas, diferentes por serem expressão de contextos diversos, distantes dez anos.
} 
e professor, em sua prática pedagógica, apaguem seus preconceitos e se coloquem abertos para a apreensão do seu entorno, em diálogo, já que educação é um processo que somente se realiza em companhia, coletivamente. É na percepção da realidade, no descobrimento de suas contradições que o homem se percebe como sujeito e como pessoa, sujeito que transforma e é transformado por sua ação, para tanto é necessário que o mediador, aquele que se coloca como educador, confronte o homem com sua realidade para que nasça o homem que conhece, mas conhece transformando, agindo sobre o real e sobre os outros homens que com ele compartilham do real envolvente. Viver o real e viver o real coletivamente a partir da visão dos demais que é mediada por cada um. Viver é compartilhar e transformar para se transformar em ser vivente e histórico.

Se, como diziam Mesters e C. Boff, havia distância entre as falas dos diversos componentes da Diocese de Crateús (padres, agentes, coordenadores) e os membros das comunidades de base, que acabava por criar barreiras e dificuldades na relação entre essas pessoas comprometendo o caminhar das CEBs, a pedagogia de Paulo Freire senão acaba com as distâncias, permite, pelo menos, que as diferenças possam ser usadas para ampliar as percepções de realidade. Os agentes com seu conhecimento e suas falas podem indicar as contradições, podem conduzir uma reflexão, podem organizar o conhecimento, podem ajudar na abertura dos caminhos a percorrer. Sem as amarras das ideologias, o saber dos agentes foi fundamental para o aumento das CEBs e para a atuação política das mesmas.

Os números apresentados pela pesquisa realizada em Crateús com a coordenação do ISER indicam que em 1988/1989 havia na Diocese de Crateús 593 Comunidades Eclesiais de Base espalhadas nas dez cidades que compunham a Diocese. $O$ total de pessoas que participava das comunidades era de 30.359 participantes, a maioria era constituída de adultos, mas a presença de jovens e crianças era significativa, 4.958 e 7.847, respectivamente, o que poderia significar a continuação das 
Comunidades no tempo e nas lutas. Apesar das linguagens diferentes, apesar de professarem ideologias às vezes conflitantes, apesar dos perigos para os quais Mesters alertava em 1971, as Comunidades de Base cresceram e suas lutas foram importantes para a região de Crateús. Basta ver as lutas encetadas, lutas que reivindicavam bens e equipamentos coletivos (escolas, estradas, açudes, barragens, creches, coleta de lixo, energia elétrica, postos de saúde etc.), salários e condições de trabalho, moradia, condições de plantio, dentre outros.

Totalizaram, no período, 468 lutas reivindicativas. 241 delas estavam voltadas para a obtenção de equipamentos coletivos, 168 reivindicavam salários e condições de trabalho, 22 exigiam moradia e 18 condições de plantio. Não consta o número de pessoas envolvidas em cada uma dessas reivindicações, mas podemos ver que as mesmas estavam mais preocupadas com as carências coletivas do que pessoais, ou com os pleitos que abrangiam maior número de pessoas e significavam melhorias para as áreas em que residiam. O que se observa é uma população mais reivindicativa, mais presente como coletivo, mais politizada (o coletivo se sobrepondo ao privado).

Arendt pode nos ajudar a compreender as CEBs na medida em que elas são coletivas que geram espaços para a fala dos homens, espaços políticos, porque espaços de diálogo, da contraposição de opiniões decorrentes de vidas diferentes, autônomas, capazes de expressar-se em busca de uma unidade que não anule a diferença, mas compartilhe os sonhos na construção de uma nova realidade. Para Arendt, os espaços públicos da fala ou das falas são fundamentais no processo de construção do homem e de sua humanidade, momento em que se afirma sempre como mais humano, mais capaz de exercer sua capacidade de escolha e de compartilhar sua vida, independente, autônoma e diferente com todos os outros também dotados dessas mesmas prerrogativas. Negar essa possibilidade é para ela negar o próprio homem e sua humanidade. 
D. Fragoso, ao assumir um modelo diferente de Igreja, sabia que iria encontrar dificuldades. Não eram dificuldades oriundas apenas dos segmentos dominantes acostumada a ter a Igreja a seu serviço, os problemas também viriam dos chamados segmentos populares. Ele reconhece a resistência do povo à nova forma de ser Igreja, ao afirmar:

Com humildade e tristeza, verificamos que estamos sendo constantemente recuperados pela longuíssima tradição do autoritarismo central. Não somente o bispo e os padres, mas os leigos animadores, os líderes, os dirigentes de comunidades, são tentados, permanentemente, a viver o modelo que está na sua memória secular.

Este novo projeto de Igreja que estamos tentando viver em Crateús exige pelo menos quatro ou cinco décadas para se tornar modelo estável. Parece-me que, segundo a psicologia popular, as massas vivem da longa memória adquirida, isto é, da memória de seus avós, bisavós, antepassados e da experiência que viram ou que os outros lhes transmitiram. Quando agem, discutem, conversam, refletem, estão sempre enraizados nos modelos tradicionais em sua memória. $O$ modelo Povo Co-Responsável está começando. Não tem senão um pouco mais de uma década. Não é ainda referência em sua memória. (D. FRAGOSO. O Rosto de uma Igreja. Edições Loyola, 1982, p. 58)

Coblin (1971) reconhece a persistência da Igreja Conservadora. Para ele, essa Igreja não precisa sair de seu repouso, "[...] A sua vantagem é que resistem melhor ao desgaste do tempo. Os intelectuais e os jovens perseveram pouco, cansam-se depressa. Os conservadores nada fazem, não se cansam e ficam, recolhendo o prato depois da saída dos outros."

Mas, a figura do Bispo tinha um peso e ele sabia disso. Se ele queria uma Igreja nova, assentada no Povo de Deus, ele teria que ser firme, e é isso que faz desde o começo, o discurso de chegada já citado, confirma. Estaria esse ato inaugural de afirmação e de independência ${ }^{28}$ de D. Fragoso, ligado à cultura popular, tão afirmativamente como a coragem e a disposição dos senhores da terra sob os quais se achegam para obter proteção contra os demais latifundiários? Seria assim um traço da cultura popular que se revela

\footnotetext{
${ }^{28}$ Sobre esse momento que chamo de afirmação de uma posição, contrária a posição até então assumida pela Igreja Católica de Crateús, ver Luiz Gonzaga Gonçalves em seu artigo "Conflitos com a Cultura e Tradições locais", in Igreja de Crateús (1964 - 1998). Edições Loyola, 2005, p. 75.
} 
na adesão a esse senhor sem medo dos poderosos? Seria mais poderoso que os demais? Afinal era um bispo da Igreja Católica.

Para D. Fragoso, ao que me parece, o momento de afirmação não era mais do que o momento de expressão de uma visão de Igreja mais condizente com a Palavra Revelada, era expressão de uma nova Igreja, pobre com os pobres, mas capaz de superar a pobreza e as causas da mesma. Para ele, era um momento de construção de uma nova Igreja e de uma nova sociedade, construção que deveria ser implementada pelos pobres, a partir de sua ação, ação que nunca pensou distante da ação dos demais segmentos da sociedade, mas de uma ação que se queria conjunta, transformadora e humanizadora.

Mas, essa ação que pretendia conjunta, pelo menos no que diz respeito à Igreja, ele não articula com as demais dioceses do Ceará ${ }^{29}$, pelo menos não há nos escritos sobre Crateús qualquer referência a articulações com as dioceses cearenses, nem mesmo com as bases das demais dioceses. Não sei se aqui ele não se encontrava suficientemente seguro para ingerir nas bases das demais dioceses, ou para ser o estímulo à mudança dos demais bispos $^{30}$.

É interessante a leitura de Comblin (1971), Mesters (1971) e Boff (1981). São reflexões que tomam como ponto de partida a ação pastoral de D. Fragoso, mas contextualizada. Suas análises olham para a Igreja como um todo, a Igreja da Libertação e a Igreja Conservadora, mas uma Igreja que não nega o passado e, se ao mesmo tempo, se renova abrindo para uma presença mais constante e militante do leigo, se reconhece devedora da Igreja Conservadora, segundo eles, de um capital religioso construído ao

\footnotetext{
29 “A situação atual da Diocese explica-se pelas posições proféticas assumidas coletivamente ou assumida por diversos movimentos, ou assumida em nome da Diocese pelo bispo diocesano. Em relação as demais dioceses do Brasil, a Diocese de Crateús aparece relativamente isolada numa posição de 'ponta profética'. Essa posição e esse isolamento tornaram inevitável uma situação de repressão que já começou a se manifestar."

${ }^{30}$ Padre Maurizio, em entrevista cedida ao autor, faz referências a presença de pessoas de outras dioceses nos encontros de CEBs em Crateús. Da mesma maneira consta a presença de pessoas de outras dioceses nos relatórios dos encontros diocesanos de CEBs em Crateús.
} 
longo do tempo e que gerou a confiança necessária para a ação libertadora. Mas, não é um capital isento aos conflitos, não é um capital que necessariamente se ampliará. É necessário cuidar do mesmo, respeitar seus limites para poder ampliá-los. Eles alertam com essas observações para uma radicalidade política que deixe de lado o aspecto religioso, os dois devem andar juntos, afinal a religião se coloca na fronteira com o sobrenatural, com a vida após a vida. Comporta o político, mas não deve abandonar sua justificação última que é a vida após a vida.

Essas reflexões são feitas para chamar a atenção para dois pontos fundamentais: a presença da esquerda na base, presença de alguma maneira respaldada pela Igreja de Crateús, e a ação continuada da Igreja conservadora, senão largada, mas com sua ação tradicional nas paróquias entre os fiéis sem restrições. Na primeira, veem o perigo das precipitações e práticas muito mais condizentes com as ideologias que professam, muitas vezes contrárias a tradição cultural e que por isso podem causar rupturas e tornar o processo de caminhada incompreensível para o povo, confundindoo, e como diz Mesters, afastando-o das práticas renovadas da Igreja que se quer povo. Na segunda posição, se não se faz uma crítica à Igreja tradicional, se a permite atuar da mesma maneira de sempre, fortalece essa Igreja, pois na cultura do povo a Igreja cumpre certas funções imprescindíveis, como à de salvação das almas, preparar os homens para a vida após a vida, que ao cuidar do político e da ação coletiva a Igreja renovada deixa de fazê-lo, ou a coloca em segundo plano.

Para Comblin (1971), a igreja tradicional só se fortalece e, pela ausência de ação, não se desgasta ao longo do tempo, "os conservadores nada fazem, não se cansam e ficam recolhendo o prato depois da saída dos outros."( p. 14) Não se renovando, não colocando em questão o que está posto, não incorrendo em discussões e debates nem sempre compreensíveis para a maioria do povo, não corre o risco de perderem posição, pelo contrário só se fortalecem pois, segundo o próprio Comblin, a igreja é um espaço, na visão dele, talvez o único espaço que o povo encontra para refugiar-se, "talvez o 
último, em que as classes populares podem existir socialmente, exprimir sua identidade e ter uma cultura própria. Nas áreas da vida social e pública elas são puro objeto de forças que não podem nem conhecer." A igreja para eles é consolação e esse refúgio eles não podem perder como bem o diz Comblin, e quem o oferece é a igreja tradicional.

Voltar a Ranciére (1996) é fundamental nesse ponto, e nele me apoiarei para discorrer criticamente sobre a prática da Igreja de Crateús. Ele diz que a política é dissídio, conflito que provoca pela expressão do outro, daquele que não tem fala, tornar-se visível, expor-se ao confronto, assumir o confronto, impor pautas até então não sugeridas. Será que os camponeses em Crateús estavam dispostos a expor-se? A confrontar os poderosos? A maioria não dispõe de terra, não tem crédito, mas precisam sobreviver e para tanto a possibilidade de vida estava na sujeição, que era o que os proprietários ofereciam. Quantos estariam dispostos a esse confronto? $\mathrm{O}$ sindicato com sua atuação, com sua discussão sobre a legislação trabalhista, de proteção dos trabalhadores rurais, seria capaz de sustentar a fala dos sem fala? A igreja conciliar seria capaz de sustentar a fala? As adesões ao movimento de atuação política e religiosa de $\mathrm{D}$. Fragoso seriam expressão de que a Igreja ofereceria essa proteção aos dissidentes?

D. Fragoso não atuava apenas, mas refletia sobre a sua ação e a ação de sua Igreja. É interessante verificar a insistência dele para que as pessoas escrevessem sobre suas experiências, sobre a experiência de Crateús, refletissem criticamente procurando caminhos, saídas para os impasses que surgiam ao longo da caminhada, era possível que ele soubesse das limitações que se impunham à construção de uma nova visão de igreja e de sociedade. Não era, acredito e procurarei analisar ao longo deste trabalho, desconhecido por ele que a repressão seria mais intensa, e o fora, e que talvez ela fosse muito mais arrasadora se o caminho seguido pelos movimentos, das grandes manifestações, iniciadas desde o começo de seu governo à frente da Diocese, continuassem. $O$ movimento estudantil pagou um preço muito alto em 1968 e nos anos seguintes, da mesma forma o 
movimento sindical teve suas baixas com o recrudescimento da repressão pós 1968. Ele tinha conhecimento disso, e foi alertado por Comblin das novas formas de organização encontradas pela Igreja da Libertação. Se não se podia partir para o confronto direto porque se ficaria exposto à repressão, outros caminhos deveriam ser buscados. E Comblin sugere o caminho das comunidades $^{31}$.

As CEBs são pequenas comunidades, locais, com pessoas conhecidas e que vivenciavam os mesmos problemas. Sua intenção era procurar soluções para os problemas que se vivia. Nesse caso, não havia como reprimir pleitos que levantavam questões sobre os problemas imediatos, não havia como reprimir pessoas que debatiam sua realidade, inicialmente local, regional e, depois, nacional. Não tinha como reprimir comunidades que não dispunham de doutrinadores e líderes carismáticos, a fala era de cada um e de todos. Mesmo que, segundo alguns autores, o agente faça o papel de coordenador e liderança, ou animador, sua presença na comunidade é diluída e, na medida em que atua como os demais, sua presença não significa, com o correr dos anos, mais do que a presença de cada um. A comunidade é uma unidade de iguais onde cada um fala e é ouvido por todos. Seu objetivo é elevar o grau de consciência e articulação de cada um. As Comunidades Eclesiais de Base são espaços públicos e, como diria Arendt, são espaços da fala onde se emitem opiniões a partir do lugar de cada um e, que, através do diálogo, da exposição das opiniões se eleva a compreensão de mundo de todos, o senso comum se eleva a condição de concepção de mundo a partir da qual se olha o mundo de modo diferente para depois se expandir com novas questões e novas respostas.

\footnotetext{
31 “... . Daí uma abertura muito grande para a formação de comunidades eclesiais de base. $\mathrm{Na}$ circunstância atual, é bom tudo que mantêm a identidade do povo, a possibilidade de ser como homem, tomando iniciativas, formando comunidades, buscando fins comuns, fazendo projetos." ( COMBLIN. Testemunhos de Amigos. CAD. Fazendo a nossa história, Diocese de Crateús, 1971, p. 9)
} 


\section{CAPÍTULO II}

\section{DESENVOLVIMENTO DE COMUNIDADES E RENOVAÇÃO DA IGREJA}

As Comunidades Eclesiais de Base foram, nos anos de 1964 até os anos de 1990, a grande novidade. Criadas e estimuladas por segmentos da Igreja Católica, envolveu a participação de pessoas que se sentiam oprimidas ou destituídas de direitos mínimos de cidadania. Aliás, não é surpresa para ninguém que os segmentos populares não participavam da vida política do País, senão acompanhando as ações dos segmentos dominantes, principalmente no campo. Seu papel era respaldar os pleitos dos 'grandes', garantir seu bocado na trama política dos anos anteriores ao ano de 1964, ano do golpe militar, que vem com o objetivo de barrar a mobilização dos segmentos populares estimulados pela ação do Partido Comunista do Brasil, pelo Partido Trabalhista Brasileiro, Partido Socialista Brasileiro e pela Igreja Católica, de segmentos dessa Igreja que estavam mais envolvidos no processo de acompanhamento e organização dos camponeses na busca dos direitos fundamentais, tais como o direito ao trabalho, à educação, à saúde, à organização trabalhista e tantos outros presentes na sociedade, mas ausentes entre os camponeses.

A literatura é farta na análise das décadas anteriores à década de 1960 . Toda ela revela, de maneira extensa, a ausência da população trabalhadora brasileira $^{32}$, principalmente a do campo, nas decisões políticas. Acredito que se possa dizer, e é dito por muitos, que a sociedade civil brasileira era constituída apenas pelos proprietários, os não-proprietários apenas participavam como elementos secundários para respaldar, através da força, as posições políticas dos segmentos dominantes. Nesse sentido já fala Fernandes (1979), Nunes Leal (1986), Martins (1995) e tantos outros. Nunes

\footnotetext{
${ }^{32}$ Isso não quer dizer que a população trabalhadora não se organizasse, mas suas formas de organização eram ilegais e portanto perseguidas pelas forças repressoras do Estado. Exemplo disso é a história do anarcosindicalismo e do Partido Comunista Brasileiro, postos à margem, suas lideranças perseguidas etc. Para uma melhor análise do movimento dos trabalhadores urbanos ver Ítalo Tronca em A Revolução de Trinta, a Dominação Oculta, Werneck Vianna em O Liberalismo e Sindicato no Brasil, Souza Martins em Os Camponeses e a Política no Brasil.
} 
Leal se refere inclusive aos "currais eleitorais"33 controlado pelos "coronéis"34 que definiam e determinavam a posição assumida pelos seus agregados. Não se discutia a melhor posição das oligarquias políticas, mas os vínculos mantidos, os favores a serem pagos com o voto e com a defesa, às vezes armada, das posições dos compadres. Vínculos que vão sendo quebrados ao longo do processo de modernização da sociedade brasileira e, principalmente, da agricultura brasileira.

Martins chama a atenção, ao se referir à abolição da escravatura e na passagem da monarquia para a república, para a presença sempre estranha do campesinato na esfera política, nunca integrado como cidadão, sempre como agregado a respaldar os interesses do outro:

No plano político, a República consolidava a ampliação da cidadania na abolição da escravatura. Levantava a interdição de direitos eleitorais para o liberto e ao mesmo tempo eliminava o preceito restritivo de renda líquida mínima para os diferentes graus de participação política, tanto na definição da elegibilidade quanto na de eleitor. Mas, ao mesmo tempo, instituía a restrição do voto aos analfabetos, mantendo a que se referia ao voto dos mendigos. Isso de fato ampliava a participação eleitoral mas não na mesma extensão da igualdade formal decorrente da generalização do trabalho livre. (MARTINS, 1995, p. 45)

É surpreendente a forma cínica com que se estabelecem as restrições à participação política ou ao exercício da cidadania. Os pobres, os negros, os camponeses, se antes não podiam votar porque eram escravos ou não

\footnotetext{
${ }^{33}$ Currais eleitorais: espaços populacionais sobre os quais os políticos detêm o poder político eleitoral. O exercício do poder ocorre em função do acesso que os políticos ou coronéis tem junto ao poder público, servindo de intermediadores para o reconhecimento dos direitos civis.

34 "Como indicação introdutória, devemos notar, desde logo, que concebemos o coronelismo como resultado da superposição de formas desenvolvidas do regime representativo a uma estrutura econômica e social inadequada. Não é, pois, mera sobrevivência do poder privado, cuja hipertrofia constituiu fenômeno típico de nossa história colonial. É antes uma forma peculiar de manifestação do poder privado, ou seja, uma adaptação em virtude da qual os resíduos do nosso antigo e exorbitante poder privado tem conseguido coexistir com um regime político de extensa base representativa." (V. Nunes Leal, 1986, p 20) Mais adiante o autor esclarece: "Por isso mesmo o coronelismo é sobretudo um compromisso, uma troca de proveitos entre o poder público, progressivamente fortalecido, e a decandente influência social dos chefes locais, notadamente dos senhores de terra. Não é possível, pois, compreender o fenômeno sem referência à nossa estrutura agrária, que fornece a base de sustentação das manifestações de poder privado ainda tão visíveis no interior do Brasil." Gostaria de acentuar que perdura ainda hoje formas de dominação eleitoral, mesmo em espaços urbanos, ou se poderia dizer, principalmente em espaços urbanos já que declinou a população rural. O mando é o mesmo e ao lado dele desenvolvem-se os currais eleitorais
} 
tinham renda mínima para o exercício da cidadania, depois, com a cidadania ampliada, não podem votar porque analfabetos. Lembro que a educação no Brasil era restrita aos ricos e aos que viviam nos centros urbanos, sendo assim, permaneciam de fato as mesmas restrições.

Acredito, como Fernandes, Martins (1995), e Queiroz, que a impossibilidade de inserção na esfera política faz com que os camponeses, em suas manifestações de defesa dos seus interesses, só possam manifestar-se através da rebelião, do levante, muitas vezes armado, ou através das formas religiosas, quando criavam "sociedades alternativas' compartilhando uma ordem da qual eram sujeitos e cidadãos plenos.

Nesse processo, muitos camponeses, principalmente as gerações mais jovens, acabaram migrando em direção aos centros urbanos que se modernizam no processo de industrialização e os atraem em função dos salários pagos e de uma legislação trabalhista que os protegem como trabalhadores-operários. Esses jovens saem do campo também por não encontrarem espaços para a produção de uma agricultura camponesa nas terras, já cercadas pelo latifúndio, monocultor e modernizado no uso de práticas agrícolas mais 'racionais'.

Esses são motivos que levam inclusive a Igreja, a voltar-se para o campo. O processo de emigração significa a desestruturação das famílias, da base familiar que segundo a Igreja, mexe com os valores que norteiam as famílias camponesas, extremamente religiosas. Nas cidades, parte dos jovens migrados, em função da atividade a que se submete na produção, na relação com os outros trabalhadores já urbanizados, acaba por assimilar a doutrina revolucionária marxista, transformando-se em militante comunista, ou base do Partido Comunista Brasileiro.

Em parágrafo anterior, afirmei que os segmentos populares estavam à margem da política partidária ${ }^{35}$ e que somente entravam nela através dos

\footnotetext{
${ }^{35}$ Senti a necessidade de adjetivar a palavra política nesse momento porque no trabalho como um todo considero a mesma como inserção de um segmento social, ou de um indivíduo enquanto expressão de
} 
segmentos dominantes. Claro que me referia ao campesinato, pois os operários brasileiros, principalmente nas cidades como o Rio de Janeiro e São Paulo, liderados por anarquistas e comunistas há muito se manifestavam a partir do seu espaço de trabalho, dos organismos representativos das suas categorias profissionais e através de partidos como o Partido Comunista Brasileiro. Desde muito pleiteavam participação política efetiva, com representantes nos legislativos brasileiros, o que conseguiram a partir dos anos de 1945/1946. De qualquer maneira, a representação comunista consegue ficar na legalidade por curto espaço de tempo, sendo logo posta na clandestinidade. Mas, mesmo clandestina, continuava ativa nos movimentos sociais e políticos nas décadas seguintes.

O campesinato, por sua vez, não tem a mesma sorte. Sua participação propriamente política ${ }^{36}$ não ocorre antes dos anos cinqüenta do século passado. Sua entrada na política, num primeiro momento, se deu a partir de algumas tentativas dos comunistas de organizarem sindicatos profissionais, ligas e outros instrumentos de organização profissional que pleiteavam legislação específica para o campo, protegendo os trabalhadores rurais nas diversas formas de relações de trabalho assumidas por estes na lida com os proprietários de terra.

Depois, temerosos da presença comunista no campo, a Igreja Católica começa sua atuação a partir da ação de D. Eugênio Sales, ainda padre, no Rio Grande do Norte. Preocupação que se coloca de maneira clara, principalmente pela penetração comunista entre os trabalhadores do campo. D. Eugênio, durante seu bispado à frente da arquidiocese de Natal, cria o Serviço de Assistência Rural. Na mesma década de 1950, em Campanha,

um segmento social, na vida institucional de uma sociedade e no Estado enquanto expressão da mesma. Não significa necessariamente a existência de partidos políticos, mas, observando o conceito mais largo de Arandt, espaços públicos onde a fala de cada um e de todos é considerada contribuindo para a reformulação de concepções de mundo e ampliação do senso comum. Ou ainda como diz Rancière a política como litígio, como momento de afirmação do povo, daquele que está à margem e força a ampliação dos limites da sociedade e do Estado.

36 A referência a participação política do campesinato quer referir-se a participação através de mecanismos institucionais como os partidos políticos, os sindicatos, as diversas associações profissionais e religiosas. Não se pode negar, no entanto, que se afirmava como sujeito da política, não estou me referindo ao conceito de pré-política, da política como expressão de uma consciência que se afirma e ocupa lugar, presença como se depreende das concepções de Arendt e Rancière. 
Minas Gerais, o bispo D. Engelke faz uma reunião com proprietários de terra, professores e religiosos para discutir a situação do homem do campo no Brasil e a ameaça comunista. Para ele, a Reforma Agrária, grande pleito dos trabalhadores rurais brasileiros, seria feita, sendo assim que fosse feita com o apoio da Igreja e dos proprietários para que não ganhasse coloração radical enfatizada pelos comunistas na sua ação no meio rural.

Apoiado em Ricci (1999) e em Ammann (2003), acredito que esse começo de uma ação social da Igreja voltada para o campo, observava uma preocupação que não era unicamente da Igreja Católica, era uma preocupação também dos governos brasileiro e norte-americano. Este último país, preocupado com a expansão comunista nos países da América Latina, promove convênios e dispõe recursos para ações desenvolvimentistas e modernizadoras no Brasil a partir do desenvolvimento das comunidades rurais. Esse trabalho tem a presença da Igreja, aliás, não poderia ser desenvolvido sem a ação conjunta da Igreja Católica na medida em que se reconhecia no Brasil uma população quase que absolutamente católica.

As premissas sobre as quais o desenvolvimento de comunidades está assentado são conservadoras. Os programas estabelecem em primeiro lugar a possibilidade do desenvolvimento e através dele a melhoria nas condições de vida do homem do campo. Em segundo lugar, que o desenvolvimento de comunidades envolve todos os segmentos da comunidade, independente de sua posição no processo produtivo, as pessoas podem alcançar o bem estar, a satisfação de suas necessidades e o equilíbrio necessário à vida em comum, aliás, sem esse equilíbrio, sem a cooperação entre as partes, não há desenvolvimento e a comunidade não cumpre seus objetivos: propiciar a todos as condições necessárias ao bem viver.

É interessante frisar que a comunidade aparece como um todo, indivisível, identificado com objetivos comuns e espaço de vida e atuação dos seus membros em convivência que denota a unidade na pluralidade. Poder-se-ia comparar a um corpo vivo onde todas as partes são necessárias ao bem do corpo social. Assim, trabalhadores, proprietários e governo são partes 
necessárias do todo, somente nessa diversidade capazes de fazer funcionar em equilíbrio o conjunto social. Os trabalhadores com seu trabalho, com sua atividade produzindo aquilo que é necessário à comunidade, os proprietários com as iniciativas disponibilizando para os trabalhadores os meios necessários ao desenvolvimento do seu trabalho e da produção, bens que a iniciativa dos proprietários adéqua às necessidades do mercado, garantindo a sua comercialização no entorno, sociedade global. E o governo com seus técnicos cuidando para que os trabalhadores e empresários tenham o treinamento e recursos necessários à produção de bens e serviços. Aplicamse os princípios de solidariedade e cooperação entre as classes sociais, mediadas pelo governo, para a obtenção de desenvolvimento social e econômico.

Por fim, o desenvolvimento de comunidades implica no esforço comum de comunidades no interior da sociedade maior, como se fossem mundos particulares onde o esforço de todos leva ao desenvolvimento equilibrado e harmônico entre as partes. Desse modo, desconhecem-se os conflitos entre trabalho e capital, ignoram-se as contradições entre as classes e as demandas pessoais para afirmar o coletivo. Não são e não pretendem a política como espaço de debate entre partes antagônicas, não percebem nem acentuam as diferenças, são mundos, são comunidades plenas em si mesmas, diferentes das outras por suas potencialidades próprias que devem ser buscadas pelo conjunto. É na concretude das comunidades que se devem procurar as barreiras e os empecilhos ao desenvolvimento humano e a Igreja entra nesse processo como instituição capaz de promover a paz, de garantir a harmonia, ao mesmo tempo, que articula o desenvolvimento de comunidades com a visão cristã da igualdade entre os homens, da piedade e da caridade. Afinal, as comunidades remetem ao cristianismo dos primeiros cristãos, se fizermos uma leitura atualizada das comunidades cristãs primitivas onde se priorizava a vida em comum, compartilhada.

Portanto, não era estranha a presença da Igreja, ela inclusive é requerida, a meu ver, por sua rede de paróquias e padres espalhada em todos os recantos, por sua doutrina que não se contrapunha ao capitalismo e por seu 
anticomunismo claro. Ela era também requerida em função da experiência como educadora, afinal a Igreja católica detinha parte significativa dos colégios, seminários, jornais e rádios. Seus intelectuais eram competentes na elaboração e reelaboração de concepções de mundo que já se assentavam num conjunto de crenças afinadas com o catolicismo mundial. É bom lembrar que o processo de romanização, ao centralizar as diversas formas de catolicismo existentes em nosso país numa concepção única, o faz assimilando e reelaborando o catolicismo popular, através de uma rede de seminários, paróquias, religiosos e religiosas. Essa é uma estrutura que não poderia ficar fora do processo de desenvolvimento de comunidades; a Igreja, ao constituir em torno de si comunidades de cristãos, já experimentava essa forma de organização social que dirimia, pelo menos no nível da aparência, as diferenças sociais: todos eram cristãos e igualmente filhos de Deus.

Sendo assim, a Igreja não apenas participava dos seminários e encontros promovidos por organismos governamentais, como também os preparava. Gostaria de acentuar que tanto em Natal como em Fortaleza, sob a iniciativa da Igreja, foram criados cursos de serviço social para preparar profissionais capazes de atuar nas comunidades, coordenar as reuniões e preparar ideologicamente o conjunto dos segmentos populares sob a direção das elites renovadas, ou aparentemente renovadas. Da mesma maneira, o envolvimento da Igreja Católica se concretizou na criação de organismos internos capazes de estimular a organização das comunidades. A resposta da Igreja ao chamamento do Desenvolvimento de Comunidades é rápido também em função da preocupação com a expansão comunista e atéia junto aos trabalhadores. Sua preocupação com essa expansão faz com que se volte para uma ação mais afirmativa junto aos trabalhadores rurais, daí partiam aqueles que, por suas condições objetivas, são obrigados a migrarem para os centros urbanos mais desenvolvidos ou em processo de desenvolvimento.

D. Eugênio Sales acreditava que educando, dando uma formação mais sólida ao campesinato, geraria barreiras à expansão marxista. Mas, para ele, 
isso apenas não bastava, seria necessário que se promovesse o desenvolvimento no campo, que se modernizassem as relações de trabalho, se facilitasse $o$ acesso a terra e, principalmente, se fortalecessem os laços familiares. Nesse sentido, se olharmos para as experiências de Natal e do Crato, são criadas algumas formas de organização entre os trabalhadores rurais, juntamente com a $A N C A R^{37}$, órgão de extensão rural, ligado ao governo federal, com presença em todos os estados brasileiros, principalmente no Nordeste. Assim, são criados clubes de mães, de jovens, associações comunitárias e os sindicatos dos trabalhadores rurais.

A idéia que se passa é de que através do desenvolvimento de comunidades, existiria, de fato, possibilidade de se superar as carências e a pobreza delas decorrentes, o que exigiu a participação e o compromisso de todos com o processo de desenvolvimento. Se o subdesenvolvimento existe, ele decorre de um modelo distorcido, pois, a modernização e o desenvolvimento do capitalismo poderiam expandir as oportunidades de investimentos e, consequentemente, gerar mais empregos, mais oportunidades de trabalho, portanto a geração de renda para todos os segmentos da sociedade. Desvios existiam, mas poderiam ser corrigidos pela ação coletiva nas comunidades e a partir delas na sociedade como um todo.

Esse processo de organização de comunidades de alguma maneira coloca a Igreja diante dos impasses e do debate que acontecem na sociedade brasileira. São várias correntes e concepções em enfretamento procurando respaldo para que possa assumir a direção do processo histórico. Debate que provoca reflexões, aprofunda visões, reformula concepções e ações. Mas, é interessante que se diga, que nesse embate não sai incólume nenhum dos participantes. Alguns, como a Igreja, assimilam no embate direto com os comunistas e outros segmentos políticos situados mais à esquerda, assimila, senão a visão de mundo do outro, mas sua metodologia, sua análise do capitalismo na medida em que o desenvolvimento, ao contrário do que se pensava, não levava à superação das carências, pelo

\footnotetext{
${ }^{37}$ Segundo Ammann Associação Nacional de Credito e Assistência Rural - ANCAR
} 
contrário, aumentava a pobreza e a insegurança, na medida em que se modernizava e gerava mais lucro para os empresários capitalistas.

Neste capítulo tratarei dos elementos que, segundo minha análise, contribuíram para uma ação da Igreja mais condizente com as carências de seus fiéis. Em primeiro lugar, a Igreja assume o desenvolvimento de comunidades como uma possibilidade de promover o homem no interior de uma sociedade capitalista, democrática e fundada nas comunidades, na solidariedade e na caridade. Para ela a alternativa que emergia dos conflitos sociais era o comunismo ateu, autoritário e coletivista. Depois, em segundo lugar, a lgreja necessita, para se tornar presente entre os camponeses, lidar com as formas populares do catolicismo, o que também modifica, na minha visão, sua forma de pensar a religião e a lgreja. Nesse caso, repensa o papel do leigo, sua função na Igreja como cristão e, ao fazê-lo, repensa a própria Igreja e sua inserção na sociedade. Por fim, o combate à 'ameaça' comunista, principalmente nos centros urbanos entre os operários e os estudantes. Nesse caso, sua ação é uma ação política, disputa os espaços nas organizações estudantis e operárias já politizadas nos embates com os governos sucessivos e com a elite intelectual e política burguesa.

\subsection{A Ação Modernizadora da Igreja Católica}

O Desenvolvimento de Comunidades, programa que se desenvolve no Brasil a partir de uma parceria entre os Estados Unidos da América e o Brasil, foi criado a partir da Guerra Fria. Após a segunda guerra mundial, preocupada com a expansão do ideário comunista no chamado, desde então de 'Mundo Livre', os Estados Unidos começam a desenvolver programas de ajuda aos países do então chamado Terceiro Mundo, sob sua órbita de influência, para dirimir os problemas mais agudos dessas nações. 
Ammann apresenta essa política desenvolvida pelos Estados Unidos da América da seguinte forma:

Sob o argumento de que 'a pobreza é um entrave e uma ameaça tanto para essas populações (pobres) como para as áreas mais prósperas; de que 'na atual luta ideológica os povos famintos têm mais receptividade para a propaganda comunista internacional do que as nações prósperas'; de que 'o esforço de ajudarem os povos a alcançarem um nível de vida mais sadio e mais economicamente produtivo eliminaria os focos de comunismo em potencial'; de que 'as melhorias das condições sociais e econômicas em qualquer parte do mundo livre redundaria em benefício dos Estados Unidos' este país se proclama líder do mundo pela boca de seu presidente: 'creio que devemos oferecer aos países amigos da paz, afirmava Truman em seu discurso de posse, os benefícios do nosso cabedal de conhecimentos técnicos e ajudá-los a realizar suas aspirações por uma vida melhor. (AMMANN, 2003, p.30)

Essa preocupação, é claro, tinha um viés voltado, segundo alguns analistas, para a formação de mão-de-obra especializada que atendesse ao desenvolvimento tecnológico, que permitisse mais produtividade e consequentemente maior retorno aos investimentos do capital. Acredito, também, que esse processo tinha uma preocupação central em se colocar como ajuda para as populações do chamado terceiro mundo, ou mundo subdesenvolvido, que não tiveram a mesma sorte que os países centrais. Assim, há uma preocupação com a educação, educação que extrapolava o sentido da formação, principalmente da formação para a cidadania, e se centrava na educação profissionalizante. Mesmo quando sua preocupação é ensinar a ler e escrever, o foco é a mudança de hábitos, a racionalização no trabalho e na convivência comunitária. Nesses elementos estão presentes a cooperação, o planejamento e a produção de bens e serviços dirigidos para o mercado.

Pode-se depreender da análise da ideologia do desenvolvimento de comunidades feita por Ammann que a educação é fundamental para:

(...) a expansão da ideologia e do modo de produção capitalista" (p.33) e sendo assim são criadas escolas de serviço social com o intuito de acompanhar e estimular 0 
processo de organização dos camponeses a partir da introdução de mudanças de mentalidade, inovando processos, modernizando práticas e introduzindo a produção racional e técnica mais adequadas a produção para mercado; "... reconhece-se a necessidade urgente de modernizar a agricultura e criar nas áreas rurais condições favoráveis à consolidação do sistema capitalista. Tal postura casa-se perfeitamente com a política definida em âmbito nacional que aponta àquela época em direção à industrialização do país, a qual por sua vez imprescinde da crescente oferta de produtos primários. (IDEM, p. 33)

A Igreja facilmente se incorpora a esse trabalho. Em primeiro lugar, porque ela também via na expansão comunista uma ameaça. Aliás, ela prepara quadros desde os anos trinta para combater, através de jornais e periódicos, as idéias marxistas que se expandem no movimento operário. São criados institutos onde o pensamento cristão é desenvolvido e adequado à realidade brasileira, como resposta ás diversas análises orientadoras da ação dos Partidos Comunista e Socialista brasileiros. Dá-se, nesse sentido, embate constante entre essas visões de sociedade e do homem, da promoção e desenvolvimento do homem e da sociedade e do estado como instrumento de efetivação de direitos e de políticas públicas.

No Nordeste, é bom frisar, a ação modernizadora das arquidioceses de Fortaleza, Aracaju e de Natal, principalmente desta última, que cria o Serviço de Assistência Rural para atuar no campo, com o intuito de evitar a assimilação da propaganda comunista. É interessante ressalvar a fala de D. Eugênio Sales, que afirma ser necessário atuar no campo para evitar que as populações urbanas do futuro aceitem a ideologia marxista. Criar no campo uma mentalidade mais resistente, mais cristã que rejeite a propaganda marxista atéia, o proselitismo das outras igrejas e a ação radical das Ligas Camponesas.

Enquanto força política, a Igreja conseguiu neutralizar outras forças que também disputavam a hegemonia das lutas dos trabalhadores no momento. Uma delas foi o Partido Comunista Brasileiro, que, aliás, desde a década de 1940 vinha desenvolvendo uma estratégia objetivando organizar o trabalhador rural em associações, ligas e sindicatos, na tentativa de dar uma direção às suas lutas. (CRUZ, 1985, p. 69) 
Portanto, para D. Eugênio Sales, o trabalho a ser desenvolvido pela Igreja era voltado para a família e para as comunidades rurais. A intenção era promover integração e a cooperação, a modernização não excludente, mas que garantisse a terra para produção familiar e uma legislação trabalhista que protegesse os trabalhadores rurais, dentro da legalidade, portanto.

No Crato, encontra-se um dos trabalhos da Igreja mais completamente afinados com as propostas expostas acima. O bispo do Crato, D. Vicente de Araújo Mattos, cria a Fundação Pe. Ibiapina. Nessa fundação concentra toda a ação para o homem do campo, e a partir dela são criados clubes de mães, de jovens, de produtores, associações e sindicatos de trabalhadores rurais. Nela também é criada a Escola de Líderes Rurais que tem como preocupação a formação de lideranças afinadas com a Igreja. São ministrados cursos de liderança, de legislação trabalhista, de agentes de saúde comunitário, de sindicalismo, de corte e costura e tantos outros, passando para os jovens que os frequentam uma visão cristã do mundo, claro que uma visão definida e determinada pela própria Igreja enquanto instituição humana, com opções claras quanto aos caminhos que as sociedades ocidentais devem seguir.

A preocupação com o campo se acentua na medida em que começam a emergir formas de organização e luta, independentes ou ligadas aos partidos considerados de esquerda. Não se pode esquecer a ação do PCB na criação de confederações, federações e sindicatos de trabalhadores rurais e a ação do Partido Socialista Brasileiro na organização das Ligas Camponesas. Desse modo, avança a Igreja na proposta de criação dos sindicatos e na divulgação de bandeiras como a da Reforma Agrária. Antes que se expanda a luta pela reforma agrária radical, como proposta pelas Ligas, a Igreja propõe outro modelo que vai no sentido da modernização capitalista: divisão da terra, assistência técnica, produção moderna a partir do uso de máquinas e voltadas para o mercado. Portanto, articulada com o processo de modernização e industrialização propostas pelo desenvolvimento do capitalismo no Brasil. O próprio Celso Furtado associa a 
reforma agrária ao desenvolvimento da industrialização dos centros urbanos. As áreas reformadas seriam áreas de produção de alimentos baratos para os centros urbanos, barateando com isso os custos de mão-de-obra. Sendo assim, seriam as áreas reformadas áreas de produção racional e técnica, modernas, portanto, articuladas à indústria nascente como mercados para a absorção de máquinas agrícolas e outros insumos industrializados. Situação que quebraria com a agricultura tradicional, familiar, capaz de economizar braços que seriam posteriormente aproveitados como mão-de-obra da indústria nascente.

São várias correntes em confronto na sociedade brasileira que vão paulatinamente se condensando e conflitando na ação concreta sobre a população rural. Lembro que desde as duas primeiras décadas do século XX vai se consolidando uma visão modernizadora do campo via criação de Faculdades de Agronomia. Essa concepção de desenvolvimento rural, expressado, segundo Mendonça (1996), no movimento ruralista, associada ao desenvolvimento do capitalismo mundial, passa, segundo a autora, pela ideologia divulgada pelos segmentos dominantes de que o Brasil tem uma vocação, definida e determinada por sua extensão e por sua localização tropical, para a agricultura. Não sei se essa concepção tem a ver com a oposição de interesses da elite industrial, com a elite agrária, cada uma procurando definir o estado de acordo com seus interesses e, claro, submetido aos interesses desses segmentos em conflito, que segundo Fernandes, não seriam tão conflitantes assim, na medida em que os capitais usados no processo de industrialização, pelo menos o processo iniciado no final do século XIX, teria se dado em função dos capitais oriundos da atividade rural. Mas acredito que, na medida em que vão se consolidando esses capitais, com certeza os atritos vão ocorrer pela predominância de um setor sobre o outro na determinação das políticas dos governos republicanos de então.

Engana-se quem acredita que a visão ruralista expressa nesse movimento seria conservadora, pretendesse uma restauração da plantação nos moldes anteriores à república. $O$ que se pretendia era a modernização da 
agricultura, considerada a vocação natural do Brasil, nos âmbitos da grande propriedade, da média e da pequena propriedade, cada uma delas com sua vocação própria de atendimento aos mercados externos e aos mercados internos; e a pequena e a média voltadas para a produção de alimentos (MENDONÇA. 1996, P. 181). Esse projeto, no fundo, era o mesmo projeto de modernização do campo proposto pela Igreja. Consolidar a economia nacional, afirmar a produção familiar moderna, com capacidade de assegurar a sobrevivência das mesmas e demonstrar que os interesses dos setores agrícolas exportadores ou dos grandes produtores rurais não estavam na contramão do desenvolvimento dos pequenos produtores rurais, pelo contrário, seriam complementares.

Claro que a modernização que se consolida não é aquela proposta na velha república. Em algumas localidades do interior do país, a modernização posta em prática muito mais para atender aos interesses da indústria nascente vai provocar migrações e vai desestruturar a agricultura familiar, escasseando as terras para a agricultura camponesa. Poder-se-ia dizer que a visão de desenvolvimento rural posta em prática pelo desenvolvimento de comunidades se assemelha à visão dos ruralistas. Ela irá propor que a modernização da grande propriedade de terras incida também sobre as médias e pequenas propriedades rurais. O importante é especializar a atividade agrícola por grupo de áreas, de modo que a grande propriedade se especialize na agricultura de exportação, as médias e pequenas se voltem para a agricultura de alimentos, principalmente para atender ao mercado interno.

A Igreja incorpora esse modelo e passa a atuar com ênfase no campo a partir de diretrizes que emanam de encontro realizado em Minas Gerais, sob a orientação de D. Egelke. Segundo Martins (1995), esse encontro foi realizado com a presença da Igreja, sua hierarquia, professores e fazendeiros. Essa configuração dos presentes revela, em primeiro lugar, que a Igreja assume uma postura conservadora de manutenção da ordem e da paz numa sociedade capitalista capaz de promover o desenvolvimento e a modernização das relações de produção no campo. Depois, que o Estado, 
através dos professores rurais, assume responsabilidade condizente com sua função de, através da educação, manter a unidade nacional ameaçada pela presença dos comunistas. Mas, a educação não é apenas ministrada pelo Estado, também é desenvolvida pela Igreja, através de colégios espalhados em todo o interior do país e pela ação de bispos que assumem a educação no campo através de institutos e fundações. Como é o caso de Natal e do Crato, educação que não é formal, mas uma educação profissional voltada para as atividades complementares às atividades agrícolas. Não se deve esquecer a formação sindical que em parte se faz no Brasil através da Igreja.

Mas, o papel da Igreja vai mais longe. Seu papel educador não se encerra nas escolas e nas fundações, ele perpassa o culto, com as pregações diárias, no trabalho de catequese e nos organismos de base que são criados por ela no campo. É uma presença bastante generalizada e ramificada que se apóia numa visão de sociedade integrada, cooperativa e solidária, enfim, uma sociedade que privilegia a paz social apesar das diferenças. Nesse encontro, D. Inocêncio Engelke chama a atenção para a questão da reforma agrária: "Com nós, ou sem nós, ou contra nós ela será realizada"38. Tal chamada de atenção tem um alerta para a urgência da ação da Igreja e dos proprietários para as necessidades do homem do campo, dos problemas que são vividos por eles e a necessidade de resolvê-los, antes que os comunistas sublevem a sociedade.

As comunidades são uma base para 0 trabalho da Igreja e o desenvolvimento de comunidades será a ideologia que irá permitir a unidade e a paz no campo, ao mesmo tempo, evitará o proselitismo comunista que tem por base a exploração do trabalho pelo capital, a opressão e a ausência de direitos que efetivamente favoreçam o homem do campo. Para a Igreja, ou se modernizam as relações de trabalho no campo, se melhora as condições de vida dos trabalhadores ou os trabalhadores se levantarão, basta ver o exemplo das Ligas Camponesas. E a ação da Igreja se faz

\footnotetext{
${ }^{38}$ Citado por MARTINS, José de Sousa, in, Os Camponeses e a Política no Brasil. 1995. P
} 
exatamente para se contrapor às iniciativas que se colocam contra a forma capitalista de produção, modo de produção capaz de atender, através do desenvolvimento, as carências dos mais pobres. O Desenvolvimento de Comunidades, segundo a Igreja, e por isso ela se envolve com o processo de organização de comunidades, é a melhor maneira de suprir as carências e a pobreza, é a melhor forma de desenvolvimento por garantir a cooperação entre trabalhadores e empresários, afinal essas classes necessitam da cooperação uma da outra. Para RICCI (1999)

Havia um agrupamento político no interior da Igreja Católica que organizava encontros cuja tônica era a valorização da família rural como unidade econômica, de suas características de povo conservador e desconfiado, em que se pregava a introdução de máquinas e o 'financiamento por intermédio de cooperativas para soerguer-Ihes o ânimo. (p. 55)

Mais adiante Ricci mostrará a relação da Igreja com a ONU na implementação do desenvolvimento de comunidades:

Na década de 1950, a ONU estimulou o esforço educacional e modernizador do terceiro mundo utilizando-se do conceito de comunidades com o objetivo de unir 'os esforços do próprio povo [...] aos das autoridades governamentais, com o fim de melhorar as condições econômicas, sociais e culturais das comunidades, integrar essas comunidades na vida nacional e capacitá-las a contribuir plenamente para o progresso do país. Chegou a afirmar a necessidade urgente de modernizar a agricultura, criando-se condições para a consolidação do capitalismo moderno.

A participação de setores da lgreja neste processo foi intensa. A União Católica Internacional de Serviço Social promoveu, sob o patrocínio da UNESCO, o Seminário de Educação de Adultos para o Desenvolvimento de Comunidade, em 1957, que reforçou a necessidade do trabalho nas comunidades rurais a partir dos novos imperativos internacionais. (Idem, p.56)

No desenvolvimento de comunidades, está um dos elementos que depois possibilitaram o aparecimento das comunidades eclesiais de base, isto porque cria uma base comunitária, aproxima as pessoas na discussão de suas carências e potencialidades e, na medida em que são frustradas, na percepção mais crítica dos direitos: para quem estão dirigidos os direitos, quem são os destinatários dos mesmos e os limites da participação. Os 
técnicos envolvidos no processo também passam a perceber que o desenvolvimento de comunidades, em seu formato inicial dos anos cinquenta e sessenta do século passado, não gera oportunidade para os segmentos populares, mas gera a acomodação diante dos entraves que dificultam a ação popular. Da mesma maneira que gera desconforto na Igreja, principalmente entre religiosos, na medida em que percebem que 0 desenvolvimento no campo gera mais desemprego, são as máquinas substituindo o homem, rompendo com as relações tradicionais que, no mínimo, possibilitavam ocupação e terra para a produção de alimentos.

\subsection{A Inserção da Igreja na Sociedade: construindo uma nova Igreja}

Durante as décadas de 1960, 1970 e 1980, em várias ocasiões, a Diocese do Crato foi acusada de favorecer os grupos dominantes e não apenas por pessoas ligadas às bases, mas também por suas equipes, principalmente a equipe que constituía a Escola de Líderes Rurais, da Fundação Padre Ibiapina. Em 1981 o grupo que constituía a Escola de Líderes Rurais rompe com a Igreja e cria uma entidade, a Associação Cristã de Base, que assume o papel de organizar os camponeses no Cariri Cearense. Analisei esse processo em minha dissertação de mestrado (ALBUQUERQUE, 1991), revelando que a grande maioria dos membros da equipe da ELIRUR era oriunda do campo, filhos de pequenos proprietários rurais e, portanto, solidários com o destino dos camponeses naquela região do Ceará.

O rompimento da equipe da ELIRUR com a Diocese não foi uma ação restrita ao grupo. Ele contou com o apoio de líderes rurais formados pela escola ao longo dos anos. Esse é um momento em que aparece o caráter contraditório da Igreja Católica. Mesmo uma Diocese de orientação conservadora acaba por disseminar, na medida em que se relaciona com o mundo externo e interno, concepções contraditórias, às vezes opostas, da Igreja e da sua mensagem salvadora. Não há como impedir que pessoas estranhas às bases se relacionem com elas através do movimento sindical e partidário. Sendo assim, as bases são contaminadas. A realidade conflita 
com a leitura mais conservadora que faz a Igreja se aproximando mais daquilo que é posto pelos outros, comunistas e demais segmentos de esquerda.

A própria Igreja se renova. O Concílio Vaticano II, Medellim e Puebla, são eventos que repensam a Igreja e sua inserção nos países pobres do terceiro mundo. Torna-se mais crítica, revê as relações de troca internacionais que favorecem sempre os países desenvolvidos em detrimento dos países do terceiro mundo. A Igreja percebe que tem papel fundamental no processo de libertação dos povos, que não pode compactuar com os poderosos no processo de exploração dos demais países. Sua visão de sociedade se aproxima da visão marxista mesmo que ainda exerça a crítica ao comunismo. Percebe, também, que não pode falar de promoção humana sem superar as relações capitalistas de produção. Para ainda manter influência sobre os povos, principalmente entre os povos do chamado terceiro mundo, ela terá que mudar sua prática, mas essa mudança não se caracteriza apenas com a finalidade de manter-se como instituição mundial, com poder e força suficientes para ser levada em conta na repartição dos benefícios que o poder permite. Existe a consciência de uma instituição religiosa com uma mensagem universal, fundada na palavra revelada que transcende o mundo temporal, mas que se assenta nele.

Essa condição e a inserção a partir dessa condição de ser religião, expressão dessa mensagem transcendental que se assenta na salvação do homem, criatura por excelência, expressão do Deus salvador, necessariamente leva à ação, ao mesmo tempo, que limita e determina os comportamentos de seus seguidores. A Igreja não pode justificar qualquer coisa, não é pura e simplesmente uma instituição a serviço das classes dominantes, para justificá-la diante dos explorados, ou justificar as relações de produção prevalentes. Mas, também, não é uma instituição fora da história, ela é histórica, situada e em constante processo de construção. Como diz Engels na sua introdução ao livro de Marx, "A Luta de Classes na França", ela foi revolucionária nos primeiros séculos da nossa era, para depois transformar-se em religião de Estado. Mas, mesmo sendo religião do 
Estado, o cristianismo produz leituras revolucionárias. Engels revela esse caráter contraditório do Cristianismo no seu livro "As Guerras Camponesas", percebe-se, nele, que a Igreja nunca foi um bloco fechado com uma única interpretação da palavra revelada, sempre contou com dissidências, que justificaram levantes contra a ordem, não apenas religiosa, mas também temporal.

Maduro (1983), com base em Gramsci, faz análise interessante sobre a emergência de concepções e de compromissos dissonantes dentro do aparelho religioso, principalmente no interior do catolicismo. Para ele, não há como evitar outras expressões no interior da Igreja, até porque o corpo hierárquico tem origens diversas, se insere em espaços diversos, interagem com forças sociais também diversas. O olhar que orienta a leitura da palavra, em função de sua origem, está diferentemente orientado, dando origem a percepções que se chocam e levam a ações diferentes e opostas na sociedade civil. Maduro, no entanto, chama a atenção para a orientação dominante no seio da Igreja e que repercute na sociedade civil, nesse caso a força dominante no interior da Igreja coincide com as forças sociais dominantes na sociedade como um todo. A emergência de uma nova práxis religiosa ocorre quando as forças sociais fazem emergir, como predominante ou não, uma práxis social coincidente.

Gostaria de destacar que os anos cinquenta e sessenta do século XX são anos de efervescência popular nas lutas contra o imperialismo, das lutas de libertação das colônias africanas e do movimento sindical. São lutas que emergem em função de processos de modernização tecnológica que substitui o homem pela máquina pela intensificação da exploração do trabalho pelo capital. No Brasil, a industrialização e a modernização do campo modificam violentamente as relações de produção assentadas nas parceiras e no apadrinhamento, forma cultural que estabelecia laços afetivos entre trabalhadores e os proprietários. Rompidos esses laços, fremidos por necessidades de espaços de trabalho e a instauração de relações impessoais de trabalho, os trabalhadores se levantam, se organizam e 
procuram alternativas políticas. Aparecem no contexto da política e aparecem, como diz Rancière (1996), como partes litigantes.

Martins (1994), por sua vez, interpreta a inserção da Igreja Católica como uma consequência, também, da vinda para o Brasil de padres europeus que vivendo outra realidade viriam à situação do trabalhador brasileiro como uma situação de iniquidade. Nessa perspectiva, não emerge outra visão de Igreja e sociedade, apenas um olhar a partir do lugar de origem. A luta pelos direitos em algumas categorias sociais e populares decorreria desse olhar diferente, a Igreja assumiria uma posição de apoio e luta conjunta pela consolidação dos direitos sociais.

Nessa perspectiva, é necessário rever criticamente algumas concepções utilizadas com excessiva facilidade para explicar o envolvimento dos bispos e dos agentes de pastoral nas difíceis situações dos camponeses e dos índios. Porque tais concepções são estratégicas e comprometem toda a explicação do processo histórico da Igreja. O conceito mais comum tem sido o de 'conversão'. Por meio dele, fica mais fácil explicar porque um bispo 'conservador' se torne, às vezes quase subitamente, um bispo 'progressista'. Isto é, um bispo rotineiramente devotado a uma prática sacramental, em determinado momento, passa a pôr em prática uma pastoral social e popular. Rigorosamente falando, essa concepção não dá conta do processo real que leva o bispo, bem como o sacerdote e a religiosa, a assumir corajosamente a defesa da vida de um grupo indígena ou de uma comunidade camponesa vinculados pela sua remoção ou pela sua expulsão violenta das terras que ocupam. (...)

Essas concepções distorcem completamente o sentido da ação pastoral e de sua relação com as condições sociais e históricas da qual resulta. Além do mais, deixam de lado as mediações (inclusive a mediação institucional da Igreja e da religião) que tornam peculiar a relação de sentido entre a posição social (e institucional) do bispo (e do agente de pastoral) e sua ação, mesmo na gênese de princípios doutrinários, que depois se fixam em textos de interpretação e orientação coerentes e articulados. (MARTINS, 1994. P. 97)

Mais adiante 0 autor complementa sua percepção das aparentes incongruências da ação dos religiosos ao afirmar:

Elas sugerem, equivocadamente, que o bispo e os agentes religiosos atuam no sentido da história quando se tornam incoerentes; quando, supostamente, rompem com a linha de 
atuação e de interpretação da sua prática e do lugar dela no mundo. Entretanto, a interpretação dessas aparentes descontinuidades e rupturas, desses aparentes saltos e 'conversões', ganha em perspectiva e riqueza de compreensão quando considera que o trabalho pastoral, numa sociedade convulsionada como esta, incide diretamente sobre contradições sociais, sobre desencontros históricos, rupturas profundas, realidades sociais cujos ritmos não convergem. Numa situação social assim, a coerência ética e religiosa é que pode mobilizar a denúncia, e não mais a conivência; pode mobilizar a solidariedade com a vítima e não com o opressor. É que ela impõe a necessidade de uma redefinição da ação pastoral, o resgate do sentido profundo e profético permanentemente contido, como possibilidade objetiva e necessidade, no trabalho pastoral, com os excluídos, com as vítimas. (MARTINS, 1994, p. 98)

É nesse contexto de múltiplas visões de Igreja, de múltiplas realidades sociais, que ela vai incorporando os leigos. É nesse contexto que também ela vai interagindo com as demais correntes sociais, políticas e filosóficas que permeiam a sociedade civil e que conformam a ação da sociedade civil como um todo. Nesse cruzamento de tantas visões e interpretações de Igreja e sociedade, do Estado e das classes sociais que se consolidam posições, que se configuram alianças e que se modifica a visão da lgreja e de suas correntes internas. A presença do leigo no contexto da instituição Igreja modifica sua presença e sua visão, modificam-se suas práticas; e sua estrutura fortemente marcada pela hierarquia e pelo centralismo torna-se mais democrática e mais permeável às influências externas. Renova-se a Igreja e o Concílio Vaticano II é expressão dessas novas forças que atuam na sociedade e por consequência na Igreja.

D. Fragoso, ao assumir a Diocese de Crateús, o faz a partir da sua história e da história da Igreja, da sua inserção modificada pelas relações externas que se fortalecem internamente mudando posturas e ações. Na sua posse, estão presentes a ação modernizadora e desenvolvimentista da Igreja de Sobral, que assume uma postura de agente do desenvolvimento e da modernidade na figura sempre lembrada do bispo de Sobral D. José Tupinambá da Frota; a ação isolada de padres e leigos, na maioria jovens, com uma prática de Igreja popular, ainda incipiente, a atuarem entre os segmentos mais pobres da periferia de Crateús; e a sua própria história 
como coordenador da Juventude Operária Católica e da Ação Católica Operária, dentro de uma perspectiva de Igreja comprometida com os trabalhadores e segmentos populares na direção da libertação.

O discurso de posse de D. Fragoso é uma tomada de posição; nele afirma que sua Igreja não tem a pretensão nem o desejo de ser uma Igreja civilizadora nos moldes de D. José Tupinambá, e rejeita na conversa que manteve com o governador de então, Virgílio Távora, recursos para implementar ações desenvolvimentistas. Sua Igreja, afirma nesse discurso de posse, diante de uma assembléia de autoridades civis, militares e religiosas ser uma Igreja voltada para os pobres, fermento das lutas e organização dos trabalhadores e apoio de sua caminhada. Essa postura no decorrer dos anos apenas se fortalece, mas esse fortalecimento se respalda na ação das classes populares e na própria Igreja, nos religiosos e leigos que, no interior da Igreja defendem uma postura mais inserida nas questões sociais.

Nessa análise que será aprofundada em capítulo posterior me atrevo a dizer, como o fazem Comblin, Mesters e Boff, que os segmentos conservadores, ainda presentes e sempre fortes no conjunto da Igreja, apóiam esse processo de renovação e de inserção da Igreja, e o fazem não porque compartilham as mesmas idéias, mas por uma questão de sobrevivência da própria Igreja. Afinal não interessa nem aos conservadores nem tão pouco aos progressistas o fracionamento da Igreja em seitas, a Igreja tanto para uns como para os outros somente interessa enquanto forte e respaldada pela sociedade. Doimo (1995) apresenta em seu trabalho sobre os novos movimentos sociais, que a existência desses movimentos se deve ao respaldo que a Igreja conservadora dava às CEBs. Eram destas comunidades que saíam as lideranças dos novos movimentos, como eram dessas comunidades que saíam os informativos que divulgavam os movimentos.

Da mesma maneira que as CEBs, para existirem os novos movimentos sociais, dependiam da força e presença da Igreja conservadora, do seu 
capital, para usar a linguagem de Mesters; os novos movimentos sociais necessitavam do capital e presença das comunidades. A expressão nacional dos movimentos, como o Movimento Contra a Carestia, só era possível nos lugares onde as CEBs eram fortes e havia militância mais atuante.

\subsection{Os Leigos da Ação Católica Especializada}

As raízes das Comunidades Eclesiais de Base podem ser buscadas, também, na Ação Católica Especializada. Como já foi revelado, D. Fragoso tem uma passagem significativa na Ação Católica Operária e na Juventude Operária Católica, durante o período em que foi bispo auxiliar de $\mathrm{S}$. Luis do Maranhão. Sua ação em Crateús, segundo ele próprio e outros autores que analisam sua passagem por essa Diocese, foi marcada por uma visão de Igreja adquirida ao longo do seu período como coordenador da Juventude Operária Católica. Durante esse tempo, ele, que era oriundo de uma família de pequenos agricultores da Paraíba, conviveu com os operários, dialogou com os mesmos, a partir da realidade vivida por cada um no trabalho, na família e com os outros que compartilhavam a mesma situação. Era essa a proposta da Ação Católica especializada, atuar junto a segmentos específicos da sociedade civil, vivenciar seus problemas e discuti-los à luz do evangelho.

O método usado pela Ação Católica Especializada era o ver-julgar-agir. Esse método implicava olhar a realidade e olhá-la a partir dos envolvidos. Era um olhar também coletivo, portanto, com várias nuances que permitiam uma visão mais rica, mais multifacetada, mais complexa da realidade focada; depois, o julgar que implicava a tomada de posição, posicionar-se diante do real que também não era um posicionar-se individual, mas coletivo, fruto do diálogo entre as partes, entre os indivíduos que participavam desse coletivo. Eram posições diferentes, formulação de juízos também diferentes que se chocavam no diálogo e se conformavam na construção de uma visão mais 
ampla do real; por fim, o agir e o agir, como última parte desse método de apreciar a realidade, de acordo com os dois passos anteriores: tomada de posição e a partir dela atuar sobre o real com os outros, portanto politicamente.

Não é difícil verificar a relação dessa postura com aquela que depois será verificada nas Comunidades Eclesiais de Base. Ela se enriquece, pois nas CEBs estão presentes várias categorias de trabalhadores, vários segmentos da sociedade com experiências de vida diversas que fazem alargar o olhar dos seus membros. As Comunidades adotam o mesmo procedimento metodológico incorporando o método de Freire que confronta o participante com uma realidade mais ampla, pois foca o espaço de vida e trabalho dos segmentos populares contrapondo-os, a partir de sua própria práxis, aos segmentos dominantes que controlam os espaços de vida, de trabalho, de lazer a partir da fábrica, da terra e do Estado.

Diferente da Ação Católica é que a ação das CEBs não se faz apenas para fora da Igreja, não é apenas o resultado da ação da Igreja que procura diminuir os espaços da esquerda, evitar que o proselitismo comunista consiga adeptos entre os explorados, mas volta-se também para o interior da Igreja, exigindo desta uma ação mais condizente com o evangelho e aberta ao leigo como parte integrante da mesma. Sua ação não se resume a modificar as relações de produção capitalista tornando-as mais humanas, mas revolucioná-las, transformá-las radicalmente. O sonho que se constrói a partir das Comunidades Eclesiais de Base é a emergência de uma sociedade socialista sem empregados e empregadores. Uma sociedade, como se pode ver através da ação para dentro da Igreja, sem hierarquia, mas com um poder compartilhado, democrático, à semelhança das comunidades cristãs antigas. O modelo que move os cristãos é o modelo de sociedade constituído de muitas CEBs se autogovernando; mais que um modelo de sociedade laico é um modelo religioso e, tanto é verdade, que perdura a metodologia das CEBs nos movimentos sindicais dos segmentos populares contaminados por elas: a leitura do evangelho e à luz dele a leitura da realidade. 
Gostaria de poder aprofundar essa questão. Mais que um movimento laico, as CEBs se constituíram em um movimento religioso, um projeto social de Igreja ou um projeto de sociedade como Igreja, assentado na Igreja. No entanto, não é este o momento nem o espaço para tal discussão. Mas, as CEBs são herdeiras de um modo de ver a religião que vem das discussões e da necessidade de renovação que, por sua vez, vem da Ação Católica Especializada. Mesmo que as diferenças existam, elas não podem negar essa herança. A Ação Católica Especializada, principalmente a Juventude Universitária Católica e a Juventude Estudantil Católica, são promotoras de uma visão mais crítica que se construiu ao longo dos anos de 1950, influenciada pelo debate com a esquerda marxista e por religiosos franceses.

Para compreensão desse processo de construção dessa nova visão de Igreja, mais inserida no meio, mais engajada, as leituras de Gómez de Sousa (1984) e de Löwy (2000) são extremamente esclarecedoras. O primeiro autor faz uma análise do processo de desenvolvimento da Juventude Universitária Católica, da qual foi dirigente, mostrando como em função das disputas com outras correntes do movimento estudantil católico foram paulatinamente mudando sua prática política e radicalizando seu discurso. Mas toda essa caminhada se assentava sobre a prática religiosa e a reflexão teológica de padres franceses que viam o capitalismo não só a partir dos evangelhos, uma nova leitura dos evangelhos, como também numa aproximação com a teoria científica marxista. São as categorias econômicas de Marx apropriadas por eles que ajudam na compreensão do modo de produção capitalista e da impossibilidade de se superar as desigualdades gritantes entre as classes sociais.

Partindo do pressuposto que diante da pobreza e da miséria em que vivia parte significativa das populações trabalhadoras, principalmente aquela que vivia nos países chamados de periféricos, a Igreja propunha a necessidade de promover o homem, a promoção humana de que tanto se fala nos escritos da mesma, inclusive como uma forma de promover a paz social, 
evitar os conflitos entre as classes que conturbavam as sociedades. É precisamente esse trabalho de promoção humana que irá transformar a militância estudantil e seus assessores em críticos do capitalismo e exigir, ao mesmo tempo, mudanças na doutrina social da Igreja. Segundo o autor, na medida em que a compreensão dos jucistas se amplia e sua prática se radicaliza, radicalização que leva o movimento de JUC a entrar em choque com a hierarquia.

Os jovens 'enviados ao mundo', colocam à Igreja institucional questionamentos que muitas vezes a deixam perplexa e a encontram despreparada para uma resposta. O aparelho conceitual da teologia tradicional não está preparado para apreender a prática nova e seus problemas. As distinções (espiritual e temporal, humano e divino, relação horizontal entre os homens e vertical com Deus, etc.) rompem-se por uma ação que une toda a vida e penetra por todos os poros da realidade. (GÓMEZ DE SOUZA, 1984, P. 247)

Fica claro que os bispos não estavam preparados para a radicalização dos jovens, para sua ação no meio que, na visão dos bispos, segundo se depreende da análise de Gómez de Souza, dizia respeito à vivência na fé, viver em sociedade em conformidade com a doutrina católica, ser exemplo e influenciar aqueles ao seu redor para, como eles, viverem a fé e a doutrina. Não era o caso de atuar no meio, com a perspectiva de criticar a sociedade e suas estruturas, denunciar a exploração e contribuir para a construção de uma nova sociedade ou de compartilhar um projeto de mudança radical da sociedade juntamente com outras forças sociais laicas. A Igreja buscava com a Ação Católica Especializada atuar em determinados segmentos sociais onde forças de esquerda tinham presença significativa. Sua finalidade era barrar o desenvolvimento dessas forças e incorporar os segmentos sociais sobre os quais elas atuavam.

Mas ninguém escapa ileso do debate, do confronto que se afirma com a presença dessas forças políticas, muito menos quando o que está em discussão é a própria realidade, e nesse caso, a realidade de trabalhadores submetidos à exploração do capital no campo e na cidade, de jovens que não podem frequentar os bancos escolares e universitários, de toda uma 
população que não tem acesso à cultura ou aos meios culturais para expressar suas formas de fazer e pensar, aliás, fazer desqualificado pelas elites dominantes. Esse é o meio com o qual se defrontam os jucistas e que, no diálogo com outras correntes e com a sociedade, sentem-se tocados e questionam seu próprio lugar e o lugar da hierarquia católica. Gómez de Souza vai, através da análise dos encontros, mostrando o processo de construção desses jovens como agentes de transformação e a construção de uma compreensão da realidade a partir de um universo conceitual que se afina e afirma ao longo da sua ação política e social. O meio se estende à sociedade, a doutrina social da Igreja se transfigura na ação transformadora, na crítica à sociedade capitalista e na necessidade de superação da mesma. Incorporam os conceitos analíticos de Marx e o absorvem a partir de Lebret, Mounier e de outros religiosos franceses. Aliás, a influência francesa é confirmada por Gómez de Souza e por Löwy. Este último inclusive relata o impacto de Lebret na JUC da seguinte forma:

Economia e Humanismo' terá um impacto durável sobre o pensamento do bispo do Rio, D. Helder Câmara, que considerava Lebret como um verdadeiro profeta, e sobre intelectuais católicos conhecidos, como Alceu Amoroso Lima e Cândido Mendes. Entre os seus partidários estão os dominicanos - principalmente em S. Paulo - como Frei Benvenuto Santa Cruz, o principal colaborador brasileiro de Lebret, ou o teólogo e biblista Frei Gorgulho e os principais quadros da JUC desde o começo dos anos 50 (Plínio de Arruda Sampaio, Francisco Whitaker) até 1958/1960 (Luís Eduardo Wanderley e Vinicius Caldeira Brandt). Aos jovens jucistas propõe que saiam dos muros da universidade para pesquisar as condições de vida dos trabalhadores e dos favelados. (...) Lebret teve também um papel importante ao contribuir para 'desdiabolizar' o marxismo aos olhos de muitos católicos brasileiros. (LÖWY, 2000, p. 235)

O autor ainda irá acentuar o papel de Thomas Cardonel e de Jean-Yves Calvéz. Destaca a influência que esses religiosos exercem sobre a JUC brasileira, principalmente Cardonel. Sobre esse religioso dominicano ele dirá:

Poucos dominicanos que vieram ao Brasil tiveram tanto impacto sobre a esquerda católica quanto Thomas Cardonel. Sua breve permanência - de dezembro de 1959 ao final de 1961 - eletrizou a atmosfera e contribui para radicalizar os 
espíritos. Sua pregação de estilo profético sobre temas sobre o dinheiro e a pobreza, seus laços com os jovens da JUC fizeram-no entrar em conflito com a hierarquia brasileira, principalmente Dom Jaime de Barros Câmara, o bispo conservador do Rio. Charles Antoine, em sua história da igreja brasileira contemporânea, apresenta-o como um dos homens que marcaram o começo da nova década e contribuíram para a grande virada da juventude católica brasileira. (LÖWY, idem, p. 241)

A realidade com a qual se defrontavam, os embates que enfrentavam com as forças políticas que atuavam na universidade e a influência teórica dos padres franceses, são elementos que formam, ou mais do que formam, conscientizam os jovens jucistas brasileiros. É bom enfatizar que a influência francesa não é gratuita e não surge do nada, já é uma consequência da ação que os jucistas desenvolvem na sociedade, talvez uma consequência do método utilizado do ver-julgar-agir própria à Ação Católica. Esse método implicava em envolvimento com a realidade, conhecê-la, posicionar-se, implicava em estar aberto para a realidade ou meio, como era a linguagem da Igreja. Aprender com a realidade, dialogando com ela e com os demais, seus parceiros de JUC e com aliados que ao longo da caminhada construíam. A realidade brasileira, com os conflitos que emergiam no processo de modernização do campo e a industrialização era uma escola, pois exibia problemas, como o aumento das diferenças entre os segmentos sociais, como a ausência de estruturas que atendessem minimamente as necessidades que apareciam, principalmente para os segmentos dominados ou populares, com a expulsão do homem do campo e sua substituição por máquinas.

Não se pode esquecer que na década de 1950 e nos anos de 1960 o método de Paulo Freire já era utilizado em larga escala, tanto o programa de alfabetização de adultos quanto os círculos de leitura, ambos usados por militantes de esquerda e pelos movimentos da Igreja Católica; basta ver que o Movimento de Educação de Base, programa de alfabetização de adultos organizado pela Igreja em convênio com o estado, usava o método de alfabetização de Freire. Desse método, aproveitavam os estudantes universitários, a ênfase no diálogo, diálogo que se construía a partir da 
realidade e mediado por ela. À pedagogia de Paulo Freire somava-se ao método da Ação Católica ver-julgar-agir que não se esgotava na ação, mas nela continuava voltando ao começo, um começo que já era modificado pela ação inicial, ampliando cada vez mais a percepção da realidade e a qualidade da ação. Não se pode negar que o processo de construção da JUC e sua inserção nos movimentos e embates que se davam na sociedade eram uma prática educativa privilegiada, nesse trabalho de atuação e ativação política promovida por essa entidade e pelas demais que com ela disputavam ou se completavam; no processo de inserção política na sociedade aprendiam os militantes sobre a realidade dos segmentos populares, com os próprios segmentos populares e suas lutas, na ação concreta. Nesse processo de aprendizagem, essa aprendizagem voltava-se para eles, jovens oriundos dos segmentos médios da sociedade e sobre a entidade que Ihes dava sustentação, a Igreja Católica. Nesse voltar-se sobre si mesmo e sobre sua realidade questionavam a Igreja e a paralisia da mesma no que diz respeito às mudanças mais profundas na sociedade brasileira de então.

Emanuel de Kadt (2007), ao refletir sobre a Igreja católica no Brasil e sua inserção na sociedade, situa a Juventude Universitária Católica entre os católicos radicais e justifica essa introdução dos jucistas entre os radicais pela postura que esses tinham diante da realidade, não ficaram restritos ao espaço que thes fora conferido pela hierarquia como Ação Católica Especializada. Foram adiante, perceberam com sua ação e as injunções decorrentes dessa ação no meio, que a universidade era uma instituição social no contexto da sociedade de classes elitista e comprometida com a visão de desenvolvimento então prevalente, que era o desenvolvimento do capitalismo. Uma instituição que dificilmente poderia ser estendida ao conjunto da sociedade brasileira sem provocar mudanças substanciais no poder existente. Freire, em seu diálogo com Horton, lembra que no período em pauta, 1950/1960, a maioria da população brasileira não podia exercer o direito de escolher, através do voto, seus representantes. Não podia votar nem ser votado, por isso em Pernambuco, durante o governo Arraes, faz-se 
um esforço intenso para alfabetizar a população trabalhadora, alfabetizá-la e conscientizá-la a partir do método criado por ele.

Aqui, portanto, está outro caminho que conduzirá os estudantes para uma posição revolucionária mais generalizada, posição que os conduziu, católicos e não católicos, a engajar-se no âmbito da sociedade como um todo, para além do seu meio específico. As políticas estudantis, como veremos agora, fizeram a ponte entre a universidade e a sociedade. Mas, na medida em que crescia a convicção de que não se veriam grandes mudanças na universidade enquanto não houvesse transformações radicais na sociedade, os estudantes participavam mais intensamente e não apenas discutiam sobre a 'realidade brasileira'. Criaram ou aderiram a organizações que priorizavam atividades fora da universidade, que se engajavam em trabalhos políticos ou educacionais junto às massas, nas cidades ou no campo, como os Centros Populares de Cultura e a Ação Popular. (KADT, 2007, p. 94)

Todo esse envolvimento decorre exatamente da relação que mantêm com os demais grupos universitários e sociais que enxergam além da universidade. É claro que esse movimento da JUC não se faz sem percalços, vários atritos vão ocorrer com a hierarquia da Igreja Católica, principalmente com os bispos. Na medida em que, enquanto grupo organizado, penetra nas discussões nacionais suas posições vão chamar a atenção das elites dominantes que tinham na Igreja uma aliada. Essa visibilidade da JUC era mais acentuada por expressar uma visão de Igreja assentada em premissas que não atendiam aos interesses da elite católica posto que oriundas do marxismo. Sendo assim, a pressão da elite e da hierarquia aumenta e a JUC passa a ser denunciada nacionalmente como mais um grupo de esquerda que quer perturbar a vida nacional. Para Kadt:

A entrada maciça da JUC nas políticas estudantis nacionais colocou-a em contato mais próximo, do que tivera até então, com outros grupos de estudantes, inclusive os da esquerda laica, com quem passou a colaborar em escala crescente. Em 1962, houve somente um candidato para a presidência da UNE apoiado por todos os grupos majoritários, dos comunistas até a JUC. ... Seus pronunciamentos sobre a política nacional e incursões no campo político multiplicaramse; a JUC tornou-se manchete na imprensa nacional. (KADT, idem, p. 95) 
Nesse processo, a JUC vai construindo sua identidade e, a partir dela, vai estabelecendo os opositores, dentro e fora da Igreja, na sociedade maior. Com relação à Igreja, apropria-se da doutrina, para questionar a posição da hierarquia conservadora comprometida com os segmentos dominantes, fora da Igreja, percebe que o reino de Deus não é uma quimera a ser vivida após a morte, mas uma possibilidade no presente, afinal Cristo se compromete com os pobres em vida. Os jucistas preocupam-se, como cristãos, com a construção desse reino na terra, combatendo a miséria e suas causas, que identificam como naturalmente produzidas pelo modo de produção capitalista, como uma consequência da exploração do capital sobre o trabalho, nas relações de troca desiguais entre os países desenvolvidos e não desenvolvidos.

Nesse processo de construção de uma consciência social, os jovens da JUC contaram com o apoio dos seus assistentes que, como eles, acabaram por se comprometer com as lutas, apoiando-os, mas, ao mesmo tempo, tendo o cuidado de não romper em definitivo com a Igreja. Dentre os colaboradores, vários irão constituir o grupo de religiosos que, na América Latina, elaborará uma teologia mais comprometida com os pobres, a Teologia da Libertação, assentada sobre a realidade desse continente e nos princípios emanados pelo Vaticano II. São eles que com a Teologia da Libertação justificarão uma nova forma de ser Igreja: as Comunidades Eclesiais de Base que marcaram de forma profunda todo um período da nossa história política e social.

Os jovens jucistas e os seus assistentes em sua postura de compromisso com a sociedade brasileira encontravam apoio para sua ação mais independente da hierarquia católica na nova visão que emanava do Concílio Vaticano II. Kadt faz inclusive menção em nota de rodapé à autonomia adquirida pelos leigos em sua ação evangelizadora, lembrando que até o final dos anos de 1950 os leigos "recebiam formalmente um 'mandato' dos bispos para ação apostólica de cristianização" o que deixa de acontecer quando “(...) o Concílio Vaticano II, em meados de 1960, vai consagrar a teologia segundo a qual a missão apostólica já pertence 'naturalmente' aos 
leigos, em virtude do próprio batismo, e não necessita mandato da hierarquia." (KADT, p.104)

Mas, mesmo assim, os assistentes, como também os próprios jucistas acham mais conveniente criar um espaço próprio para sua ação política, que foi a Ação Popular, independente da Igreja e, consequentemente, das injunções da hierarquia. No entanto, vale frisar que sem a Ação Católica Especializada, sem as questões que levantaram sobre o papel da Igreja e dos leigos como membro dela e, por isso mesmo, também responsáveis por sua inserção na sociedade, dificilmente o foco sobre o papel do leigo, do leigo na Igreja e da Igreja na sociedade política, não haveria a virada que se deu nos anos sessenta e setenta do século XX. Essa virada, confirmada pelo Vaticano II, é uma consequência não apenas do papel exercido pelos jovens jucistas, ela decorre de uma série de comprometimentos que padres e leigos das diversas nações do chamado terceiro mundo vão assumindo diante da expansão capitalista e da modernização tecnológica e científica que daí decorre. Esse processo expansionista quebra as estruturas de produção tradicionais assentadas sobre relações estáveis entre os segmentos sociais então existentes. Gera a miséria, a migração, a instabilidade, as incertezas quanto ao futuro e a consciência de inutilidade entre os jovens. Nesse processo, a única instituição sobre a qual se apoiar é a própria Igreja. Nesse caso, pode-se dizer que não apenas os leigos e religiosos se dando conta dessa realidade de incertezas gerada pelo capitalismo procuram atuar de maneira diferente, mas que a sociedade como um todo, mais especificamente os que sofrem com o processo de modernização, procuram a Igreja e exigem dela um comportamento mais comprometido, mais ativo na resolução das questões que os afligem.

Comblin, ao apreciar o trabalho da Diocese de Crateús junto às Comunidades Eclesiais de Base levanta algumas observações pertinentes na relação da Igreja com os camponeses e desses com a Igreja. Dessas observações destaco uma que acredito pertinente para aquilo que venho colocando ao longo deste texto: 
Na situação atual, a religião é um dos últimos refúgios, talvez o último, em que as classes populares podem existir socialmente, exprimir a sua identidade e ter uma cultura própria. Nas áreas da vida social e pública elas são puro objeto de forças que não podem nem conhecer. Portanto é compreensível o grande desenvolvimento das religiões populares no Brasil de hoje. É a última resistência do povo para se defender de uma sociedade que esmaga totalmente e se desenvolve longe deles. Não se vislumbra mudança previsível dentro de prazos razoáveis. (COMBLIN, 1989, p. 9)

Ele escreveu esta análise por volta de 1971 depois de ter visitado a Diocese de Crateús e participado de encontros promovidos por aquela diocese com as lideranças das comunidades de base. Acredito que essa observação é pertinente, não apenas para os camponeses, e ele estava falando de uma Diocese que tinha a maior parte de seus fiéis na zona rural, mas também para os setores urbanos, na medida em que o processo de modernização do campo e o estímulo à grande propriedade rural monocultora era política oficial neste País, o que forçava os trabalhadores do campo a migrar para os centros urbanos, constituindo o grosso dos trabalhadores não especializados que ocupavam funções subalternas e moravam, na falta de espaços melhores, nas favelas do Rio e de S. Paulo.

É esse público que irá impressionar os jucistas e seus assistentes como também a religiosos estrangeiros que integravam a Igreja Católica no Brasil. A miséria dessa população, as condições de moradia e de trabalho a que estava submetida essa população exigia da Igreja uma opção e é essa opção que fazem os jucistas.

\subsection{O Movimento de Educação de Base e os Camponeses}

Anteriormente me referi à entrevista com o Padre Eliésio, vigário da paróquia de Ipueiras, cidade do sertão cearense pertencente à Diocese de Crateús, na qual fazendo uma retrospectiva da ação da Igreja, principalmente daquelas que resultaram no posterior aparecimento da Teologia da Libertação e das Comunidades Eclesiais de Base, ele indica que as 
mudanças que ocorreram na Igreja nos anos de 1950, 1960 e 1970, decorreram principalmente de três experiências vividas a partir da instituição e dos leigos: na primeira ele situa a Ação Católica Especializada; a segunda ele se refere à experiência vivida no Rio Grande do Norte, sob a orientação de D. Eugênio Sales, bispo de Natal, com, segundo ele, a criação de Comunidades, "mas a compreensão que ele, D. Eugênio, tinha das comunidades era de comunidades destinatárias de uma ação social da Igreja"; e por fim os padres que vieram da Europa, "formados na Europa, então começaram uma compreensão não só social, de pessoas destinatárias de uma ação social, mas sujeitos da própria Igreja, sujeitos da vida da Igreja." ${ }^{39}$

É interessante a fala desse padre por procurar compreender, de forma mais profunda, o fenômeno CEBs. Sua perspicácia vai adiante, procurando situar a Igreja do Nordeste dentro desse processo mais amplo, como a formação de leigos realizada no Maranhão para atender as demandas religiosas do interior sem padres; a experiência vivida por D. Helder Câmara em Pernambuco, ao veicular na Rádio Católica de Olinda um programa de cinco minutos, quando falava sobre um tema qualquer, interpretando-o de acordo com os evangelhos e solicitava que os ouvintes, em grupos formados a partir da vizinhança, após ouvirem a fala do bispo, discutissem aprofundando a temática. Eram ações inovadoras que envolviam os leigos numa reflexão mais aprofundada ao mesmo tempo, como diz o próprio Eliésio, em que passavam a ver a Igreja de modo diferente, não mais apenas como espaço dos padres e bispos, mas também como espaço dos leigos, eles passaram a se ver como Igreja e Igreja como prática, ação religiosa, e a partir do religioso, começaram a ver o social e o político.

No entanto, na sua entrevista, ele não se refere ao papel exercido pelo Movimento de Educação de Base - MEB. Esse movimento, criado por volta de 1961, tem em sua origem a experiência desenvolvida por D. Eugênio Sales, no Rio Grande do Norte. Segundo Kadt

\footnotetext{
${ }^{39}$ Entrevistas cedida ao autor em 2011.
} 


\begin{abstract}
A maioria dos documentos do MEB, incluindo-se os que tratam da história do movimento, começam seu relato a partir de um acordo entre o governo federal e a CNBB, no início de 1961, quando a CNBB concordou em expandir a experiência das escolas radiofônicas das dioceses de Natal e Aracaju para todas as áreas menos desenvolvidas do Brasil. A educação pelo rádio já vinha sendo feita havia alguns anos no caso da diocese de Natal, por exemplo, desde 1958. Dessa forma, era feito boa parte do programa de trabalho social do SAR, de grande alcance, instituído pelo bispo local, D. Eugênio Sales, sob sua supervisão direta. (KADT, ibidem, p. 149)
\end{abstract}

Interessante é como os pontos vão sendo ligados e como as preocupações vão se consolidando e possibilitando respostas. As forças sociais existentes na sociedade por volta dos anos de 1950 e 1960 eram muitas, basta ver que nessas duas décadas são levadas em consideração no espectro político nacional os camponeses e os trabalhadores urbanos, além dos estudantes e dos funcionários públicos, segmentos que emergem incorporando ideologias diversas, diversas formas de ver e sentir a sociedade, e que no confronto vão se consolidando alianças e antagonismos, construindo uma visão de mundo que paulatinamente discute e se contrapõe à visão de mundo hegemônica.

A percepção dessa conjuntura por parte de alguns políticos, principalmente aqueles que são identificados como populistas (lembro a forma positiva como Kadt define o populismo em oposição à forma como tradicionalmente os intelectuais de esquerda o veem), como Miguel Arraes, Jânio Quadros e João Goulart, é assentada na necessidade de incorporação dos segmentos populares na política. Sentem, todos eles, que se querem mudar a realidade brasileira, terão que mudar a maneira como a inserção popular ocorreu até aquele momento. Para consolidar o projeto populista, que, vale ressaltar, não é o mesmo para os três citados acima. Nem sei se poderia caracterizar Arraes como um populista, esses líderes políticos, em momentos diferentes e com diferentes perspectivas, aproximaram-se dos segmentos populares e da Igreja, segundo eles, uma força a considerar por sua influência e presença entre os segmentos populares. Preocupam-se com a educação, para alguns, restrita ao ler e escrever, pois somente assim poderiam de fato, 
através do voto, afirmarem-se no poder. No Brasil de então apenas os alfabetizados tinham o direito ao voto, apenas os alfabetizados eram cidadãos plenos.

No livro de Freire e Horton, já referida neste trabalho, os editores norteamericanos, na introdução, lembram a preocupação de Arraes com a alfabetização de adultos; acreditava 0 governador do estado de Pernambuco, o que era compartilhado em parte pelo próprio Freire, que a alfabetização em massa poderia modificar o perfil da política no Brasil. Por isso, convida Freire para participar de seu governo.

Em 1959, Miguel Arraes, um democrata nacionalista e radical, foi eleito prefeito de Recife. Na esperança de implementar mudanças fundamentais, ele compreendeu que primeiro teria de educar a população pobre rural que, embora constituindo a maioria da população do estado, não podia votar porque era, em sua maior parte, analfabeta. Arraes endossou a criação do Movimento Cultural Popular (MCP) de Recife, que levaria a cabo um programa de educação comunitária, alfabetização de adultos e desenvolvimento de uma consciência crítica no povo. A iniciativa ajudaria a mobilizar os trabalhadores rurais e urbanos para que exercessem seu poder político e Freire foi convidado a coordenar o projeto de educação de adultos. Seu primeiro passo foi desenvolver logo uma série de centros e círculos culturais que passaram a ser a base para a alfabetização de adultos. (FREIRE e HORTON, 2003, p. 28)

Mais adiante, o próprio Freire irá dizer:

As pessoas queriam e precisavam aprender a ler e a escrever, justamente a fim de ter mais possibilidade de serem elas mesmas. Isto é, as pessoas queriam ler e escrever naquele momento porque sabiam que estavam sendo impedidas de votar porque não podiam ler e escrever palavras. (FREIRE e HORTON, idem, p. 95)

Era o reconhecimento de uma necessidade em um momento em que as forças populares começavam a se tornar protagonistas, a pressionar por mudanças substanciais na sociedade e na relação entre sociedade e estado. Era um momento de mudanças e de emergência de lideranças mais comprometidas, mas também de lideranças ligadas a setores mais conservadores e em disputa com outros segmentos da própria burguesia. $\mathrm{O}$ 
voto era fundamental, portanto, para mudar a sociedade institucionalmente era necessário o voto e, claro, era necessário o controle sobre as forças que emergiam na sociedade.

Sendo assim, Jânio Quadros, quando em campanha presidencial no Nordeste, tomou conhecimento da experiência das escolas radiofônicas, solicitou que a Igreja Católica preparasse uma proposta para sua utilização nacionalmente.

Durante a campanha para as eleições presidenciais de 1960, em visita a Sergipe, Jânio Quadros conheceu o trabalho do sistema de escolas radiofônicas da diocese de Aracaju, cuja atividade básica era a de ensinar camponeses adultos a ler e escrever. Quadros ficou bem impressionado e, durante a visita a Aracaju encontrou-se com o arcebispo, D. José Távora, responsável pelas escolas radiofônicas. Durante aquele encontro, D Távora e Quadros discutiram a possibilidade da Igreja organizar este tipo de educação pelo rádio em maior escala, por todo o país. (KADT, 2007, p. 150)

A perspectiva da Igreja quanto à alfabetização era, em primeiro lugar, assegurar uma educação sedimentada em valores religiosos que impedissem a assimilação da crítica radical dos comunistas à sociedade capitalista liberal. Para ela, a educação tinha por finalidade a promoção humana, significando esta a absorção de valores assentados no trabalho familiar, na propriedade privada familiar, e a partir daí, como Marx no 18 Brumário, assegurar o modo de produção capitalista pelo aumento dos proprietários; esses zelosos de suas propriedades não cederiam à pregação coletivista e socialista da propriedade da terra. Alfabetizados, seria mais fácil a assimilação da doutrina da Igreja e, consequentemente, dos valores professados por ela e daí o controle da hierarquia sobre o rebanho.

É interessante lembrar que na Diocese do Crato iniciam as escolas radiofônicas a partir de 1959 e o objetivo proposto para as mesmas é a organização comunitária fomentando uma nova maneira de ser. Para a Diocese "não são apenas novos conhecimentos que se transmitem nem novas técnicas que se ensinam, mas uma nova visão do mundo que se impõe,... não é apenas um indivíduo que se instrui e se conscientiza, mas 
uma comunidade solidária..." (Fundação Pe. Ibiapina, 1981, P.13). Essa experiência da Diocese é construída em consonância com Natal, Fortaleza, e em outros contatos em que se treina o pessoal local sob perspectiva de uma Igreja educadora, voltada para a promoção do homem dentro e a partir dos valores cristãos então disseminados.

O exemplo de Padre Ibiapina é sempre lembrado pela Diocese do Crato. Vários opúsculos sobre a sua ação nos sertões nordestinos são escritos ou divulgados, mostrando que essa preocupação da Igreja não é de agora; Ibiapina, em sua prática pastoral, procurava estabelecer a paz nas comunidades rurais, organizar a vida produtiva e moral dos seus moradores, mostrar que o apoio da comunidade era fundamental para o crescimento de cada um em particular. No levantamento das carências das comunidades interioranas, Ibiapina estimulava a construção de barragens, cacimbas, cursos para capacitação de costureiras e donas de casa, estímulo à produção de meizinhas etc. E é esse roteiro de ações que a Fundação Pe. Ibiapina seguirá, agora apoiada por toda uma rede de educação assentada na doutrina cristã da promoção do homem em sua totalidade.

No Rio Grande do Norte, D. Eugênio Sales tinha conhecimento da ação de Ibiapina, de sua preocupação em moralizar dentro do espírito cristão da solidariedade e da piedade as comunidades rurais. Afinal, quando Ibiapina se volta para essa ação, sua preocupação é a construção de uma comunidade avessa às pregações messiânicas e estruturadas para as novas formas de produção e comércio. Ele, segundo Hoonaert (1984), ao realizar esse trabalho estava preocupado com a inserção dos pobres na sociedade, habilitando-os para o trabalho racional tendo em vista o desenvolvimento material da sociedade global. Esse autor ao analisar as populações interioranas o faz caracterizando-as como desclassificadas: há os classificados, os que contam no processo de produção e reprodução do capital, e os desclassificados que, mesmo não sendo contados, têm uma função no processo de expansão da fronteira agrícola no País. Os desclassificados são a população flutuante, à margem do processo de produção, mas necessária à reprodução do capital. Esse tipo de análise 
lembra Ranciére, na medida em que ele, ao analisar as sociedades capitalistas, as chamadas democracias ocidentais, o faz dividindo-a em duas partes: os que são contados e, portanto, ouvidos e incorporados, e os que não são contados, estão fora da sociedade como sujeitos políticos, mesmo que economicamente tenham seu lugar no processo de reprodução do capital.

Claro que ao pensar o desenvolvimento do capitalismo a partir da sociedade como um todo, faz com que Hoonaert enxergue a ação de Pe. Ibiapina como voltada para o trabalho, para o mundo do trabalho. Para ele, Ibiapina pretende educar a população do campo, racionalizar as atividades produtivas, aumentar a produtividade do trabalho para, com isso, diminuir a pobreza tão característica da época em que viveu Pe. Ibiapina. A modernização do país e, principalmente da região, era para ele um instrumento da pacificação do sertão nordestino. Não creio que sua intenção se situasse dentro de uma perspectiva que não fosse essa, não estava no horizonte de Ibiapina a luta de classes como uma consequência natural do desenvolvimento do capitalismo. Seu objetivo era incluir os desclassificados e, nas obras construídas nas comunidades, fixá-los no meio rural.

A análise de Comblin, acredito, vem completar a análise realizada por Hoornaert. Para ele:

Ibiapina não fez a teoria da sua ação. Não era homem de teoria, e sim de ação. Porém, de modo imprevisto e surpreendente, os seus dons de advogado e político foram recuperados e the serviram de maneira excelente. Ele tinha abandonado o mundo do direito e das leis. Ora, os seus dons apareceram imediatamente indispensáveis, pois se tratava de dar leis e estruturas a uma sociedade ainda flutuante... Evangelizar era reunir os desbravadores dispersos, os pobres desunidos para formarem um só povo. Nas suas peregrinações no interior, a maior preocupação de Ibiapina foi a de formar um povo, uma comunidade onde só existissem indivíduos isolados sem proteção e sem leis. (COMBLIN, 1984, p. 122)

Realmente não era difícil se espelhar em Padre Ibiapina quando se procurou dar densidade política e cultural apoiada na fé cristã aos camponeses. 
Ibiapina procurou sempre pacificar as populações rurais, criar as comunidades rurais reunindo o povo dentro de contextos estruturados capazes de assegurar as condições mínimas de vida. Populações dispersas, reunidas trabalhando coletivamente para o bem de todos, geridas por leis que não apenas ordenem, mas que ordenando juridicamente estabeleçam uma legalidade capaz de comportar as diferenças individuais dentro do coletivo, assegurando a existência desse como base para o viver melhor.

O Serviço de Assistência Rural, como a ideologia do desenvolvimento de comunidades, é instrumento, que nos anos cinquenta do século vinte, vai assegurar direitos, conformar dentro do espaço em que vivem os camponeses as condições de vida e trabalho para manutenção das famílias. Seu objetivo está em estruturar famílias dentro dos princípios cristão da solidariedade e da piedade. As escolas radiofônicas são elementos fundamentais nesse processo de divulgar os direitos, a fé e a caridade; são instrumentos de educação que divulgam os direitos e asseguram a manutenção das pessoas dentro da legalidade existente, evitando surpresas que conturbem a ordem social.

Assim, as escolas radiofônicas são instrumentos que permitem atingir um número significativo da população rural. Basta verificar a quantidade de emissoras católicas existentes em 1958, de acordo com Kadt, era de 32. Diante desse número de emissoras católicas e das possibilidades que se abriam, foi criada a Rede Nacional de Emissoras Católicas - RENEC. A intenção era criar um sistema de educação pelo rádio que atingisse as populações rurais, o que ocorreu por volta de 1960 e que depois serviu de modelo para a criação do MEB nacionalmente. É interessante destacar que o modelo que serviu de base para a criação do movimento de educação de base foi o de Natal, Rio Grande do Norte. Nesse Estado, a escola radiofônica vinha completar um trabalho que, iniciado no final dos anos de 1940, centrava suas ações na educação e na formação de comunidades, todas elas voltadas para procurar soluções para os problemas que vivia o homem do campo e que, segundo alguns, poderiam levá-lo à absorção da pregação comunista. Mudar essa situação era urgente. 
O rádio era um espaço privilegiado, pois atingia uma população que os padres, por serem poucos, não conseguiriam atingir, e ainda um espaço para o qual o leigo poderia ser fundamental. Primeiro, como técnicos, capazes de tocar os programas de educação desde a sua concepção até sua realização e emissão. Depois, os monitores, que eram pessoas da própria área onde se constituíam as escolas, pessoas que em função do programa logo se transformariam em lideranças comunitárias. A constituição da comunidade era outro ganho, como se sabe e se é repetido até a exaustão, as populações rurais eram dispersas nas áreas de latifúndio, reuni-los diariamente para os programas radiofônicos, criava laços entre eles que dificilmente poderiam ser rompidos. E os programas não ensinavam apenas a ler e escrever. Informavam sobre direitos, ministravam cursos agrícolas, sobre técnicas de cultivo, de higiene etc. Faziam treinamento com as lideranças e, nesse processo, exerciam sua influência sobre os monitores e sobre as populações beneficiadas. Não era desprezível o papel que o rádio tinha; era um instrumento que multiplicava a presença da Igreja nos recantos mais distantes. Gostaria, apenas à guisa de informação, lembrar que na região coberta pela Diocese do Crato, os camponeses chamavam os rádios de "rádios cativos", pois só sintonizavam a rádio da Diocese. Que significativo!

Com a criação do MEB, essa experiência é sistematizada, passa a contar com uma coordenação nacional e se submete às diretrizes da CNBB. Para se ter uma idéia da dimensão e do que representava o Movimento de Educação de Base, basta dizer que começou em 1961 com 2.687 rádios chegando, em dois anos, portanto em 1963, a 7.353 rádios. Segundo Kadt esse número, após o golpe de 1964, caiu em 1967 para 2.527 emissoras. Mas, mais significativo para a época era a quantidade de pessoas que eram atingidas pela educação radiofônica: em 1961 eram 38.734 alunos passando em 1963 para 111.066 alunos, portanto, quase triplicando em apenas três anos. Nesses jovens e adultos a Igreja incutia sua doutrina, sua maneira de ver a realidade e sua concepção de mundo, claro que não era uniforme, havia divergências e diferenças quanto à ideologia pregada por esses 
sistemas, mas diferenças que a CNBB, ao centralizar, evitava uniformizando os programas de educação. No entanto, ao constituir uma comissão de leigos para coordenar as atividades, muitos dos quais, como o próprio Kadt mostra, ligados a Ação Católica Especializada, principalmente a JUC, essa comissão acaba por dar uma dinâmica mais crítica aos programas influenciada que fora por suas histórias anteriores.

O MEB permite assim que a visão progressista oriunda da JUC, JEC e JOC, presente entre seus antigos militantes e agora técnicos do aparato do MEB, acabem por exercer influência sobre um montante muito mais significativo da população do que quando dos seus envolvimentos com a Ação Católica Especializada permitia.

Kadt irá dizer:

(...) No auge da atividade do movimento, havia, incluindo-se o quadro de secretários, o administrativo e o doméstico, mais de 50 pessoas trabalhando no Nacional; mais tarde esse número baixou para a metade. ... No Nacional, várias profissões estavam representadas, desde educação, sociologia e psicologia a direito e contabilidade. Alguns tinham diplomas universitários, outros estudavam enquanto trabalhavam. Cada um contribuía de acordo com sua perspectiva especializada para o funcionamento do Movimento e seu desenvolvimento ideológico que foi especialmente influenciado pelos vários estudantes e graduados em filosofia. ... No Nacional, também, havia muitos que, ainda estudantes, tinham sido ativos na política estudantil e na Ação Católica antes de vir para o MEB.

Não deixa de chamar a atenção que com a criação do Movimento de Educação de Base, o que vinha acontecendo nacionalmente de forma não sistemática ou pelo menos não articulada, era a preocupação da Igreja, através de seus bispos em suas dioceses particulares, com o avanço dos comunistas no campo, facilitada pelas condições de vida das populações rurais, acabou por tecer laços e vínculos que não se esperava. Na medida em que dioceses conservadoras como a de Natal, procuravam exercer de forma mais direta sua influência sobre as populações rurais, modificando dentro da ordem as condições de vida desses homens; na medida em que os movimentos católicos urbanos, através de sua ação sobre segmentos da população, para formar líderes que pudessem influir sobre a sociedade, 
evitando o radicalismo das esquerdas e a perturbação da "ordem social", como a Diocese do Rio de Janeiro; na medida em que dioceses se preocupavam com a formação de sindicatos de trabalhadores rurais para evitar a expansão das Ligas Camponesas, na realidade colocaram diante dos seus discípulos os temas, as questões e os problemas, que eram levantados pela esquerda a se tornaram, também, problemas, questões e temas daqueles que estavam sob sua asa. $O$ foco do debate e das disputas era a realidade do trabalhador e a realidade do trabalhador no capitalismo. Como enfrentá-la e como conviver com as diferenças ou com elas ser conivente se, ao se contrapor aos evangelhos, a realidade, da forma como se apresentava, era, por esses, questionada? A leitura de Marx demonstrava a impossibilidade da riqueza para todos, que o capitalismo, ao mesmo tempo, que gerava a riqueza de um lado, também gerava a pobreza do outro.

O Movimento de Educação de Base somente aprofunda essa percepção e a percepção dos trabalhadores passa a ser sistematizada e universalizada. Os próprios trabalhadores, diante dos debates levantados nos programas radiofônicos, vão se dando conta de que a realidade em que vivem não decorre da vontade divina, mas é fruto da ganância de poucos, se é possível colocar nesses termos num primeiro momento, porque depois se dão conta, ou vão se dando conta de que é próprio do sistema, nele só sobrevive quem explora ou se deixa explorar. A radicalização da percepção vai se expressando em cartilhas, em documentos, textos e na seleção das leituras, da mesma maneira que o método, que é a pedagogia de Freire, vai paulatinamente pondo a descoberto as relações de exploração, o jogo de interesses que envolve governos e empresários.

É interessante observar que nos anos cinquenta e sessenta do século XX a Igreja vai saindo de uma situação de envolvimento com as classes dominantes e médias da sociedade, para um envolvimento cada vez maior com os segmentos populares, saindo de sua posição de intelectual coletivo da classe dominante para a de intelectual coletivo da classe trabalhadora. Não é um partido que carrega consigo essa prerrogativa do intelectual 
coletivo no Brasil de então, mas a Igreja, é ela que sofre um processo de transformação interna que a torna cada vez mais necessária no processo de organização dos trabalhadores. Não está nesse processo embutida nenhuma decisão tomada pela hierarquia, é um processo de "conversão", como dizem alguns, que ocorre paulatinamente, na medida em que sai de dentro de si e se envolve nas questões sociais. A Igreja educa e se educa, transforma mentalidades e se transforma, abre para o leigo e o leigo a abre para o mundo. Os comunistas e marxistas vão deixando, na sua visão, de ser uma ameaça e acabam por se transformar, em algumas questões sociais e políticas, os aliados. Seus conflitos internos vão se agravando, mas sua presença na sociedade vai aumentando na medida em que radicaliza suas posições.

Teias vão se formando, da educação de base para o sindicato, da Ação Católica para a educação de base e, assim, vão construindo uma sociedade civil densa e tensa, que em parte é a base para as futuras comunidades eclesiais de base. O Movimento de Educação de Base, aglutinando pessoas ao derredor de um rádio, cativo, vai abrindo possibilidades, construindo laços de solidariedade, transformando indivíduos em coletivos políticos. Entendo que da mesma maneira se dá o trabalho sindical, iniciado pelo MEB em algumas regiões; ele vai também solidificando os laços entre iguais que não se viam sem as intermediações dos patrões. Coloco isso porque, fora as novenas comuns no campo e a festas religiosas, sobrava como espaço de reunião das populações rurais o terraço do proprietário, e nele cada indivíduo era um.

Bandeiras como a da Reforma Agrária, posta pelo movimento de organização sindical, ao serem veiculadas por representantes religiosos e leigos da Igreja, em programas de Rádios Educadoras dos diversos bispados, modificavam a forma de ver a terra, a propriedade da terra, mesmo que a Igreja aventasse a indenização das terras; mas a questão de que não é justo o latifúndio, como não é justo não se ter terra para plantar e dela viver com seus familiares, ter a terra é uma condição de ter vida, lutar pela vida é lutar pela terra. Focos como esse modificam a maneira de pensar 
e ser tanto da Igreja como dos camponeses e, nesse sentido, a Igreja é o grande educador. Por questões como essa é que Carlos Lacerda, governador do Rio de Janeiro nos anos sessenta do século passado, apreende ainda na gráfica a cartilha VIVER É LUTAR editada pelo MEB. E não é por outra coisa que o MEB vai diminuir suas ações e reformular suas práticas quando da instalação da ditadura militar em 1964. A manutenção financeira do MEB provinha, como já foi dito, de recursos oriundos do governo federal, reter os recursos é a forma como a ditadura restringe a ação do MEB.

As mudanças que ocorrem na Igreja nacionalmente repercutem em cada diocese, às vezes estimuladas pelo bispo diocesano, outras por padres que se afinam com as discussões inovadoras, que se renovam no debate com outras correntes em ação na sociedade civil, mas, ao que parece, em todos os lugares posições vão se afirmando, ações mais consequentes vão ocorrendo principalmente tendo como objetivo uma ação mais engajada, um envolvimento maior entre os segmentos populares. Os motivos desse engajamento podem se localizar no medo da expansão comunista, no afastamento dos segmentos populares, principalmente dos operários, na situação objetiva em que vivem as camadas populares, principalmente os camponeses submetidos aos interesses dos latifundiários e a modernização que os deixam à margem do processo produtivo, sem terra e sem trabalho para suprir as necessidades familiares. Não se pode acreditar, como fazem alguns, que o motivo do engajamento social e político de religiosos e leigos tenha sido apenas o medo dos comunistas e a possibilidade de perda de influência da Igreja na sociedade como um todo, não se pode achar que a diminuição do poder da Igreja tenha sido o principal motivo desse processo de renovação e engajamento social e político dos membros da Igreja, mesmo daqueles com posição hierárquica mais significativa, como era o caso dos bispos. Assumir essa interpretação é desconhecer, ou ignorar, a força que a mensagem fundadora tinha sobre os religiosos e leigos. Seria 
crê que a hierarquia era composta por sujeitos dotados, em sua maioria, de uma racionalidade fria, insensíveis aos princípios do próprio cristianismo ${ }^{40}$.

Martins (idem), como me referi acima, faz uma análise mais crítica e mais nuançada da inserção dos bispos e religiosos nos meios populares. Para ele, a realidade com a qual se confrontam padres e bispos estrangeiros no Brasil, faz com que eles se comprometam com uma Igreja mais engajada. $O$ autor vai ainda mais longe ao afirmar que não se dá entre eles nenhuma conversão, nenhum deles, seria mais correto dizer a maioria, passa a ter da Igreja uma visão mais progressista. O que ocorre é que a realidade social no Brasil os sensibiliza e, movidos pela caridade, mobilizam-se para mudar essa realidade. No entanto, com alguns padres e leigos ocorre realmente uma conversão, ou a origem dos mesmos já indicava uma postura mais crítica do real, fazendo-os se comprometerem com uma Igreja "encarnada" nos meios populares. Em Crateús, antes da chegada de D. Fragoso, portanto, ainda quando essa cidade era vinculada à Diocese de Sobral, já haviam ações comprometidas com uma Igreja solidária e parceira, uma Igreja voltada para uma ação junto às camadas mais pobres. Não diria que a sua ação fosse motivada pela ameaça comunista, apesar da presença comunista na Diocese. É mais pertinente afirmar que essa ação já estivesse conformada com o Concílio Vaticano II e com os novos ares da Ação Católica Especializada, na medida em que alguns grupos de jovens teriam sido organizados a partir da Juventude Estudantil Católica - JEC. O compromisso com os mais pobres, segundo alguns depoentes, partia da sensibilidade de um único padre: o Pe. Irismar.

Esse padre, portanto, teria organizado grupos de jovens em Crateús, jovens de classe média, para desenvolver trabalho de organização dos mais pobres por moradia, serviços de saúde e educação. A forma de trabalho do Pe.

\footnotetext{
${ }^{40}$ Em Crateús não havia medo da presença comunista. Pelo contrário, como é citado em entrevista por Eliésio e Machado a presença de comunistas na ação reformadora em Ipueira, na matriz de S. Gonçalo, é um prova disso. Da mesma maneira, Mesters se refere aos comunistas que participam das reuniões de avaliação e planejamento da Diocese, isso nos anos de 1970 e 1971, também em Crateús. Com relação aos anos de 1950 são divulgados no Brasil escritos dos padres franceses que usam, na análise da realidade, conceitos marxistas, esse fato é lembrado por Löwy em seu livro "A guerra dos deuses".
} 
Irismar se assemelhava ao desenvolvido pela Ação Católica Especializada tendo criado, inclusive, um grupo de JEC. Portanto:

Havia em Crateús e sob a liderança do Pe. Irismar, alguns movimentos assumidos por jovens e adultos, trabalhadores e operários, alguns destes despontavam com muita energia a serviço de uma ação considerada libertadora que partia da Ação/Reflexão/Ação (depoimento de Leinad no caderno 25 anos de Caminhada, no 14)

Esse trabalho anterior, sobre o qual se assentaria, mesmo que não relevado suficientemente na história da Diocese de Crateús, foi, segundo reconhecimento do autor acima citado, "... uma forte sintonia com a linha 'popular e libertadora', que representava o pensamento de D. Fragoso e seria o foco de ação da Diocese" (caderno 14, p. 09). Além da existência da JEC com toda a sua metodologia do ver/julgar/agir, outras formas de ação foram encontradas que revelavam uma base sólida para a ação de Fragoso. Dentre as iniciativas que encontrou quando assumiu a Diocese de Crateús estavam: Casa da Juventude Betânia, criada em 1958/59; as Luízas de Marilac, que reuniam os jovens mais atuantes e comprometidos da Casa da Juventude Betânia para uma ação nos bairros; as sociedades de Bairro; e as Sociedades Habitacionais, que tinham como atividade os mutirões habitacionais, ou seja, a construção e melhoria das casas dos segmentos populares que viviam nos arredores da cidade de Crateús.

São iniciativas que estimulam a ação e através dela a percepção das desigualdades. São ações que possibilitam a organização da sociedade e principalmente a despertam para as contradições sociais que não são naturais, mas fruto de um modo de produção que alija e marginaliza os segmentos populares. É interessante frisar que inicialmente esses jovens oriundos dos movimentos citados acima são depois aproveitados para assumir trabalhos e coordenações na ação da Diocese. $O$ autor do caderno 14, Leinad, assume a coordenação da Cáritas Diocesana e Antonia Vasconcelos, também oriunda da JEC assistida pelo Pe. Irismar, assume a coordenação do MEB - Crateús. Dessa última reproduzo seu depoimento transcrito no caderno 12 da Diocese de Crateús: 
Tudo começara antes quando através da participação na JEC, sob a liderança do Pe. Irismar, me iniciara no processo de reflexão sobre o momento histórico do País, sobre a realidade à minha volta e minha responsabilidade sobre esse contexto. (Caderno no 12, p. 41)

Portanto, deve-se considerar que a ação de D. Fragoso voltada para uma Igreja renovada, comprometida e engajada no social encontrou uma base sobre a qual se assentam. Afinal, nenhuma ação teria sucesso, ou repercussão, em tão pouco tempo se não houvesse elementos sobre os quais e com os quais ela pudesse desenvolver-se. Por outro lado, deve-se ressaltar que a Ação Católica Especializada deitou raízes em recantos mais inesperados, no caso em pleno sertão cearense, fincando raízes profundas e modificando de maneira radical o ser Igreja. Isso só foi possível pela existência de canais a partir dos quais suas concepções de lgreja e de sociedade puderam ser disseminadas. Um desses canais foi o movimento estudantil $^{41}$, outro, as seções estaduais da Ação Católica Especializada, os religiosos comprometidos com uma visão de Igreja mais encarnada, estudantes que do interior se dirigiam às capitais para continuar seus estudos e que não perdiam o vínculo com suas cidades natais, retornando embebidos de uma nova concepção de Igreja etc.

Não se pode esquecer que a ideologia do desenvolvimento de comunidade, através da ação da ANCAR, fez-se presente em Crateús e cidades próximas. A ANCAR desenvolvia um trabalho de organização comunitária, principalmente no campo, que possibilitava o encontro de trabalhadores para pensar sua realidade e as saídas possíveis dos estrangulamentos socioeconômicos que viviam. A situação da terra, as relações de trabalho, os diversos clubes, associações de produtores rurais, as condições de saúde e educação, precárias no campo, eram questões que eram postas e que de

\footnotetext{
41 “A JEC estruturou-se em Crateús, antes da chegada de D. Fragoso. VER - JULGAR - AGIR era a metodologia do nosso trabalho. (...)Participava da UNE (União Nacional dos Estudantes) e das concorridas eleições dos grêmios nos Colégios. Para protestar contra a morte de Edson Luís, um estudante assassinado pelos militares, a JEC de Crateús fez uma passeata, onde vários militantes fazem discursos." (Vinte Anos de Caminhada, CAD. 10, org. Ana Vigarani, 1989, p. 6)
} 
alguma maneira sedimentava uma percepção da realidade e de suas contradições entre os camponeses e técnicos.

No depoimento, já citado, de Antonia Vasconcelos Verdésio, a ANCAR é citada como uma parceira no trabalho desenvolvido pelo Movimento de Educação de Base da Diocese de Crateús. Da mesma maneira vemos na recuperação da história do MEB apresentada no Caderno Diocesano, 25 anos de Caminhada, № 12, várias citações da ANCAR como parceira no trabalho desenvolvido pela Diocese junto às comunidades rurais. Partindo do pressuposto que as populações rurais eram, até os anos cinquenta do século passado, rarefeitas, dispersas ${ }^{42}$ e que somente se encontravam nas festas religiosas e nas entronizações dos santos protetores das famílias, a organização das comunidades, ou a organização em associações e clubes promovidos pela ANCAR, tinham, pelo menos, o mérito de ao reuni-los possibilitar o diálogo sobre a realidade de cada um e de todos. A elaboração de projetos, a discussão sobre os mesmos e sua necessidade, a reivindicação de soluções para os problemas que viviam pode ter despertado os rurícolas, colocando-os em sintonia com as idéias e ideais posteriormente vinculados na ação da Diocese local.

[...] O trabalho da Cáritas fecundou dentro desse princípio em muitas das comunidades por ela animadas e apoiadas e, sobretudo, onde o trabalho era mais integrado com a ANCAR, o MEB e o sindicato. Fazíamos sistematicamente visitas às comunidades, utilizávamos a metodologia de Paulo Freire no que se refere à leitura da realidade e as reuniões eram um verdadeiro círculo de cultura, havia muitas situações reveladoras, verdadeiras descobertas de potencialidades. (LEINARD. 1989, p. 16)

\footnotetext{
${ }^{42}$ Facó irá dizer: "[...] Cria-se no Nordeste uma espécie de nomadismo permanente, que as secas só fazem aumentar e dar características mais trágicas. É então que se juntam, ante o flagelo, reúnem-se nos caminhos para as longas jornadas em busca de pão e água. Jamais haviam tido laços estreitos de solidariedade, isolados em choupanas perdidas nos ermos, a enormes distancias umas das outras, sem formarem ao menos qualquer simulacro de aldeia. A seca expulsa-os e congrega-os" p. 28. Mais adiante ainda dirá o autor de Cangaceiros e Fanáticos: "A vida isolada que viviam, perdidos nos ermos, incutia-lhes um individualismo estreito até mesmo no martírio. Não tinham senso de unidade, a não ser ocasionalmente, em momentos passageiros. A propriedade latifundiária semifeudal os havia dispersados. Seu único momento congregador só podiam ser as seitas semibárbaras que abraçavam, como uma réplica, à religião dominante.” P. 43
} 
Da mesma maneira, a Cáritas teve um papel fundamental na organização das comunidades rurais, posteriormente criticado por sua vinculação aos interesses imperialistas norte-americanos, crítica que D. Fragoso faz no seu livro O Rosto de Uma Igreja. Diz ele, num primeiro momento:

Decidimos então iniciar alguma ação social modesta. Começamos pela Cáritas, em fins de 1964 e começo de 1965. O escritório diocesano de Crateús estava filiado à Caritas Nacional. Recebia os gêneros que vinham dos Estados Unidos e tentava aplicá-los segundo os critérios pedagógicos do desenvolvimento comunitário.

Os gêneros eram excedentes agrícolas da produção dos Estados Unidos... Desse modo, os Estados Unidos chegavam a criar de si mesmos uma imagem simpática e generosa, provocavam a subida do preço da produção interna e continuavam a sustentar e fortalecer os mecanismos de concentração das matérias-primas, das tecnologias, dos centros de decisão econômica e política. $O$ povo mais consciente dizia:'Dão com uma mão e tiram com as duas.'

Nós que recebíamos, nos acostumávamos a ficar de mãos estendidas, como mendigos. Vínhamos de mais de quatrocentos anos de dependência. Éramos tentados a esquecer que 'o homem cresce quando dá a mão e não quando recebe. (1982, p. 24)

Mas, mais adiante, reconhece que sem a ajuda inicial da Cáritas o trabalho de organização comunitário seria difícil: "A cáritas foi, durante três a quatro anos, na Diocese, instrumento de ativação comunitária e de experiência coletivas dos trabalhadores." (p. 25)

A postura de D. Fragoso deixou algumas mágoas, principalmente entre os membros da equipe que realizava o trabalho comunitário a partir da ajuda da Cáritas. No caderno diocesano, 25 anos de caminhada, Leinad afirma inicialmente que "(...) Não é fácil escrever sobre isso (...) Cáritas é careta! (...) é leite em pó (...) é, também, imperialismo!" (Caderno no 14. P. 04). Em sua análise posterior levanta a importância dessa entidade da Igreja Católica como fundamental para o início do trabalho que posteriormente ganha repercussão nacional e internacional: 0 trabalho de Comunidades Eclesiais de Base. Os autores sabem e têm conhecimento de que essa ajuda vinda dos Estados Unidos era paliativa e procurava, antes de tudo, esconder as condições de exploração em que viviam os povos do terceiro mundo 
submetidos aos interesses imperialistas de grupos industriais e financeiros do primeiro mundo, tinham conhecimento de que se pretendia, com a ajuda, torná-los simpáticos diante dos povos explorados e mostrar que se havia miséria, essa decorria de condições objetivas próprias dos países subdesenvolvidos, não era uma consequência natural do desenvolvimento capitalista. Essa visão crítica eles, os autores, detinham, mas acreditavam que através dos alimentos era possível reunir os camponeses e discutir com eles a situação de vida a que estavam submetidos. Como D. Fragoso, sabiam que a falta dos alimentos, e ela um dia acabaria, poderia ter como resultado o retorno ao ponto inicial, afinal muito deles continuavam a vir para os encontros e reuniões promovidas pela equipe em função unicamente dos alimentos. Mas, era uma brecha que se abria e a equipe tinha a capacidade crítica para saber dos perigos que essa ajuda norte-americana poderia suscitar, mas acreditavam estar preparados para isso.

Essa é também a visão de Boff (1989). Para ele, não é a origem do que se recebe ou porque se recebe que é em si o mal, mas a maneira como se trabalha a partir do que se recebe, se há senso crítico, se se usa a ajuda norte-americana para discutir as motivações dessa ajuda e as relações que são estabelecidas a partir dela, não há mal na resposta, sendo assim, por que romper com uma ajuda que era importante a organização do povo de Crateús. Reproduzo Boff a seguir que com mais clareza levanta a questão:

(...). 'Igreja Popular', 'Igreja dos Pobres', Igreja Pobre'.

No retiro emergiu essa questão - a de uma Igreja fraca e pobre, mas que, por lucidez, se sente necessitada de recursos para desenvolver sua missão libertadora. Está claro: ninguém quer uma Igreja rica e instalada (embora por 'causa do reino'), nem de uma Igreja Kenótica, pauperista, miserável.

No seu 'Pequeno Retrato de Igreja Diocesana' $(5, b)$ diz D. Fragoso naquele seu estilo talhado com facão, e cortante: 'As doações são muletas para aleijados. Quem é aleijado e quer andar tem precisão de muletas. Mas quem pode andar com seus pés, deve JOGAR FORA AS MULETAS'.

É uma questão difícil que deve ser aprofundada coletivamente. Aqui é apenas levantada.

Em termos práticos, melhor, pragmáticos, o TER recebe sua qualificação do OBJETIVO e da FORMA como é usado. Se é usado com a participação do povo e para sua libertação, isso 
respeita o evangelho e pode inclusive se impor concretamente.

Agora, uma atitude de despojamento de recursos disponíveis pode se justificar como recurso pedagógico (não se acostumar a receber e a depender disso) e como testemunho evangélico (para evidenciar que o reino de Deus não consiste nos recurso, mas na força do Espírito).

Mas quanto a isso também há objeções. Contudo, se é a Igreja local que toma coletivamente tal opção, esta se torna praticamente inquestionável. (Cad. Fazendo a nossa história, Testemunho de amigos, p. 25)

De qualquer maneira, não se pode negar que a Cáritas teve um papel fundamental na organização das comunidades rurais. Da mesma maneira o Movimento de Educação de Base - MEB, em Crateús, foi fundamental no processo de organização e consolidação das comunidades. Através dele são agrupadas as populações rurais como também o estavam sendo pelo trabalho da Cáritas; constituir comunidades no campo, reunir pessoas, colocá-las frente a frente, iniciar diálogos, fazê-las perceber a sua situação de trabalhadores sem terra e sem direitos trabalhistas já que estes não alcançavam o homem do campo, esse, me parece, era o grande objetivo de D. Fragoso. Ensinar e aprender, revelar a todos a questão do campo, refletir sobre ela, buscar desvelá-la, fazer emergir as contradições que estavam por trás dessa realidade, forjar lideranças e o MEB com seus coordenadores e principalmente seus monitores, todo esse processo foi uma escola fundamental para o aparecimento de lideranças, esse era o objetivo. Para tanto, apropria-se das experiências dos outros, a aproximação com a ANCAR era exemplo, apropria-se do método de Paulo Freire, aprender através de apreensão da realidade e mediada por ela, da metodologia a Ação Católica do ver-julga-agir, eram elementos fundamentais para criar os laços necessários á construção de um sujeito coletivo capaz de levar avante às mudanças necessárias a promoção do homem integral.

Não poderia deixar de destacar que a organização do MEB, em Crateús, ocorre no ano de 1965, já em plena ditadura militar, mas a ação do MEB se faz a partir da colaboração do Batalhão do Exército Brasileiro localizado nessa cidade, com a colaboração dos governos municipais e estadual em consonância com a ideologia do desenvolvimento de comunidades. Assim 
O MEB/Crateús pretendia mobilizar os espaços no governo e na sociedade para melhorar a qualidade de vida dos segmentos mais pobres da população.

Tinha como proposta a libertação do homem do meio rural, especialmente do mais marginalizado no processo social.

Acreditava que o homem seria capaz de assumir consciente e solidariamente o seu crescimento. Sendo que essa libertação só seria possível através da educação das pessoas em suas comunidades. (SOUZA, Francisca Françuita de,.25 anos de Caminhada, CAD. 12, 1996, p. 12)

Mais adiante a autora desse caderno irá dizer:

A equipe responsável pela experiência na comunidade de Betânia era constituída de agrônomos da Secretaria de Agricultura, extensionistas da ANCAR, educadores do MEB/Crateús e da Cáritas, e representantes da diocese e dos moradores. (idem, p. 19)

O trabalho na comunidade de Betânia era de organização da produção em cooperativa. As terras pertenciam à Diocese de Crateús e nela se procura vivenciar uma proposta de produção familiar voltada para o suprimento das necessidades das famílias lá assentadas. Como ficou claro, era evidente a ideologia do desenvolvimento de comunidades que passava pela presença da ANCAR e da própria Igreja, já que esta, desde o início dos anos de 1950, estava envolvida com os convênios entre o Brasil e os Estados Unidos, como bem esclareceu Ammann (idem). Era um trabalho de promoção humana: gerar condições para a produção agrícola e para a manutenção das famílias rurais que estavam sendo atingidas pelo processo de expulsão do campo em decorrência da modernização da produção agrícola. No entanto, para D. Fragoso, era a possibilidade de consolidar comunidades que pudessem perceber que através de sua organização poderiam superar as dificuldades em que viviam e, com isso, se tornarem autônomas, capazes de lutar por direitos que thes assegurassem a plena cidadania.

Destaco que o trabalho do MEB em Crateús se desenvolve, num primeiro momento, de forma independente e somente depois se incorpora ao MEB estadual e nacional. Nesse trabalho foi utilizado o rádio; a equipe de coordenação do MEB/Crateús constituía turmas que eram assessoradas por 
monitores formados pela própria equipe. Os membros da equipe participaram de treinamento no MEB estadual para se adaptarem à metodologia do programa. Os monitores ou eram líderes naturais ou se transformavam em líderes pelo trabalho que realizavam, trabalho que era de educação, ensinar a ler e escrever adotando o método de Paulo Freire com a preocupação centrada na conscientização, na introdução de culturas alimentares mais ricas, em tecnologias que racionalizassem o trabalho ao mesmo tempo que possibilitasse maior produtividade. Os programas radiofônicos semanais:

(...) tinham por finalidade animar os grupos nas comunidades para um trabalho organizado, estimular os animadores para uma ação prática e grupal, falando dos trabalhos já desenvolvidos nas comunidades, levantando problemas e tentando descobrir saídas. (LEINAD, 25 ANOS DE CAMINHADA,CAD 14, 1997, p. 29)

Com esse trabalho, a presença da Igreja de Crateús era intensa no meio rural, mobilizando, discutindo, educando, conscientizando. Voltada mais para as comunidades sociológicas, discutindo as carências existentes nessas comunidades tais como escola, posto de saúde, do que para as comunidades religiosas, estas somente se constituíram após a adoção da Bíblia como história exemplar a indicar os caminhos para a libertação. Não se pode negar que esse trabalho comunitário foi o chão para a construção das comunidades eclesiais de base, criou laços, tornou a presença da lgreja constante na vida de cada um incorporando cada vez mais o leigo nas atividades religiosas. Uma Igreja que elegia o pobre como o foco de seu apostolado, mergulhava na religiosidade dos segmentos populares, uma religiosidade que se faz ou se fazia longe dos padres, na convivência dos iguais na fé.

É interessante o que diz uma das primeiras coordenadoras do MEB de Crateús, ciente das parcerias assumidas com o Estado. Diz ela:

Toda essa ação resultava em comunidades mobilizadas, líderes treinados, grupos de agricultores e mulheres organizados fazendo frente aos problemas comunitários, 
alguns deles criando ou associando-se aos sindicatos. Um universo, amplo talvez, mais ainda pequeno para o tamanho da totalidade regional. $O$ nascimento desses pequenos núcleos parecia pouco significar na imensidão do nosso país, continental. Duas décadas depois, quando a abertura democrática pode vir à tona, observou-se que uma rede imensa de comunidades de base estava articulada e lhe dava sustentação. Nesse momento pode-se compreender que cada pessoa, cada povoado conscientizado naqueles tempos longínquos (...) teve seu papel no processo da conquista da democracia no nosso país. (Francisca Verdésio em depoimento presente no CAD. 12, 25 Anos de Caminhada. P. 45)

A inserção da Igreja no processo de formação e organização da classe trabalhadora não foi intencional num primeiro momento. Os religiosos, os leigos e muito menos a hierarquia, pretendiam gestar, ou tornar claro aos trabalhadores do campo sua condição de classe social, diferente dos latifundiários e dos burgueses e por estes explorados. Para Marx, no seu livro "O 18 Brumário", o campesinato não constituía uma classe social, perdidos nas grandes extensões do campo, sem conseguir formular demandas conjuntas e se colocar em oposição aos grandes proprietários de terra. Afinal, se há objetivamente a classe social caracterizada e definida por sua localização nas relações de produção, ela, ao mesmo tempo, somente se concretiza como tal na medida em que se constituísse em classe para si, na medida em que se colocasse em oposição àquele que a explora. O que não era o caso dos camponeses, na França, onde a terra já havia sido distribuída e o campesinato, diferente dos trabalhadores urbanos, se constituía como pequenos proprietários com interesses que eram definidos a partir das necessidades familiares particulares. Segundo Marx:

Os pequenos camponeses constituíam uma imensa massa, cujos membros vivem em condições semelhantes, mas sem estabelecerem relações multiformes entre si. Seu modo de produção os isola uns dos outros, em vez de criar entre eles um intercâmbio mútuo. ... Seu campo de produção, a pequena propriedade, não permite qualquer divisão do trabalho para o cultivo, nenhuma aplicação de métodos científicos e, portanto, nenhuma diversidade de desenvolvimento, nenhuma variedade de talento, nenhuma riqueza de relações sociais. Cada família camponesa é quase autosuficiente; ela própria produz inteiramente a maior parte do que consome, adquirindo assim os meios de subsistência mais através de trocas com a natureza do que do intercâmbio com a 
sociedade. Uma pequena propriedade, um camponês e sua família; ao lado deles outra pequena propriedade, outro camponês, outra família. Algumas dezenas deles constituem uma aldeia e algumas dezenas de aldeias constituem um departamento. A grande massa da nação francesa é, assim, formada pela simples adição de grandezas homólogas, da mesma maneira porque batatas em um saco constituem um saco de batatas. (MARX, 1976, p. 277)

No Brasil há uma segmentação muito grande da população rural. Se há pequenos proprietários, há, por outro lado, os assalariados temporários e permanentes, principalmente nas zonas produtoras de café e de cana-deaçúcar, os moradores e muitas outras formas de parceria que estabeleciam relações de produção mais ou menos favoráveis à produção e reprodução do capital agrário. Sendo assim, trazer para a nossa realidade essa análise que Marx fez sobre a França do século XIX pode ser tomado como inapropriada. Mas, considerando, como o faz Facó (1980) e Martins (1995), que a grande maioria dos pequenos produtores rurais por volta dos anos de 1950/60 era de moradores, trabalhadores que viviam nas grandes propriedades em áreas cedidas pelo latifúndio onde cultivavam sua agricultura de subsistência. Sua moradia era a garantia de mão de obra para as culturas exploradas pelo latifúndio. Mão de obra barata, pois a agricultura de subsistência, fruto do trabalho familiar nas áreas cedidas pelo proprietário, assegurava a reprodução do trabalhador. Era, principalmente, em função da atividade como morador, que se produzia e reproduzia o trabalhador do campo sem grandes custos para o capital agrário. Dessa forma, constituíam-se em pequenos produtores rurais assemelhados ao campesinato francês do século XIX, por se constituir, na maior parte do tempo, em produtor familiar.

Há diferenças, claro, mas as semelhanças permitem o uso teórico de Marx, até porque os moradores se localizam em áreas dispersas nas grandes propriedades, sem contatos uns com os outros, a não ser mediados pelos proprietários ou pelas atividades coletivas que assumiam nos períodos necessários a grande produção, nas festas religiosas populares, como na entronização dos santos e das renovações. Não havia o que se podia chamar de comunidades; a realidade de então não permitia essa 
denominação. Somente com a ação da Igreja e com a ideologia do desenvolvimento de comunidades vão se constituir como tal. Mesmo aqui fica difícil se estabelecer um padrão: até que ponto o desenvolvimento de comunidades poderia constituir comunidades em área de moradia? Ele não seria mais apropriado para as áreas de pequenas propriedades rurais? $\mathrm{E}$ nas áreas de assalariamento puro?

Analisamos, anteriormente, a forma como se constituíram as comunidades ${ }^{43}$ e como elas se constituíram negando a classe. Assim, a Igreja nega, em sua ação inicial, a oposição de interesses e os conflitos que são próprios ao modo de produção capitalista.

Mesmo quando parte do campesinato, expulso das terras do latifúndio onde conseguiam se reproduzir através da moradia e passavam a viver nos limites do latifúndio, a sua realidade, como classe, é escamoteada pela cooperação oriunda do desenvolvimento de comunidades.

Continuando a leitura de Marx verifico que o mesmo avança em sua análise da realidade campesina e revela:

Na medida em que milhões de famílias camponesa vivem em condições econômicas que as separam umas das outras e opõem o seu modo de vida, os seus interesses e sua cultura aos das outras classes da sociedade, estes milhões constituem uma classe. Mas na medida em que existe entre os pequenos camponeses apenas uma ligação local e em que a similitude de seus interesses não cria entre eles comunidade alguma, ligação nacional alguma, nem organização política, nessa medida não constituem uma classe. São, consequentemente incapazes de fazer valer seus interesses de classe em seu próprio nome, quer através de um parlamento, quer através de uma convenção. Não podem representar-se, têm que ser representados. Seu representante tem, ao mesmo tempo, que aparecer como seu senhor, como autoridade sobre eles, como um poder governamental ilimitado que os protegem das demais classes e que do alto

\footnotetext{
43 É necessário lembrar que as comunidades são constituídas, a partir da leitura de Facó, quando o homem do campo se agrega nas comunidades chamadas de messiânicas, quando fugiam do latifúndio em função de algum desastre natural. Ou, como bem o colocou Ammann, com a ideologia do desenvolvimento de comunidades, quando as cidades rurais, em sua maioria, eram consideradas comunidades, indiferenciadas já que todos tinham seu destino ligado ao seu desenvolvimento.
} 
Ihes manda o sol e a chuva. A influência política dos pequenos camponeses, portanto, encontra sua expressão final no fato de que o poder executivo submete ao seu domínio a sociedade. (Marx, idem. P. 277)

A Igreja, na década de 1950, como mostrei no decorrer do trabalho, entra na questão agrária não como uma instituição que assume a posição do campesinato, mas para evitar que ele se constitua como classe, classe para si, como acreditava que os operários se constituíam, em oposição, em conflito, cindindo a sociedade em dois grandes blocos opostos entre si. Para ela, era necessária a convivência e a cooperação entre as classes sociais. Somente no decorrer do seu envolvimento com a sociedade e com os segmentos populares, entre eles, os camponeses e os operários percebem a impossibilidade de constituir a sociedade numa grande comunidade. Cada vez mais, e o processo de modernização do campo vai demonstrando, os interesses entre os segmentos que compõem o campo se opõem e se acirram os interesses e os conflitos.

Recorro à entrevista realizada pelo autor com o Padre Maurizio, vigário de Tauá, onde lembra o processo de expansão do capital industrial e comercial na região que circunda Parambu por volta dos anos oitenta do século passado:

\footnotetext{
Então o conjunto dessa tentativa de ocupação da terra por parte da indústria do caju, da indústria da oiticica, e a tentativa de expulsar o morador para poder libertar a terra e ela poder também ser colocada no Banco, poder ser comercializada, vendida, entrar no mercado de terras era o tempo em que cheguei em Parambu. As comunidades nesse momento viviam essa situação social, econômica, política, respirando no ar e vivendo suas consequências.
}

Os posseiros, era uma área de posse, eram expulsos para em seu lugar se estabelecer o capitalista agrário, monocultor e articulado com a indústria e com os bancos. Como bem percebeu o padre, somente assim a terra interessa ao capital, não interessa como área de subsistência, de agricultura familiar, de produção camponesa. Expulso da terra, o camponês, principalmente aquele que luta, vai se localizar nas proximidades do 
latifúndio, constituindo vilas, ou comunidades na medida em que a situação de expropriado é comum.

Ficou claro que, para segmentos expressivos da Igreja, leigos e religiosos, não há como conciliar interesses divergentes e essa constatação os obriga à tomada de posição, uma posição que é política e ideológica e que contamina sua ação. É nesse processo que se pode dizer que a Igreja, ou segmentos dela se transformam em intelectuais orgânicos das classes subalternas, revendo inclusive a mensagem salvadora para adequá-la aos interesses que desde então representam ${ }^{44}$. Nesse sentido, passam a falar em classes sociais, adotam a pedagogia de Freire e com ela conceitos como classe em si e classe para si, aprofundam estudos sobre o capitalismo e as relações que em seu interior envolvem trabalhadores e burgueses, percebem que 0 desenvolvimento do capitalismo, principalmente nas sociedades periféricas, não ocorre sem que se acirrem as condições de exploração do capital sobre o trabalho.

Nesse processo, as comunidades se transformam e passam a caracterizar a comunidade de iguais e iguais que se assemelham pela pobreza, pela exploração a que estão submetidos pelo capital e por sua oposição ao desenvolvimento das relações de produção capitalista que lhes impede de continuar como camponeses. Mas, no processo, é que se dá afirmação do modo de ser camponês, não há uma regressão, pelo contrário, há sua afirmação como possibilidade de superação do modo de produção capitalista.

Minha tese, a tese que defendo aqui, é a de que ao organizar as comunidades, a Igreja modifica sua visão de sociedade e do socialismo, radicaliza suas posições e evidencia as contradições do desenvolvimento capitalista e assume a construção da classe trabalhadora, principalmente do campesinato, na luta contra a ordem capitalista vigente. Mas, ela não modifica apenas sua visão de sociedade: mudando sua visão de sociedade

\footnotetext{
${ }^{44}$ A esse respeito ajuda a leitura dos capítulo iniciais de Follmann (Vozes, 1985)
} 
vai mudando também sua própria percepção como Igreja. Essa postura de crítica interna ao modo de ser Igreja se constitui no reflexo interno que a ação dos leigos provoca. As estruturas, então existentes, não condizem com a visão modificada na ação dos que estão envolvidos no processo de organização dos trabalhadores; era necessário mudar essas estruturas internas e nesse momento vão sendo geradas as possibilidades de uma outra forma de ser Igreja, uma Igreja que não seja mais apenas hierarquia mas também povo, povo em caminhada. Como o título que nomeia o livro conjunto de Freire e Horton o "Caminho se Faz Caminhando".

Em Crateús, como na sociedade brasileira, vai se gestando a possibilidade de uma nova forma de ser Igreja, Igreja com o povo em sua caminhada, construindo o povo e se construindo ao mesmo tempo como sujeitos, sujeitos políticos em direção a uma nova sociedade. Nessa cidade, formas de organização da ação da Igreja vão se construindo em consonância com as mudanças da Igreja nacional. Assim, antes mesmo da chegada de D. Fragoso a essa cidade, é fundado um núcleo da Juventude Estudantil Católica - JEC e outros movimentos de jovens e paroquianos que passam a atuar na sociedade junto aos segmentos populares. São associações que vão servir de base para a ação posterior de D. Fragoso.

Ao chegar, ele passa a atuar na formação de comunidades rurais dentro de uma perspectiva que já não é a mesma dos anos iniciais da década de 1950 . As comunidades que são geradas a partir da Cáritas e do Movimento de Educação de Base são comunidades dentro de uma perspectiva crítica, com pessoas que vão se constituindo como classe na medida em que não apenas se veem como parte de uma sociedade, mas parte com identidade própria, com interesses próprios e diferentes dos outros segmentos, principalmente com relação aos dos proprietários de terra. Pessoas que vão buscar seu espaço próprio, espaço político de representação de interesses que divergem e são diferentes daqueles que são defendidos por outros segmentos dessa mesma sociedade. 


\section{CAPÍTULO III}

\section{FRAGOSO E O PROCESSO DE CONSTRUÇÃO DOS NOVOS SUJEITOS DA HISTÓRIA}

Não se pode ignorar que na Diocese de Crateús o processo de construção de novos sujeitos das lutas sociais ocorreu, principalmente, com a presença forte e carismática de D. Fragoso. Da mesma maneira vimos que alguns acontecimentos locais, nacionais e mundiais, foram fundamentais no processo de construção de sujeitos históricos. O processo de modernização da economia brasileira com o industrialismo e a utilização de técnicas racionais e máquinas na agricultura, que desloca populações; a inserção social que a Igreja passa a ter, principalmente nessas populações deslocadas, os embates que a envolvem e suas consequências para sua organização interna; o Vaticano II com uma nova visão de Igreja que decorre dos impasses provocados, mundialmente, pela guerra fria e permitiram a abertura na Igreja para a emergência de outras concepções de Igreja são alguns dos acontecimentos que marcaram os anos de 1950 e de 1960, com especialidade, transformando as populações, transformando a Igreja Católica, transformando a sociedade como um todo.

Essas mudanças, mostramos, repercutiram em Crateús mesmo antes da chegada de D. Fragoso com a ação de alguns padres e leigos que se organizaram e passaram a ter uma intervenção mais social nos bairros da cidade onde os problemas da pobreza eram intensos. Mas, essa ação que era muito incipiente torna-se mais intensa com a presença de D. Fragoso. Um Bispo que se mostra e se revela afinado com a emergência de uma Igreja mais comprometida com as questões sociais, com a organização da população mais pobre, com a luta pelos direitos sempre negados ás populações rurais. Mas, principalmente, um Bispo que se não rompe os laços com as elites locais, revela-se independente desta e comprometido com os mais pobres, que diz claramente que sua Igreja será uma Igreja dos mais pobres, comprometida com eles e com suas lutas. 
É interessante, da mesma maneira que fizemos um apanhado dos acontecimentos anteriores ao advento de uma Igreja encarnada, fazer uma análise da história do bispo D. Fragoso, verificar o que constituiu sua personalidade e forjou seus compromissos. Essa sua singularidade assegura, em Crateús, o aparecimento de uma Igreja comprometida com os pobres, libertadora e encarnada.

A história, todos nós sabemos, é o processo de realização do homem, decorre das relações que os homens mantêm uns com os outros a partir do processo de produção da vida, ou dos meios necessários à vida. Essas relações, com aumento das necessidades, vão paulatinamente se transformando, fazendo com que as comunidades primitivas indivisas se transformem em sociedades divididas especializando segmentos dessa mesma sociedade em funções específicas de controle da produção e distribuição, defesa dos interesses comuns, organização e comando centralizado das atividades próprias e necessárias ao conjunto sociedade.

Seguindo a interpretação de Marx e Engels, a necessidade de organização da produção, distribuição, defesa do espaço de produção que é também espaço de cultura; a necessidade de organização das atividades e das pessoas no contexto dessas atividades, próprias a esses setores como um todo, acabam por gerar segmentos, que se sobrepõem ao restante da sociedade, assegurando para si privilégios, na medida em que se apropriam da propriedade comum. Assim, dão origem as classes sociais com interesses diferenciados e opostos, afinal esse processo de apropriação da propriedade comunal não ocorre sem violência. Por isso, no Manifesto do Partido Comunista, Marx e Engels afirmam que "a história de todas as sociedades que existiram até hoje é a história da luta de classes.” (2002, p. $45)$.

A luta que decorre dos interesses que se diferenciam, das necessidades que se opõem e da continuação da apropriação dos bens produzidos por toda sociedade e que acabam se concentrando nas mãos de poucos, é ela sim que produz o movimento incessante de transformação da sociedade e 
explica as formas de organização da produção e distribuição que em determinadas épocas são prevalentes. Nesse processo de transformação da sociedade, as classes se organizam na medida em que seu embate se aprofunda gerando associações que expressam politicamente o que ocorre no mundo da produção e da apropriação, nas relações que os homens mantêm no processo de produção.

As organizações políticas geradas são expressão histórica de um dado momento das relações de produção. São elas que, no embate com as outras formas de organização dos demais segmentos sociais, vão desvendando as contradições, revelando as relações de opressão e apontando as possibilidades abertas pelo mundo da produção, pelas relações de produção, pelo nível tecnológico alcançado, pelas formas de organização e controle que são indispensáveis á manutenção da ordem.

Essa concepção da história assenta, portanto, no
desenvolvimento do processo real da produção, partindo logo
da produção material da vida imediata, e na concepção da
forma de intercâmbio intimamente ligada a este modo de
produção e por ele produzida, ou seja, a sociedade civil nos
seus diversos estádios, como base de toda a história, e bem
assim na representação da sua ação como Estado,
explicando a partir dela todos os diferentes produtos teóricos
e formas da consciência - a religião, a filosofia, a moral, etc-
e estudando a partir destas o seu processo de nascimento;
desse modo, naturalmente, a coisa pode também ser
apresentada na sua totalidade (e por isso também a ação
recíproca destas diferentes facetas umas sobre as outras).
(Marx citado por MARTINS, Francisco in Marx, Gramsci e o
Conhecimento, 2008, p. 98)

As organizações assumem o comportamento de um ser que é expressão de um conjunto unitário, mesmo é claro quando as diferenças de compreensão em seu interior existam, mas ela serve para consolidar uma posição. Esses organismos aparecem, segundo Gramsci, como sujeitos da história, como intelectuais coletivos que no debate educam as classes em confronto. Não é difícil, a partir do que foi dito, colocar na posição do intelectual, daquele que tem no processo histórico um papel fundamental de educador das bases, o indivíduo. O próprio Gramsci analisa a importância do que ele chama de intelectual orgânico, um intelectual que assume um papel fundamental no 
processo de conscientização das classes populares no movimento contrahegemônico ${ }^{45}$.

A Igreja Católica como tal, vai, paulatinamente, assumindo o papel do intelectual orgânico das classes trabalhadoras na medida em que desenvolve seu compromisso com os destinos dessas classes. Antes falei sobre o processo por que passa a Igreja na medida em que se insere nas disputas que ocorrem na sociedade como um todo, transforma-se e transforma sua ação e presença junto às camadas populares. É um processo que se realiza, faz-se historicamente pelas injunções da realidade sociopolítica tornando a Igreja mais susceptível ás pressões dos segmentos populares. Não sei se poderia utilizar o conceito de transformismo de Gramsci nessa situação, já que para ele, esse conceito é preciso em caracterizar a passagem dos intelectuais das classes subalternas "à classe política, para decapitar a direção desses grupos" (PORTELLI. 1983, p.71). No caso presente, o que se tem é o inverso. São os intelectuais tradicionais, ligados à Igreja, que no processo de embate com outras forças políticas mediada por uma realidade de acentuada exploração dos segmentos ou classes populares, acaba por assumir o papel de intelectuais orgânicos dos segmentos dominados, ou classes subalternas como o quer Gramsci.

Mas, a análise de Gramsci da situação italiana, das duas ou três primeiras décadas do século $X X$, indica a função educadora que os intelectuais assumem ao se constituírem como intelectuais dos segmentos populares; para ele, como para Marx antes dele, os trabalhadores, diante de uma realidade compartimentada pela divisão do trabalho, não conseguem perceber a situação de submissão do trabalho ao capital, a condição de trabalho alienado a que estão submetidos pelo processo de produção e de

\footnotetext{
${ }^{45} \mathrm{O}$ conceito de hegemonia utilizado por Gramsci supõe a direção da sociedade a partir da aceitação e não apenas da força, há por parte dos segmentos dominados a aceitação, por acreditar, dos valores, normas e comportamentos das classes dominantes por acreditarem que eles são necessários a manutenção da sociedade,inclusive nos termos e em função dos interesses dos segmentos dominantes. O poder que uma classe exerce sobre a outra não pode ser apenas coercitivo deve ser também hegemônico. Quando me refiro a contra-hegemônico não quero me referir apenas ao aparecimento de uma nova hegemonia que disputa o espaço com a hegemonia dominante, acredito mesmo que é necessário desmantelar a hegemonia dominante, combatê-la, é nesse sentido que me refiro a contrahegemonia. Ver sobre hegemonia o Dicionário de Política, org. por Bobbio.
} 
seus mecanismos de produção e reprodução, de organização e direção do trabalho e da sociedade. Isso não significa que os trabalhadores não sejam capazes de perceber as relações de exploração a que estão submetidos, apenas que para eles é mais difícil uma percepção que vá além da realidade imediata, sentem dificuldade em projetar uma sociedade para além da sociedade capitalista.

\begin{abstract}
É ilusão, sustenta Gramsci, pensar que as classes subalternas, dispersas na multiformidade da sociedade civil, possam chegar à hegemonia só pelo simples desejo e por movimentos parciais e desarticulados, sem constituir-se no terreno sólido da produção, na criação de nova economia e na fundação de nova concepção de Estado. Ainda mais na fase inicial, quando o novo grupo que se organiza passa por um período econômico-corporativo, o conteúdo da hegemonia política é prevalentemente de ordem econômica, pois 'trata-se de reorganizar a estrutura e as relações reais entre os homens e o mundo econômico ou da produção' (SEMERARO, 2001, p. 87)
\end{abstract}

Essa análise, apresentada por Semeraro, indica para os segmentos populares uma impossibilidade decorrente de sua situação objetiva, seus horizontes são fechados pelos muros das fábricas e pela periferia onde residem, por suas necessidades imediatas da sobrevivência e o nível cultural a que são submetidos. Seus saberes, suas práticas, todas elas são expressão do mundo do trabalho em que vivem submersos. Pode-se, é claro, criticar essa visão; o nível corporativo-econômico, pode implicar e implica em relações que extrapolam o meramente econômico e se espraia nos níveis políticos e culturais. A necessidade de educação, a demanda por escolas, os clubes, o sindicato, o espaço do sindicato, da escola, da rua, os contatos que se fazem quando da resolução dos problemas que envolvem o meramente econômico acabam por ampliar a visão e a cosmovisão dos trabalhadores, sua concepção de mundo se amplia mesmo que, na visão de Gramsci, se restrinja ao senso comum.

Para Arendt (2008), a formação dos grupos, das associações, dos clubes, dos partidos, ganha corpo ao longo da existência e da resistência dos trabalhadores. Neles se encontram, dialogam, expressam suas visões 
parcializadas, que ganham corpo e coerência, atingindo níveis mais altos de racionalidade e superando o senso comum até então predominante. As relações de produção, mesmo no seu nível do espaço fabril, se modificam, novas técnicas de produção, novos conhecimentos técnicos, novas formas de organização, novas interações entre setores produtivos, mediações com o estado, afinal o Estado surge como elemento de transferência da luta de classes do espaço fabril para longe dele, para outras esferas que demandam outras lutas e nas lutas originam-se novos processos educativos, novas formas de percepção das relações entre as classes sociais em luta.

Marx, como Gramsci, antes dele, ainda no Manifesto Comunista, chama a atenção para o processo de exploração e a concorrência que se estabelece entre os próprios capitalistas. Para ele, a concorrência entre os capitalistas acaba por provocar a falência de muitos deles que assim acabam na condição de proletários. Proletarizados dão novo impulso aos trabalhadores em sua luta contra a submissão do trabalho ao capital:

As que até agora foram as pequenas camadas médias - os pequenos industriais, os pequenos comerciantes e os que vivem de pequenas rendas, os artesões e os camponeses -, todas essas classes caem no proletariado...

Em geral, os choques da velha sociedade favorecem de diversas maneiras o desenvolvimento do proletariado. A burguesia vive em luta contínua; no início contra a aristocracia; depois contra as partes da própria burguesia cujos interesses entram em conflito com os progressos da indústria; e sempre contra a burguesia dos países estrangeiros. Em todas essas lutas, vê-se obrigada a apelar para o proletariado, a solicitar seu auxílio e arrastá-lo assim para o movimento político. A burguesia mesma, portanto, fornece ao proletariado os elementos de sua própria educação, isto é, armas contra si mesmo.

Além do mais, como já vimos, com o progresso da indústria, frações inteiras da classe dominante são lançadas no proletariado, ou pelo menos ameaçadas em suas condições de existência. Também elas fornecem ao proletariado uma massa de elementos de educação. (MARX E ENGELS. 2002, p. 54)

A classe trabalhadora, nesse processo de desenvolvimento do próprio capitalismo, acaba por incorporar intelectuais dos segmentos dominantes, também formam seus próprios intelectuais, pessoas com capacidade de 
perceber a realidade para além da superfície, enxergando as contradições do capitalismo, tanto na estrutura como na superestrutura, que apontam como uma das suas possibilidades a superação do capitalismo por uma forma superior de organização da sociedade e da produção. Nesse sentido, organizam-se para a disputa da hegemonia no seio da sociedade, para a transformação dessa forma de sociedade em outra superior.

D. Fragoso foi um intelectual ligado a hierarquia da Igreja Católica em um momento em que esta, enquanto intelectual tradicional incorporada como intelectual orgânico da classe dominante, nos embates, modifica sua visão, adere aos segmentos dominados e populares, construindo, com as classes populares, uma visão de mundo diferente da hegemônica. Transforma-se em elemento de conscientização num processo educativo que não apenas aponta as contradições e mazelas do capitalismo, mas também indica a possibilidade de superá-lo. Nesse processo, não apenas educa, conscientiza, mas é pela massa educada e conscientizada. Gostaria de acentuar que o caráter de adesão de segmentos da Igreja aos segmentos populares foi definitivo, não havia como eles voltarem mesmo que a hierarquia refluísse, mesmo que a Igreja a partir do centro modificasse sua postura diante dos segmentos dominados. E isso ocorreu, mas não ocorreu com o retorno dos segmentos que tinham o controle da hierarquia a uma visão consonante com a burguesia dominante, mas porque parte significativa da Igreja não acompanhou a conversão assumida por alguns bispos latinoamericanos, eles continuavam como eram, intelectuais tradicionais numa Igreja que como direção havia aderido aos segmentos dominados.

Maduro (1983) faz essa análise, de maneira competente, ao afirmar que o movimento interno da Igreja expressa o movimento externo da sociedade como um todo; em alguns momentos, dependendo do movimento da sociedade, segmentos afinados com as conjunturas mundiais ou mesmo regionais, aparecem assumindo a direção. Gramsci acentua esse aspecto da Igreja, da sua adaptabilidade a novas situações, inclusive em função de uma certa autonomia, que é assegurada pelo centro como elemento fundamental para manter sua unidade. Assim, as diferenças são e podem ser absorvidas 
e conviverem dentro da mesma instituição que as vai assimilando, de acordo com as injunções externas. Desse modo, a Igreja, de um intelectual tradicional ligada aos segmentos rurais dominantes, passa, no Brasil com a República, a se deixar assimilar pela burguesia nascente, justificando-a e assegurando a hegemonia para essa mesma burguesia, que não dispunha de intelectuais, e instituições sociais, capazes de fazer valer seus interesses sobre a sociedade como um todo.

Modifica-se a Igreja e ao modificar-se fica mais abertamente sujeita aos conflitos que emergem na sociedade com a expansão e modernização do capitalismo periférico brasileiro. Nesse processo conflitam interesses de classe, interesses de segmentos de classe com a invasão de capitais estrangeiros, que acabam concorrendo com os capitais nacionais. Esse tipo de conflito implicou na aliança da burguesia nacional com os trabalhadores brasileiros, afinal havia um inimigo comum a combater. São situações que exigem análise e que focam realidades sociais até então encobertas, descobre situações de exploração e encobre outras que redundam em tomadas de posição por parte de todos os segmentos sociais envolvidos.

D. Fragoso aparece nesse momento, durante os anos de 1950 e 1960, numa Igreja inserida numa realidade social conturbada pelo desenvolvimento do modo capitalista de produção. Trata-se de um capitalismo que moderniza a produção, que mecaniza a produção rural, que incorpora novas fronteiras ao processo produtivo e, com isso, desaloja populações, principalmente as rurais, atrai trabalhadores para os centros urbanos concentrando a população em cidades sem infraestrutura urbana capazes de absorver essas populações; demanda educação, demanda infraestrutura, demanda saúde, demanda principalmente uma legislação trabalhista que defenda os trabalhadores brasileiros, principalmente os do campo. 
Padre Maurízio ${ }^{46}$, atualmente vigário de Tauá, em entrevista cedida a este autor, afirma que ao chegar à Crateús, em 1979, foi encaminhado como vigário para a Paróquia de Parambu. Nesse município e nos municípios da redondeza encontrou os moradores e posseiros em conflito com empresas agrícolas que queriam retomar as terras onde os primeiros cultivavam alimentos e principalmente o algodão. Relatando a história diz:

No momento em que chego em Parambu, nessa época era área de fronteira não somente porque se limita com o Piauí, mas que a expansão do agronegócio estava atingindo aquela região com a expansão do plantio de caju e no final a invasão da produção de óleo da Brasil Oiticica e de coisas assim que estavam ocupando a área da Serra com limite entre o Ceará e - Piauí e retirando os posseiros que há séculos estavam morando lá, uma área de conflitos de conflito de terra numa situação bastante aguda. Era tempo também de reconquista dos sindicatos depois de um tempo mais assim ligados aos problemas assistencial ligado do FUNRURAL. Há uma militância mais explícita de assumir a luta contra a renda, direito as raízes, era o tempo em que o algodão era uma fonte de renda significativa e que os moradores estavam sendo expulsos para o patrão reconquistar o domínio sobre a terra que era colocada em risco pelo crescimento dos direitos dos trabalhadores que tinha raízes de algodão. [...] Então o conjunto dessa tentativa de ocupação da terra por parte da indústria de caju, da indústria de oiticica, e a tentativa de expulsar o morador para poder libertar a terra e ela também ser colocada no banco, poder ser comercializada, ser vendida, entrar no mercado de terras, era o tempo em que cheguei a Parambu.

Ao apresentar a situação vivida em Crateús e arredores, na área de abrangência da Diocese, é porque a situação vivida pelos agricultores de Parambu expressa, de maneira clara, a situação dos trabalhadores agrícolas brasileiros, é a modernização da agricultura que implica inclusive, como diz o padre na entrevista, na liberação da terra para assegurar empréstimos necessários à modernização. Esse processo de expulsão do homem do campo aumenta a necessidade de organização dos trabalhadores em sindicatos e partidos políticos, que exige dos trabalhadores presença política

\footnotetext{
${ }^{46}$ A vinda de Padre Maurizio para Crateús decorre, segundo ele próprio diz, de uma leitura que fez em revista italiana sobre a Diocese de Crateús e sobre o trabalho pastoral de D. Fragoso que assumia a luta do povo como luta da Igreja.
} 
para fazer frente às mudanças que ocorrem de forma intensa, para barrar a exploração do capital sobre o trabalho.

Nos embates, a lgreja modifica posições, assume compromissos, e se aproxima dos trabalhadores principalmente os do campo. Ao incorporar os leigos a sua ação social e política acaba por envolvê-los em lutas que definem posições e estabelecem lados e que exigem da própria Igreja, de leigos e religiosos, a sustentação de suas posições. D. Fragoso aparece nesse momento como muitos outros, assumindo posições e colocando-se ao lado dos mais pobres. Mas, sua presença é diferente e o é por seu papel na Igreja brasileira, como bispo e como dirigente da Juventude Operária Católica em um momento de intensidade política quando os movimentos populares se mobilizavam e se organizavam politicamente. Da mesma forma que parte da Igreja apoia os segmentos populares, D. Fragoso não apenas se posiciona, mas, também se assume como povo, expressando sua vontade e, mais do que isso, abrindo espaço para que esse povo se expresse politicamente estabelecendo seu lado em oposição aos segmentos dominantes.

D. Fragoso pode ser caracterizado como uma liderança carismática, portanto, dotado de liderança insuspeita "seguido pelos que estão em desgraça e seguem-no por acreditarem ser ele extraordinariamente dotado." (WEBER, 1974. P 70). Max Weber dirá ainda sobre o líder carismático "[...] Seus movimentos são entusiásticos, e nesses entusiasmos por vezes as barreiras de classe e status dão lugar à fraternização e aos sentimentos de comunidade exuberantes. Os heróis e profetas carismáticos são, assim, vistos como forças realmente revolucionárias na história." (idem, p. 70)

Para Plekanov, as circunstâncias sociais de um determinado momento forjam os homens exemplares, ou o homem de talento como ele denomina, e faz deles homens com a capacidade de exercer influência sobre os demais e, com isso, cumprirem um papel fundamental no processo histórico: 
São necessárias duas condições para que o homem dotado de certo talento exerça, graças a ele, uma grande influência sobre o curso dos acontecimentos. Em primeiro lugar, é preciso que seu talento corresponda melhor que os outros às necessidades sociais de uma determinada época... Em segundo lugar, o regime social vigente não deve obstruir 0 caminho ao individuo dotado de um determinado talento, necessário e útil justamente no momento em que é preciso. (PLEKANOV. 1971, p. 70)

D. Fragoso surgiu numa época em que as populações rurais se encontravam em efervescência, organizando-se e buscando espaço para o seu fazer política. Surgiu numa Igreja que assumia as lutas populares e assumia com os leigos um papel ativo na construção de novos sujeitos do direito e da história. Claro que ela, nesse momento, não incorporava o novo sem enfrentar contradições internas, mas o espaço político de então, tanto fora da Igreja como internamente, favorecia o aparecimento de certas tendências mais próximas das lutas populares. D. Fragoso surge, nesse momento, como expressão de um segmento da Igreja comprometido com as causas populares e que ao expressá-la o fará em uma região onde o processo de modernização do campo exclui os moradores e pequenos produtores dos latifúndios quebrando uma relação de dependência secular. Sem terra e sem as garantias que os latifundiários Ihes davam, essa população rural sentia-se solta, perdida em relações de produção inteiramente impessoais do modo de produção capitalista. A posição política de D. Fragoso ao defender os direitos e a inserção política dessa população, aparecerá como uma liderança a ser seguida. Aparecerá quase como um "coronel", um homem no qual se apoiar nas dificuldades. Para os camponeses, a força de D. Fragoso se originava, também, do cargo que detinha na hierarquia da Igreja Católica. Era bispo, portanto, tinha força suficiente para protegê-los dos donos do poder e buscar para eles as condições de produção que lhes fora retirada.

\section{Para Plekanov:}

[...] Um homem não é grande porque as suas particularidades individuais imprimem uma fisionomia individual aos grandes acontecimentos históricos, mas porque está dotado de particularidades que tornam o indivíduo mais capaz de servir as grandes necessidades sociais de sua época, surgidas sob 
a influência de causas gerais e particulares. Carlyle, na sua grande obra sobre os heróis, dá-lhes o nome de iniciadores. É uma designação bastante acertada. Um grande homem é precisamente um iniciador porque vê mais longe que os outros e deseja mais fortemente que os outros. Resolve os problemas científicos colocados pelo curso anterior do desenvolvimento intelectual da sociedade; assinala as novas necessidades sociais, criadas pelo anterior desenvolvimento das relações sociais; toma a iniciativa de satisfazer essas necessidades. É um herói. Não no sentido de que pode deter ou modificar o curso natural das coisas, mas no sentido de que a sua atividade constitui uma expressão consciente e livre deste curso necessário e inconsciente. Reside nisto toda a sua importância e toda a sua força. Mas esta importância é colossal e esta força revela-se tremenda. (PLEKANOV, 1971, p. 82)

Desse modo, podemos dizer que D. Fragoso foi um homem exemplar que apareceu na hora certa, num momento em que as condições de produção, na região de Crateús, se modificavam.

\subsection{Fragoso e a Igreja Católica Progressista}

A figura de D. Fragoso marcou fortemente a ação da Diocese de Crateús, não se saberia dizer se nomeado outro bispo, essa diocese teria exercido papel preponderante na construção de uma nova Igreja e de uma sociabilidade mais aberta à mudança, ao debate, à presença dos segmentos populares nas lutas por direitos, no debate político. Essa presença do camponês no espaço público da política lembra Rancière. A presença, por si só, é litigiosa, marcando os fatos e acontecimentos a partir de outra ótica: a ótica dos segmentos populares, daqueles que até então não tiveram direito à expressão dos seus sentimentos, de suas necessidades, de suas aspirações.

D. Fragoso era uma presença forte e comprometida politicamente com os mais pobres. Presença que é fundamental para que os segmentos populares possam acreditar que eles podem e devem participar tanto da Igreja como da sociedade de maneira mais positiva e afirmativa. A presença firme de $D$. Fragoso assegura ao povo da Diocese o direito da fala, da controvérsia, do 
aparecer contrariando o estabelecido que é a não-fala, que é o silêncio dos mais pobres.

Essa força e independência, diante dos poderes constituídos, fazem de D. Fragoso uma figura que passa a concentrar o desejo e a vontade de mudar de todos eles. Ele se coloca à frente e esse colocar-se à frente, como um anteparo, revela o tipo de caráter que o novo bispo tem. Segundo Eliésio (1989),

D. Fragoso chegou em Crateús já vindo de São Luis do Maranhão onde atuou como bispo auxiliar de D. José de Medeiros Delgado. Como padre diocesano da Paraíba e mesmo como bispo auxiliar, D. Fragoso foi, por anos seguidos, assistente da JOC (Juventude Operária Católica). Sua família de camponeses da Serra do Teixeira na Paraíba deu mais dois filhos sacerdotes para a Igreja; [...]

A origem camponesa-religiosa, sua militância na JOC, o seu trabalho intelectual de professor no Seminário da Paraíba são elementos importantes para se compreender a história da diocese que o tem como pastor bem como as acentuações e prioridades do seu pastoreio. (SANTOS. 1989, p. 01)

D. Fragoso era um camponês numa diocese composta, em sua maioria, de fiéis camponeses. Essa característica, um camponês entre outros, indica que ele conhece o terreno sobre o qual pisa, conhece a realidade e as condições de submissão dos camponeses aos proprietários de terra, sabe da psicologia do homem com o qual vai lidar e para o qual assume uma postura diferente daquela que é convencional quando se refere a um bispo da Igreja Católica. É interessante frisar que o próprio $D$. Fragoso se refere à sua atitude inicial diante das autoridades, atitude de independência e de afirmação de uma Igreja renovada que ainda não está consolidada e que se apresenta como radical e contrária aos interesses das oligarquias. Mas, não contrária aos oligarcas, até porque, como ele mesmo diz e reproduzirei adiante, sua Igreja é de todos, desde que se convertam à causa dos pobres e dos mais sofridos. Ao afirmar sua visão de Igreja e de pastoral, a afirma como uma posição sua que depois irá ser confirmada pelos demais que dela e com ele a irão fazer. 
A fala inicial de D. Fragoso expressa uma posição que sabe necessária como tomada de posição que irá posteriormente indicar a sua relação com os demais. Essa maneira de pronunciar a que veio é também um indicativo de que, já que a afirmativa foi pública, não terá outra estrada a seguir senão essa, e nesse sentido indica que a relação que manterá com os demais será a partir e em função desse modelo de Igreja que elegeu. Essa posição que assume em função de sua atuação junto a JOC que com as demais agremiações leigas orientadas pela Ação Católica, radicaliza sua visão de Igreja e sociedade na prática social e política que se constrói no debate mediado pela realidade com as demais concepções e tendências políticas presentes na década de 1950 no Brasil. Mas, nele estão presentes também as discussões que são realizadas em Roma, durante o Concílio Vaticano II do qual participa. Segundo o próprio D. Fragoso:

O bispo também teve a graça de participar do Concílio Vaticano II, que durou oito meses, com 2.300 bispos do mundo todo, setecentos especialistas, além dos papas João XXIII e Paulo VI. O espaço privilegiado foi o encontro de 39 bispos, que nos bastidores das Sessões Conciliares, tentaram aprofundar a Palavra de Jesus: 'quem passa fome sou eu', tirando as conseqüências para a pastoral, para a espiritualidade e para a prática dos cristãos. (FRAGOSO. 2005 p. 51)

Sua participação no Concílio marcou sua visão de Igreja que já vinha sendo modificada a partir dos acontecimentos dos anos de 1950/1960: movimentação de jovens da classe média, dos trabalhadores urbanos e rurais que se organizavam em sindicatos e exigiam mais abertura para sua participação nas decisões políticas a serem tomadas pelos governos populistas de então. A esse respeito, reafirma Alder Júlio:

Experiência que se revelaria de profundo alcance, não apenas para o exercício do pastoreio, mas para sua trajetória existencial, como ele próprio confessaria: 'O Vaticano II marcou fundo a minha vida'. $\mathrm{Na}$ verdade, esta seria uma segunda marca, precedida e fortalecida que fora pela sua fecunda experiência de trabalho como assistente da JOC (Juventude Operária Católica, um dos segmentos mais expressivos da Ação Católica especializada), durante dez anos, impactando vivamente seu processo de conversão: 'A JOC me abriu os olhos para a realidade do mundo dos 
pobres'. Experiências por sua vez consolidadas pela sua participação nos bastidores do Concílio, ao acompanhar as reuniões de um grupo de bispos que se reuniam no Colégio Belga para refletirem, de forma mais comprometida, no lugar dos pobres na pedagogia de Jesus. (JÚLIO. 2005, p. 167)

Participação que se dava focada, como diz o autor em pauta, nos pobres e na realidade do mundo subdesenvolvido da periferia, principalmente na América Latina e na África. Esses bispos que de alguma maneira tiveram influência sobre a formação ou conversão de D. Fragoso, acreditavam que a Igreja teria que mudar sua postura com os mais pobres como também mudar a prioridade da Igreja nesses países. Para eles, a ação da Igreja Católica no terceiro mundo deveria ser pautada em reformas sociais e políticas que evitassem a conversão desses povos ao marxismo revolucionário. Só que o antimarxismo que esses bispos professavam, que era uma preocupação do Papa João XXIII, não era uma oposição cega, mas uma oposição que decorria do materialismo que a doutrina marxista professava.

Tanto é verdade que muitos dos bispos e padres que se comprometeram com um cristianismo mais social, valeram-se da metodologia e da ciência de Marx para melhor perceber as contradições do capitalismo e posteriormente elaborarem uma crítica mais radical ao próprio capitalismo. Para eles, o que se colocava como objetivo era uma sociedade sem injustiças, voltadas para os mais pobres e construída a partir da participação desses. D. Fragoso compartilhava dessa visão e em seu livro UM ROSTO DE UMA IGREJA assim se pronuncia:

Não temos as portas fechadas para o instrumental científico de análise da sociedade capitalista, que Marx oferece, pelo fato de vir de Marx. Na medida em que for verdadeiro, não é mais de Marx, é da humanidade. Achei muito interessante ser convidado por um grupo de bispos para participar de encontro sobre instrumento de análise da realidade sob a responsabilidade de teólogos e expertos em ciências sociais de alta categoria. $O$ curso ajuda-nos a conhecer também 0 que é mesmo de Marx nos marxismos e o que é de seus discípulos. Ajudou-nos a ler, à luz da fé, o projeto marxista: instrumental científico de análise, a concepção materialista da história, o método dialético, etc.

Penso que, para sermos honestos diante da nossa consciência de cristãos, devemos acolher o marxismo e todas 
as outras contribuições que os homens estão oferecendo para uma análise realista da situação. (FRAGOSO. 2005, p. 87)

Sua postura era de abertura para o mundo, abertura que o fez aproximar-se de todos os segmentos sociais, mas era uma postura de abertura crítica, sempre atenta para as possibilidades, possibilidades que seguia na medida em que asseguravam o advento de um novo mundo de justiça, paz, liberdade e igualdade. Sua visão do homem era aquela que indicava a autonomia do mesmo, que poderia construir a autonomia dos homens, com e pelos homens. Não queria tutelar, mesmo que em determinados momentos tenha tomado atitudes que conduziram a caminhos diferentes daqueles que se poderia esperar das possibilidades apresentadas no seu espaço pelos homens que com ele viviam e conviviam. Nesse sentido, foi sua decisão, no primeiro dia de seu bispado, assumir que sua Igreja seria uma Igreja diferente, seria uma Igreja dos pobres e para os pobres, mas, também, era aberta para todos que lutassem pelos direitos e pela autonomia política e social dos mais pobres. Depois se penitencia por não ter consultado ninguém, mas o momento exigia e parece que D. Fragoso tinha a percepção do tempo certo para as atitudes que assumia.

Da mesma maneira foi também uma decisão sua, se bem que compartilhada com os demais, mas não se pode ignorar sua influência sobre todos na medida em que era o bispo, de romper com a Cáritas e com O MEB. Razões existiam, discutíveis sim, e é problematizada por C. Boff (1989), mas a posição que assumiu e para a qual convenceu os demais teve um caráter educativo e urgente; era necessário uma lgreja que fosse fruto verdadeiro dos pobres de Crateús, assumindo eles próprios a Igreja que queriam para si. Sua postura era sempre educativa e como o professor freiriano, outra influência muito forte na sua formação, escolhe as palavras chaves do arsenal das palavras usadas entre aqueles que se quer educar, ele escolhe tendo em vista as possibilidades que as palavras revelam quanto às sílabas, à fonética e a geração de novas palavras, também dentro do universo dos educandos. O professor, mesmo numa pedagogia que se quer libertadora, escolhe, escolhe o espaço dentro do qual pretende jogar, mas não evita que 
esse espaço seja questionado, pelo contrário, ele também o quer questionado.

A influência da pedagogia freiriana é fundamental para a prática pedagógica de D. Fragoso. Assim, ele se expressa ao falar de participação e libertação:

Esta caminhada não se improvisa. O povo do campo carrega o opressor dentro de si. E não tem confiança no pobre, porque sempre viu que ninguém acredita no pobre.

Daí nasce a necessidade permanente de formação.

Formação não é formação, de forma(ô). Quando colocamos as pessoas dentro de uma forma(ô) nós a violentamos. Nosso inspirador principal foi Paulo Freire e sua metodologia para superar a opressão, tendo sempre o povo do campo como agente insubstituível de sua própria formação.

Esse processo formativo cruzou todos os momentos da caminhada das CEBs. (FRAGOSO. 2005, p. 45)

Com Freire aprende que o caminho a ser trilhado em direção à libertação somente se faz quando, mediados pela realidade envolvente, os homens aprendem a dialogar uns com os outros, respeitando o tempo de cada um, pois a libertação não ocorre individualmente, ela é um processo que implica na construção de um sujeito coletivo, capaz de agir coletivamente a partir da vontade de todos. Mais do que perceber essa verdade, ele compreende com Freire que a libertação implica também na libertação de cada um. Somente homens livres são capazes de dialogar, e somente homens livres e que não oprimem, pois o opressor, segundo o próprio Freire, precisa libertar-se como cada um de nós por vivermos em um mundo de opressão, não aprendemos senão a sermos submissos ou opressores, dependendo da posição social e política de cada um.

A formação de D. Fragoso, assim, estaria assentada em alguns pilares fundamentais na construção de seu compromisso com os mais pobres numa dimensão religiosa, social e política. Os pilares que sustentam sua opção pelos mais pobres estariam apoiados, fortemente, na sua origem numa família camponesa pobre num momento de modernização do campo, na sua passagem ativa, pois coordenador, na Juventude Operária Católica, e isso num momento de aceleração histórica em que a Igreja teve que confrontar 
com outras concepções de sociedade e com a emergência das camadas populares, trabalhadores e camponeses, com a criação dos círculos de leitura promovidos a partir da pedagogia freiriana, e do Concílio Vaticano II quando a Igreja Católica voltou-se para os mais pobres, preocupada que estava com o aumento da pobreza entre os países do chamado terceiro mundo.

Alder Júlio (2005), que com D. Fragoso e outros escreveram o livro A Igreja de Crateús, ao analisar o aparecimento da CEBs assim se expressa:

Em que pese a relação antagônica entre umas e outras, o nascimento das CEBs no Brasil coincide, em parte com o início da ditadura militar. O Golpe de Estado de 1964 se deu no momento em que as forças sociais populares do campo e da cidade intensificavam as pressões pelas famosas reformas de base - a reforma agrária e a reforma educacional ocupando lugar de destaque -, graças, de um lado, às intensas mobilizações das Ligas Camponesas e às lutas por direitos trabalhistas no campo, por meio sobretudo da recémcriada CONTAG (Confederação Nacional dos Trabalhadores na Agricultura) e respectivas federações estaduais e, nos municípios, os Sindicatos de Trabalhadores Rurais, e, do outro lado, ao grau de organização e de mobilização alcançado então pelos estudantes, seja no âmbito universitário (UNE), seja no seio do movimento secundarista ambos respaldados por fecundas experiências de cultura popular, como os Centros Populares de Cultura (CPCs) protagonizados pela própria UNE, e pelo Movimento de Cultura Popular, com os freirianos 'circulos de cultura' -, além do eficaz apoio da chamada Ação Católica especializada, respectivamente JEC (Juventude Estudantil Católica) e a JUC (Juventude Universitária Católica).

Era uma época de grandes iniciativas das camadas populares e médias, animadas pelos estudantes e setores progressistas da Igreja Católica, seja mediante o Movimento de Cultura Popular, seja por meio dos Centros Populares de Cultura, com crescente influência da pedagogia freiriana, sobretudo no campo da alfabetização de adultos, dentro da campanha nacional desencadeada pelo governo de Jango, em parceria com setores da CNBB, através do Movimento de Educação de Base, de alcance nacional, contando com um criativo sistema de radiofonia utilizado à luz do sistema Paulo Freire de Alfabetização de Adultos. (p. 278)

O que o autor situa como a conjuntura favorável ao aparecimento das Comunidades Eclesiais de Base serve para situar D. Fragoso, sua formação como padre comprometido com as questões populares e como futuro bispo 
de Crateús. Sem esse 'caldo' onde os embates eram constantes e a emergência das forças populares, que eram disputadas por segmentos políticos dos mais diversos matizes, não teria sido possível a aparição de maneira tão afirmativa do bispo de Crateús.

\subsection{Fragoso chega à Crateús e Afirma Compromisso da Igreja com os Pobres}

É marcante o momento da chegada de D. Fragoso a Crateús, marcante porque se coloca de maneira clara, define sua posição e seu papel no contexto da Igreja, da sociedade e principalmente no contexto da região de Crateús. Marca posição independentemente das autoridades presentes, e pela presença das autoridades essa tomada de posição é exemplar, afigurase desde o começo como uma pessoa destemida, capaz de enfrentar as situações mais adversas.

É um bispo, parte integrante da hierarquia da Igreja numa posição privilegiada, no entanto é capaz de mostrar uma faceta da Igreja até então desconhecida das pessoas presentes na sua recepção, ao contrário do bispo de Sobral, e ele deixa clara essa diferença no discurso inicial, não se coloca à disposição dos ricos e poderosos da região, mas se coloca, e o diz de maneira clara, ao lado dos pobres, dos menos afortunados, dos mais sofridos. Importante nesse contexto é que não se coloca como aquele que irá redimir os pobres, mas aquele que junto com os pobres, irá construir uma nova Igreja, uma lgreja dos pobres, para os pobres e com os pobres.

Nesse discurso inicial, D. Fragoso faz toda a expressão do que representa sua vinda para Crateús, sua visão de Igreja, sua visão de sociedade, sua crítica às estruturas econômicas e políticas de então e de sua pastoral, afinada com o Concílio Vaticano II e com os segmentos populares. Vejamos o que diz: 
Fui saudado por Claudino Sales, Dr. Salim, como o chamamos. Depois chegou a ser deputado estadual, secretário de Estado, presidente da Assembléia Legislativa do Ceará e deputado federal. E era dono da única industria existente em Crateús.

Ele me saudou com efusões de alegria, com palavras muito amáveis e simpáticas. Como D. José Tupinambá da Frota (meu antecessor na diocese de Sobral, que incluía oito paróquias das dez de Crateús) dera um nome a Sobral, construíra civilização, fazendo faculdades, colégios, hospitais, museus, orfanatos, asilos - esperavam que o novo bispo, Antonio Batista Fragoso, desse nome à cidade de Crateús, fosse também construtor de civilização. (Fragoso. 1982, p. 14)

Essa era a expectativa, que D. Fragoso desse continuidade ao trabalho e a pastoral de $\mathrm{D}$. José Tubinambá, que ele se voltasse para o desenvolvimento da região, que construísse obras para atendimento da população, atacando os efeitos e não as causas das necessidades da população. Obras de caridade para aqui e ali dirimir os efeitos da pobreza e da miséria, mas não era essa a preocupação do novo bispo, não era fazer uma Igreja amiga dos ricos e caridosa com os pobres, seu objetivo era outro, era fazer uma lgreja com os pobres, atacando as causas da pobreza, buscando as razões da mesma e denunciando as injustiças; era uma lgreja voltada para os direitos dos homens, principalmente os direitos que eram negados aos mais pobres, assegurando-os como direitos conquistados pela força da organização.

Continuando o depoimento de D. Fragoso, ele passa a descrever o modelo de Igreja que pretende construir na diocese:

Esse modelo de Igreja-povo se manifesta em Crateús, no seu
período de gestação.
Toda a Igreja é chamada a tornar-se o POVO DE DEUS,
convocado pela Palavra e testemunhando Jesus Cristo, seu
senhor, em quem acredita.
Para mim a Igreja Popular é a Igreja dos oprimidos, dos
pequenos, dos pobres, dos fracos, reunidos nos seus espaços
de base que chamamos de COMUNIDADES ECLESIAIS DE
BASE. Assim, no interior da grande Igreja-Povo, está
emergindo a Igreja Popular. (FRAGOSO. 1982, p 59)

A divergência estava marcada, era o próprio bispo que delimitava sua ação e a diferenciava da ação reverenciada pelos segmentos dominantes da região. Nessa resposta estava embutida uma visão de lgreja que os poderosos não 
podiam admitir: a autonomia. Mas não era apenas autonomia, era uma autonomia assegurada pela fé, a fé cristã, católica que sempre procurou tutelar os seus fiéis. Era uma nova leitura do cristianismo que aparecia, que não determinava posições nem ações, que não aparecia para dizer o certo e o errado, aparecia apenas para animar, mover, fazer com que os fiéis, animados por ela, caminhassem em direção ao futuro na resolução dos seus problemas e no atendimento de suas necessidades. Autonomia na fé, nada impediria a construção também da autonomia política e econômica.

Mas outras questões irão aparecer nesse primeiro momento que distanciará, ou pelo menos, colocará em alerta os donos do poder no Sertão de Crateús. D. Fragoso não aceitará a construção de um seminário menor justificando não ter padres e recursos em quantidade suficiente para fazer frente a essa empreitada. Aceitá-la, seria aceitar a ajuda financeira dos mais ricos, criar vínculos que queria não ter já que pretendia assumir uma Igreja livre do compromisso com segmentos para ser servidora de todos.

Mais além, ao ser abordado pelo governador de então, o coronel Virgílio Távora, sobre a possibilidade de estabelecer convênio com a Diocese, D. Fragoso rejeita. Vejamos como ele coloca essa conversa que teve com Virgílio:

Chegando a casa de bispo, o governador Virgílio Távora me chamou e disse: 'Olhe, eu já fiz convênio com a arquidiocese de Fortaleza e com outras dioceses do Ceará. Estou oferecendo convênios com a sua diocese que começa'.

Respondi: 'Governador, a minha intenção é aquela que explicitei, há pouco. Não farei nenhum convênio com o governo. Não farei obras, aqui. Meu trabalho é, fundamentalmente, o de educador da consciência, à luz da fé, para que a comunidade cristã assuma com os outros os serviços necessários. Se convênios houver, sejam da comunidade e não do bispo, nem dos padres. (ibidem, 15)

Sua posição assumida diante das autoridades, acompanhada pela população que foi à praça pública para recebê-lo, foi um ato educativo sem igual que ele compreende quando afirma para o governador que é um "educador da consciência", termo usado amplamente por Freire e por 
quantos fazem a educação popular a partir da pedagogia desse educador. Consciência que compreende não apenas a percepção da realidade, mas a partir dela se esforça para mudar e superar essa mesma realidade que é opressora. Portanto, mais uma vez deixava claro que era diferente do seu antecessor, que estava ali para animar a caminhada do povo, dos segmentos populares, contribuir para a libertação desses segmentos, que compreendia a Igreja como motivadora dessa caminhada, a iluminar os caminhos para a libertação a partir da palavra revelada e da fé em Cristo Salvador.

Mas, outros eventos ocorreram nesse primeiro momento que considero exemplarmente educativos. Não se pode esquecer que 0 ato educativo ocorre entre pessoas que se abrem uma para a outra mediada pela realidade que as envolve. Nessa relação, a finalidade desse ato educativo é ensinar, propiciar novo conhecimento ou a percepção do velho a partir de outra perspectiva, ato que muda, transforma as pessoas envolvidas, pois implica na objetivação da subjetividade de cada um, subjetividade que vem carregada de história pessoal e coletiva, e das imbricações das mesmas, fazendo com que os envolvidos incorporem a historicidade que cada um carrega. A presença do outro nunca é vã, pois acrescenta a carga que cada um trás, a visão e concepção do outro. Sendo uma das pessoas exemplar, destacada do comum por sua situação objetiva pessoalmente, culturalmente ou institucionalmente, sua presença e suas atitudes, porque exposta e pelo fascínio que exerce sobre as demais, marcam, só que marcam os que têm história e também estão situados social e economicamente. Os camponeses de Crateús têm história, história de submissão, de subalternidade, de compromissos, mas também história de transição, transição de uma situação de ocupação para a não-ocupação, de produtor familiar, para a condição de assalariado temporário, de protegido, para a condição de desprotegido por não ser mais necessário à produção agrícola modernizada.

Assim, a tomada de posição pública de D. Fragoso teve o efeito de ser educativa. Era o outro que continuava outro, mesmo sob a pressão para ser o mesmo, aquele que se afirma diferente dentro de uma estrutura de poder 
que se pretende sempre igual a si mesma, como era a Igreja e a sociedade rural brasileira, principalmente. $E$, desse modo, também não demoram as perseguições que sofrerá como consequência por seus atos de independência e autonomia diante dos poderes constituídos. A resposta mais imediata vem quando da proposta de uma rádio para a Diocese. Vejamos o diálogo que mantém com o ex-ministro da Viação de João Goulart:

\footnotetext{
Estava ainda na Arquidiocese de S. Luis do Maranhão, quando recebi uma carta de um crateuense bem informado: 'Há uma grande expectativa, aqui, em Crateús, em torno do seu novo bispo. Comunico-lhe que o ministro da Viação, crateuense, Expedito Machado, obteve a concessão de uma rádio - a Rádio Educadora de Crateús - para oferecer à diocese. Nós esperamos só que o Sr. Chegue para tomar posse dela.'

De fato, parece ter sido verdade. Logo após a queda de João Goulart, de quem expedito Machado era ministro da Viação, este viajara para o exterior. Em Roma, durante o Concílio Vaticano II, eu me encontrei com ele e sua senhora. Disseme: 'Olhe, a Fundação Pedro Machado e a Rádio Educadora, eu quero entregar à diocese de Crateús.'

Minha resposta era a mesma: repetia o que dissera ao povo e ao Dr. Salim, no dia da chegada. O bispo de Crateús não seria construtor de civilização. Não considero essa missão minha. A minha será uma discreta missão de serviço ao povo de Crateús, para que assuma o destino de sua terra. Se a comunidade assumir a Rádio e esta for um serviço ao povo, fico feliz.

Ele me disse: 'Não the dou cinco anos para que esteja arrependido.'

Isto aconteceu em 1964. Em 1969, a Diocese foi proibida de acesso à Radio Educadora, durante onze anos. (FRAGOSO. 1982, p. 16)
}

D. Fragoso era consciente de seu papel tanto na Igreja como na sociedade, sua posse, aliás, foi marcada por dois acontecimentos ímpares: o Concilio Vaticano II que abria a Igreja Católica para a participação mais afirmativa do leigo, uma Igreja que a partir de então se queria dos pobres, dos injustiçados e dos marginalizados, mas não para acomodá-los à ordem e sim para mudar as estruturas vigentes que produziam e reproduziam as condições da pobreza, da injustiça e de marginalização; e a instauração da ditadura militar no Brasil que fechava a sociedade, que impedia a livre manifestação da fala, que perseguia os líderes políticos que emergiram no quadro da aparição dos 
movimentos populares, que acabava com os partidos políticos, canais institucionais da política. Mas, a situação em que se encontrava o País não o assustou, não o intimidou, pelo contrário o instigou a uma ação política, social e religiosa condizente com os seus princípios e os princípios da lgreja Conciliar. Sua posição em Crateús denota essa coragem e esse compromisso. Assim consegue colaboradores que com ele vão assumir o pastoreio para a libertação. Em Crateús, a Igreja se oferece como espaço da política e da participação, da conscientização e da construção de novas formas de fazer política, formas que só o povo, em conjunto, pode fazer.

É interessante, nesse ponto, refletir sobre a análise que Luiz Gonzaga Gonçalves faz da trajetória de D. Fragoso e da Diocese de Crateús. Nessa análise, sem querer diminuir a Diocese de Crateús, mas enxergando-a como realmente era, uma diocese do interior, longe dos grandes centros urbanos e dos aglomerados de trabalhadores-operários, afinal D. Fragoso havia sido coordenador da JOC, numa zona predominantemente agrícola, longe dos centros de decisão política e religiosa, aponta a ida de D. Fragoso para essa Diocese como um exílio, quietá-lo sem possibilidade de conjurar sobre a ordem que mantém a maioria da população em condições de sofrimento e pobreza. Assim se pronuncia o autor referido:

Mas como entender o fato de D. Fragoso, em 09 de agosto de 1964, ter sido designado a assumir a diocese de Crateús? Deve ser lembrado que, na ordem das coisas, tudo o levava a ser o sucessor natural de D. José Medeiros Delgado em S. Luis do Maranhão, onde havia atuado como bispo auxiliar durante sete anos.

Muito embora falte uma explicação oficial a cerca da não indicação de seu nome para aquela arquidiocese, inclusive recomendado pelo próprio $D$. Delgado, é provável que isso se deva ao seu vínculo efetivo com os compromissos e projetos da Ação Católica Especializada (JOC, JEC, JAC, ACO).

[...] Quanto aos fatos concretos, teria circulado uma notícia na imprensa a cerca da prisão de um militante de esquerda, participante da JOC de S. Luis, com o qual teriam sido encontradas duas cartas de D. Fragoso. Aí estaria certamente, a gota d'água para os militares e grupos tradicionais associarem D. Fragoso com a subversão e o comunismo.

Em entrevista concedida a Antonio Montenegro em fevereiro de 1998, o padre francês, Xavier Gilles de Maupeau, que foi recebido no Brasil por D. Fragoso, admite que, naquela 
conjuntura, as pressões externas levaram o bispo a ser transferido para 'o fim do mundo', para Crateús no interior do Ceará. (GONÇALVES. 2004, p. 120)

Não é de se estranhar, apesar do Concílio Vaticano, há no País uma predominância de bispos conservadores, basta vê a forma como foi recebida pela Igreja a ditadura de 1964. No entanto, não sei se teria havido alguma pressão dos militares na medida em que as datas não coincidem com aquelas anotadas por Eliésio dos Santos, padre da Diocese de Crateús e um dos principais protagonistas da história daquela Diocese. Vejamos:

A criação da diocese de Crateús se deu em 28 de setembro de 1963. Foi o papa Paulo VI quem a criou. A nomeação do seu primeiro bispo, D. Antonio Batista Fragoso, foi no dia 28 de abril de 1964 sendo a sua posse e a instalação da diocese no dia 9 de agosto do mesmo ano. (SANTOS. 1989, p. 01)

São datas muito próximas, vinte e oito dias, para que os militares no poder pudessem ter a avaliação da figura de D. Fragoso e intervir junto a Igreja, num momento em que ela passava por mudanças significativas assumindo, inclusive, compromissos com os segmentos populares. Claro que parte do clero e da hierarquia apoiou o golpe e saíram às ruas para confirmar, diante da sociedade, esse apoio. Talvez a iniciativa tenha sido tomada por bispos com posição de destaque na Igreja do Brasil e influenciado Roma para distanciar D. Fragoso dos acontecimentos de então. De qualquer maneira, Gonçalves levanta uma possibilidade que não deve ser descartada sem maior análise.

No entanto, mesmo numa diocese da periferia, no interior de um estado que não se situava entre os estados mais importantes, com uma economia muito mais rural que urbana, mesmo assim D. Fragoso com sua ação junto às populações rurais renovou o fazer lgreja e o fazer política, isso em um período ditatorial de perseguições, prisões, pressões dos militares e de seus correligionários. D. Fragoso sofreu na pele esse momento, foi mais de uma vez chamado a depor, várias vezes padres e leigos de sua diocese foram presos ou levados para depoimentos. Santos relata, pormenorizadamente, 
as perseguições que os membros da equipe da Diocese sofreram, principalmente nos anos de 1970:

É também em 1970 que ocorre a primeira perseguição sistemática a diocese. Antes houvera ensaios, escaramuças com infiltração e espionagem em vários pontos, campanha de difamação na rádio local e nos jornais, tudo com o fito de denegrir o nome da diocese e do bispo. Mas é em 1971 que ocorre a prisão do Padre Geraldo de Oliveira Lima, vigário de Novo Oriente e a prisão e expulsão do país do Padre Pedâdola, missionário italiano, que trabalhava na equipe paroquial de Tauá, responsável pelas paróquias de Tauá e Parambu. Vários líderes sindicais de Tauá e Parambu foram perseguidos e presos. (SANTOS. 1989, p. 08)

Esses fatos acontecem em função do trabalho de sindicalização dos trabalhadores rurais nos municípios da Diocese, da ação educativa iniciada com discussões sobre as leis que protegem os trabalhadores rurais e os protegem da exploração a que estão submetidos pelos proprietários de terra. O trabalhador rural tem direitos, esses direitos existem e devem ser aplicados na defesa dos interesses dos trabalhadores; devem ser reconhecidos e confirmados na justiça sempre acionada quando necessário. Essa era a questão básica, o mando, o controle sobre os trabalhadores pelos proprietários latifundiários estava ameaçado, os juízes não podiam mais desconhecê-los ou escamoteá-los, os sindicatos organizados, a Diocese através de sua ação junto aos trabalhadores orientava e apoiava os trabalhadores, os sindicatos contratavam advogados. Tudo isso, quebrava a relação de poder existente e deixava os proprietários em alerta, sempre que podiam denunciavam a ação desestabilizadora da Diocese, acusava-a de comunista e a presença de um Batalhão de Engenharia na cidade de Crateús facilitava esse comportamento das elites regionais.

D. Fragoso estava associado a uma visão de lgreja que se mantém independente dos poderes civis e militares, uma visão que voltava a ação pastoral para os mais pobres e injustiçados (essa palavra denotava a condição de sem direitos, os sem cobertura da justiça, os sem autonomia, reconhecidos somente sob as asas dos senhores) é claro que o bispo, seus padres e leigos eram uma ameaça ao poder ditatorial como o era o poder 
dos donos. Por isso, as perseguições e o reconhecimento da proeminência da figura de D. Fragoso. Situação que o coloca no centro das discussões, como uma figura central na reação contra o regime militar e assim, apesar de tudo, ele aparece e sua ação é vislumbrada nacionalmente servindo de exemplo para leigos e religiosos.

Aparece, também, para a Igreja. Mesmo estando D. Fragoso em uma diocese situada na periferia, sua ação invade o centro e o torna figura visível e exemplar a influenciar outras ações, inclusive a questionar a estrutura oficial da Igreja no Brasil. Basta relacionar as figuras expressivas da Igreja do Brasil que acompanharam de perto a experiência de Igreja implantada ou em implantação em Crateús. Dentre essas figuras nacionais estão religiosos como Clodovis Boff, Frei Beto, Comblin, Mesters, Ribeiro e tantos outros. Todos eles passavam por Crateús para ver o novo e ajudar na reflexão sobre o modelo de Igreja que D. Fragoso, juntamente com a comunidade católica da Diocese de Crateús, tentava implantar.

\subsection{Construindo uma Nova Forma de Ser Igreja}

Para D. Fragoso, a Igreja não poderia situar-se à parte do povo pobre. Ele deveria estar junto com o povo e se fazer com o povo, nas suas lutas, na percepção das contradições e da exploração em que se vivia, ser educadora e conscientizadora. Não bastava, como a Igreja tradicional, apenas confortar os que sofriam as injustiças e os famintos. Ele deveria, junto com o povo, buscar as razões do sofrimento, da injustiça e da fome, combatê-las, mas não era o papel dela ser o sujeito da superação das razões e causas do sofrimento e da fome, o sujeito deveria ser todos os homens, todos aqueles a quem se negavam os direitos a humanidade. O papel da Igreja era animar, estimular e educar o próprio povo para que ele atuasse no sentido de sua libertação. 
Essa Igreja educadora, que desperta o homem para sua condição de oprimido, deveria também libertar-se dos compromissos construídos ao longo do tempo com os segmentos dominantes, abrir-se para os leigos, fazê-los coparticipantes da construção de um novo modelo de Igreja. No seu livro $O$ Rosto de Uma Igreja, ele descreve dois modelos de Igreja e os critica:

No interior desta história, está escondido, a meu ver, um PROJETO OU MODELO DE IGREJA. Chamo de modelo um projeto que se encarna na prática. Não é um exemplo para os outros seguirem... É uma espécie de modelo emergente de dentro de uma prática, sobre a qual refletimos coletivamente e de modo constante.

Parece-me que tínhamos em Crateús, e ainda temos majoritariamente, uma Igreja tradicional. Para mim, a Igreja de Crateús é, em sua maioria, tradicional, conservadora, moderada. Não é, predominantemente, revolucionária. Não é uma Igreja avançada.

A Igreja de Crateús repete e realiza duas imagens históricas de Igreja: a Piramidal e a de Centro-Periferia. (1982, p. 57)

Ele, ao contrário, quer para Crateús, uma Igreja encarnada, o que para mim significa está junto com o povo, no meio de povo, uma Igreja feita corpo, concreta, incorporando as lutas, vivendo a vida do povo com ele, coletivamente, uma Igreja que se faz na história com a história, que se faz para fora de si, junto com todos, coletivamente e mais do que isso, uma Igreja revolucionária que rompe com o presente da Igreja tradicional, para ser diferente, ultrapassando a sua forma atual, buscando uma nova forma na participação de todos. A construção de uma Igreja não deve ficar à mercê do seu corpo hierárquico, de sua burocracia interna, ela deve está aberta, compreender que somente é Igreja se compreende igualmente religiosos e leigos, se encarnada na vida de todos, vivendo suas realidades, sua história, sendo, porque esse conjunto, a história de todos eles.

Para ficar clara sua opção de Igreja, opção que inicialmente introduz ao se dirigir as autoridades e ao povo de Crateús quando de sua chegada, quando afirma que sua Igreja era uma Igreja para os pobres, com os pobres:

Isto marcou, evidentemente, o caminho, na encruzilhada. Foi uma tomada de posição arriscada. De um lado, eu estava frustrando a expectativa quanto ao bispo que chegava. Do 
outro lado, estava marcando uma tomada de posição, antes de ouvir o clero e os leigos, para saber se este era o pensamento de todos ou não. Não sendo um diplomata, só me lembrava de que devia ser coerente com minha consciência, pelo menos quando falava. (idem, p. 15)

Sua posição estava mais do que clara, mesmo acreditando que sua Igreja era um processo de construção conjunto, sua tomada de posição inicial indica que sua opção estava feita, era essa, depois era convencer, apresentar e quem sabe afirmar, reafirmar esse projeto com todos os demais. Sabe-se, como ele mesmo diz quando se refere aos modelos de Igreja, que a maioria da Igreja de Crateús era tradicional, conservadora, mas isso não o inibe, nem o faz recuar e não entende como uma afronta à democracia, já que queria a participação de todos, até porque sua afirmativa era um indício de que não obrigou os demais o seguirem, não fechou o caminho tradicional. É interessante frisar o alerta de Comblin, já citado, de que a Igreja tradicional permanecia e se corria o risco se se retornar por inteiro a esse modelo tradicional de Igreja num momento posterior com uma possível saída de D. Fragoso.

Mas, D. Fragoso sabia disso, afinal ele queria construir uma nova Igreja, mas sabia que não poderia obrigar os demais a assumirem com ele essa posição, não seria democrático e seria com essa atitude mais um bispo autoritário e tradicional. Assim, trabalha no sentido da renovação, reforça as posições revolucionárias esperando que sua existência possa levar os demais a assumirem esse modelo, esgotando o outro.

$\mathrm{Na}$ descrição do modelo tradicional ele chama a atenção para suas características:

A Igreja de Crateús repete e realiza duas imagens históricas de Igreja: a Piramidal e a de Centro - Periferia.

Segundo a imagem piramidal, a Igreja é uma Pirâmide, em cujo ápice está a hierarquia, que tem a missão de ensinar e a assistência do Espírito Santo para, nos domínios da Fé e dos Costumes, interpretar, autêntica e infalivelmente, o Depósito revelado. Na base está o povo fiel que deve acolher na Fé a proposta da hierarquia e obedecer de modo constante. O 
povo fiel se santificará pelo exercício do acolhimento e da obediência à proposta da hierarquia.

[...] Penso que o Vaticano realiza, ainda hoje, de modo muito constante, esse modelo de Igreja.

Segundo a imagem de Centro-Periferia, na Igreja Universal, o centro toma as decisões e controla a fidelidade das Igrejas Periféricas. Na Igreja Particular, se repete o modelo da Igreja Universal. As Igrejas Particulares - ou as bases - seriam como satélites imantados pelo centro. As Igrejas Particulares - ou as bases - não têm autonomia própria, a não ser a autonomia outorgada ou concedida pela Igreja Central. Neste sentido não seriam plenamente Igreja. (FRAGOSO. 1982, p. 57)

O autor ainda se refere a um modelo clerical de Igreja que centra sua ação nos padres, ou no clero, ficando aos leigos no papel de colaboradores. Os leigos não teriam papel ativo, não seriam Igreja no sentido pretendido por D. Fragoso a partir do Concílio Vaticano II. Teriam um papel secundário, não poderiam nem teriam essa função de influenciar as ações meramente religiosas da própria Igreja. A pretensão de D. Fragoso era a instituição que agregasse todos, tornando-os corresponsáveis pela Igreja, que não teria apenas a função institucional, mas seria encarnada ajudando e juntamente com os homens ser a Igreja viva, histórica e também supra-histórica, compreendendo o Reino não como o fim e o objetivo a ser realizado após a morte, mas como sendo um projeto histórico a ser realizado ainda no mundo dos vivos.

\footnotetext{
Parece-me que, nessa história de dezesseis anos em Crateús, o modelo de Igreja que emerge no interior da grande Igreja tradicional estaria tentando realizar, de modo muito limitado e imperfeito, a nova imagem, que é a velha imagem bíblica, proposta pelo Vaticano II. A Igreja é um POVO RESPONSÁVEL POR SUA HISTÓRIA DE IGREJA. No interior do povo, Deus suscita os MINISTROS para o serviço evangélico de todo o povo.

A CEB é vista por mim como uma verdadeira Igreja de base. Por isto, deve ser um povo co-responsável por sua história, no interior do qual estão os ministérios que são serviço evangélico ao conjunto. Não podem ser mais polos de liderança autoritária. (idem, p. 58)
}

Mas essa Igreja que se quer construir com os pobres, com o povo simples, é uma Igreja que não se conforma com a realidade do povo, não aceita a pobreza como destino dos homens e vontade de Deus. Para essa Igreja, o 
mundo é para ser compartilhado, sendo assim seu papel é alertar para as formas de exploração que existem e que evitam que todos possam ser beneficiados pela 'obra de Deus'. Da mesma maneira que a Igreja é uma obra coletiva, uma construção que não se faz por poucos nem é para poucos, ela não pode existir onde não exista a confraternização dos homens, afinal Jesus, $O$ filho de Deus, veio para redimir todos os homens.

$\mathrm{Na}$ realidade, a visão de Igreja assumida por D. Fragoso não se concentra apenas no religioso, mas extrapola esta dimensão em direção ao político. Várias vezes foi ele acusado de fazer política, mas como dissociar as duas dimensões principalmente numa religião como a Cristã que se assenta na crença de Cristo como filho de Deus, filho que nasceu pobre, entre os pobres, foi perseguido por subverter a ordem, prioriza a salvação dos pobres, por sua condição de pobre, de explorado, de oprimido, aos pobres cabe o paraíso, mas não um paraíso sobre-terreno, esse paraíso proposto deve ser construído desde já pelos homens e somente nesta construção estarão se qualificando para o paraíso eterno.

Segundo o padre Machado, em entrevista cedida ao autor:

Eu tenho a impressão que, pela forma como se conduziu o trabalho, eu acho que não havia por parte de D. Fragoso e os padres, a gente, não havia muito essa preocupação de formar o pessoal para a lgreja. Era para atuar no seu meio, para enfrentar as questões que lhes eram próprias. Então nesse sentido acho que a lgreja tomava as questões do povo como suas questões, eu acho que não muito essa separação sobre a situação da Igreja, sobre a estrutura da Igreja, hierarquia, quer dizer o foco não era esse, mas eram as questões do próprio povo. Então acho que estavam muito próximas essas realidades. O campo dos padres, a atuação nossa era muito isso o campo do povo, suas necessidades, suas preocupações. Não era para preparar gente para atuar na Igreja. (entrevista cedida em abril de 2011)

Não tem como não ser política a Igreja que a partir de D. Fragoso se constrói. Essa dimensão da religião apreendida por D. Fragoso ao longo de sua vida como homem de Igreja e como coordenador de um movimento de jovens que extrapolava a dimensão unicamente religiosa da Igreja Católica e 
propunha sua inserção no social organizando, conscientizando através da educação freiriana e da metodologia empregada pela Ação Católica Especializada, antes de Freire e creio que inspiradora da sua prática educativa, do ver, do julgar e do agir que faz com que cada um dos seus militantes se volte para a realidade e veja a condição dos mais pobres, dos explorados e dos oprimidos, que procure as razões humanas dessa pobreza, já que ela não é uma condição divina e que não pense na possibilidade de transformação da realidade que produz a pobreza.

Assim, respondendo aos críticos, àqueles que dizem que faz política, e ao mesmo tempo colocando a dimensão da política que a sua ação necessariamente leva a todos o que com sua ação estão comprometidos, diz D. Fragoso:

Mas creio que a Igreja tem a missão de animar com o Evangelho os projetos da sociedade existentes em Crateús. Cabe-lhe discernir, nestes projetos, a abertura ao Projeto de Deus; lembrar o horizonte que deve servir de elemento crítico na prática política, testemunhar $\mathrm{o}$ Evangelho em todo 0 processo.

Todo projeto político, todo projeto de sociedade, inevitavelmente, ou favorece a dignidade humana, sobretudo dos mais pobres, ou desrespeita o rosto humano dos filhos de Deus. Não há neutralidade. Compete à Igreja de Crateús, consequentemente, uma permanente vigilância crítica na análise de todos os projetos existentes. Procurará perceber em que medida estão contribuindo para que o povo realize sua vocação na história, veja seus direitos fundamentais respeitados e sua dignidade reconhecida, ou em que medida contribuem para a dominação e a marginalização opressora. (FRAGOSO. 1982, p. 79)

Essa visão de D. Fragoso, como ele mesmo diz antes do trecho acima citado, não pretende ser criadora de um partido político, de uma estratégia política, na linguagem dele, fazer isso seria utilizar a religião como portadora de uma visão, parcial, quando sua visão é totalizadora. Sua indicação contrária a condução por parte da Igreja da política

Seria clericalismo de tipo novo, que deve ser mais recusado do que o do passado. Antes era mais inconsciente. Hoje o nível de consciência da Igreja é incompatível com o clericalismo. Seria uma forma de teocracia. Estamos em 
tempo de secularização (autonomia legítima) e não da sacralização da política. Uma teocracia deve ser recusada porque Deus confiou à sociedade, e não a Igreja, conduzir de modo autônomo o processo de desenvolvimento da comunidade política. (idem, p. 79)

A Igreja para ele, anima os homens, ajuda a discernir o certo do errado a partir da compreensão de que o homem é um ser de dignidade, mas não pode definir um projeto, o projeto de sociedade deve ser dos homens. Sua presença entre os homens, estimulando a organização dos homens, deve está voltada para a compreensão da humanidade de cada um, da dignidade que essa condição de humanidade requer, independente do grau de religiosidade que cabe a cada um.

Para a Igreja de D. Fragoso, a característica básica é ser comunidade, comunidade que se compõe de tantas outras comunidades menores, até certo ponto autônomas, pois tem como base a comunidade geográfica, ou seja, ela é constituída por vizinhos, que vivem e comungam os mesmos problemas, que desejam atingir os mesmo objetivos construídos ao longo de um processo dialogal. Não há a imposição de objetivos, identificados os problemas, procuram-se as causas e se estabelece a forma de como superá-los coletivamente, ou através da ação direta ou através da pressão política sobre os poderes constituídos responsáveis por sua solução. Nesse processo, as pessoas se aproximam formando coletivos, independentemente da fé religiosa que professam, já que, o que se pretende construir em última análise é a solidariedade, o desprendimento e uma sociedade de iguais. Pessoas que se respeitam por se perceberem pessoas, dotadas de humanidade, e pela humanidade parte da comunidade maior, a comunidade dos homens.

Vista por essa ótica, parece-me que a fé, a religião ou o posicionamento político partidário não importa, importa sim construir uma comunidade humana inclusive com e em sua diversidade. A fé, a religião que a conforma, é apenas o chão em que ela se apóia e a liga que permite unificar interesses, na medida em que, através do diálogo, define os problemas, aponta as soluções e a maneira de superá-los. A palavra revelada se coloca 
como fundamento, pois indica o pertencimento a uma comunidade maior que é a comunidade humana, a história em que ela se insere é a história da humanidade, basta ver que o Deus feito homem, fez-se homem para unir todos os homens, independente de nacionalidade, de credo, de cor, de sexo; foi o cristianismo a primeira religião universal. Melhor, foi a primeira religião a objetivar a mudança social das estruturas de poder de modo a fundar uma nova sociabilidade.

Essa compreensão do cristianismo aparece de modo claro nas Comunidades Eclesiais de Base: ler a bíblia, ou ler a Palavra Revelada para desvelar o mundo e nesse desvelamento atuar sobre o mundo para melhorar a condição de vida do homem. Parece que, a partir dessa compreensão de religião professada por D. Fragoso, a condição primordial para a religiosidade seria o atuar sobre o mundo para melhorar a condição do ser homem, portanto o objetivo, mais do que o reino, ou por ele, era a melhoria nas condições de vida dos homens; torná-los, como diz Freire, mais humanos. Assim, as comunidades estavam organizadas para a vida em Igreja na medida em que se voltavam para o humano, para o mundo dos homens fazendo a história dirigir-se para a melhoria nas condições de vida de todos os homens.

Com isso, não se quer dizer que a preocupação com a Igreja como instituição que zela pelo sagrado não estivesse em pauta, claro que estava. Da mesma forma que procurava desconcentrar a riqueza, socializá-la, desta mesma maneira se procurava desconcentrar o sagrado, retirá-lo das mãos de poucos e transformá-lo em patrimônio comum, patrimônio de todos. $\mathrm{O}$ sagrado, a religião, era instrumento fundamental para a compreensão do mundo dentro de uma perspectiva diferente daquela professada, até então, pela Igreja tradicional. Se, como diz o próprio Fragoso, o papel central da hierarquia se devia à compreensão de que apenas ela era capaz de interpretar a palavra, se sendo assim, cabia a ela o papel de educadora, de reformadora dos costumes afinando-os com os interesses que nessa interpretação se revelavam, romper com esse centralismo era fundamental. A palavra era passível de tocar a todos os homens, que deveriam procurar 
no diálogo construído a partir dela a interpretação que se aproximasse dos interesses de todos. Nesse sentido, as CEBs assumem o magistério que, segundo Fragoso, não é prerrogativa da hierarquia. Afinal, "o Espírito se comunica com abundância ilimitada a todas as Igrejas Particulares, a todas as bases, sobretudo aos corações humildes e simples. Ele comunica e produz INTUIÇÕES sobre o Desígnio de Deus: intuições proféticas de leitura da história e dos acontecimentos." (FRAGOSO. ibidem, p.61)

Portanto, as CEBs são Igreja, são uma forma de vivenciar a Palavra na realidade, as paróquias e as capelas, esses espaços criados como lugar privilegiado onde a pessoa central é o padre e não o povo que escuta e segue, são secundarizados passando a centralidade do ser Igreja a todas as CEBs. Nelas todos são educadores, todos interpretam, todos, a partir da palavra e do diálogo convergem para os objetivos construídos por todos. Não há o retorno para casa, não há o viver individualmente a palavra, mas viver em vigília e viver coletivamente: a salvação só se dará se mediada pelo coletivo.

É uma virada e D. Fragoso aposta nela e no poder de convencimento que as CEBs têm como Igreja, não há distância entre os que compartilham da fé nas comunidades eclesiais, não há hierarquia, a fala é aberta para todos, todos se expressam a partir do seu lugar originando algo diferente, mas fruto da reflexão e da expressão de todos. Nessa situação todos crescem como humanos: com autonomia, com liberdade, com consciência da sua importância na construção do novo. As CEBs são espaços do fazer política na medida em que a política é o espaço da opinião e expressão de todos, é um espaço em que se constrói o consenso, mas um consenso que é dissídio, tomado-se o espaço da sociedade onde a fala, como na Igreja tradicional pertence, é privilégio de poucos, pois impõe a presença daqueles que não apareciam, que não falavam, que não contavam.

Gostaria de citar Pedro Ribeiro (1997) quando ele avalia as CEBs a partir da construção de uma Igreja viva: 
Concluindo, vemos na comparação entre os dois modelos que a originalidade da CEB reside no fato de trazer um novo padrão de relações entre as pessoas que, no papel de animadores e animadoras, assumem a direção pastoral de sua comunidade. Ainda que muitas CEBs aparentemente ocupem na instituição paroquial posição similar à das antigas capelas, é outra sua posição estrutural. As relações entre o pároco e a coordenação da comunidade são agora regidas por outro padrão: ao pároco cabe, certamente, zelar pelos laços de comunhão da CEB com a grande instituição eclesiástica católica, mas os animadores e animadoras de comunidade não são mais nomeados por ele como eram os zeladores e zeladoras das capelas. Isto porque, em vez de serem subdivisões pastorais facilitadoras das paróquias, as CEBs tornaram-se unidades básicas que reestruturam esvaziando o poder decisório da matriz e transformando-a em centro facilitador de serviços pastorais e administrativos às bases. (p. 135)

São duas formas de ser Igreja que se distinguem na medida em que concentram sua força em espaços institucionais diferentes. Na paróquia, 0 poder de decisão se encontra na hierarquia, na CEB, se encontra na comunidade. Essa diferença é responsável por uma dinâmica diferente. As decisões são compartilhadas igualmente por todos os membros, democratiza-se a Igreja e com ela democratiza-se a sociedade, já que essa forma de ser Igreja é encarnada, os homens que a fazem são pessoas que assumem na sociedade papéis diferentes, na medida em que compartilham suas vidas tornam essas vidas mais ricas contribuindo para o advento de mudanças em seu entorno.

D. Fragoso assume de tal maneira essa nova forma de ser lgreja que, segundo o Padre Eliésio, acabava por esquecer o seu papel de bispo e das prerrogativas que essa função institucional lhe garantia. Assim foi quando da eleição do Conselho Diocesano de Pastoral. Segundo Eliésio:

Em 1970 a Assembléia Diocesana de Pastoral elege um Conselho Diocesano de Pastoral composto exclusivamente de leigos. O bispo advertido pela assessoria sobre o inaudito da situação; um conselho pastoral sem padres reage dizendo que se sente escolhendo quando a diocese escolhe e com dificuldade usou seu direito de nomear um padre para o integrar atendendo assim as exigências dos cânones. (SANTOS. 1989, p. 4) 


\subsection{A História nas Mãos}

O título acima, apesar de batido, indica a visão de $\mathrm{D}$. Fragoso com relação à história. Para ele, a história é realizada pelos homens, fruto da práxis humana. Por isso era importante a educação, como educação libertadora e conscientizadora, por isso era importante a reunião dos homens em comunidades; as comunidades para ele eram espaços educativos e também espaços políticos, ou eram espaços políticos enquanto espaços educativos ou o contrário na medida em que o processo educativo que procurava inaugurar nas comunidades era aquele em que a educação se dava a partir da reflexão sobre a realidade, reflexão que era compartilhada por todos. Era freiriana como também era um reflexo do seu tempo de Ação Católica.

É interessante frisar que quando de sua chegada a Crateús, uma das suas ações foi entregar o colégio das freiras ao Estado, não estava interessado em uma educação formal que seguisse os manuais do governo federal ou estadual. Sua preocupação desde o início foi a educação como espaço político, espaço de libertação. Para que isso ocorresse era necessária a mediação da realidade, era a partir dela, da situação vivida, da reflexão a partir do vivido que se educava, mas esse processo educativo não se encerrava na reflexão, ele ia adiante, ele levava o homem a agir sobre essa realidade para modificá-la. Pode-se perceber que a educação não era um processo de acumulação de saberes, mas era um processo de descobrimento da situação do homem para modificá-la, situação que era vista como histórica, social, econômica, situação que indicava um tipo de produção e de relação de produção que era também relação de poder, era preciso romper com a realidade da maneira que ela estava posta.

Por isso a educação que inaugurava em Crateús era política e se constituía em educação política na medida em que descobria as relações de poder e as relações de dominação que dele decorriam. Combater essa forma de poder e de dominação era urgente para que os segmentos populares pudessem realizar sua humanidade. Uma Diocese que pensava assim não 
poderia continuar mantendo escolas que educavam para o conformismo, para a reprodução da dominação e, claro, não se poderia educar dentro dela a partir de outra perspectiva. Para ele, o foco da Diocese era uma educação libertadora, todos os conteúdos deveriam está voltados nessa direção.

A comunidade era o espaço educativo, era nela que o homem vivia, vivia com os outros homens, compartilhava com eles de um destino comum. Era no espaço da comunidade, e aqui ele revela que a comunidade era a comunidade dos pobres ou dos empobrecidos, que se deveria dá o processo de educação, pois era nela que se percebiam pobres e explorados. Essa não é uma percepção difícil de verificar na medida em que, no campo, o surgimento das comunidades rurais ocorre com a expulsão dos moradores dos limites do latifúndio; a modernização do latifúndio rompe as relações anteriores, de clientelismo, de apadrinhamento, que mantinha o agricultor, mesmo que nos limites mínimos de sobrevivência. Expulso, não dispunha mais da terra para cultivar o pouco que o mantinha e a sua família.

Essa percepção que se antevê na escrita de D. Fragoso, faz com que essas comunidades se tornem mais do que espaços de vida e se constituam em espaços educativos e, por isso mesmo, espaço político. Mas para saírem da situação de comunidades geográficas, caracterizada pela vizinhança, para saírem da percepção superficial de vítimas, mas que pela noção de propriedade de que eram detentores, eram vítimas pessoais dos interesses 'mesquinhos' dos proprietários, para saírem dessa visão que não aprofundava pondo a descoberto as causas mais profundas de sua atual marginalidade, era necessário que houvesse a interferência de fora que os convidassem para a reflexão sobre a sua situação presente, mas era necessário que a interferência de fora fosse confiável. A Igreja aparece e ela aparece porque como diz Fragoso "A FÉ SEM A PRÁTICA POLÍTICA É MORTA" (o Rosto de uma Igreja, 41)

A partir dessa perspectiva, começa um trabalho de base nas comunidades que procuram desvelar a realidade da opressão em que vivem os camponeses. $O$ interessante é que $D$. Fragoso afirma que não se tinha 
inicialmente uma visão clara do que fazer. Sabia apenas que a Igreja de Crateús seria uma Igreja libertadora, seria uma Igreja constituída de comunidades de base, Comunidades Eclesiais de Base:

Os dez anos de esforço contribuíram para uma certa unidade, uma certa pastoral de conjunto. Mas esta linha não nasceu por uma assimilação e conquista organizada das bases, por uma intuição e descoberta das bases, por uma reflexão sobre a prática pastoral das bases. Nasceu, sobretudo, da reflexão dos quadros paroquiais e diocesanos.

Neste trabalho, pouco a pouco, fomos descobrindo que a comunidade de base é mais do que comunidade de base. Ela é COMUNIDADE ECLESIAL DE BASE. Isto não foi descoberto, ao mesmo tempo, nem por todos. $\mathrm{E}$ ainda há muitas sombras, interrogações e mistérios em torno do assunto.

No entanto, de acordo com minha perspectiva, descobrimos que as comunidades de base são estes espaços de vizinhança geográfica, seja na periferia das cidades, seja no interior, onde as pessoas se relacionam solidariamente, sob muitas formas diferentes, sem ter consciência explícita disso. Visitam-se, ajudam-se, sabem quem nasceu, quem morreu, quem noivou, quem viajou para o sul, quem está voltando... São todos sinais de solidariedade comunitária. São comunidades de base em formação, sem consciência psicossocial elaborada. (idem, 37)

É um projeto em construção que se faz com a participação de todos. Há nesse empenho de construir algo novo que permita que a população das comunidades busque conquistar espaços na sociedade global, espaços políticos, ampliando os espaços da política que são as comunidades. Parece, nesse contexto, a realização da proposta de Arendt, as CEBs são espaços públicos do fazer política na medida em que nesses espaços as pessoas se encontram, falam das suas vidas, do trabalho, da moradia, das relações de vizinhanças, dos problemas que compartilham. Mais ainda, nesses espaços as concepções de vida se intercruzam, dialogam e afinam suas interpretações, ampliam o conhecimento da realidade e se organizam, a partir dos espaços da política, ou espaços que se tornam espaços da política, atuam, voltam enriquecidos para suas vidas comuns.

Freire pretendia com sua prática pedagógica, estabelecer o diálogo entre os educandos e o educador para ir paulatinamente ampliando e aprofundando a 
percepção de todos. Os círculos de cultura não eram nada mais do que desvelar a realidade a partir da palavra expressa, a palavra que diz alguma coisa sobre o real, nomeia uma realidade dada, indica para a reflexão do outro sobre o que se fala, objetiva. Com esse processo duas coisas acontecem: em primeiro lugar aprender a palavra, o nome, e depois apreender a realidade sobre a qual ela refere. Afinal, a palavra como o nome da coisa, não apenas indica o objeto, mas indica a relação, o objeto em si não existe, existe em relação. Mesa é mesa, um artefato humano construído a partir de relações determinadas em um dado momento histórico, feitas por homens concretos e envolve toda uma série de etapas e de relações que, ao ser colocado para os homens, os fazem perceber a complexidade da situação em que estão envolvidos.

Graciliano Ramos, em seu livro Vidas Secas, destaca a questão da palavra, do domínio da palavra, do mundo que ela abre, da riqueza, inclusive de sentimentos que ela proporciona. O seu personagem central indica toda a ansiedade daquele que não tem como dizer, e por não conseguir dizer, acaba por reagir da forma que sabe, usando a violência, violência que se perde, pois não tem objetivo. $O$ espaço do campesinato, principalmente no Nordeste Brasileiro, é o espaço da não-fala, do não ter o que dizer, pois não tem como dizer, as vidas são secas, seca inclemente provocada pela falta das chuvas, das terras, das condições de produção, mas, ainda mais, por faltar a palavra com a qual expressar a vida.

Para D. Fragoso era fundamental o processo educativo, principalmente um processo educativo que se dava no contexto de vida dos rurícolas, isto porque aprendia a realidade, mas não só aprendia a realidade, mas passava a ver a realidade que o circundava e a dizê-la, afinal sobre a realidade ele sabia, não sabia dizê-la nem mesmo para ele próprio e que isso sua ação se restringia, se limitava no espaço social, espaço que dizia apenas dos seus, mesmo assim, dizia muito pouco. Reuni-los, e com eles reunir a equipe diocesana, fazê-los dizer o pouco que sabiam, pois eram poucas as palavras, esse pouco ia ficando muito, e o mundo em toda sua complexidade ia se desnudando à sua frente. 
No interior delas, em torno da Palavra e por elas convocadas, nascem as pequenas Igreja vivas na base.

Na luz da Palavra, lêem, discutem, debatem, analisam a vida. Lendo a vida descobrem a miséria, que machuca a carne dos seus irmãos. "A Palavra de Deus Ihes põe no coração o amor de Deus que é Pai e que não pode aceitar, de maneira alguma, que a miséria machuque a carne de seus filhos. (FRAGOSO. 1982. P. 38)

Em torno da palavra, da palavra revelada, palavra que de qualquer maneira se refere à vida, vivida mesmo que em relação a Deus, que nesse caso é o outro, o outro que fala, mas que ao falar desvenda o mistério da vida; ilumina a vida, permite que sobre ela se apreenda mais. Mas é a palavra dita de outra maneira, não como era dita antes, apesar de ser a mesma palavra, ela aparece agora iluminada por outras tantas palavras trazida à baila por outras pessoas e por elas mesmas quando defrontada com a vida que cada um e todos levam, vivem. Reconhecer que a palavra dita, ou a Palavra Revelada, diz sobre o mundo é reconhecer que a palavra dita pode ser dita de maneira diferente por pessoas diferentes. Mas a palavra dita, objetiva, e a Igreja que a fala, o faz através da palavra revelada, porque ela é o contexto de compreensão da vida e quando ligada, não solta, mas encarnada como o quer a nova Igreja na vida de cada um e de todos, ela ganha nova riqueza, ela aponta novas realidades, desvela a realidade que está por trás da vida de todos.

A ação iniciada em Crateús por D. Fragoso inaugura uma nova forma de viver a religião, vivê-la a partir do real, da vida cotidiana de cada um e de todos. A Igreja trazida é uma Igreja que educa, revela, muda, transforma e o faz através do diálogo, aprendendo com a palavra, a dizer com a palavra, expressá-la objetivando a construção do novo. Tudo que foi dito a partir da prática pedagógica, do fazer história, história que é feita pelos homens, pelos homens comuns que se percebem capazes de mudar mudando, de organizar e pressionar, de apontar direitos e indicar a maneira desigual com que ele é aplicado. Não mais apenas o nome das coisas, mas também das relações que a partir das coisas se estabelecem as palavras, e com certeza 
a Palavra, revelam as condições de dominação e opressão a que estão submetidos.

Tivemos necessidade de provocar o salto crítico, que consiste no seguinte: a comunidade, lendo na luza da Palavra sua realidade, descobre, pouco a pouco, que a causa da miséria é humana, é sociológica. Se homens criaram a miséria, homens unidos em comunidade, tendo o Deus Vivo no meio como sua força, podem retirar as causas da miséria. Consequência: a luta contra a miséria, a nível da comunidade.

Mas nós fomos mais longe, na prática comunitária.

Descobrimos que a leitura da realidade com dois olhos - olhar da fé, iluminado pela Palavra de Deus e o olhar sócioanalítico, unindo ciência e experiência - nos revela que a miséria não só é causada pelos homens, mas que estes estão organizados em classe opressora. Contra a opressão organizada em classe, é necessária uma luta organizada dos oprimidos. (FRAGOSO. idem, p 38)

Como se pode verificar, à Palavra se une a palavra: Jesus e Marx, dois instrumentos fundamentais ${ }^{47}$ que ajudam a perceber a realidade na sua instância mais profunda ao mesmo tempo, que empurram para a ação política transformadora. D. Fragoso em seu relato mostra que se a comunidade é um espaço político que desvela a exploração em seus diversos níveis e revela que a pobreza decorre das relações que são assumidas pelos homens em determinado momento da história, que a miséria e suas causas não estão localizadas apenas no nível local, mas extrapola esse nível e revelam relações de poder e dominação que se reproduzem em todos os níveis. Portanto, é necessário muito mais que a comunidade. É necessário, também, que se inaugurem outras formas de organização que ampliem a ação das comunidades e que possam se dirigir a outros níveis de poder e opressão. A partir daí aparece a necessidade dos sindicatos e dos partidos políticos, instrumentos que irão permitir aos membros das comunidades atuarem no nível regional e nacional.

Assim expressa D. Fragoso:

\footnotetext{
47 "Não temos as portas fechadas para o instrumental científico de análise da sociedade capitalista, que Marx oferece, pelo fato de vir de Marx. ...” citação que se encontra na íntegra à página 122 deste trabalho.
} 
O nível de organização, para além das fronteiras das comunidades, é o sindicato. Ele une a categoria profissional dos trabalhadores rurais.

A CEB não conduz à luta sindical, não promove, não dirige a luta sindical. Não é a sua competência. Mas anima a consciência dos militantes sindicais, para que, movidos por sua Fé no interior de seu compromisso de classe, lutem com seus companheiros contra a opressão, na fidelidade ao Evangelho e ao povo do campo. (ibidem, p 38)

A compreensão de D. Fragoso, a compreensão que ele passa para os militantes de CEBs, é a de que a sociedade é dividida em classes sociais. É necessário, portanto, que os trabalhadores percebam essa realidade; existem classes e elas são oponentes, uma explora e vive da exploração enquanto a outra é explorada e oprimida. Da mesma maneira ele deixa claro que é necessário lutar, e a luta é fruto da organização da classe, é uma consequência da percepção de pertencimento da classe. Nesse sentido, ele aponta a direção da superação do momento da opressão a partir dessa luta de classes, lutar para transformar a sociedade numa sociedade sem classes. Mas para que essa luta resulte em mudança é necessário que os membros da comunidade encontrem formas de organização específicas, o sindicato é uma delas. As CEBs são espaços políticos de conscientização, de percepção da realidade, de comportamento das pessoas que a partir delas e animadas por elas irão atuar em outras frentes mais propícias à ação política transformadora.

É interessante que ele não comunga com a forma rede de comunidades, redes que assumiriam o papel político revolucionário. Para ele, esse papel deve ser assumido por outros instrumentos de organização e luta dos trabalhadores. As CEBs são espaços de conscientização, espaços políticos de compreensão da realidade e da urgência da mudança, mas são espaços locais, é necessário ir além e essa compreensão o povo das CEBs passa a descobrir e a estimular. A CEB é o espaço da luta inaugural, dela para outras instâncias, mas ela não morre, não fica apenas na condição de passo inicial, é permanente sua ação como permanente é a necessidade de mudar. 
A análise de D. Fragoso vai adiante, passa desse momento para uma análise mais aprofundada da luta de classes:

A LUTA DE CLASSES de que eu falo não tem conteúdo herdado de teorias científicas sobre a luta de classes. Refirome ao fato da experiência cotidiana: há mecanismos de exploração montados por pessoas que deles se beneficiam como classe dominante privilegiada. Há de outro lado, um imenso grupo unido pela miséria causada pelos opressores e tendente a se organizar em classe dos oprimidos.

A luta é causada e nutrida por aqueles que estão organizados em classe opressora. (idem, 39)

Para ele, a luta dos oprimidos é justificada pela forma como a produção se organiza, produzindo mais e mais oprimidos e explorados. A luta existe na realidade, ela não pode ser disfarçada ou escondida como pretendem as classes dominantes. Ele faz uma crítica às ideologias que se referem à sociedade como uma grande comunidade e que a luta de classes, a oposição existente entre elas, fosse introduzida por pessoas ou ideologia estranhas para perturbar a paz nacional. Esse era o discurso da ditadura militar que falava de uma índole nacional pacífica e que os comunistas incutiam no povo à revolta, quando não havia motivos para tal na medida em que somente através do desenvolvimento, desenvolvimento pretendido pelas elites, poderia levar a generalização do bem estar.

$A$ visão de D. Fragoso indica, contra o que afirmam os militares e seus ideólogos, que os pobres têm direito à organização e à luta contra a opressão. A luta dos pobres não é uma iniciativa dos pobres, mas uma reação dos pobres à exploração e à opressão a que são submetidos na ordem capitalista. Para ele haveria a possibilidade de outra (ou outras) forma de organização da produção e da sociedade, que fosse fruto da associação e dos interesses coletivos e não resultado da ganância de poucos. Assim, a luta dos pobres é a luta para a libertação de toda a humanidade, inclusive de libertar o opressor de sua condição de opressor. Os pobres não se organizavam para oprimir, mas para instituir uma sociedade sem classes: sem oprimidos e opressores. 
$\mathrm{Na}$ sua concepção de luta de classes, ele indica que as comunidades de base são espaço político de conscientização, de mobilização e animação dos trabalhadores, que existem instrumentos mais apropriados para a luta de classes em um nível mais amplo, o que revela sua compreensão de que a solução para a miséria não se encontra apenas no local e que não é provocada apenas pela exploração do proprietário da terra com relação ao seu trabalhador, mas é uma consequência de estruturas mais amplas e gerais que produzem e se reproduzem nas relações de produção locais, tais como os sindicatos dos trabalhadores. Fala também sobre o papel dos partidos políticos como instâncias de luta de classes, instância de universalização da luta de classes. Mesmo apresentando uma sequência gradativa, do mais simples para o mais complexo, sua visão não é empobrecedora, pois reconhece o papel das comunidades alimentando e elaborando a compreensão dos seus membros, do sindicato que se alimenta continuamente desse processo mais prático e concreto das comunidades até chegar ao partido. Todos eles se intercruzando no trabalho de educação conscientizadora e de militância política, todos eles elaborando uma nova visão de realidade que se constrói em todas essas instâncias modificando a práxis das pessoas continuadamente.

Sobre os partidos políticos e sua relação com as CEBs diz ele:

Prática política, nas CEBs, não é primeiro a prática políticopartidária. É primeiro uma busca organizada do Bem Comum, que é apenas, um direito e um grave dever evangélico para todos os cristãos. Nesse sentido, a luta política se organizam através das comunidades. Evidentemente, trata-se de um $A B C$, de uma escola primária, que deve continuar com outras expressões e movimentos que não estão diretamente vinculados às $\mathrm{CEBs}$. Mas, nas $\mathrm{CEBs,} \mathrm{os} \mathrm{militantes} \mathrm{cristãos}$ vêm nutrir sua esperança, clarear o olhar de sua Fé, exercitar a leitura de toda sua realidade na luz da Palavra, celebrar sua Paixão e sua Libertação com toda a Igreja.

Aqui se passa o desafio mais profundo e mais exigente: articulação permanente entre Fé e Prática política. (ibidem, 41)

D. Fragoso consegue compreender que a luta dos trabalhadores é um movimento que se faz e se organiza, enquanto se faz, a partir das várias 
instâncias da realidade, começando pelo mais concreto, os locais de moradia e de trabalho, para ir, na medida em que avança, e o seu avanço se dá na medida em que percebe as interações entre os níveis da realidade que vai do concreto ao abstrato, do singular ao universal, a partir de múltiplas leituras e abstrações do real subjetivadas e objetivadas através dos diálogos que se constroem nos contatos sociais. Sua ação é uma ação política, com uma opção clara pelos segmentos populares que sabe capazes de construir uma nova sociabilidade. Sua ação não vagueia nos limites do capitalismo, mas quer avançar para além do mesmo, para novas relações econômicas, sociais e políticas, para novas formas de sociabilidade assentadas em novas bases.

Analisando as ações de D. Fragoso, tanto pelo que escreveu, como pelo que escreveram sobre ele, que o bispo de Crateús tinha uma forma muito própria de ver a lgreja e de ver sua inserção na sociedade, afinal, como já citei em página anterior, para ele a Fé sem a Política não existe. Para ele, a Igreja somente se justificava pela ação transformadora, que a Igreja era povo, e povo se insurgida contra a ordem, quando capaz de atuar revolucionando as relações entre os homens, em direção a uma vida plena. 


\section{CAPÍTULO IV}

\section{AS COMUNIDADES ECLESIAIS DE BASE E A POLÍTICA EM CRATEÚS}

A Diocese de Crateús foi criada em 1964. Até então o município de Crateús e oito dos municípios que passaram a compor a nova Diocese pertenciam a Diocese de Sobral, Diocese criada em 1914. Em 1964, a Diocese de Sobral tinha um perfil diocesano que não desviava dos demais. Vendo o que $D$. Fragoso fala a respeito de $\mathrm{D}$. José Tupinambá da Frota, bispo da Diocese de Sobral por mais de quarenta anos, e citado em capítulo anterior, como o bispo que constrói civilização, que faz colégios, seminários, que atua na sociedade como ativador do processo de desenvolvimento, como formador de personalidades conformadas com o modelo de sociedade que se tem e com um modelo de Igreja hierarquizada, reproduzindo a estrutura social de então, pode-se perceber o impacto que causou a nomeação de D. Fragoso para a nova Diocese de Crateús.

A história de D. Fragoso, história que antecedeu a sua chegada revelando sua participação ativa na Ação Católica Especializada, principalmente a Juventude Operária Católica, de alguma maneira definia o tipo de Igreja que poderia instalar em Crateús. A resposta que deu às autoridades, na recepção que Ihe foi feita pelas lideranças de Crateús, confirmara que o bispo que chegava tinha outra postura. Sua ação pastoral, como ele mesmo expressou, era dirigida para os pobres e com os pobres. Não seria uma consequência da sua vontade até porque a Igreja que pretendia inaugurar deveria ser participativa, aberta aos leigos, protagonizada por eles.

Para que essa Igreja pudesse assumir essa nova postura era necessário que o bispo diocesano conhecesse a realidade local, conhecesse o povo, sua origem, seus problemas, suas necessidades. Era necessário que abrisse canais de comunicação com os pobres, com os trabalhadores, com a realidade que envolvia essa população, que em sua maioria era rural. Assim, 
segundo declaração do Padre Elênio, D. Fragoso procura conversar com os padres, saber sobre a realidade do povo, sobre a Igreja, suas práticas, queria saber sobre o terreno que pisava. Depois, procura organizar semanas catequéticas para um contato com o povo já que a catequese era feita por leigos, leigos intimamente ligados as comunidades em que atuavam.

Nesse processo de aproximação com o povo, ele, segundo vários depoimentos, costumava visitar as paróquias, visitar as vilas rurais, visitar as pessoas em seus locais de moradia. D. Fragoso, segundo ainda os depoimentos que consegui obter com padres e lideranças sindicais, ao conversar com as pessoas se colocava muito mais na posição de escutar do que falar, dizer o que pensava, na realidade o que queria era ouvir o outro e, ao ouvir, saber como tocá-lo, saber como convencê-lo do projeto de Igreja que trazia de sua experiência no Maranhão e de sua participação no Concílio Vaticano II.

Suas declarações em entrevistas cedidas ao padre Alder Júlio, mostram que D. Fragoso era uma pessoa que sabia o que fazia, tinha uma visão de Igreja e de Mundo que se diferenciava da visão dos outros, mas era uma visão que somente poderia significar se posta para os outros, se incorporada pelos demais, se completada pela visão dos outros religiosos e leigos com os quais poderia e compartilhava dessa visão. Não era uma pessoa que deixava as coisas acontecerem. Sua prática era pensada, calculada, daí sua inserção apontar sempre numa mesma direção: um Igreja feita por todos, voltada para as necessidades do povo.

Há uma tendência em Crateús, principalmente daqueles que acompanharam a caminhada de $D$. Fragoso, de minimizar sua presença, de minimizar sua ação e seus compromissos, compromissos que ele trazia e que apenas consolidou e concretizou em Crateús. Para o Padre Elênio, em entrevista cedida a este autor:

Eu não sei se havia tanta essa preocupação de fazer uma igreja nova, mas procurava conhecer a realidade do povo e trabalhar um pouco essa realidade. Por exemplo, começaram 
as organizações do próprio povo sem se falar em comunidades, não se sabia nem o que era isso. A palavra mais usada naquela época era o sindicato, agora ao lado dos sindicatos as comunidades iam se organizando, tanto assim que os trabalhadores do campo, e todos eram trabalhadores do campo, começaram a se reunir mais, a perguntar, a querer saber das coisas. Aí, então a gente começou a dar uma feição à igreja, foi assim que começou.

Não sei se, ao minimizar, o padre Elênio queria por em relevo o protagonismo do povo. Para ele, como aparece na entrevista, o povo ia fazendo sua caminhada e, ao fazê-la, constituía as novas estruturas que davam sustentação e consolidavam o jeito novo de ser lgreja. Para D. Fragoso, a caminhada se faz assim: ele tinha uma visão de Igreja, mas não era apenas pegar sua idéia e pô-la em prática, instituí-la, era necessário que as pessoas com as quais caminhavam a incorporassem e a incorporassem a partir de sua realidade, de sua forma de ser, de agir e de atuar. Assim, ele irá dizer que "um projeto só se torna prática popular transformadora (se) as pessoas o assumem, o entendem e o põem em prática." (FRAGOSO. 2007, p. 44)

Pensando uma Igreja feita por todos e querendo-a implantar de fato, D. Fragoso procura em que se apoiar, afinal para que aconteça a adesão do povo é necessário que ele consiga perceber no novo algo que se aproxime dele, que ele reconheça, que saiba a direção, onde vai dar. Não há como o povo assumir uma aventura, não há como assumir posições com estranhos, com desconhecidos. D. Fragoso percebe a dificuldade que teria em função daquilo que a seu respeito seria dito por pessoas que são da intimidade do povo de Crateús. Sobre isso diz D. Fragoso:

[...] Mas, a perseguição em Crateús começou sobretudo do conflito entre a visão dos dois vigários que passaram cinquenta anos por lá: Pe. Juvêncio e Mons. José Bonfim, que ensinaram ao povo o catecismo, a religião, a prática da religião... Mas não queriam que o povo desse opinião, tinham que ficar de bico calado, sobretudo os pobres. Os pobres são para a gente ter pena deles. Não devem ter nenhuma função na Igreja. Então, diante dessa Comissão (sic) que eu encontrei, é lógico que da parte da Igreja estava dividida: para a parte dos cristãos de classe média e de classe alta e os 
cristãos, o povo mais piedoso, formado naquilo que foi pregado pelos missionários do passado, eu era um hereje. Em vez de hereje eles diziam subversivo, por não está seguindo o que a própria Igreja manda, por ser um inimigo da Igreja verdadeira. (FRAGOSO. 2007, p. 36)

Mas, ao mesmo tempo sabia que a catequese, que era feita por leigos, não contava com a presença dos padres. Os catequistas tinham certa autonomia, o que facilitava seu trabalho gerando o que poderia ser uma adesão a sua proposta de Igreja. Da mesma maneira, ele contava com a presença de jovens que, orientados pelo padre Antônio ${ }^{48}$, tinha uma inserção mais ativa e mais voltada para as necessidades do povo. São esses jovens que irão de alguma maneira respaldar sua ação, não apenas respaldar, mas garantir sua validade. Segundo D. Nenen:

Pra mim, foi esse grupo que apoiou, foi a raiz, depois que D. Fragoso chegou, criou associações, mais foi criada já com aquele grupo que ajudava, já fazia o trabalho comunitário. Aquele grupinho começou a crescer naquele bairro, mas quando D. Fragoso chegou ainda não havia a associação, só tinha a frente social cristã foi criada em 1963. Em 1964 D. Fragoso chegou, já tinha a Frente Social Cristã que era um grupo que o padre Irismar acompanhava nos bairros, ele tinha um trabalho em todos os bairros.

Assim D. Fragoso começa seu trabalho em Crateús, contanto com as catequistas e com alguns padres que tiveram sua formação em outros países, como era o caso de Padre Irismar. Mas não se poderia negar a importância que os jovens da JEC, da Casa Betânia e das Luizas de Marilac tiveram no primeiro momento. Eles eram pessoas da cidade, pessoas que realizavam, com o padre Irismar, ações nos bairros, entre os mais pobres, como a reconstrução de moradias. O próprio D. Fragoso faz referência a esse trabalho ao dizer:

\footnotetext{
${ }^{48}$ D. Fragoso faz referência ao padre Antonio. Acredito, no entanto, que esse padre Antonio é o padre Irismar, pois ele, segundo depoimento das entrevistadas Ivânia, D. Nenen e Rosali, foi o padre Irismar que começou com ações entre os jovens de Cratéus. Segundo Ivania, o Padre Irismar teve sua formação em Roma: "O padre Irismar era daqui, mas ele foi formado em Roma [...] trabalho de grupo com método de construir, porque era através daquele método que vinha uma consciência política da situação" (entrevista cedida ao autor)
} 
E ele começou a contar com os idosos, com os anciãos. Começou a reunir jovens para se divertir, para brincar, para estudar a religião, para dançar, se encontrar, fazer amizade, e muito exercícios desse jovens eram irem, aos domingos, às áreas onde havia os mais pobrezinhos, que não podiam lavar sua roupa ou cuidar da comida, iam ajudá-los a fazer as casinhas - eles não tinham casinhas - faziam de taipa, mas faziam $^{49}$. ( idem, p. 50)

Mas, devemos considerar que a realidade do homem do campo, em Crateús e cidades vizinhas, era difícil. Ele estava submetido aos proprietários de terra, através da renda, e na medida em que seus direitos foram consolidados, os proprietários acabaram por afastá-los da terra, expulsá-los. A esse respeito, sobre a submissão do homem do campo aos latifundiários, D. Fragoso se refere inclusive acentuando as condições em que esse homem vivia nas terras dos proprietários das terras dessa região. Sua análise não fica distante da análise abalizada de Paula Joca (1993, p. 47)

Quando pensamos na agricultura do Ceará, vem logo à nossa já tão marcada lembrança, o sertão do algodão mocó, do parceiro-morador e do proprietário latifundiário. Esse foi, por muito tempo, o quadro dominante, ou melhor, o sistema produtivo dominante, calcado na cultura comercial do algodão e na pecuária bovina, como as principais atividades agropecuárias do Estado. Até a década de setenta esse sistema se mantém e se reproduz sem conhecer nenhuma ruptura significativa [...] É somente a partir dos anos de 1960, particular e intensamente nos anos de 1970, que o sistema começa a conhecer algumas rupturas internas e que tem início a sua desestruturação.

Os anos de 1960 foram palco de alguns acontecimentos importantes que vieram influir sobremaneira nessa mudança de rumos. Em primeiro lugar os trabalhadores vindos de suas primeiras experiências organizativas em associações e sindicatos demonstravam a disposição de se apropriar da legislação que acabara de ser aprovada: o Estatuto do Trabalhador Rural. [...] Decerto a apropriação que os

\footnotetext{
49 Confirmando que o Padre Irismar e o padre Antonio são a mesma pessoa basta ver o trecho da entrevista de Rosali que reproduzo: "Betania era uma casa que reunia jovens, mulheres e homens, tanto para formação como para lazer. Tinha jogos, passeios e reuniões. Era nessa casa que se reuniam as Luizas de Marilac que eram uma associação que visitava os pobres nos bairros mais pobres. Cada bairro tinha uma equipe que visitava os idosos mais carentes, levavam alimentos, faziam visitas , conversavam, viam o que estava faltando naquela casa." (entrevista cedida em 2011)
} 
trabalhadores começavam a fazer dessa legislação preocupou muito mais os proprietários de terra.

Essa situação assusta os proprietários principalmente porque, nessa época, aparecem vários mecanismos que possibilitam a concentração da terra e com ela a concentração de recursos financeiros. O Estado Militar incentiva a modernização da produção agropecuária como uma forma de se articular com os mercados externos e assim obter as divisas necessárias ao processo de industrialização que pretende. Era o tempo do Brasil grande, do Brasil moderno. O que segundo Paula Joca teria provocado a expulsão do homem do campo: moradores, parceiros e posseiros.

Transformadas ou não em empresas rurais, o fato é que as grandes propriedades, particularmente aquelas que abrigavam os parceiros-moradores, responsáveis pelo cultivo do principal produto agrícola do Estado, o algodão arbóreo, começaram letamente a experimentar mudanças nas relações de trabalho, que seguiram o percurso inicial de desenraizamento do parceiro. Esse desenraizamento passava pela preocupação do proprietário de 'entregar a semente' ou o 'terreno plantado', na tentativa de descaracterizar o 'bem de raiz' que o algodão mocó garantia ao parceiro, possibilitandoIhe vínculo maior com a terra e direito à indenização pelas benfeitorias implantadas na propriedade. (idem. p.48)

Essa percepção era presente entre os padres que com D. Fragoso atuavam na área da Diocese de Crateús. Sobre o assunto nos fala Padre Maurízio:

No momento em que chego em Parambu nessa época era uma área de fronteira, não somente porque limita com o Piauí, mas que a expansão do agronegócio estava atingindo aquela região com a expansão do plantio de caju e no final da invasão da produção de óleo da Brasil Oiticica e de coisas assim que estavam ocupando a área da Serra com limite entre o Ceará e o Piauí e retirando os posseiros que há séculos estavam morando lá, uma área de conflitos, bastantes, uma área de conflitos de terra numa situação bastante aguda, e tempo também de reconquista dos sindicatos depois de um tempo, assim, mais ligados ao problema assistencial do FUNRURAL. Há uma militância mais explícita de assumir a luta pela renda, direito as raízes, era o tempo que 0 algodão era uma fonte de renda significativa e que 
os moradores estavam sendo expulsos para o patrão reconquistar o domínio sobre a terra que era colocado em risco pelo crescimento dos direitos dos trabalhadores que tinha raízes de algodão, do algodão mocó, que tinha uma vida de dez ou doze anos. Então, às vezes o valor das raízes era maior do que o valor da terra e diante da ameaça do patrão de expulsar os trabalhadores para que liberasse a terra o trabalhador começava a dizer: bom eu fico com as raízes e você fica com sua terra e pode tirálas com minhas raízes (?), um comércio de consciência (sic), mas também baseado numa realidade de uma relação mais complexa entre quem é proprietário do patrimônio imobiliário e que foi construído com trabalho, com direito real que iam se confrontando. Então o conjunto dessa tentativa de ocupação da terra por parte da indústria do caju, da indústria da oiticica, e a tentativa de expulsar o morador para poder libertar a terra e ela poder também ser colocada no Banco, poder ser comercializada, vendida, entrar no mercado de terras era o tempo em que cheguei em Parambu. As comunidades nesse momento viviam essa situação social, econômica, política, respirando no ar e vivendo suas consequências.

A percepção do Padre aparece ao longo da convivência com os camponeses que viviam em Parambu, área que, segundo Beserra ${ }^{50}$, era há muito disputada entre posseiros e latifundiários. Para ser preciso, a autora acima nomeada fala dos anos de 1930. Aliás, Parambu fica situada em área da Serra da Ibiapaba, disputada desde o século XIX por latifundiários cearenses e piauienses. Na medida em que os interesses dos grandes latifundiários aumentavam fomentados pela expansão da fronteira agrícola, pela valorização das terras a partir da construção de rodovias estaduais e federais, mais se sentiam ameaçados os posseiros que viviam secularmente na região.

Esse era um espaço de resistência e de luta que antecedia a criação da Diocese e a vinda de D. Fragoso com sua nova maneira de ser e viver a

\footnotetext{
50 Beserra dirá: "Mas nem só da luta dos moradores-parceiros sobrevive o movimento dos trabalhadores rurais. A luta dos posseiros pela sua permanência na terra também aglutinará contingentes significativos de trabalhadores em torno do movimento mais amplo pela Reforma Agrária. No Ceará, o movimento dos posseiros tem na luta dos posseiros de Parambu um dos seus mais fortes marcos." (BESERRA. Movimentos Sociais no Campo do Ceará. 1990, p. 82) Depois ela reproduz o relato histórico de Castelo Branco que começa com a sesmaria doada aos jesuítas e termina nas lutas dos anos oitenta do século passado.
} 
Igreja. Essas questões de alguma maneira se sobrepunham a forma antiga de ser Igreja a qual estavam conformadas as populações rurais da região de Crateús. São as situações descritas acima, a existência de um trabalho pastoral entre os jovens, o processo de expulsão do homem do campo em função da legislação fundiária aprovada na década de 1960 e as questões de terra que opunham posseiros e latifundiários, que facilitam, ou possibilitam, o trabalho de D. Fragoso, principalmente porque ele enfrenta essas questões e estimula, a partir delas, a criação das Comunidades Eclesiais de Base e dos sindicatos dos trabalhadores rurais.

\subsection{As Comunidades Eclesiais de Base}

Começo falando das Comunidades Eclesiais de Base reproduzindo trecho de Sader que diz:

Se observarmos os movimentos sociais que dão nova configuração social aos trabalhadores no cenário público na segunda metade dos anos setenta, nós nos damos conta da existência de novos significados atribuídos às suas condições de vida, e esses novos sentidos nem se desprendem 'naturalmente' do cotidiano popular e nem decorrem dos discursos previamente instituídos pelos trabalhadores. Eles constituem reelaborações filtradas em novas matrizes discursivas - quer dizer: novos lugares, onde se constituem diversamente os atores, estabelecem novas relações entre si e com o meio, e, portanto, abordam diversamente a realidade. (SADER. 1995, p.143)

A análise de Sader nos ajuda a entender a maneira nova como se organizam os trabalhadores do campo nos municípios que fazem parte da Diocese de Crateús. Para mim, a forma como as CEBs se instituem, revela um deslocamento do lugar, apesar de ser o mesmo lugar (o campo e as relações que nele se estabelecem secularmente), a perspectiva que emerge a partir da CEBs é outra, não é a mesma que emerge dos sindicatos e dos partidos políticos. Difere, em primeiro lugar, por sua ligação com a Igreja Católica, por serem comunidades que se organizam a partir do espaço em que seus membros vivem e sentem, coletivamente, compartilhando cada acontecimento. Quando se referem aos proprietários latifundiários, não se 
referem a uma abstração, quando falam em união de todos, esses não são sombras sem rosto ou feições, são pessoas concretas que como eles sofrem a opressão concreta do latifundiário.

Exemplo dessa situação é a luta dos posseiros da Serra da Ibiapaba contra os latifundiários piauienses e cearenses. Sua luta é pela permanência na sua terra, na terra da qual, como fala Martins, retira os produtos de que necessita para sobreviver com sua família. Sua luta é concreta e eles a compreendem assim. O Padre Maurízio, em sua entrevista, esclarece contrapondo à luta do MST, para os trabalhadores de Parambu a ocupação de terras era absurda, jamais eles se envolveriam em tal peleja:

Mas nas comunidades do interior onde cada animador era um que transmitia essa sensibilidade, essa abertura, essa linha de trabalho, de, a palavra de Deus deve levar uma mudança da vida real de entrar via a renda de trabalho com o patrão, renda que a gente está pagando, os dias cativos que não são considerados, o jeito de pagar a renda, a propriedade da terra, o direito de serem reconhecidos como posseiros, então de não pagar a renda, essas várias formas de lutar pela terra que foram experimentadas na diocese, considerava a capacidade de se adaptar a cada situação e encontrar respostas a partir da consciência que, dos direitos que os trabalhadores têm. Não se tratava de invadir a terra dos outros, se tratava de defender os direitos que o trabalhador tinha. Então vamos dizer assim: até respeito a perspectiva que depois o MST, ia (...) de invadir as cercas e serem os invasores de terra, foi uma construção também, a compreensão que os trabalhadores tinham na região quando eu cheguei é que o invasor era a empresa que vinha desalojar e retirar quem estava trabalhando na terra, quem tinha direito a terra, então o invasor da terra era o que chegou com seus cachorros, o invasor da terra era o produtor de algodão, da oiticica, é a indústria que está chegando e retirando do lugar onde a gente sempre morou e sempre viveu. Tanto que a liderança sindical daquele tempo meio carismática, que era o Cícero ... lá de Parambu, ele tinha como palavra de ordem: nós não precisamos ocupar terra, nós devemos deixar de pagar renda, nós já estamos na terra. Não era qualquer terra que eles estavam querendo, era poder viver na terra onde eles estavam, sem reconhecer a opressão do patrão. Então, digo, num certo sentido mais radical ainda de que a atitude de acampar para ganhar um pedaço de terra, a reconquista da dignidade do sujeito da prioridade da história camponesa com respeito a invasão de qualquer jeito é sempre colonial, que nunca foi assim bem administrada, com mudanças sucessivas (...) em certos casos continuam oprimindo as populações dos 
povos indígenas originários, acho que um pouco dentro dessa perspectiva também que a gente deveria reler que é que aconteceu com as comunidades como lugar que as pessoas reconheceram a sua identidade, a sua história, seus direitos, então se libertaram, eram cegos começam a ver.

A comunidade se estrutura, constrói-se a partir da realidade vivida; é a situação local que define a aproximação, que estabelece os laços que os aproxima. Não há como conseguir a organização dessa população rural sem que expressem o seu modo de ser e viver. Esse é o mérito das Comunidades Eclesiais de Base, sua luta por direitos, direitos daqueles que estão naquele lugar, são direitos negados lá, no lugar em que vivem. A análise do Padre Maurízio acentua este aspecto da mesma maneira que a análise de Beserra, a luta que se desenvolve na Serra da Ibiapaba é uma luta secular pelo direito à terra, terra que não era reclamada, somente depois se tornou importante para o latifundiário que viu, na expansão da fronteira agrícola, na construção de vias a ligar os grandes centros produtores com os consumidores, na valorização dessas terras a possibilidade de acumular capital, fazer crescer seu pecúlio.

Para eles, segundo a interpretação do padre, uma luta que questionasse a propriedade da terra, que questionasse a posse e sua aquisição fosse fruto da invasão, o próprio termo é por si só antipático contrário aos interesses dos posseiros dessa região, não poderia ter a simpatia de nenhum deles. Martins, inclusive, avalia o deslocamento provocado pelo MST, da luta pelo reconhecimento da posse para a luta pela ocupação do latifúndio, como responsável pela diminuição do apoio do público às lutas camponesas. A luta pelo reconhecimento da posse era a luta pelo reconhecimento de um direito, o direito de propriedade que tinha aquele que trabalhava na terra. $\mathrm{A}$ luta pela ocupação era, no entanto, a luta contra o direito de propriedade, contra o direito que tinha aquele que 'trabalhou' para conseguir a propriedade. Aliás, ele, como o posseiro, já estava lá.

A Igreja Católica, ao voltar-se para os trabalhadores e voltar-se para ele a partir de seu próprio espaço, espaço de vida, espaço de direito, direito 
reconhecido pelos trabalhadores como seu, pode transformar as comunidades, como diz D. Fragoso (2007), as comunidades sociológicas em comunidades eclesiais, e nesse processo as transforma em comunidades políticas. Mas, apenas por se colocar na perspectiva do homem dos segmentos populares, na perspectiva daquele que se reconhece senhor de direitos, direitos que Ihes foram retirados, sofreu, portanto, uma injustiça. A Igreja penetra em seu meio apenas por reconhecer, concretamente, os direitos que foram retirados, dos populares, pelos segmentos dominantes.

Essa característica das comunidades eclesiais de serem comunidades políticas é reconhecida por D. Fragoso, expressada por ele em seu livro $O$ Rosto de Uma Igreja. Para ele não há como lutar por justiça sem que se lute no espaço de vida, na sociedade política, referindo-se ao Estado e ao governo. Se Jesus veio para restabelecer o direito, a justiça entre os homens, nada mais natural do que a Igreja organizar esses homens em seus espaços de vida.

Sobre a questão, opina Frei Beto:

Grupos de natureza religiosa, as comunidades têm um caráter pastoral, que é aristotelicamente político. Por adotarem um método que parte da realidade, elas suprimem a dualidade févida encontrada em grupos cristãos que partem da doutrina e reduzem o 'ser cristão' ao domínio intelectual-moral das verdades reveladas e explicitadas pelo magistério eclesiástico. (1984, p. 31).

Mais adiante, dirá ainda Beto:

Como forma de organização daqueles que, por sua pobreza e opressão, revelam o verdadeiro caráter da polis, as comunidades permitem a Igreja retomar sua índole evangélica: ser fermento na massa, luz no mundo, sal na comida. Espaço de expressão da palavra do oprimido, nas comunidades emerge a consciência crítica do povo, à crítica à ordem social injusta. Nesse sentido, elas são políticas, não enquanto grupos partidários ou dotados de estratégias e táticas políticas. (idem, p. 31) 
O político-partidário, o sindical, não tinham sentido para as bases populares, para eles a discussão que eles encetavam era por demais abstratas, não expressavam diretamente sua realidade como as CEBs o faziam. Mas, por outro lado, a luta de cada uma das comunidades não tinha força suficiente para mudar as estruturas que garantiam o direito, mas não garantia sua efetivação. D. Fragoso entendia a necessidade de avançar na forma de organização. Era necessário o sindicato, e ele era necessário para ampliar as lutas, garantir respaldo, ampliar apoios. Enquanto não se efetivava o sindicato, as CEBs eram os espaços da política em um momento em que partidos e sindicatos eram cerceados em suas liberdades e finalidades: canais de expressão e ação dos segmentos sociais presentes na sociedade política.

Interessante é avaliar a análise de D. Fragoso na entrevista cedida a João Fragoso, seu irmão e também padre. Para ele as CEBs não podem conviver com a ditadura, há uma contradição que impede sua sobrevivência em regimes de exerção. Assim,

[...] Não é possível haver uma CEB onde houver uma Doutrina de Segurança Nacional, e onde houver uma Igreja também (o texto informa que essa palavra na foi entendida), é totalmente impossível. Então nesse sentido começou a repressão de todos os modos, a repressão porque o Espírito Santo conduz a caminhada das CEBs, por causa disso se estreita a expansão, a dimensão das CEBs, mas há uma purificação, há um amadurecimento, há uma descoberta nova e mostra também que as Comunidades Eclesiais de Base, nessa estrutura formal que tiveram aqui não eram definitivas, era talvez uma passagem, e pela mediação do Espírito gera outras formas mais perfeitas ainda de ser Javé libertador que caminha com seu povo para a Terra Prometida. (Fragoso. 2007, p.93)

Essa análise que D. Fragoso faz da incompatibilidade das Comunidades Eclesiais de Base com o regime ditatorial, pode ser verdadeira, afinal são duas coisas opostas, contraditórias, uma democrática em sua essência enquanto a outra impede a liberdade de expressão da palavra. Mas, foi durante a ditadura que as CEBs surgiram e se multiplicaram em todo o Brasil. Para mim, as CEBs foram espaços de liberdade privilegiados e que 
não poderiam ter surgido em outro momento, até poderia, mas não vejo como sobreviver em meio à democracia com seu localismo e basismo. D. Fragoso inclusive se refere às CEBs como um espaço primeiro para formas mais aprimoradas de praticar a fé e o fazer política.

Mas, somente elas poderiam ter existido como espaço da política nos anos da ditadura. Em primeiro lugar, em que pese as acusações que D. Fragoso sofreu ao longo do tempo, era tido como comunista, as CEBs eram organismos da Igreja que apoiou, num primeiro momento, o golpe dado pelos militares em 1964. Depois, eram organismos locais, não repercutiam fora daqueles espaços, suas lutas levavam apenas as questões mais concretas e mais específicas dos trabalhadores. Por fim, lutavam por direitos, direitos instituídos e legais mesmo nos marcos da ditadura, apenas não eram efetivados por contrariar interesses das elites fundiárias. Mesmo nos grandes centros, as lutas levadas a efeito pelas CEBs eram lutas circunscritas aos bairros e que, inicialmente, tinham do outro lado o Estado em sua expressão local.

Não ameaçavam, segundo os militares no poder. Tornam-se ameaçadoras apenas quando, através da Igreja, suas lutas são ampliadas, seus pleitos são levados a outros recantos, escapando do localismo inicial. Em Crateús, espaço de lutas, havia, como já foi analisado aqui, os posseiros, os moradores-parceiros e o Batalhão de Engenharia. Este era uma presença que fazia mais sentido ao autoritarismo, a prepotência das elites, a ausência da democracia. São questões como essas que tornam possível a existência de um foco do PC do B. A presença do filho de Pedro Pomar, a sua relação com D. Fragoso, a adesão de camponeses a esse núcleo comunista são, sem dúvida, um motivo a mais para a repressão se tornar mais sufocante.

Nas entrevistas cedidas por D. Fragoso ao seu irmão ele relata os momentos mais difíceis da sua relação com os militares. As denúncias sobre o seu trabalho como trabalho mais político do que religioso, a prisão e expulsão de padres, seus auxiliares, no processo de organização das CEBs, 
os interrogatórios a que ele e trabalhadores membros das Comunidades foram submetidos, essas são situações que de alguma maneira estabelecia limites a sua ação, mas ao mesmo tempo indicavam que apenas essa forma de organização e atuação política era possível.

Gostaria de acentuar que mesmo com as perseguições, mesmo com as prisões e expulsões a que são submetidos os padres, as religiosas e os militantes de CEBs, mesmo com os interrogatórios a que é submetido o bispo diocesano, mesmo assim as CEBs continuam com suas atividades políticas, com as discussões, com seus membros participando de manifestações, manifestações como as que ocorreram em 1970, com a seca. Esse espírito de luta descrito pelos entrevistados, analisados pelos assessores e coordenadores, por parte daqueles que acompanhavam 0 trabalho das Comunidades, impressiona quem se volta para o estudo das comunidades de Base.

Os riscos eram muitos, mas a disposição dos camponeses e dos religiosos que os acompanhavam era também muito grande. Talvez essa reação, essa disposição de luta se justificasse no fato das comunidades serem coletivos, não era um, eram muitos e isso, o fato de cada um saber da situação em que se encontrava o outro, era um fator de segurança: se a repressão fosse mais violenta do que o aceitável, os demais denunciariam, afinal as CEBs constituíam uma rede nacional e internacional interligada pela Igreja.

Padre Eliésio, em entrevista já citada, deixa claro que D. Fragoso mantinha contatos internacionais e esses contatos, muito deles, estavam em países centrais como a França, a Itália, os Estados Unidos. A repressão sobre ele, a repressão sobre as comunidades de base, repercutiam e organismos internacionais cuidavam para que a repercussão assumisse uma feição inaceitável. Os países citados acima se apresentavam mundialmente como democratas e defensores das democracias, não poderiam deixar que o apoio que davam as ditaduras latino-americanas prejudicasse suas imagens. 
D. Fragoso ${ }^{51}$ tem clareza disso e mantém os contatos internacionais inclusive procurando pessoas chaves, pessoas que pudessem contribuir com recursos financeiros ou pessoais. Segundo Padre Maurízio, na entrevista já citada, foi assim que D. Fragoso trouxe para Crateús pessoas que tinham experiência em trabalho de base, na organização sindical e política dos trabalhadores. Fazer o que foi feito em Crateús demandava pessoas com qualificação e disponibilidade para 0 trabalho com os segmentos populares. Era necessário, inclusive, que fossem capazes de defender a proposta de organização dos trabalhadores e da Igreja a partir das Comunidades de Base. D. Fragoso estava bem assessorado, mas não apenas bem assessorado ele era uma pessoa que tinha experiencia e qualificação para fazer o trabalho que fez.

Sua expressividade na Igreja vinha do seu tempo como assessor e depois coordenador da JOC, período em que conheceu Cardijn e com ele trocou correspondência, de sua passagem em S. Luiz do Maranhão como bispo auxiliar, como religioso que participou ativamente do Concílio Vaticano II. Demonstra sua influência na Igreja a sua participação ativa na discussão com o governo para a implantação e expansão do Movimento de Educação de Base com financiamento do governo federal. Ele não apenas participou como sua opinião, contrária ao convênio, inicialmente foi seguida por bispos como Helder Câmara e Casaldáliga. Por essas coisas sua nomeação como bispo não foi confirmada para S. Luiz, aliás, o transferiram para Crateús com o intuito de mantê-lo afastado do centro do poder.

As Comunidades Eclesiais de Base iam surgindo a partir da convergência das vontades dos padres e dos populares. Sendo assim, fica claro que D. Fragoso, apesar da sua intenção de estabelecer em Crateús uma nova forma de ser Igreja, não impõe sua vontade sobre os demais. Procurou conversar, discutir, ouvir principalmente para sentir o que queriam os religiosos e os leigos. É claro que nesse processo de escuta vai colocando em discussão as diretrizes do Concílio Vaticano Il que, com tal, se impõem.

\footnotetext{
${ }^{51} \mathrm{Na}$ entrevista cedida a Alder Júlio Calado, D. Fragoso deixa claro que visitara 36 países, mantendo correspondências com figuras expressivas das igrejas desses países. Fragoso. 2007, p.68
} 
Nas diversas falas em que revela a sua inserção na Igreja de Crateús, D. Fragoso acaba por afirmar que o Vaticano II não é de imediato implantado pela Igreja mundial. Reconhece que a maioria dos bispos se entusiasma com o modelo que vai paulatinamente tomando forma durante o Concílio, mas ao retornarem aos seus lugares de origem, acabavam por se envolver nas questões locais, nos compromissos assumidos durante o tempo em que cada um dirigia uma Igreja particular e, com isso, as mudanças necessárias á construção de uma nova forma de ser Igreja, acabava por se perder.

Para ele, Medellin foi importante por provocar entre os bispos e padres do continente latino-americano o desejo de experimentar essa nova forma de ser Igreja. Não era estranho esse desejo na medida em que a maioria dos bispos vivia em regiões muito pobres, com problemas sociais complicados, marginalizados dos centros de decisão. As populações pobres não dispunham de mecanismos de pressão cerceadas que estavam pelos poderosos locais. Mudar essa realidade era a vontade de muitos, mas as mudanças dependiam de uma nova forma de ser Igreja, com maior presença leiga e com o aumento da presença de leigos e religiosos na vida das comunidades pobres.

A partir daí, retornando aos lugares de origem, vão buscar formas de organização que permita a inserção da Igreja na vida dos pobres fomentando o desejo de mudar, de transformar a realidade existente. Segundo alguns depoimentos, o de padre Elênio é um deles, não havia uma resposta, as comunidades eclesiais de base não surgiam como solução pronta e acabada. A forma comunitária aparece ao longo do trabalho de catequese, onde se procura aglutinar pessoas para discutir e celebrar a Palavra. É nesse processo que vão se conformando e se transformando as comunidades sociológicas em comunidades eclesiais.

Eu não sei se havia tanta essa preocupação de fazer uma igreja nova, mas procurava conhecer a realidade do povo e trabalhar um pouco essa realidade. Por exemplo, começaram 
as organizações do próprio povo sem se falar em comunidades, não se sabia nem o que era isso. A palavra mais usada naquela época era o sindicato, agora ao lado dos sindicatos as comunidades iam se organizando, tanto assim que os trabalhadores do campo, e todos eram trabalhadores do campo, começaram a se reunir mais, a perguntar, a querer saber das coisas. Aí, então a gente começou a dar uma feição à igreja, foi assim que começou. (Pe. Elânio em entrevista cedida ao autor)

Nessa mesma entrevista o Pe. Elânio, fala sobre a pedagogia usada pelos padres e religiosos no trabalho político-religioso que vão assumindo nas comunidades. No primeiro momento estimulam a leitura dos leigos membros da comunidade, depois, a partir da leitura, provocam o debate, os religiosos vão apenas orientando, coordenando o processo, sempre respeitando a fala dos leigos presentes.

O mesmo padre, se referindo à sua prática pastoral, afirma que não usa o espaço das missas para o debate sobre a realidade a partir da Palavra Revelada. Para ele, a missa é a missa, nela estão presentes pessoas com realidades e opiniões diferentes, portanto, quando quer debater a realidade das comunidades realizava reuniões nas próprias comunidades. Nesse caso, estavam todos irmanados numa mesma prática político-pedagógica, era a realidade deles que estava em foco.

D. Fragoso, em suas entrevistas a Alder Júlio e a João Fragoso, acaba por confirmar o que diz Pe. Elênio, não havia uma forma inicial para concretizar a nova maneira de ser Igreja. As comunidades aparecem como espaços naturais na medida em que existem no campo, elas são o resultado da expulsão do trabalhador rural. Ao sair das propriedades em que viviam como moradores ou parceiros, vão ficando nas franjas da propriedade já que não conhecem outra ocupação, esperando os momentos necessários do plantio e da colheita. Vivem dessa maneira problemas comuns: sem terra para cultivar se submetem as novas condições impostas pelos latifundiários.

Para o Bispo, essa realidade, esses aglomerados humanos, essas vilas, são espaços de vida, que sejam então espaços da Palavra. E neles a união 
decorria da realidade comum, da opressão que viviam, do êxodo que experimentaram, da pobreza sempre presente em suas vidas. Sua realidade presente era facilmente comparada com a realidade dos judeus e dos primeiros cristãos. O padre fazia essa ligação e o debate provocava a solidariedade entre os comunitários e o desejo de mudar. Dessa maneira, se transformam e indicam a forma de organização social e religiosa mais propícia a essa população.

Na medida em que as comunidades se fazem eclesiais surge a necessidade de pessoas qualificadas para assumir a coordenação dos trabalhos de base, pessoas qualificadas para motivar e manter o interesse de todos focado na sua realidade e no desejo de mudá-la.

[...] Uma vez que Medellin terminou, estava terminada uma proposta, um projeto. Um projeto só se torna prática popular transformadora (se) as pessoas o assumem, o entendem e o põe em prática. Para isso precisava haver vários encontros, em várias áreas da Diocese, ... . Houve vários encontros. Nós tivemos alguma assessoria especializada, como a de Padre José Oscar Beozzo, que nos ajudou muito a compreender o sentido de Medellin. Depois desse debate ou durante esse debate, nós íamos tentando colocar na realidade do povo aquilo que Medellin dizia, porque muita coisa que Medellin dizia já tinha começado com Paulo Freire, com a Educação de Base, com a Cáritas, na medida em que reunia as comunidades, para que as comunidades reunidas, estimuladas, pudessem dedicar-se a fazer sua própria sede, pudessem se reunir, reunir mais o povo e debater etc. Então todas essa coisas influíram para que Medellin encontrasse já um certo campo aberto para aplicação. E Medellin influiu muito no sentido de incentivar o povo em suas comunidades. Não se contentou em fazer pela Rádio Educadora de Crateús três programas semanais, para quem tivesse seu radiozinho, por todo canto, reunisse o seu pessoal e escutasse. Não se contentou apenas nessa comunicação. Foi muito mais longe porque ia discutir com o povo lá; ia ver como o povo estava fazendo, ia ver as ações que eles estavam realizando. E foi aí que a gente descobriu que, de fato, já havia aquilo que se chamava de Comunidade Eclesial de Base. (FRAGOSO. 2007, 45)

Dessa maneira, depreende-se das falas acima reproduzidas que não existia uma forma clara de como fazer a Igreja Povo de Deus. Ela vai aparecendo na medida em que se vai realizando ações que dê o protagonismo da 
história ao povo. Essa é a verdadeira Igreja dos pobres, dar voz a quem não tem, abrir espaços para a ação consciente e balizada, porque fruto do trabalho educativo, do diálogo entre companheiros de jornada. Por isso ela cresce, as comunidades se multiplicam, ninguém tem uma fórmula, todos contribuem para sua efetivação, esse é o grande mérito das CEBs e da Igreja de Crateús, por isso a adesão se torna tão grande e, aqueles que aderem, não temem a repressão, ou não se inibem diante dela.

Mas, D. Fragoso percebe que era necessário consolidar esse modelo, e o faz procurando formar pessoal para atual como motivadores dessa nova prática religiosa e política que constroem na Diocese. Não consegue perceber como religiosos formados numa outra forma de ser Igreja poderiam contribuir para a concretização da nova forma. Era necessário preparar agentes, coordenadores e padres para atuarem nas comunidades estimulando a ação pastoral e política dos seus membros, fazê-los protagonistas da história, da construção de uma nova sociabilidade, justa e igualitária.

Em Recife, D. Helder Câmara criou um seminário, o Serene II, e um instituto, o ITER, com o intuito de formar religiosos dentro dessa nova maneira de ser Igreja. Para essas instituições D. Fragoso encaminhou noviços para, mais tarde padres, retornarem a Crateús e atuarem junto com as Comunidades. Mas, a educação inicial desses jovens ficava por conta da Diocese, que os educava junto às comunidades, vivendo a realidade que os comunitários viviam gerando assim compromissos com essa história do povo de Crateús e redondezas.

[...] Crateús pensou assim: 'já que nós não temos confiança nos seminários clássicos - no Seminário de Fortaleza, no Seminário do Rio de Janeiro - nós vamos fazer que as comunidades eclesiais de base sejam a primeira etapa, até eles chegarem ao segundo grau, com uma experiência bem participativa. 
Com o afastamento de D. Helder Câmara, o Seminário e o Instituto foram fechados. D. Fragoso assume a formação dos seminaristas até o segundo grau pelo menos para que pudessem frequentar os seminários regulares sem sofrerem influência dos clérigos conservadores.

A visão de $D$. Fragoso era ampla e aberta, não determinava a maneira de ser Igreja, não impunha sua forma de ser Igreja, mas também não deixava em aberto. Sabia o que queria, mas não queria impor, portanto, negociava e assim se concretizava o modelo de Igreja que pretendiam e se construía coletivamente comprometendo todos aqueles que com ele conviviam. Comblin chama a atenção, nos idos de 1969, para a maneira democrática de ser de D. Fragoso, em nenhum momento ele impôs seu modelo de Igreja aos padres, deixando os conservadores à vontade para continuarem celebrando e atuando como sempre haviam feito.

Essa percepção de que não era toda a Igreja que se envolvia com as questões relativas ao novo modo de ser Igreja, envolvido a partir da Palavra com a realidade que envolvia a todos era também uma percepção dos leigos que participavam das CEBs ou de outros movimentos de Igreja. João de Paulo, assentado no Palmares I, afirma:

A gente era visto como ladrão, desonesto, só tinha coisa ruim em cima da gente daqui, a gente era sempre mal visto pela sociedade da cidade que não sabia o que era isso, não entendiam, e a gente sofria muito esse tipo de repressão.

Essa revelação de que a comunidade como um todo não apenas apoiava o movimento de ocupação de terra pelos sem terra como procurava coibir as ocupações acusando os ocupantes de ladrões de terra é confirmada por Flávio, também assentado, mas que só veio para o Palmares algum tempo depois por insistência da sua mãe. Ele próprio afirma ter condenado a ocupação de terra. Vejamos sua palavra:

A repressão que o acampamento sofria da comunidade, eu morava na comunidade do Curral do Meio e eu não deixava 
de dar um grito, porque isso acontecia porque eu não tinha o conhecimento, na verdade era toda aquela história que estava sendo construída.

É difícil para aqueles que foram educados, formados dentro de uma perspectiva, assimilando através da educação, da tradição, da Igreja e da força dos patrões de que a propriedade era sagrada, pois era fruto do trabalho de cada um; quem não tinha a terra ou não trabalhara o suficiente para tê-la ou seu trabalho não foi adequado à sua necessidade de possuir uma propriedade. A terra, como qualquer outra propriedade, era um prêmio que Deus dava àqueles que eram previdentes, isso já pregava Locke e, através da expansão do capitalismo, fora assimilado até mesmo pelos católicos. Dessa forma os capitalistas asseguravam e justificavam sua propriedade.

Olhando a entrevista cedida pelo Pe. Maurízio, pode-se ver a presença e a justificativa que os posseiros, especialmente os de Parambu, davam para não aceitar qualquer forma de ocupação da terra como sendo moralmente correta. Para eles que viam no latifundiário o invasor, a invasão não se justificava, pois retirava daquele que sempre viveu nela e dela o direito assegurado por seu trabalho e o trabalho da família. Somente se justificava a ocupação entre os moradores-parceiros, na medida em que, não tendo a propriedade legal do solo, tinha, no entanto, incorporado àquela terra o seu trabalho. Como dizia D. Moça, posseira no Cariri: "o trabalho fez a terra, sem meu trabalho e, antes de mim, o trabalho do meu pai, a terra não era terra." (ALBUQUERQUE. 1988, p. 156)

Essa visão que favorecia aos grandes proprietários da terra, passa naturalmente a ser questionada. Naturalmente, com isso quero dizer que é assumida como coisa natural, como decorrente de um direito natural proveniente, talvez, da vontade divina que distribuiu os talentos com as pessoas de forma desigual. Assim, premiou umas e castigou outras. Por quê? A vontade divina, o Plano de Deus não pode e não deve ser conhecido. 
Mas, a história das CEBs vem exatamente para questionar as verdades estabelecidas, criticar visões, inclusive da Igreja, endurecidas pelo tempo, esclerosadas pela evolução das sociedades humanas. Senão, vejamos o que garante a assentada Francisquinha ${ }^{52}$ :

\begin{abstract}
A ocupação se deu a partir do sindicato e das cebs. Porque era assim. Meu pai, ele sonhou a vida toda com a vida melhor para os trabalhadores rurais, assim no primeiro sindicato que tinha D. Fragoso, a Paulette, que foi criado em 1966, em Ipueiras, ele já se associou. E a partir daí começou o sonho da Reforma Agrária, porque também o sindicato foi criado com esse objetivo, da luta pela reforma agrária. Assim, a gente andou anos a dentro ocupando todos esses espaços, no caso das CEBs, do PT e no final nós percebemos que, ou nós ocupávamos uma terra na marra ou nós nunca teríamos uma terra limpa, para viver, para trabalhar, assim nós nos articulamos, mas não foi a única ocupação, nós ocupamos duas áreas prá poder chegar aqui.
\end{abstract}

Foi a partir das CEBs que o processo de organização, de debate sobre a realidade, em que a discussão sobre as visões de mundo, os conceitos estabelecidos e aceitos sem questionamentos, fossem criticados. Desse modo, passa a discussão sobre a terra, afinal como diz o próprio D. Fragoso, Crateús era área de latifúndios que oprimia e submetia de forma desumana os trabalhadores rurais. Rever, questionar a legalidade da posse, levantar outra possibilidade legal, um outro estatuto legal que reveja o direito absoluto à propriedade da terra, não é difícil para quem compreende a lei como fato humano, fruto das relações de força entre as classes ou segmentos sociais estabelecidos.

Mas, ocupar e ocupar sem mudança no estatuto legal, é mais difícil, envolve, como já foi discutido anteriormente, outros fundamentos, fundamentos que justificam e asseguram direitos, sem eles não haveria legalidade, não haveria segurança, não haveria, olhe aqui a visão moderna da propriedade, paz, respeito pelo outro. No entanto, essa visão, dentro dos espaços das CEBs, vai sendo questionada em função de um direito maior que é o direito

\footnotetext{
${ }^{52}$ Entrevista cedida ao autor em 18 de março de 2011.
} 
à vida. E é em função desse direito que pessoas, como os familiares de Francisquinha e a mãe de Flávio, assumem a ocupação e Flávio, no processo de discussão com seus familiares, absorve como justa a invasão da terra de Palmares.

As CEBs, em Crateús, mudaram as pessoas e o fizeram apenas por criar espaços onde elas pudessem falar, questionar, refletir sobre a vida que cada um, em seus lugares, vivia. É claro, a Palavra, ao ser lida, ao estimular o olhar sobre a realidade, um olhar diferente que vai além, que questiona, modifica as formas legais existentes, reformulam visões de mundo e fazem com que ações transformadoras ocorram.

\subsection{Os Sindicatos}

As Comunidades Eclesiais de Base são um primeiro momento de um processo de organização dos trabalhadores promovido pela Diocese de Crateús. Nele se encontram as pessoas, conversam sobre suas carências e veem na Palavra o estímulo para a luta e a organização. D. Fragoso, como muito dos seus auxiliares, viam no movimento sindical o momento mais importante, importante por levar as lutas dos trabalhadores por direitos aos demais trabalhadores, organizar as estruturas capazes de unir os trabalhadores, de organizá-los, de unificar as lutas, transformando todos em um só trabalhador coletivo capaz de lutar e compreender que sua luta, apesar das especificidades locais, são fruto de um mesmo processo de opressão e exploração que submete todos os trabalhadores.

Os sindicatos também se colocam como um canal legal, sua existência é normatizada, seus objetivos são definidos, sua relação com o Estado e com os segmentos dominantes é clara, apesar de ser limitada, as classes trabalhadoras organizadas em sindicatos não podem ultrapassar os limites legais, estreitos por sua origem, foram criados pelo Estado para 
contemporizar os interesses dos segmentos dominantes e dos trabalhadores.

Mesmo sabendo das limitações legais do sindicalismo no Brasil, D. Fragoso, acredita nas possibilidades que a organização sindical permite. No mínimo são espaços organizados, espaços que os trabalhadores podem usar para falar, dialogar, encontrar saídas para os problemas vividos pelos trabalhadores, ampliar, inclusive, suas lutas e seus direitos. O Estatuto da Terra é um avanço, a Lei que regulamenta as relações de produção no campo, se ainda estreita em seus limites, é um avanço grande quando aplicada no Nordeste Brasileiro. Os sindicatos através de sua estrutura nacional, CONTAG, ou através de sua estrutura regional, a FETRAECE, criam laços de solidariedade entre os trabalhadores, permitem que se percebam como uma classe, com interesses comuns e opostos aos interesses dos segmentos dominantes.

Essa compreensão se revela quando D. Fragoso escolhe para trabalhar a organização dos trabalhadores rurais da Diocese, a trabalhadora francesa Paulette Ripert pertencente ao Sindicato dos Trabalhadores Cristãos da França. Para João Fragoso:

A Diocese não procurou especialistas (sábios e inteligentes) para acompanhar e ajudar o pessoal do campo na sua conscientização e na sua organização. Valeu-se de uma modesta operária francesa integrante do Sindicato dos GT Trabalhadores Cristão da França para essa tarefa. (JOÃO FRAGOSO. 2005, p 345)

Chama à atenção a afirmativa de que D. Fragoso não chamou especialistas, pois, a Igreja Católica no Brasil tinha vários. Afinal, a Igreja no Brasil começa a fundar sindicatos, principalmente de trabalhadores rurais, a partir do final dos anos de 1950 e início dos anos de 1960. Basta lembrar a ação de D. Eugênio Sales, no Rio Grande do Norte, dos padres Crespo e Melo em Pernambuco e a fundação dos sindicatos do Cariri Cearense a partir de 
1962. Foram criados, nesse ano de 1962, cinco sindicatos pela Fundação Padre Ibiapina da Diocese do Crato.

Por que, então, não procurar os padres e os técnicos ligados as dioceses católicas para a organização dos sindicatos da Diocese de Crateús? Talvez pesasse contra as dioceses brasileiras o fato de terem criado os sindicatos com um objetivo central de combater as outras correntes políticas interessadas na organização dos trabalhadores rurais, do seu anticomunismo, às vezes irracional e das posições conservadoras quanto a Reforma Agrária e a colaboração entre as classes sociais. A literatura a respeito é farta e já foi amplamente citada neste trabalho.

$\mathrm{Na}$ realidade, ao convidar uma sindicalista católica francesa, quisesse afirmar o cristianismo católico como uma corrente religiosa que defendia antes de tudo os interesses dos trabalhadores, e o defendia a luz do Evangelho que indica os pobres como objeto do amor cristão, afinal foi na França que os padres se envolveram de maneira radical na organização e luta dos trabalhadores, não esquecer os padres operários da primeira metade do século XX. Chamar uma católica francesa deixava clara a posição de radicalidade da Diocese e de seu bispo. A própria ação da Paulette, vivendo como os pobres e renunciando a qualquer tipo de ajuda financeira externa, é uma confirmação dos motivos da escolha de D. Fragoso. João Fragoso faz uma longa citação de texto da Paulette que me vejo obrigado a reproduzir, pois ele diz bem quem é essa sindicalista francesa e porque seu jeito de fazer o sindicato, nesse primeiro momento, deu certo:

Saí da França para o Nordeste do Brasil, em novembro de 1964, para tentar ajudar a organização de sindicatos de trabalhadores rurais.

Este objetivo apresentava logo pontos positivos e negativos.

Eu não conhecia nada do Brasil nem do seu povo. Só sabia um pouquinho do que se falava na França: 'Países subdesenvolvidos, fome, seca'. Não conhecia a língua, mas só um pouco do português de Portugal.

Eu acreditava com força: 
1. No tipo de sindicalismo que eu conhecia e nas suas possibilidades para incitar os trabakhadores a resolverem por si mesmos seus problemas.

2. Nas possibilidades de cada pessoa para encontrar o meio de resolver seus problemas sem paternalismo.

3. Outro ponto que se revelou positivo (eu acho) é que eu era uma mulher (no ponto de vista de muitos), incapaz de levar a cabo tal trabalho, mas era somente capaz de dar assistência social, médica e caritativa.

Tinha sido previsto que eu seria membro de uma equipe dirigida por brasileiro.

No final encontrei-me sozinha, e isto foi positivo pois contribuiu para os camponeses assumirem mais e mais rápido responsabilidades.

Sabendo que o sindicalismo brasileiro era do tipo vertical, submetido ao Ministério do Trabalho sob um governo ditatorial, a pergunta que me deu muitas dores de cabeça foi esta:

Ajudar o povo a entrar nesse tal sindicato - ou fazer logo uma oposição sindical clandestina?

Eu conhecia um pouco das 'Comissiones Obreras ' da Espanha sob a ditadura.

Decidi utilizar o que existia ou seja, em governo ditatorial, utilizar as leis existentes para organizar sindicatos, mas com espírito diferente.

Eu sabia que era um trabalho difícil e também demorado. $\mathrm{Na}$ França passava-se de um a dois anos para conseguir algo numa empresa, às vezes mais. Por isso não tinha certeza de conseguir algo, mas sabia que de qualquer forma ia plantar uma semente que qualquer dia daria frutos.

Devia primeiro conquistar a confiança do povo, conhecendo-o e (a) sua vida, seus problemas etc., e também devia fazer com que me conhecesse. (Paulette, in J. Fragoso. 2005, p. 146)

Depreende daí que, ao pretender uma base atuante a partir de entidades, comunidades ou sindicatos, democráticas, D. Fragoso, no entanto, não renunciou ao seu papel de líder, líder religioso nomeado, mas mesmo assim líder, a demarcar a ação, a definir caminhos e procurar trazer o povo para dentro dele. Se o povo o iria ampliar, rejeitar, mudar sua direção era a incógnita que queria arriscar. Decidida sua ação, iniciada a ação, caberia a ele, por crer na eficácia da mesma, convencer os demais que, sabendo o caminho a percorrer, poderiam rejeitá-lo ou assumi-lo. 
Paulette vai assumindo o mesmo risco; fundar um sindicato, fundar mais de um sindicato. Sabia das restrições legais, mas tinha a compreensão de que um sindicato é um espaço de aproximação das pessoas, que o sindicato tinha a possibilidade de gerar um sujeito coletivo, de fazer de cada um sujeito de compreensão da realidade ao mesmo tempo de capacitá-los a ação. Sabia que a própria ditadura teria, por sua vez, limites à sua intervenção repressora, a lei estabelecia esses limites, mas também o sujeito coletivo, a entidade social, a instituição que era o sindicato, impunha limitações à ação do Estado e das forças repressoras de então.

Assim, o sindicato é um instrumento de luta que é usado pelos trabalhadores rurais de então que, ao mesmo tempo, limita a atuação das lideranças sindicais, amplia os direitos dos trabalhadores e impõe limites a ação coercitiva dos proprietários de terra. A vontade dos latifundiários passava a encontrar barreiras legais amplamente utilizadas pelos sindicatos em favor dos trabalhadores. A própria Paulette reconhece essa existência contraditória e antagônica dos sindicatos, limita, mas amplia direitos inclusive o direito a ser uma pessoa dotada de direito.

No seu trabalho, reproduzido por João Fragoso, a ativista sindical Paulette descreve uma situação que deixa clara as mudanças que ocorreram na Diocese de Crateús, que eu transcrevo aqui:

Cheguei um dia em casa e logo depois apareceu o presidente do Sindicato. Contou-me que um sócio havia sido ameaçado de despejo pelo dono da terra onde trabalhava. O presidente me explicou que não era conforme a lei e que tinha convidado o dono da terra ao sindicato para resolver o problema.

Fiquei apavorada! Pensei que tudo ia se acabar, que o dono da terra não iria, mandaria a polícia etc. Mas não se podia voltar atrás. Aí expliquei ao presidente: 1) que não devia estar sozinho, 2) que devia preparar os argumentos. Pedi para ele vir me contar o resultado.

Pois foi assim. O dono da terra foi ao sindicato. O presidente mostrou para ele o livro das leis onde estavam escritos os direitos do trabalhador.

- Não podia despejar antes da safra.

- O trabalhador só devia ao dono uma parte da safra determinada pela lei.

O dono da terra também estava em falta porque não fez um contrato com o trabalhador. 
No final foi uma vitória total. O trabalhador não somente não foi despejado, mas teve um contrato conforme à lei. (PAULETTE. Cit. João Fragoso." 2005, 356)

Gostaria de frisar alguns pontos do depoimento de Paulette. O primeiro deles, é que ela ficou receosa, não acreditava que o proprietário da terra pudesse atender ao chamado do presidente do sindicato, depois que ele atendesse à lei, sem discutir, mas a acatasse, e por fim que ele permanecesse com o parceiro em sua terra.

Lembrando algumas práticas no Cariri Cearense, ocorreram com sindicalistas, membros de diretoria de sindicatos, verifico, são depoimentos ${ }^{53}$ que afirmam que todo ou qualquer sindicalista ou trabalhador rural que criava problemas para os proprietários de terra, que questionavam com base na lei e promovia ação através do sindicato, tinha seu nome divulgado entre os proprietários para que estes não cedessem terras, não estabelecessem contratos de parceria com os mesmos.

Situação complicada na medida em que sem terra não havia produção, sem produção era a fome, o desespero. No entanto, no caso específico relatado pela ativista acima citada, não só o proprietário vai ao sindicato, portanto, reconhece a autoridade do sindicato, como acata a lei, não mais expulsa o trabalhador e, estabelece com ele, conforme a lei, um contrato em que cede a terra para que o último produza.

Muda tudo, a postura do proprietário muda como muda a postura do trabalhador. A partir daí o sindicato, que a ativista temia que desaparecesse a partir dessa questão, se fortalece. Mais trabalhadores se associam mostrando que a posição assumida por D. Fragoso de construir sindicatos estava correta. Os sindicatos, mesmo que vigiados e sujeitos a repressão, eram instrumentos legais, de uma legalidade que não havia sido extinta e ${ }^{53}$ O que estou relatando aconteceu com o sindicalista de Assaré, Nozinho. Ele hoje está no
Assentamento 10 de abril, em Crato. 
que, como afirma Comblin ${ }^{54}$, era necessária para legitimar a ditadura militar entre os diversos segmentos sociais, principalmente as classes médias brasileiras.

D. Fragoso compreendia isso e tanto o compreendia que na medida em que os sindicatos saiam da esfera da lgreja e pelegavam, ele procurava retomálos. É preciso, no entanto, deixar claro que a influência da lgreja sobre o sindicato não era desejada nem por D. Fragoso e nem por Paulette, mas era um dado, afinal a Igreja era uma instituição forte e sedimentada nas camadas populares como o espaço do divino e do sagrado, espaço de conforto, portanto, espaço onde encontravam proteção para atuarem segundo as novas regras.

Em depoimento gravado por este autor, Maria de Jesus, ex-sindicalista em Crateús e Ipueiras, dirá:

Em 1972, com a campanha da fraternidade que era educação para todos eu fui chamada por padre Irismar, (para trabalhar) com alfabetização de adultos, ligado (a) na vida. Eu fazia parte da coordenação das CEBs. Nessa coordenação tinha que envolver (também) a luta sindical e pra isso nós criamos uma oposição sindical em 1972 ou 1974, lutava contra o sindicato pelego e a favor do sindicato atuante, sindicato pela base, era a oposição sindical, nós fizemos uma comissão, nós recebíamos nosso treinamento, a gente tinha nossas reuniões, nossos encontros, manifestações, visitas nas comunidades tudo aí apoiado por D. Fragoso.

Chama a atenção o fato relatado na entrevista. Os sindicatos na região da Diocese de Crateús foram criados pela Diocese através de Paulette. Em seu depoimento ela se referia à necessidade de se manter as lideranças livres de qualquer ingerência que não fosse da base dos próprios sindicalistas. Mas, ao ouvirmos os depoimentos de várias lideranças das bases, inclusive

\footnotetext{
${ }^{54}$ Para Comblin : “dentro do sistema atual, há ambiguidades que permitem limitados modos de agir no campo social. O sistema precisa manter e desenvolver certas estruturas sociais, tais como os sindicatos, e, ao mesmo tempo, procura conter e limitar a atuação das estruturas sociais de que precisa. Daí a batalha pelo controle das organizações sociais. Precisamos aproveitar a abertura que o sistema não pode negar. Pois os camponeses não vão aceitar aventuras fora da legalidade. Por outro lado, precisamos lutar contra o controle das organizações pelas forças do sistema. Os sindicatos rurais constituem estruturas ambíguas. Ora, no plano social quase toda a atuação possível se faz por intermédio de tais organizações. Esta não estão totalmente predeterminadas. Deixam possibilidades de interferências. (COMBLIN. 1971, p. 9)
} 
e principalmente Luis Antonio e Maria de Jesus, verifica-se, já em 1972, a necessidade de se contrapor, se constituir uma oposição sindical. Maria de Jesus é chamada para preparar lideranças para o embate, ela própria irá se constituir em liderança, que irá compor, com outras pessoas, um conjunto de sindicalistas chamados de autônomos.

Como explicar essa situação? Como pessoas que foram preparadas numa linha sindical voltada para as bases, representativa das bases acaba por aderir a estrutura sindical, a compactuar com os latifundiários, submeter-se ao assistencialismo provocado pelo FUNRURAL e outros programas do governo que acabavam por sobrecarregar os dirigentes evitando que os mesmos estivessem presentes no dia-a-dia dos trabalhadores?

Essa questão não é difícil de responder. Existem várias análises que explicam a ausência dos dirigentes nas bases, ouvindo-as, representando de fato seus interesses, vendo-se como trabalhador igual aos por eles representados. Essa situação não existia apenas em Crateús, eu me defrontei com ela no Cariri quando estudei a origem e o desenvolvimento dos sindicatos daquela região. Expliquei através de Michells. Para esse autor, os dirigentes sindicais passam por um processo de mudança nas suas vidas que os distanciam da base. São retirados do espaço de trabalho para ocuparem a administração dos seus sindicatos, mudam suas relações pessoais, passam a contatar com assessores, com lideranças sindicais e patronais, dentro de espaços que não eram os seus, ganhando salários mais significativos para fazer frente as despesas que passou a ter com a mudança, no caso deles, do campo para a cidade. Seus filhos passaram a frequentar escola, conviver com crianças de outras camadas sociais, com expectativas de vida diversas daquelas que teriam se permanecessem no campo. Muda tudo, dificilmente o dirigente sindical vai querer voltar a situação de antes.

Antonio Luis irá dizer, de maneira mais clara e direta, que: 
No começo ninguém andava nem de bicicleta, era a pé, aí como era que o cara ia se corromper, não tinha jeito. Depois, eu já era dirigente, os transportes vieram aparecer depois, aqui em Novo Oriente tinha uma rural, que foi dada não sei por quem, já de 1975 prá cá. Mas, nós estamos falando do começo, no começo, estou falando das dificuldades que nós encontramos, eu também fui um dos primeiros associados do sindicato de Ipueiras. Quando eu entrei ele estava com um ano. Só tinha um birô, tudo estava na gaveta. O presidente morava na Matriz de S. Gonçalo, pegava o sindicato botava dentro de uma bolsa e... . O sindicato funcionava num casa emprestada, aí a gente ia pra briga mesmo porque era necessário. Quando o FUNRURAL entrou ai a coisa mudou, quem gostava de dinheiro fez como João Alencar, fez como aquele velho da Independência, o de Tauá.

Mais adiante, fazendo alusão à origem e à formação dos dirigentes, querendo dizer que independente da proximidade da Igreja, das CEBs ou não, muitos dos dirigentes acabaram por se corromper e manter-se distantes das questões dos trabalhadores, transformando-se em pelegos:

Na época todos os dirigentes sindicatos foram, eu costumo
dizer, foram crias de D. Fragoso. O George foi da CEB, que
foi do primeiro sindicato da Região que foi de lpueiras, depois
teve o da Poranga, o daqui também João Alencar também era
da ceb e respondendo a sua pergunta houve um período que
cada um tinha seu jeito, teve um que se corrompeu e um se
corrompendo põem a perder o resto. George que era do
sindicato de Ipueiras era muito mal visto pelos padres da
Diocese de Crateús e passou por um processo que do jeito
que a Diocese queria nós queríamos também.

Diante da corrupção, da adesão dos dirigentes sindicais aos interesses patronais, foi necessária, novamente, a intervenção da Diocese. Mas esse foi um movimento mais articulado que aconteceu em todo Estado e em todos os sindicatos. Houve uma reviravolta, a militância sindical se acentua, a base diante da inoperância dos sindicatos, envolve-se na luta e, finalmente, os sindicatos retomam uma linha mais afeita aos interesses dos trabalhadores.

Esse apoio dos sindicalistas às oposições sindicais está vinculado às lutas necessárias, principalmente na chamada região da Serra, a regularização das posses e a defesa dos posseiros pressionados pelos latifundiários. Entre os moradores-parceiros, a briga era pela validação, pela efetivação dos 
direitos assegurados no Estatuto da Terra e no Estatuto do Trabalhador Rural. Os trabalhadores requeriam segurança, queriam garantias de que não teriam suas terras invadidas pelo gado, que pagariam uma renda justa, como estava estabelecida na lei.

A modernização do campo necessária para atender às demandas da indústria e das populações urbanas, encontrou, na ausência de uma legislação clara e do compromisso daqueles que são responsáveis pela efetivação do direito, juízes, promotores e advogados, campo fértil para disputas que acabaram por favorecer o latifúndio e os empresários agrícolas, seus sócios. Mas, esse processo de avanço dos segmentos dominantes sobre as terras, desconhecendo os direitos dos trabalhadores, não aconteceu sem reação. Em muitos lugares, nos diversos municípios pertencentes à Diocese de Crateús, ocorreram ocupações de áreas possibilitando os assentamentos e a intensificação da luta pela Reforma Agrária.

\begin{abstract}
A ocupação se deu a partir do sindicato e das cebs. Porque era assim, meu pai ele sonhou a vida toda com a vida melhor para os trabalhadores rurais, assim no primeiro sindicato que tinha D. Fragoso, a Paulette que foi criado em 1966 em Ipueiras ele já se associou. E a partir daí começou o sonho da Reforma Agrária, porque também o sindicato foi criado com esse objetivo, da luta pela reforma agrária. Assim a gente andou anos a dentro ocupando todos esses espaços, no caso das CEBs do PT e no final nós percebemos ou que nós ocupávamos uma terra na marra ou nós nunca teríamos uma terra limpa, para viver, para trabalhar assim nós nos articulamos, mas não foi a única ocupação nos ocupamos duas áreas pra poder chegar aqui.
\end{abstract}

Em Crateús os sindicatos foram criados com esse intuito, lutar pelos direitos, pela efetivação dos direitos. Como referenciou o Padre Maurízio, a região de Crateús era uma área de conflitos rurais de longa dada, os primeiros conflitos se originaram em função das tentativas de expulsão dos posseiros da Serra da Ibiapaba, depois, com a modernização e a legislação trabalhista, proteção para os agricultores, mas uma ameaça para os latifundiários que 
financiavam ou cediam as terras para que os moradores e parceiros produzissem o algodão.

Diante da situação do homem do campo, aparecia o sindicato como uma solução na medida em que respaldado na lei, no movimento sindical nacional, na força daqueles que compunham sua base. D. Fragoso sabe disso e por isso promove cursos sobre sindicalização, identifica e respalda as lideranças que surgem. Sabe que além da força do movimento sindical, é necessária a força da Igreja Institucional, por isso sua presença, a presença de pessoas ligadas a ele na mobilização pela criação dos sindicatos de trabalhadores rurais e nas lutas que são desenvolvidas a partir daí, principalmente nas épocas secas para atendimento de todos os trabalhadores prejudicados.

Renda, morava em terra dos outros pagando renda. Diante da situação em que vivia meu pai acabou por entrar na discussão da criação do sindicato, a Paulette falou do assunto e ele achou que era o caminho, aí ele começou e foi levando os filhos e outros companheiros ... Ai tinha a Igreja, D. Fragoso, e tinha muitos cursos e a gente se engajou lá fazendo muitos cursos profissionalizantes e, às vezes até de alfabetização. Depois veio as cebs, que nas cebs foi um momento assim altamente importante na vida dos camponeses. As músicas que cantavam sobre a origem das terras, musicas que encorajavam o pessoal a não ficar calado, então foi assim que a gente se envolveu nas cebs, evangelizar. Trazer a luz do evangelho para a luta era altamente importante aquele momento na história, porque foi um momento muito educativo, mas também um momento de muita repressão. mas a gente resistia. Nessa época a gente morava no município de Ipueiras que foi o primeiro sindicato criado, depois a gente se mudou para Crateús e começou a contribuir com o sindicato aí foi a vez de criar o partido político, nós sempre estivemos envolvidos no movimento por conta que a gente acredita que sozinho ninguém é capaz tem que está junto com seus iguais.

Para Francisquinha, que nos deu esta entrevista, apesar de todo o esforço, esforço que foi de muitos, padres, camponeses, cebianos e do Bispo, mesmo assim o sindicato passou por dificuldades, seus dirigentes acabaram por diminuir o ritmo das lutas, dos enfrentamentos, acomodando-se às condições impostas pelos segmentos dominantes e seus associados, os 
militares. Não se pode esquecer que em Crateús havia um Batalhão de Engenharia, administrado por um coronel do Exército Brasileiro a quem cabia decidir sobre quem reprimir, coibindo, inclusive, as mobilizações dos trabalhadores.

A percepção de Francisquinha, no entanto, vai mais longe:

O problema é que os iguais não quer se juntar com a gente ${ }^{55}$, acabam jogando a nossa história no esgoto. As organizações que nos davam apoio hoje estão muito moderadas, as cebs hoje existem ainda, mas estão muito moderadas, o MST está muito moderado, começa moderando e a gente pensa que está resolvendo o problema e ai continua, resolve para meia dúzia de pessoas e outras pessoas não conseguem resolver. Hoje aqui dentro do assentamento eu acredito que tem, uns dois ou quatro que estão muito bem mas nós temos companheiros que nós não conseguimos trazer mais nós, a gente não conseguiu trazer para melhorar também.

Mas, mesmo assim, percebemos que a história da população de Crateús mudou e mudou muito. Os trabalhadores lutaram e continuam lutando pela terra. Conquistaram, ao longo desses anos, mais de vinte assentamentos em Crateús. Se compararmos com o número de assentamentos em todo o Estado percebemos, que na região da Diocese de Crateús, o número de assentamentos e de assentados é muito grande.

Mas não é apenas a existência dos assentamentos intermediados pelo INCRA que indica moderação, esta inclusive deve ser apreciada com cuidado. Como também a visão dos camponeses, que foi mudando ao longo dos anos, se antes, segundo entrevista do Padre Muarízio, eles condenavam as ocupações, hoje eles a aceitam.

\subsection{O Jeito CEB de Ser}

\footnotetext{
${ }^{55}$ A entrevistada faz referência ao trabalhador que não se aproxima do trabalhador, mas daquele que é poderoso. Existe um ditado, muito difundido entre os pobres, que a gente deve ficar embaixo de pau que dê sombra.
} 
Fica claro, hoje, mesmo quando se fala de crise das CEBs, relativizar essa crise. Para o vigário de Tauá, padre Maurízio, a liberdade hoje de organização permite que as pessoas procurem o melhor canal para suas demandas. Afinal, existem associações de bairro, sindicatos para os trabalhadores das mais diversas categorias, partidos políticos, organizações não-governamentais de diversos tipos. Todas elas atuando na sociedade política, reivindicando, cobrando e criticando a ação dos governos e dos segmentos dominantes em sua relação com os trabalhadores.

Talvez por isso, a importância das Comunidades Eclesiais de Base não apareça como apareciam nos anos de 1970 e de 1980. Mas, foram nelas, que os segmentos populares, principalmente na Diocese de Crateús, assumiram a cultura da cidadania, assumiram a política na sua forma ampla, o exercício da fala, da crítica e da cobrança. Foi através das comunidades eclesiais de base que viram a importância da organização, da união e da articulação dos movimentos, mesmo quando os objetivos pleiteados parecem distantes, diferentes. Articulação que se percebe necessária no plano local, regional e nacional. As lutas são expressão de cidadania, todas elas são necessárias e educativas, pois promovem o aprendizado, ampliam a percepção, direcionam a ação.

Essa percepção das CEBs como locais de aprendizado político, aparece em Doimo (1995), mas aparece também na entrevista cedida por Machado ${ }^{56}$. Para a primeira as Comunidades foram os espaços de onde emergiram e se espalharam os chamados novos movimentos sociais. Eram elas que davam sustentação financeira, política e social aos movimentos e permaneciam após o desparecimento dos mesmos, fazendo a ligação entre os grandes eventos nacionais e transformando-os em espaços e instantes educacionais. Doimo, analisa a efemeridade dos movimentos sociais, afirmando que eram instantes políticos que logo, atendido seu pleito, evanesciam, por isso ela os enquadra nos movimentos de ação direta.

\footnotetext{
${ }^{56}$ Machado é vigário do município de Ipueiras e um dos coordenadores técnicos da Escola Família Agrícola D. Fragoso desta cidade.
} 
Mas as Comunidades permaneciam, atentas e mobilizadoras, políticas, a discutir a vida, os problemas, os direitos. Eram escolas de fazer política. Para Machado, as CEBs, se diminuíram a intensidade de seu movimento, se baixou o número de participantes e a quantidade das comunidades na Região de Crateús, no entanto, entranhou em todos a forma de ser CEBs, é o que ele chama de jeito de ser CEBs.

As pessoas aprenderam com as CEBs que têm direitos, que os direitos devem ser reconhecidos e efetivados, que a política é a única maneira de mudar o jogo, que os políticos, pelo papel que exercem, devem ser vigiados e revelar seus compromissos. Aprenderam também que somente organizados podem fazer valer sua voz e por isso geraram novas organizações, mais específicas e mais articuladas. Para Machado, em entrevista cedida a este autor:

Eu vejo o seguinte que as cebs também mudaram de feição, hoje se fala muito mais do estilo cebs do que mesmo das cebs. Mesmo que em muitas paróquias digam que não tem cebs mas o pessoal continua no seu jeito de enfrentar a vida, de fazer a celebração, de conduzir as coisas é um pouco dentro dessa lógica das cebs, do estilo cebs, de fazer consultas, de valorizar as expressões populares, de trabalhar junto, de muitas iniciativas. Eu acho que esta coisa está muito presente, mesmo em paróquias que o pessoal diga que não tem mais cebs.

Mais adiante dirá ainda:

Essas coisas são muito entranhadas hoje, de modo que o pessoal, muita gente assumiu essa questão política, outras não, ficaram mais no campo eclesial, mas procurando fazer esse entrosamento, essa ligação. Não pode misturar, você não encontra em canto nenhum o pessoal com essa linguagem, não pode misturar religião, Igreja, política, o pessoal não faz mais essa dicotomia. Eu acho que isso foi um ganho muito importante.

Assim, a compreensão dos religiosos, no caso específico acima de Machado, é aquela que afirma o aparecimento de várias formas de 
organização e manifestação, tanto dentro da Igreja como, também, fora dela nos espaços que a sociedade foi criando para dá vazão as suas inquietações e conformar a sociedade aos seus interesses.

Essa visão compartilhada por Pe. Maurízio, indica que a sociedade é plural, nela emergem constantemente correntes diversas de pensamento e interpretação do social que decorrem da maneira como cada segmento de classe, cada segmento político, entra em relação com os demais, relações que podem ser conflitantes em função de interesses opostos, convergentes quando os interesses podem ser ajuntados fortalecendo os segmentos interessados neles, conflitantes, antagônicos etc. Afinal a sociedade é cada vez mais um conjunto amplo de agrupamentos, de sujeitos coletivos, representando interesses econômicos, políticos, sociais e culturais diversos, que entram em contato uns com os outros prevalecendo aqueles que pelas circunstâncias objetivas representam grupos mais fortes e convincentes.

A citação a seguir de trecho da entrevista com o padre Maurízio, parece indicar sua compreensão dessa complexidade que não anula as comunidades de base, que a fazem parte, mas não a mais completa, apenas aquela que estimula o debate, a discussão e a organização dos segmentos populares que nesse quadro complexo tenta fazer prevalecer seus direitos, sua vontade, sua visão de mundo.

Qual é o jeito de interpretar teologicamente e sociologicamente essa pluralidade, nem sempre, nem os padres, os agentes de pastoral, que acompanham nas comunidades, tiveram a capacidade de fazer e nem a instrumentação teórica dos militantes da comunidade tiveram então de entender o fato de que estou militando na associação, de que estou fazendo reivindicação isso tem a ver com minha fé e o principio dessa minha ação na associação ou no sindicato, que são momentos separados, mas tem uma unicidade dentro da minha compreensão e de visão do mundo, a coisa é bem mais complicada se pensada, realizada, descrita e analisada de que quando o único espaço eu vou cumprindo todas as tarefas da minha vida. 
Para o padre em questão, as CEBs deixaram de ser o espaço para se transformar em um dos espaços fundamentais ao processo de desenvolvimento humano. Para ele, estes espaços são tão importantes como as CEBs e como elas são espaços de manifestação da minha religiosidade, afinal esta se manifesta na vida e esses espaços são espaços de vida, espaços vitais. Nesses espaços, se posso ir mais adiante em minha interpretação das falas dos padres, se manifestam as CEBs, o jeito de ser CEB, igreja viva que atua na sociedade, que a reelabora para comportar todos os homens e toda a diversidade humana, claro que não é qualquer uma, mas somente aquelas que promovam o homem no sentido de ser mais humano, como o dizia e desejava Paulo Freire. 


\section{CONCLUSÃO}

As Comunidades Eclesiais de Base ainda existem em atividade em Crateús. Continuam reunindo, continuam nas comunidades rurais estimulando a organização e a luta do povo contra os percalços que se colocam em seu caminho. Estive em duas reuniões da coordenação da CEBs. Nas duas reuniões, as questões levantadas ainda focam as condições de vida, de trabalho e a inserção política dos segmentos populares na sociedade cobrando, do poder público, ações condizentes com as aspirações dos trabalhadores.

Não podia ser diferente, as primeiras comunidades remontam aos anos de 1960 com a chegada de D. Fragoso. Sua visão de Igreja vai modificando e conformando a visão que os padres e leigos da região de Crateús tinham. As condições de vida em que viviam os trabalhadores, principalmente os trabalhadores rurais que eram, na época, a grande maioria da população, acabam por contribuir para que as mudanças ocorram.

Em entrevista reproduzida nesse trabalho, o Pe. Maurízio lembra que um segmento bastante amplo dos trabalhadores do campo era constituído por posseiros, ou seja, pessoas que moram e trabalham na terra sem o título de propriedade. A Lei assegura que, se durante mais de dez anos, não tiveram a terra reclamada, a posse é efetivada. Mas, por volta dos anos de 1980, as terras da Serra da Ibiapaba, nos arredores do município de Parambu, passaram a ser reclamadas por latifundiários forçando os trabalhadores a se defenderem.

A Diocese fornecia os elementos para defesa dos trabalhadores. Conhecedores da legislação relativa ao campo, padres, assessores e sindicalistas, sabiam que existiam garantias legais que asseguravam a posse da terra. Esse conhecimento fora trazido para a região, que antes de D. Fragoso não dispunha de sindicatos rurais, pela ativista sindical francesa 
Paulette, chamada a Crateús por D. Fragosos para promover a fundação dos sindicatos rurais.

Mas, a organização dos sindicatos não estava voltada apenas para essa questão. Como vimos no trabalho de Beserra (1990), a situação do homem do campo era complexa por volta dos anos de 1960 e 1970, momento de criação e expansão das Comunidades Eclesiais de Base. Não eram apenas os posseiros que reclamavam a propriedade da terra como direito seu. Também havia os trabalhadores caracterizados como moradores -parceiros que estavam sendo expulsos. Na maioria, era cultivadores de algodão, cultura chamada de raiz que assegurava direitos ao trabalhador. $O$ algodão é uma planta que produz durante mais de dez anos, se o proprietário requeria a terra, tinha que indenizar o trabalhador pela produção futura.

A Lei passava a garantir direitos, o domínio sobre a terra começava a ser restringido. O proprietário já não podia estabelecer sua vontade como único limite. Essa modificação nas relações de produção acaba por transformar o processo produtivo, os proprietários passam a usar máquinas agrícolas, a criar animais e plantar culturas que não requerem tanta força de trabalho.

Mas os trabalhadores não aceitam as mudanças pacificamente. As condições de existência dos trabalhadores modificaram-se ao longo dos anos sessenta do século passado. A chegada de D. Fragoso, sua visão de mundo e de Igreja, acaba por impactar nas relações entre as elites, que dispunham da força, com os trabalhadores, acostumados a não ter direitos. Sabia-se que os trabalhadores de Pernambuco e de outros recantos lutavam pela Reforma Agrária, por uma legislação trabalhista para o campo, por garantias legais que assegurassem a sobrevivência dos trabalhadores.

Mas o que acontecia, acontecia longe. Toda a pesquisa que realizei em livros e documentos, relacionados na bibliografia, as entrevistas que fiz, as pessoas com quem conversei, foram unânimes em afirmar as mudanças que aconteceram em Crateús após a chegada de D. Fragoso. Pode-se dizer que 
as condições objetivas, o processo de modernização que expulsava o homem do campo, forçavam os trabalhadores a reagir. Sem a terra, ele compreendia, não conseguiria viver ou sobreviver com sua família.

Mas disso sempre soube. Sempre que por um motivo ou outro era expulso por vontade do patrão, sabia que ficaria sozinho, não tinha a quem recorrer, não tinha proteção. Sua sina era submeter-se a outro, proprietário de terra, cada vez, ainda mais submisso, mais calado, olhar no chão como queria o personagem de Graciliano Ramos em Vidas Secas. Com a chegada de D. Fragoso, as coisas mudam.

A situação mudou porque passou a contar com a lgreja, mesmo que não contem com toda a Igreja, contam com o bispo, naquela Diocese a figura mais importante, pois situada no ponto mais alto da hierarquia. Mesmo contrariados, os opositores de D. Fragoso, não podiam fazer muito contra sua pregação. Afinal, parte da população de Crateús sabia das mudanças que estavam ocorrendo na Igreja Católica a partir do Concílio Vaticano II.

A Igreja é um poder, isso é reconhecido pelos fiéis e pelas elites políticas e militares. Esse poder estava do lado dos trabalhadores, isso mudava as coisas, mudava o equilíbrio de poder então existente, mesmo que depois combatam e muitos padres acabem presos, perseguidos e expulsos, o poder, da Igreja e do bispo, permanece, senão intacto, pelo menos, inabalável. D. Fragoso continua bispo da Diocese, continua por anos fazendo a sua ação pastoral voltada para os mais pobres, não modifica seu discurso, não restringe sua ação.

As condições de vida dos trabalhadores muda, são expulsos do interior da fazenda, passam a viver fora das propriedades rurais, mas perto o suficiente para trabalharem nos tratos iniciais e nas colheitas, chamados pelos proprietários. Essa saída do latifúndio e a necessidade de trabalho, faz com que os trabalhadores passem a construir moradias precárias nos arredores 
do latifúndio, constituindo comunidades, chamadas por D. Fragoso e Frei Beto, de comunidades sociológicas.

A existência dessas comunidades facilitou o trabalho da Igreja. D. Fragoso utiliza, para começar seu trabalho pastoral, dentro de uma nova perspectiva de Igreja, aqueles e aquelas que já vinham de muito tempo fazendo um trabalho de educação religiosa: os catequistas. Assim, ele promove vários encontros, as chamadas semanas catequéticas, para introduzir os novos princípios da Igreja renovada. Começa com o foco, a Igreja Católica passa de agora em diante a se chamar de Igreja dos pobres e dos pobres que caminham para a libertação.

A primeira coisa que acontece é o chamamento do Bispo. Todos são chamados para conversar com ele, mostrar-lhe sua realidade, seu sofrimento. A realidade do pobre é objeto, é foco, é motivo de reflexão. Não é mais um dado natural, é uma consequência de relações que são de opressão. Eles sabem bem disso, tinham direito a terra e tomaram, tinham direito a raiz, e Ihe tiraram, não tinha com quem reclamar sobre as injustiças que enfrentavam, agora tinham. Tinham um grande do lado deles.

Falar é dizer o que sente, confrontar com o que o outro sente e nesse diálogo, a percepção clara do que sente, do que sofre, do que passa. Isto porque diz para o outro, organiza seus sentimentos, suas percepções, e ao organizá-las ele as está repensando e repensando a partir da fala do outro. Ele escuta o outro, ao escutar se coloca e se coloca de novo ao de novo ouvi-lo. O que pensa, o que fala, o que escuta, desse modo vai se ampliando e aprofundando dando-Ihe a verdadeira dimensão da realidade envolvente.

E o Bispo está lá. Conversando, falando, escutando. Uma das qualidades que os diversos interlocutores acentuaram na personalidade de D. Fragoso foi o saber escutar, esperar sua vez para falar, respeitar a opinião do outro, acatar a fala dos demais. A importância e o significado dessa presença é fundamental no processo de organização dos trabalhadores rurais da 
Diocese de Crateús. D. Fragoso com isso angaria simpatia, e claro, é cada vez mais motivo da raiva dos grandes que se sentem ameaçados por sua presença.

Pode-se minimizar sua presença, em nenhum momento provocou o repúdio à Lei, ao Estado de legalidade. Lembro que havia certos inconvenientes decorrentes da ilegalidade do Estado militar de então. Mas, o retorno à legalidade fez dele um dos mais fiéis promotores do respeito à Lei. Mas, sabia ele, que a observância da Lei, por si só, já era no Brasil uma subversão. A Lei, na maioria das vezes era instituída para calar o povo e não para ser cumprida, efetivada. Mesmo na Nova República, o cumprimento da Lei era e é uma subversão e ao ser uma subversão, revela o caráter humano da mesma, mais do que isso, revela o caráter de classe do Estado.

Como sabia caminhar D. Fragoso. Como sabia os limites e como aproveitálos em benefício dos mais pobres, como sabia atuar de acordo com as condições objetivas, se o homem é expulso, se as relações de trabalho são desumanas, se o preço dos produtos da terra, dos produtos dos pequenos produtores, não paga as despesas de produção, se a renda da terra é sufocante para quem trabalha, ele sabe onde interferir e usar a realidade para educar, abrir os olhos, conscientizar.

As CEBs são um primeiro momento, é a reunião daqueles que estão próximos fisicamente, socialmente e culturalmente, é o espaço que precisa ser usado como espaço da fala, do diálogo, do debate e da discussão. Nelas, as condições de vida dos trabalhadores rurais são discutidas, e discutidas a partir daquilo em que acreditam e que para eles tem credibilidade: a Bíblia. É a religião e a vida em consonância, conformando sujeitos capazes de lutar pelos direitos que lhes são negados, pelo trabalho e por vida.

Essa intermediação da Bíblia provoca outro tipo de inserção, uma inserção na Igreja renovando-a e ao mesmo tempo questionando o poder do padre e 
da hierarquia na definição do sagrado, do pecado, da salvação. São duas frentes que se colocam como enraizadas numa mesma realidade, sociedade e Igreja; realidade que oprime o homem que trabalha e por isso, questionáveis. As duas se imbricam e dominam o homem, precisam, portanto, serem igualmente focadas e questionadas para serem reformuladas e se transformarem em instrumentos de salvação, no outro mundo, e de libertação nesse mundo.

Nesse processo, não se pode negar que a Igreja de Crateús contribuiu para o surgimento de sujeitos, sujeitos de direito e sujeitos de história. As Comunidades agregaram, permitiram a fala, fizeram aparecer a política como prática normal e diária de todos aqueles que pretendem ser cidadãos. Através das CEBs e a partir delas, foram construídos outros instrumentos de participação como os sindicatos dos trabalhadores rurais. D. Fragoso tinha a percepção da importância da CEB e de suas limitações, como tinha a percepção da importância do sindicato e da Igreja como instrumentos de universalização das lutas.

A Igreja era uma instituição universal, como instituição, tinha interesse em permanecer viva e atuante, era necessário que as pessoas a vissem como necessária ao desenvolvimento da vida. Pertencer à Igreja é não estar só, é pertencer a um conjunto que, se tem diferenças internas, tem interesse em mantê-lo, pois assim mantém intacta a força que esse universo dispõe. Doimo (1995), como Comblin (1989), percebem essa característica da Igreja e conseguem ver que não há interesse da parte conservadora da Igreja de romper com os progressistas, pois, sem a força desse todo, a Igreja não significa para nenhuma das partes. Por isso, Doimo mostra que os movimentos sociais, os novos movimentos que ela analisou, conseguiram sobreviver e ser fortes graças a essa instituição que é a Igreja.

Comblin chama a atenção de D. Fragoso e de seus auxiliares para essa necessidade de manter o conjunto. Para ele, se D. Fragoso existiu e atuou em espaços como o de Crateús, é porque a Igreja como um todo tem um 
capital que the é vital, que lhe assegura a desenvoltura com a qual trabalha em Crateús. É interessante frisar que em nenhum momento, pelo menos os depoimentos não negam e alguns deles até afirmam, D. Fragoso impede a realização do culto e das práticas pastorais conforme a velha liturgia. Como ele mesmo afirma, os padres mais conservadores, na medida em que ele valoriza as novas práticas e as reforça, vão paulatinamente percebendo que o espaço de sua ação foi restringido. D. Fragoso e Pe. Eliésio afirmam em seus escritos que eles acabam se licenciando ou se transferindo para outras dioceses.

Com o pontificado de João Paulo II, a ação pastoral de D. Fragoso é cerceada, já não consegue se expandir da mesma forma. A primeira dificuldade é a formação dos padres. O seminário de Olinda, criado durante o arcebispado de D. Helder Câmara, com sua aposentadoria, é fechado pelo novo arcebispo. O Bispo de Crateús tenta resolver o problema da formação consonante Concílio Vaticano II e Medellim, a partir da vivência nas comunidades eclesiais, mas, infelizmente a formação dos padres não se esgota aí.

Depois, existe um contraponto teológico, já não existe a presença forte da Teologia da Libertação, o papa que respaldava o novo caminho da Igreja não estava mais vivo, os teólogos que respaldavam essa nova visão de Igreja eram perseguidos, silenciados e mesmo afastados da Igreja hierárquica. A presença coercitiva do novo Papa era um senão, que afastava pessoas e restringia a ação, isolando o Bispo.

Nas entrevistas que me foram cedidas por Pe. Maurízio e Pe. Machado, ficou claro a interação que D. Fragoso mantinha com outros bispos, ligados à Teologia da Libertação e organizadores de CEBs. Dentre esses bispos estavam D. Helder, D. Casaldáliga, D. Fernandes, nomes de peso que foram afastados ou coibidos em sua ação pastoral. Mas, enquanto puderam, reforçaram, mutuamente, a ação pastoral de cada um. 
Segundo os entrevistados, D Aloísio Lorscheider aprendera a respeitar o trabalho de D. Fragoso e o divulgava entre os outros bispos e padres do Ceará. Claro que essa ação do arcebispo de Fortaleza se não trazia simpatizantes, pelo menos coibia as ações que poderiam ser contrárias.

Com a saída de D. Fragoso e a vinda de um novo bispo alinhado com os conservadores, continuou o trabalho de CEBs, mas já não contava com o respaldo da Diocese, se os padres e leigos não eram perseguidos por seu trabalho na linha da libertação, não contavam mais com o apoio, com a segurança do apoio que a diocese dava.

Mas esse era um momento em que outros instrumentos de participação apareciam, construídos que foram pelas comunidades ou por pessoas ligadas a elas. São os sindicatos já estabelecidos, com representação e interagindo com os demais sindicatos, com a Federação e com a CONTAG. Ao falar sobre os sindicatos e seu processo de organização Luis Antonio, em entrevista já citada neste trabalho, afirma que os sindicatos dos municípios ligados à Diocese de Crateús, chegaram à FETRAECE através de Amorim, que fora presidente do sindicato de Tauá.

A presença de Amorim em Fortaleza possibilitou aos chamados autênticos do sindicalismo dos trabalhadores rurais do Ceará remodelar os sindicatos, mesmo aqueles tomados por pelegos. A partir de então, os sindicatos tiveram presença mais firme na articulação das lutas e nas reivindicações dos trabalhadores.

Não se pode desprezar a presença de membros das CEBs, principalmente as de Crateús, na fundação do Partido dos Trabalhadores. O PT nasceu no Ceará da mesma forma que nasceu a nível nacional: foram as CEBs e a Igreja Progressista, responsáveis inclusive pela forma nuclear de organização do PT quando este nasceu. Assim, mesmo havendo algumas discussões sobre a pertinência de criação do PT na área diocesana de Crateús, como nos informa Pe. Maurízio, alguns acreditavam que o PMDB 
seria suficiente para transitar com os pleitos dos trabalhadores daquela região. Acreditavam que o aparecimento do PT dividiria as esquerdas causando prejuízo ao processo de abertura feita pela base.

Mas, o Partido dos Trabalhadores se afirma em Crateús, muitos dos membros da CEBs e dirigentes dos sindicatos dos trabalhadores rurais acabam consolidando o partido através, inclusive, de suas candidaturas a vereadores, prefeitos e deputados. Não seria demais lembrar que Amorim foi candidato a deputado federal pelo PT, obtendo uma significativa votação em todo o estado do Ceará.

Ficou claro, ao longo do trabalho que ora concluo, que a presença da Igreja Progressista e das Comunidades Eclesiais de Base foi fundamental na organização dos trabalhadores do campo do Sertão de Crateús. Eles se perceberam como classe, na medida em que se viram iguais, as carências eram as mesmas, falta terra para plantar, a exploração do trabalho e o valor da renda paga pela terra eram presença constante na vida deles. Sabiam que os causadores de sua desdita eram os proprietários de terra, seus oponentes e antagonistas. Sabiam que não poderiam resolver o problema da terra sem expropriar os proprietários.

Essa percepção mudou a forma de atuar desses sujeitos, aliás, dessas pessoas que emergiram como sujeitos a partir da instalação da Diocese de Crateús. Até mesmo a forma de representação do real em toda sua riqueza foi possível, e somente foi possível, através da reunião que as Comunidades permitiram.

Se hoje a população de Crateús reclama das condições de trabalho, da maneira como as administrações que se sucedem tratam da coisa pública, a própria percepção do público, da política, da política partidária, ela deve ao processo educativo que se instalou com as Comunidades. O VER, o JULGAR e o AGIR da ação católica especializada, a contribuição de Paulo Freire, assumida por todos os que estiveram presentes nesse processo de 
construção de cidadania que foi a experiência de Crateús com D. Fragoso, que é a leitura a partir da realidade e das relações que se estabelecem nela, geraram um sujeito que ainda hoje atua e atua criticamente.

Não se pode aceitar sem uma análise mais ampla a afirmativa de que as CEBs recuaram, que elas diminuíram a sua presença direta, que elas, através dos seus membros, já não levantam tantas questões. As pessoas com as quais conversei dizem que elas continuam as mesmas, mas sua ação não flue apenas pelas CEBs. Hoje existem os sindicatos, os partidos de esquerda, as associações de bairro, as pastorais, vários canais de expressão, alguns mais apropriados que os outros para a ação política, mas todos como instrumentos de cidadania.

Não se pode negar que alguns percalços têm ocorrido ao longo da caminhada. Que alguns caminhantes acabaram por escapar da caminhada ou ir por outros caminhos. Mas, a percepção do caminho existe e ela tem balizado os instrumentos do fazer política nesse país. 


\section{BIBLIOGRAFIA}

ADRIANCE, Madeleine Cousineau. Terra prometida: as comunidades eclesiais de base e os conflitos rurais. São Paulo: Edições Paulinas, 1996.

ALBUQUERQUE, Ronald de F. e. Igreja, Sindicato e a Organização dos Trabalhadores.. Tese de Mestrado. Fortaleza, UFC. 1991. Datilo.

Uma História como outra Qualquer, In ver. A

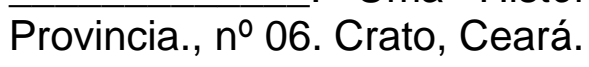

ALVES, Maria Helena Moreira. Estado e Oposição no Brasil (1964 1984). Petrópolis: Vozes, 1989

AMMANN, Safira Bezerra. Ideologia do desenvolvimento de comunidade no Brasil. 10.ed - São Paulo: Cortez, 2003

ARENDT, Hannah. A Promessa da Política. São Paulo: Difel, 2008.

BEOZZO, José Oscar. A Igreja do Brasil: de João XXIII a João Paulo II, de Medellín a Santo Domingo. Vozes, Petrópolis, R. Janeiro. 1996

BESERRA, Bernadete de Lourdes Ramos. Movimentos Sociais no Campo do Ceará (1950-1990). ESPLAT, Fortaleza, Ceará. 1990. Datilo.

BETO, Frei. O Que é Comunidade Eclesial de Base. Brasiliense, 1984 
BOFF, Clodovis. Comunidades Eclesiais de Base e Culturas. In. CEBs, cidadania e modernidade: uma análise crítica, Faustino L. C. Teixeira ... [et al.] - S. Paulo: Paulinas, 1993

Estatuto Eclesiológico das CEBs. In As $\overline{\text { Comunidades }}$ de Base em questão. Clodovis Boff ... [et al.] - S. Paulo, Paulinas, 1997

CALADO, Alder Júlio Ferreira. Participação progressiva dos cristãos, das religiosas e dos padres. In Fragoso, D. Antonio Batista [et al.]. S. Paulo: Edições Loyola, 2005

As Comunidades Eclesiais de Base. In

Fragoso, D. Antonio. Igreja de Crateús. Ed. Loyola, 2005

CALADO, Alder Júlio F; FRAGOSO, João da Cruz; GONÇALVES, Profeta dos Pobres, D. Fragoso nos Fala. As últimas entrevistas de D. Fragoso. Edições Buscas. João Pessoa 2007

CAMURÇA, Leinad. 25 anos de caminhada. Col. Fazendo a nossa história. Diocese de Crateús, 1989

COMBLIN, José. Cristãos rumo ao século XXI: São Paulo: Paulus, 1996.

COMBLIN, José e BOFF, Clodovis. Testemunho de Amigos. Col. Fazendo Nossa História. Diocese de Crateús, 1989

CRUZ, Dalcy da Silva. Sindicalismo Rural, Igreja e Partidos no Rio Grande do Norte, em 1960. In Movimentos Sociais: para além da dicotomia rural - urbano. Centro de Estudos e Pesquisas Josué de Castro. Recife, Pe. 1985, 11 ps. 
DOIMO, Ana Maria. A Vez e a Voz do Popular: Movimentos sociais e participação política no Brasil pós- 70. AMPOCS, Relume Dumará. R. de Janeiro. 1995

DUSSEL, Enrique. Teologia da Libertação: um panorama de seu desenvolvimento. Ed. Vozes, Petrópolis, R. Janeiro. 1999

ENGELS, Friedrich. Ludwig Feuerbach e o Fim da Filosofia Clássica Alemã. In Marx e Engels, Obras Completas. Vol. 3. São Paulo: Ed. Alfa-Omega Ltda, sem data.

FACÓ, Rui. Cangaceiros e Fanáticos. Civilização Brasileira e Ed. Universidade Federal do Ceará. 1980

FELTRAN, Gabriel de Santis. Desvelar a política na periferia: história de movimentos sociais em S. Paulo. S. Paulo: Associação Editorial Humanitas: Fapesp, 2005

FERNANDES, Bernado Mançano. MST, formação e territorialização. São Paulo: Hucitec, 1996.

FOLLMANN, José Ivo. Igreja, ideologia e classes sociais. Petrópolis: Vozes, 1985

FRAGOSO, Antônio. O Rosto de uma Igreja. Edições Loyola. São Paulo, 1982

FREI, Paulo, HORTON, Myles. O Caminho se Faz Caminhando, conversas sobre educação e mudança social. Ed. Vozes, Petrópolis, R. de Janeiro. 2003 
FRY, Karin A. Compreender Hannah Arendt. Petrópolis: Vozes, 2010

FUNDAÇÃO PADRE IBIAPINA. Diocese do Crato, 1981

GORENDER, Jacob. O Escravismo Colonial

HOORNAERT, Eduardo. Crônica das Casas de Caridade Fundadas pelo Pe. Ibiapina. Ed. Loyola. S. Paulo. 1981

IRISMAR. Fazendo a nossa História. Caderno 25 anos de história. Diocese de Crateús 1989

KADT, Emanuel de. Católicos Radicais no Brasil. Col. Educação para todos. UNESCO, MEC. Brasília, 2007

KOTSCHO, Ricardo. Paulo Freire, Frei Betto: essa escola chamada vida S. Paulo, Ed. Ática, 1986.

KOSIK, Karel. Dialética do concreto. S. Paulo: Paz e Terra, 1985.

LAFER, Celso. Hannah Arendt, pensamento, persuasão e poder. S. Paulo. Ed. Paz e Terra. 2003

LEAL, Victor Nunes. Coronelismo, enxada e voto. Ed. Alfa-ômega, 1986 
LÊNIN, V. I.. Que fazer? S. Paulo: Hucitec, 1979.

LESBAUPIN, Ivo. As comunidades de base e a transformação social. In Boff, Clodovis ...[et al]. As comunidades de base em questão. S. Paulo: Paulinas, 1997.

- Hegemonia neoliberal, democracia em declínio e reação da sociedade civil. In Lesbaupin, Ivo ... [et al.]. Petrópolis. Ed Vozes. 1996.

LIBÂNIO, João Batista e Oliveira, Pedro Ribeiro. Notas sobre o Momento Eclesial In: CEAS, n.120, março/abril de 1989.

LIBÂNIO, João Batista. Experiência da Igreja de Crateús. In: Fragoso, Antônio Batista [et al.] Igreja de Crateús: 1964 - 1998. S. Paulo: Edições Loyola, 2005

LÖWY, Michael. As aventuras de Karl Marx contra o Barão de Muchausen: marxismo e positivismo na sociologia do conhecimento. S. Paulo: Cortez Editora. 1994.

A Guerra dos Deuses, religião e política na América Latina. Petrópolis: Vozes, 2000

MADURO, Otto. Religião e luta de classes. 2.ed. Rio de Janeiro: Vozes, 1983.

MARTINS, José de Souza. A militarização da questão agrária no Brasil. Petrópolis: Vozes, 1984. 
- A Igreja face a política agrária do estado, In: Paiva, Vanilda e outros. A Igreja e a Questão Agrária. São Paulo: Loyola, 1985.

Não há terra Para Plantar Neste Verão: 0 cerco das terras indígenas e das terras de trabalho no renascimento político do campo. Petrópolis: Vozes, 1986 1995

Os Camponeses e a política no Brasil. Petrópolis: Vozes.

O Poder do atraso: ensaios de sociologia da história lenta. São Paulo: Hucitec, 1994.

. O Sujeito Oculto: ordem e transgressão na reforma agrária. Porto Alegre. Editora da UFRGS, 2003.

Reforma Agrária: O Impossível Diálogo. São Paulo: Editora da Universidade de S. Paulo, 2000.

MARTINS, Marcos Francisco. Marx, Gramsci e o conhecimento: ruptura ou continuidade?. Campinas,SP: Autores Associados; Americana, SP; Unisal, 2008

MARX, Karl e Engels, F. O manifesto do Partido Comunista. In Textos, Vol III. São Paulo: Editora Alfa-Omega, 1976.

O 18 brumário de Luís Bonaparte. In Textos, Vol. III. São Paulo: Ed. Alfa-Omega 1976. 
MENDONÇA, Sônia Regina de. A Grande Propriedade, Grandes Proprietários: velhas questões, novas abordagens. In Tamás Szmrecsányi (org.) História Econômica da Primeira República. Ed. Hucitec/Fapesp. S. Paulo 1996

MESTERS, Carlos. Testemunho de Amigos. Col. Fazendo a nossa História. Diocese de Crateús, 1989.

NOGUEIRA, Marco Aurélio. Em Defesa da Política. S. Paulo: Editora SENAC, 2001

NOVAES, Regina. Nada será como antes, entre urubus e papagaios. In: Teixeira, Fautino... [et al.] CEBs: cidadania e modernidade, uma análise crítica. S. Paulo: Edições Paulinas, 1993.

OLIVEIRA, Pedro A. Ribeiro de. Religião e Dominação de Classe: estrutura e função do catolicismo romanizado no Brasil. Vozes, Petrópolis, R. Janeiro. 1985

PARENTE, Josênio. Anauê, os Camisas Verdes no Poder. UFC. Fortaleza - Ceará

PAULA JOCA, Tereza Helena. A Agricultura no Semiárido do Ceará nos últimos 20 anos. In Diagnóstico Sócio-ambiental do Estado do Ceará, o olhar da sociedade civil. BNB. Fortaleza- Ceará. 1993

PERANI, Claudio. Notas para uma Pastoral Missionária. Cadernos do CEAS, n. 127, maio/junho de 1990, p.13-22.

Pastoral Popular e Movimentos Sociais: a evangelização e o conflito social no Brasil. Cadernos do CEAS, n. 126, Março/Abril, 1990 , p. $62-69$. 
Pastoral Popular e Movimentos Sociais. Caderno do CEAS, ํo 119. Janeiro/fevereiro de 1989

PIXLEY, Jorge e BOFF, Clodovis. Opção pelos Pobres. Petropólis, Vozes. 1986

PRESBURGUER, Miguel. ARAÚJO, Maria Tereza de. Notas sobre a Conjuntura Eclesial. Cadernos do CEAS, n.124, novembro/dezembro 1989, p. $42-54$.

RANCIÉRE, Jacques. O Desentendimento, Política e Filosofia. Ed. 34. 1996

ROLIM, Francisco Cartaxo. Religião e Classes Populares. Petrópolis: Vozes, 1980.

RODRIGUES, Leôncio Martins. Partidos e sindicatos. Escritos de sociologia política. São Paulo: Ática, 1990.

RICCI, Rudá. Terra de ninguém: representação sindical rural no Brasil. Campinas: editora da UNICAMP, 1999.

RICHARD, Pablo. A Igreja que Nasce do Povo na América Latina: Sua história, identidade e missão no movimento popular. in Caderno do CEAS, no 93 de 1984 ps 47 - 57

SADER, Eder. Quando novos personagens entraram em cena. S. Paulo: Ed. Paz e Terra, 1995. 
SANTOS, Boaventura de Sousa. Os Processos de Globalização. In Boaventura de Sousa Santos (org). Editora Cortez, São Paulo, S. Paulo. 2005

SANTOS, Eliésio dos. 25 ANOS DE CAMINHADA. Col. Fazendo Nossa História, ํㅡㅇ. 01. Diocese de Crateús

SOUZA, Luiz Alberto Gómez. JUC: os estudantes católicos e a política. Petrópolis: Vozes, 1984.

TELLES, Vera da Silva. Direitos sociais: afinal do que se trata. Belo Horizonte: Editora da UFMG, 1999.

THOMPSON, E. P. As Peculiaridades dos Ingleses e Outros Artigos. Campinas, São Paulo. Editora da UNICAMP. 2007, p.143

A Formação da Classe Operária Inglesa, a arvora da liberdade. Vol. I. Ed. Paz e Terra, R. de Janeiro. 1987.

TRONCA, Ítalo. Revolução de 1930, a dominação oculta. Brasiliense, S. Paulo. 1983

WANDERLEY, Luiz Eduardo. Democracia e Igreja Popular. S. Paulo: EDUC, 2007

VÁZQUEZ, Adolfo Sánchez. Filosofia da Praxis. Rio de Janeiro: Paz e Terra, 1968.

VIANNA, Werneck. Liberalismo e Sindicato no Brasil. R. de Janeiro. Paz e Terra. 1978 
VIGARANI, Ana. Vinte anos de caminhada, № 12. Col. Fazendo nossa história. Diocese de Crateús, 1989 


\section{APÊNDICE}

\section{LISTA ENTREVISTADOS:}

1. Eunice, assentada e dirigente sindical de Crateús

2. Manuel, trabalhador rural, professor do campo e dirigente sindical em Crateús

3. Ariosvaldo, trabalhador rural, professor do campo e dirigente sindical em Crateús

4. Seu Enoque, diretor do sindicato dos trabalhadores rurais de Crateús

5. Seu Luis Antonio, ex-dirigente do sindicato de Ipueira e da FETRAECE

6. Dona Maria de Jesus, Ex-coordenadora das CEBs, ex-Diretora do Sindicato dos Trabalhadores Rurais de Crateús e hoje ainda sindicalizada

7. Francisquinha, assentada do Assentamento de Palmares I, membro de CEBs, ocupante e acampada do Palmares

8. Flávio, professor e assentado no Palmares I

9. Antonio Gomes, assentado no Palmares I

10. José Alves, assentado no Palmares, fez parte do MST

11. Pe. Maurízio, vigário de Tauá, coordenador de CEBs

12. Pe. Machado, vigário de Independência e coordenador pedagógico da Escola Família Agrícola D. Fragoso de Independência

13.Pe. Osmar, vigário em Ipueiras, ex-assessor pedagógico da FETRAECE, delegacia do Cariri

14.Pe. Elênio, padre na Igreja de $\mathrm{S}$. Vicente de Crateús, um dos colaboradores mais antigos de D. Fragoso

15. Pe. Eliésio, colaborador de D. Fragoso e vigário de Ipueiras, falecido este ano de 2012

16. Pastora, assentada do D. Fragoso em Crateús

17. Rosali, membro da direção do Instituto D. Fragoso

18. Ivânia, membro da direção do Instituto D. Fragoso

19.D. Nenen, membro do Instituto $D$. Fragoso e membro ativa das CEBs

20. Tchesca, professora e membro da direção do sindicato dos professores de Crateús 